\title{
Civil Society and International Governance
}

The role of non-state actors in global and regional regulatory frameworks

\section{Edited by \\ David Armstrong, Valeria Bello, Julie Gilson and Debora Spini}

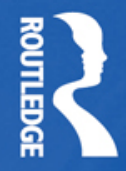

Routledge/GARNET Series: Europe in the World 


\section{Civil Society and International Governance}

Structures and processes occurring within and between states are no longer the only - or even the most important - determinants of those political, economic and social developments and dynamics that shape the modern world. Many issues, including the environment, health, crime, drugs, migration and terrorism, can no longer be contained within national boundaries. As a result, it is not always possible to identify the loci for authority and legitimacy, and the role of governments has been called into question.

This book critically analyses the increasing impact of nongovernmental organizations and civil society on global and regional governance. Written from the standpoint of advocates of civil society and addressing the role of civil society in relation to the UN, the IMF, the G8 and the WTO, the contributors to this volumes assess the role of various non-state actors from three perspectives: theoretical aspects, civil society interaction with the European Union and civil society and regional governance outside Europe, specifically Africa, East Asia and the Middle East. It demonstrates that civil society's role has been more complex than one defined in terms, essentially, of resistance and includes actual participation in governance as well as multi-faceted contributions to legitimizing and democratizing global and regional governance.

This book will be of interest to students and scholars of political science, international relations, civil society, sociology, European politics and global governance.

David Armstrong is Emeritus Professor at the University of Exeter. Valeria Bello is Marie Curie Intra-European Research Fellow at the Institut Barcelona d'Estudis Internacionals, Spain. Julie Gilson is a senior lecturer in the Department of Political Science and International Studies at the University of Birmingham. Debora Spini teaches political theory at Syracuse University in Florence and Social Philosophy at Florence University. 


\title{
Routledge/GARNET series: Europe in the world
}

\author{
Edited by David Armstrong
}

University of Exeter, $U K$

and

\section{Karoline Postel-Vinay}

Centre for International Studies and Research (CERI), France.

Editorial Board: Dr Mary Farrell, Sciences Po, Paris; Dr Karoline PostelVinay, CERI, France; Professor Richard Higgott, University of Warwick, UK; Dr Christian Lequesne, CERI, France; and Professor Thomas Risse, Free University Berlin, Germany.

International Advisory Committee: Dr Salma Bava, Jawaharlal Nehru University, New Delhi, India; Dr Knud Erik Jørgensen, University of Aarhus, Denmark; Professor Sunil Khilnani, SAIS, Johns Hopkins University, USA; Dr Anne-Marie Legloannec, CERI, France; Dr Xiaobo Lu, SIPA, Columbia University; Professor James Mittelman, University of Washington, USA; Dr Karen Smith, London School of Economics, UK; Professor Elzbieta Stadtmuller, University of Wroclaw, Poland.

The Routledge GARNET series, Europe in the World, provides a forum for innovative research and current debates emanating from the research community within the GARNET Network of Excellence. GARNET is a Europe-wide network of 43 research institutions and scholars working collectively on questions around the theme of 'Global Governance, Regionalisation and Regulation: The Role of the EU', and funded by the European Commission under the 6th Framework Programme for Research.

\section{EU Foreign Policy in a Globalized World}

Normative power and social preferences

Edited by Zaki Laïdi

\section{The Search for a European Identity}

Values, policies and legitimacy of the European Union

Edited by Furio Cerutti and Sonia Lucarelli

\section{The European Union and the Social Dimension of Globalization}

How the EU influences the world

Edited by Jan Orbie and Lisa Tortell 
4 Governance and the Depoliticisation of Development Edited by Wil Hout and Richard Robison

5 The European Union and International Organizations Knud Erik Jørgensen

6 The EU and Global Governance Edited by Mario Telò

7 External Perceptions of the European Union as a Global Actor Edited by Sonia Lucarelli and Lorenzo Fioramonti

8 A Global Security Triangle European, African and Asian interaction Edited by Valeria Bello and Belachew Gebrewold

9 European Union Democracy Aid

Supporting civil society in post-Apartheid South Africa Lorenzo Fioramonti

10 Civil Society and International Governance The role of non-state actors in global and regional regulatory frameworks Edited by David Armstrong, Valeria Bello, Julie Gilson and Debora Spini 



\section{Civil Society and International Governance The role of non-state actors in global and regional regulatory frameworks}

\section{Edited by David Armstrong, Valeria Bello, Julie Gilson and Debora Spini}

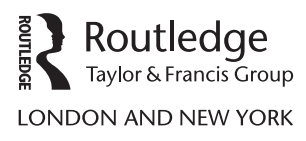


First published 2011

by Routledge

2 Park Square, Milton Park, Abingdon, Oxon OX14 4RN

Simultaneously published in the USA and Canada

by Routledge

270 Madison Avenue, New York, NY 10016

Routledge is an imprint of the Taylor \& Francis Group, an informa business

This edition published in the Taylor \& Francis e-Library, 2011.

To purchase your own copy of this or any of Taylor \& Francis or Routledge's collection of thousands of eBooks please go to www.eBookstore.tandf.co.uk.

(C) 2011 David Armstrong, Valeria Bello, Julie Gilson and Debora Spini for selection and editorial matter; individual contributors their contribution.

All rights reserved. No part of this book may be reprinted or reproduced or utilized in any form or by any electronic, mechanical, or other means, now known or hereafter invented, including photocopying and recording, or in any information storage or retrieval system, without permission in writing from the publishers.

British Library Cataloguing in Publication Data

A catalogue record for this book is available from the British Library

Library of Congress Cataloging in Publication Data

Civil society and international governance: the role of non-state actors in global and regional regulatory frameworks/edited by David Armstrong ... [et al.].

p. cm. - (Routledge/GARNET series: Europe in the world; 10)

Includes bibliographical references and index.

1. Regionalism (International organization) 2. Civil society. 3.

International cooperation. I. Armstrong, J. D. (James David), 1945-

JZ5330.C58 2010

$341.2-\mathrm{dc} 22$

ISBN 0-203-84005-4 Master e-book ISBN

ISBN13: 978-0-415-59063-1 (hbk)

ISBN13: 978-0-203-84005-4 (ebk) 


\section{Contents}

$\begin{array}{ll}\text { Notes on contributors } & \text { ix }\end{array}$

Introduction: civil society and international governance 1

DAVID ARMSTRONG AND JULIE GILSON

PART I

Theory

1 Civil society and the democratisation of global public space DEBORA SPINI

2 Collective and social identity: a theoretical analysis of the role of civil society in the construction of supra-national societies VALERIA BELLO

3 Organised civil society and political representation in the EU arena

\section{PART II}

The European Union

4 Europeanization of non-state actors: towards a framework for analysis

KAROLINA BOROŃSKA - HR YNIEWIECKA

5 Between localisation and Europeanisation: non-governmental organisations in Bosnia and Herzegovina 
viii Contents

6 European integration, cross-border cooperation and third sector mobilizations in the Basque Country

XABIER ITC AIN A

\section{PART III}

Civil society outside Europe

7 Governance and non-governmental organizations in East Asia: building region-wide coalitions

JULIE GILSON

8 Civil society in regional governance in Eastern and Southern Africa

ANDRÉAS GODSÄTER AND FREDRIK SÖDERBAUM

9 The role of civil society in regional governance in the Middle East

MICHAEL SCHULZ

10 Transnational labour mobilization in the Americas 


\section{Contributors}

David Armstrong is Emeritus Professor of International Relations of the University of Exeter, having previously held a Chair at the University of Durham and a Readership at the University of Birmingham. He has published widely on many aspects of International Relations, including Chinese foreign policy, international organisations and international law. His main books to date include Revolutionary Diplomacy: Chinese Foreign Policy and the United Front Doctrine (California University Press, 1977), The Rise of the International Organisation (Macmillan, 1982), Revolution and World Order (Clarendon Press, 1993) and International Law and International Relations (Cambridge University Press, 2007). He is a Fellow of the Royal Historical Society and previous editor of the Review of International Studies.

Valeria Bello has a PhD in Sociology and Political Sociology, and since November 2009 has been a Marie Curie Intra-European Fellow at the Institut Barcelona d'Estudis Internacionals (Spain). Prior to that, she had been a researcher at the Jean Monnet European Centre of the University of Trento (Italy). She has given courses at the University of Trento in the Sociology of International Relations and the Sociology of European Integration at both Bachelor and Master levels. Her research interests include: European identity, interethnic relations, the international relations of the EU, European civil society and regional governance. She is the editor of A Global Security Triangle. European, African and Asian Interaction (Routledge, 2010).

Karolina Borońska-Hryniewiecka is currently a PhD student at the University of Wrocław and a visiting researcher at the Deusto University in Bilbao. The title of her doctoral thesis is 'The evolution of regional participation in the European policy-making: the case of the Autonomous Community of the Basque Country'. Her areas of research include: regions and multi-level governance in the European Union; regionalisation and regionalism in Spain and the European Union; and lobbying and policy networks.

Julie Gilson is a Senior Lecturer in the Department of Political Science and International Studies at the University of Birmingham. Her research to date has focused on Japanese foreign policy, East Asian regionalism, and 
Asia-Europe relations, and her publications include Asia Meets Europe (Edward Elgar, 2002). Her current focus is on civil society in East Asia.

Andréas Godsäter is a $\mathrm{PhD}$ candidate in Peace and Development Research at the School of Global Studies, University of Gothenburg, and a visiting scholar at the Centre for the Study of Globalisation and Regionalisation at the University of Warwick. He is also a participating researcher in the international research programme International Democracy Watch, coordinated by the Centre for Studies on Federalism at the University of Turin. His research interests include regionalism, civil society and development cooperation with a special emphasis on Eastern and Southern Africa.

Xabier Itçaina is a CNRS research fellow in political science at SPIRITSciences Po Bordeaux (University of Bordeaux). His PhD thesis focused on the links between Catholicism and collective identity in the French and Spanish Basque Country. His current research is organised around three main themes: (a) Catholicism and polities in Southern Europe; (b) the territorial dynamics of social economy in Southern Europe; (c) political anthropology of identity politics in the Basque Country.

His recent publications include: 'Between Mediation and Commitment. The Catholic Church and the Basque conflict', in J. Haynes (ed.), Religion and Politics in Europe, the Middle East and North Africa. Challenges to Citizenship, Secularisation and Democracy (Routledge, 2010); (ed.), Economie sociale, territoire et politique en Europe du Sud, special issue of Pôl Sud, revue de science politique de l'Europe méridionale, 2009, vol. 31 (2); Les Virtuoses de l'identité. Religion et politique en Pays Basque (Presses Universitaires de Rennes, 2007). More details on: http://spirit.sciencespobordeaux. fr/PagesCV/Itcaina\%20Xabier.htm.

Erica Panighello obtained her PhD in Sociology from the University of Florence in 2009. Her main fields of interest include: ethnic relationships, the role of civil society in conflict management, European Union enlargement and capacity-building policies. Before starting work on her $\mathrm{PhD}$ she worked in Kosovo for an Italian NGO, from April 2003 to December 2004, implementing a project aimed at promoting interethnic dialogue between Albanian, Serbian and Ashkali communities. After that, she was involved in a number of short-term missions in both Kosovo and Bosnia and Herzegovina.

Carlo Ruzza (MA SUNY, PhD Harvard) is Professor of Political Sociology at the University of Leicester where he teaches courses on civil society and ethnic relations. He previously taught at the University of Trento, the University of Essex and the University of Surrey and was a Jean Monnet Fellow at the European Institute of Florence. His research interests focus upon civil society, Europe and social movements, especially the peace movement, the environmental movement and ethno-nationalist movements, and on EUlevel public interest associations. He also works on populism and rightwing parties and movements. His book publications include Europe and 
Civil Society: Movement Coalitions and European Governance (Manchester University Press 2004, new edition 2007); and, co-authored with Stefano Fella, Reinventing the Italian Right (Routledge 2009). He also co-authored a book in Italian on the role of organized civil society in local development policy and a book on the interaction between tourist policy and environmental policy. He has co-edited two books with Vincent Della Sala: Governance and Civil Society: Policy Perspectives and Europe and Civil Society: Movement Coalitions and European Governance (2007; both published by Manchester University Press). He has also published books on environmental issues and sustainable local development. He has published several book chapters and articles in journals including the Journal of European Integration, Theory and Society, West European Politics, Policy and Society and Innovation. He has worked on several EU-funded projects on anti-discrimination, environmental sustainability, youth, health and education policy, on comparative study of migrant organizations and one on the role of organized civil society in ten EU countries.

Marcelo Saguier holds a $\mathrm{PhD}$ in Politics and International Studies from the University of Warwick, and MSc in International Relations from the London School of Economics and Political Science and a BA Honours in Philosophy from Queen's University at Kingston, Canada. He is a member of Argentina's National Science and Technology Research Council (CONICET) and works as an Associate Professor in the Department of International Relations at the Latin American School of Social Sciences (FLACSO) in Argentina. His areas of research interest include: global/regional trade governance; regionalism in South America; transnational social movements; resistance to neo-liberalism in Latin America; the politics of TNC regulation.

Michael Schulz is Associate Professor in Peace and Development Research at the School of Global Studies, University of Gothenburg, Sweden. His research interests include: conflict resolution in general, new regionalism and democracy in the Middle East (in particular the Palestinian self-governing areas and Jordan), nation and state building as well as ethno-religious politics in the Middle East. He has published widely on these topics, in particular on the Israel-Palestine conflict, with more recent publications including: (coedited with Philippe De Lombaerde) The EU and World Regionalism. The Makability of Regions in the 21st Century (London: Ashgate, 2009); Democratization and Civil Society in the Middle East: Case Studies of Palestinian Self-rule Areas and Iraqi Kurdistan (Sida and Centre for Middle East Studies, Göteborg University second revised edition 2006); 'The European Union as important (low-profile) actor in Israeli-Palestinian conflict?', in Valeria Bello and Belachew Gebrewold (eds), A Global Security Triangle, European, African and Asian Interaction (Routledge, 2009); 'EU's Conflict Resolution Intervention in the Israeli-Palestinian Conflict', in Karin Aggestam and Annika Björkdahl (eds), War and Peace in Transition. Changing Roles and Practices of External Actors (Nordic Academic Press, 2009). 
Fredrik Söderbaum is Associate Professor at the School of Global Studies, University of Gothenburg, and Senior Associate Research Fellow at the United Nations University-Comparative Regional Integration Studies (UNUCRIS), Bruges, Belgium. He has published widely on regionalism, interregionalism and Europe's external relations. His most recent books include European Union and the Global South (co-edited with Patrik Stålgren, Lynne Rienner, 2010); Afro-regions. The Dynamics of Cross-Border Regionalism in Africa (co-edited with Ian Taylor, Nordic Africa Institute, 2008), The EU as a Global Player: The Politics of Interregionalism (co-edited with Luk van Langenhove, Routledge, 2006). The Political Economy of Regionalism: The Case of Southern Africa (Palgrave Macmillan, 2004), and Theories of New Regionalism (co-edited with Tim Shaw, Palgrave Macmillan, 2003).

Debora Spini teaches Political Theory at Syracuse University in Florence and Social Philosophy at Florence University. Her recent publications include $L a$ società civile post nazionale (Meltemi, 2006) and, co-edited with A. Giuntini and P. Meucci, Parole per il mondo globale (ETS, 2008). Among various articles and chapters in edited volumes, the most recent are 'Varied worlds, plural societies' in Humana Mente (www.humanamente.eu/issue12.html) and 'European civil society, identity and legitimacy' in F. Cerutti and S. Lucavelli (eds), European Union: Identity and Legitimacy (Routledge, 2008). 


\title{
Introduction
}

\section{Civil society and international governance}

\author{
David Armstrong and Julie Gilson
}

International politics have rarely seemed as uncertain since the end of the Second World War as they appear today. The Cold War, despite the threats it carried, did at least bring a degree of predictability and even stability to world politics: the nuclear 'balance of terror' imposed increasing degrees of self-discipline and restraint on the superpowers, while their competition for influence brought an element of stability to numerous potential conflict zones. Until 1970 American economic power was also able to underpin the 1944 Bretton Woods global financial system. Today we face a far less predictable and stable global situation, with the world economy lurching from one crisis to another, security fears of a completely different kind from anything anticipated during the Cold War, the collapse to the point of ungovernability of some African countries and fears of catastrophic consequences arising from global warming over the next few decades.

Many would argue that these crises share one further dimension: they are crises in governance. They do not simply indicate difficult times, but, crucially, point to a failure in the collective management of these problems: a failure in 'governance'. This concept itself is not easy to define, and is taken here to denote rules, structures and processes providing some measure of regulation over specific areas of activity and working towards certain given objectives. Rules, structures and processes may be formal or informal. Governance should be distinguished from the term government, which may be defined as authority exercised by a recognized agency over a given community backed by extensive powers of revenue generation and enforcement.

Particularly in international affairs, the structures associated with governance tend not to be based on coercive enforcement powers, and to retain relatively fewer powers to generate revenue. However, as will be illustrated throughout this book, many of the elements inherent in the two terms can overlap, and some observers would query whether the distinction between governance and government is indeed necessary or valid. In their contribution to this volume, for example, Godsäter and Söderbaum make use of an understanding of governance advanced by James Rosenau in which 'the exercise of control' is a key ingredient, rather than the preferred (and softer) term employed here: 'regulation'. Rosenau himself, however, is also very clear that 'governance' and 'government' are 


\section{D. Armstrong and J. Gilson}

separable phenomena: 'To presume the presence of governance without government is to conceive of functions that have to be performed in any viable human system irrespective of whether the system has evolved organizations and institutions explicitly charged with performing them' (Rosenau 1992: 3). In the two decades since Rosenau advanced that formulation the range of global activities and dynamics taking place outside a clearly demarcated 'governmental' space has escalated, notably as a consequence of various processes of 'globalization'.

This is a term that has provoked a vast and ever-growing literature in the last twenty years in many diverse academic fields and a correspondingly large range of definitions and controversies, which we cannot consider here. However, if there is a common core to this literature it is the assertion that structures and processes occurring within and between states are no longer the only - or even the most important - determinants of those political, economic and social developments and dynamics that shape the modern world. As Armstrong (1998) has suggested elsewhere, the term 'globalization' has been applied to processes (especially the expansion and internationalization of financial markets), interactive networks (such as global corporate management and world-wide epistemic and interpretative communities including Islam), structures (e.g. newly emerging power relationships deriving from changing global investment patterns), and discourses (e.g. new social constructions of cognition, identity and meaning built upon postmodern global conditions). Bello's chapter examines the issues of collective and social identity in the context of the EU.

As we have indicated, it is the many and varied consequences of globalization that present some of the most profound challenges to governance. Many issues, especially the environment, health, crime, drugs, migration and terrorism, can no longer be contained within national boundaries. As a result, it is not always possible to identify the loci for authority and legitimacy, and the role of governments per se has been called into question. As we discuss throughout this book, many different kinds of non-state actors, ranging from transnational corporations to terrorist networks, have emerged alongside such developments. The size, speed and power of global financial markets have grown to a point where even several governments acting in concert cannot control them. Governments in the age of the internet are equally unable to control the flow of information within their borders. Similar processes undermine the claim of the state to be the territorial location of the 'national society' and the repository of its distinct culture, language, values, symbols, rituals, practices and institutions. Finally, postmodernist readings of globalization argue that an even more profound paradigm shift is under way, as globalization undermines the dominant discourse of modernity and the Enlightenment as well as the state.

In the study of international relations the term 'governance' is used in three broad contexts. First, international governance corresponds to a situation in which the principal actors are states and the objectives relate mainly to the regulation of interstate relations. States have been careful to enshrine state sovereignty as the fundamental principle underlying any international organizations set up by them, including the United Nations, the International Monetary Fund 
(IMF) and the World Bank. Second, global governance involves state, intergovernmental and non-state actors and processes. Its objectives are more complex than those of international governance since it is concerned with the regulation of broad areas of interaction involving this wide range of actors. For example, the recent global financial crisis has involved interstate groupings, notably the Group of 20, but also more informal networks of advisers and regulators, international institutions like the IMF and World Bank, the banks themselves and other non-state actors, such as financial speculators and numerous individual states (sometimes at cross-purposes with each other). Moreover, processes of governance in the age of globalization include not just regulatory mechanisms of various kinds but the workings of that vast, invisible set of forces known as 'the market'. Third, regional governance may be seen as a subset of global governance. It involves diverse state, interstate and non-state actors and processes, but is applicable to a specific region.

Governance of any kind tends to be assessed by virtue of its effectiveness and legitimacy. Unlike the case for government, the effectiveness of governance structures cannot be measured by elections or other measures of popular approval. Rather, in the international/global context, effectiveness may be defined as the capacity to achieve a set of objectives without undue disruption. This, of course, is essentially a bureaucratic or administrative understanding of effectiveness as against the more democratic criteria employed in the evaluation of national government. While some might see such an understanding as appropriate in the context of intergovernmental organizations, it is much harder to comprehend legitimacy in any context without bringing in some kind of democratic input. Legitimacy may be understood in terms of a broad degree of acceptance by those directly affected by governance, but this immediately raises the question of how such acceptance is expressed and measured in the absence of conventional democratic means such as elections. How, in other words, can international governance be accountable, to introduce another key element in the general understanding of what legitimacy entails? Ebrahim and Weisband suggest that the term 'accountability' contains within it four facets: transparency, so that information is made available for public scrutiny; justification, or making sure that institutional leaders give clear reasons for their actions; compliance or monitoring and evaluating actions taken; and enforcement, or sanctions in the event that actions are not taken as promised or required (Ebrahim and Weisband 2007: 2-4).

The crisis in global governance is apparent in respect of both effectiveness and legitimacy. It can also be seen to span at least three sets of issues: security, the environment, and economics and finance. Our concern here is primarily with legitimacy (as we will focus on non-state responses), although questions relating to effectiveness are also considered. In recent times the most controversial issue in which the notion of 'international legitimacy' was frequently invoked was the American-led invasion of Iraq, where arguments focused on the lack of a Security Council resolution authorizing the invasion. In that context the assertion of the key policy makers involved was in essence that legitimate international 
governance consisted of acting in accordance with the UN Charter, which required Security Council approval of the use of force. However, the debate about international legitimacy has ranged far beyond this relatively narrow, legalistic conception, and has revolved around two interrelated arguments: that legitimate international, regional or global governance derives from clear evidence of popular approval and from a broad acceptance of the fairness of any act of governance.

It should be noted that this legitimacy crisis affects the individual state as well as global institutions. The state's claim to sovereign authority over a clearly demarcated territorial domain rests in part upon its claim to be able to provide various collective goods, notably security against external threats, internal law and order and some measure of economic welfare and social justice. Globalization has made it ever more difficult for states to live up to this claim, not simply in terms of their power to determine economic growth but also in their capacity to provide distributive justice when the competition among states for international investment obliges them to cut taxes of the wealthy in their endeavour to attract investment. Indeed many would argue that one consequence of globalization, both within and between states, has been an increase in economic inequality; bringing into question the argument that a key facet of legitimate governance is its perceived ability to provide outcomes generally accepted as fair.

It is at this point that the next key concept employed in this book comes into the picture: civil society. As with all of the terms used here, we are not attempting to impose any single definition, since all of them refer to phenomena of considerable complexity. That is certainly the case with civil society. The concept was first employed in a systematic way by John Locke ([1690] 1953, quoted in Armstrong et al. 2004), who referred to an association based on the rule of law and formed by men in a state of nature to protect their property, which he saw as consisting of life and liberty as well as 'estate'. Locke envisaged civil society as a force standing in opposition to oppressive state power, a usage it has continued to have to the present day, notwithstanding Marx's equation of civil society with 'bourgeois society', or the social relations emanating from capitalism. A fairly broad but useful definition is provided by David Held (1993: 6): 'Civil society constitutes those areas of social life - the domestic world, the economic sphere, cultural activities and political interaction - which are organized by private or voluntary arrangements between individuals and groups outside the direct control of the state.'

In recent times the term 'civil society' came to prominence in the struggles of the 1970s and 1980s against the repressive state machinery in Eastern Europe. At that time civil society was defined primarily as the antithesis of the totalitarian conception of the state as the single institution possessing legitimate authority. In other words, it was defined in terms of what it was not: not central but dispersed; not hierarchically or vertically organized, but horizontally structured (or indeed completely unstructured); not official but private and voluntary. It was not despotic or controlling or part of the power structure. It was rather the myriad small - and in some cases not so small - groups, organizations, associ- 
ations, agencies and networks that maintained social order, and which kept society working at the grassroots level. As such it was, of course, seen largely as a good thing. And as such, like other 'good words', it came to be appropriated by all sorts of other groups. For example, civil society (normally in the form of various social movements) came to be heralded as the antithesis not just of the state but of capitalism and of the whole politico-economic order, as in the case of the demonstrations against the World Trade Organization (WTO) or the IMF. In contrast, proponents of the so-called Third Way, like Tony Blair, Bill Clinton and European social democrats, also embraced the idea of civil society. The Thatcher-Reagan era had seemed to demonstrate the limits of rule by the national government, particularly in an age of globalization, and the advocacy by Third Way theorists of a strengthened civil society - sometimes under the label of 'communitarianism' - seemed to offer a way forward that would preserve social cohesion and domestic order. Thus, some governments as well as reformers and radicals had begun to promote the idea of civil society, with the inevitable consequence that the term has become increasingly malleable and rather fuzzy. Spini's chapter in this volume considers the historical and philosophical evolution of the term from the eighteenth century, while also problematizing some of the claims made for civil society's role in the postmodern era. Godsäter and Söderbaum distinguish between different roles played by civil society in global and regional governance: as partner, legitimator, site of resistance and manipulator.

One argument that has been made with increasing force in recent years is that civil society plays a crucial role in both the legitimacy and the effectiveness of global/regional governance (identified earlier as the two criteria by which governance tends to be evaluated). Ebrahim and Weisband (2007) suggest that advocacy groups of the kind we are considering here have a crucial role to play in global accountability. They expose publicly areas in which transparency is not forthcoming, appeal directly to leaders to explain the reasons for their actions, publish - now in a wide variety of communication channels - and disseminate information regarding areas where compliance has not been achieved. In addition, although sanctions of the kind employed in national contexts may be unavailable, they may exercise some measure of enforcement through such means as gaining public support for petitions, boycotts and other forms of popular action against decisions taken by the powerful. A central contention here is that specific transnational issues such as the environment, trade or finance give rise to specific transnational constituencies of affected groups and individuals who can no longer be defined in terms of traditional democratic notions of universal suffrage within a determinate territory. Democratic legitimacy in such circumstances may derive less from having directly elected representatives in each issue area than from the more varied activities of the many non-governmental organizations (NGOs), global networks and social movements that constitute 'global civil society'. Furthermore, because such activists are engaged in ongoing and sometimes expert, or at least knowledgeable, participation in their input into governance, they may be seen as an improvement on traditional, formal 
democratic methods. For instance, the Commission on Global Governance (1995: 257-260) called for the establishment of a Forum of Civil Society, which it saw as more likely to meet the need not just for greater public participation in governance, but for more genuine participation than the more traditionally grounded idea of a world assembly of parliamentarians. Some academic observers have also seen global civil society's capacity to mobilize public opinion behind specific agendas as offering a more authentic, less hierarchical basis for democratic legitimation than frequently discredited governments. Non-state actors often enjoy closer and more intimate access to local levels of public opinion, while many contemporary issues, which are 'long-range, open-ended and diffuse in their need for attention', are not always susceptible to resolution through traditional, centralized modes of decision making (Ku 1995: 142-143). As well as their democratic role, civil society activists also argue that, as individuals committed to the pursuit of justice in various domains, they also meet the second main requirement of legitimate governance: its enhancement of fairness. Moreover, they claim to be able to add to the effectiveness of governance by virtue of their ability to make things happen at grassroots levels and their capacity to act in more imaginative and flexible and less bureaucratic ways than traditional public services. Assertions of this kind have been central in meetings of global civil society representatives, as a paper written for a meeting in Manila of more than eighty NGO networks demonstrates:

In the long run we have to invent the infrastructure so citizens can participate effectively in the democratic management of the global system. In the next decade, NGOs and their networks are one of the important precursors of an accountable global civil society. They are one of the few actors who try to articulate the global public interest.

(Callahan 1999)

One additional complicating factor in discussion of civil society and governance is that the dominant narratives and conceptualizations tend to reflect a Western-centric perspective, normally including a specific Western understanding of democracy and the ways in which democracy may be enhanced. As the third part of this volume illustrates, there are active 'civil societies' in nonWestern states, but their premises and objectives may be quite different from those seeking democratic change. What this implies is that, however civil society is defined, it has to be understood within its own historical trajectory and studied within specific socio-cultural and political contexts.

There are, of course, many objections that may be made to the kinds of democracy-enhancing claims advanced by activists. Even where civil society associations may genuinely represent some issue of broad international concern, they themselves are not always perfect models of democratic control or transparency. Jan Aart Scholte (1999) has pointed to several potential defects in this respect, including limited opportunities for members of an NGO to participate in its affairs, and opaque financial and decision-making procedures. Indeed, in 
many instances NGOs - particularly in their contemporary professionalized forms - cannot be said to represent directly the grassroots communities they purport to stand for. Where international and regional governance agencies do make a point of consulting civil society representatives, this may stem from motives other than a desire for greater democracy; they may even stem from a more cynical desire to deflect criticism (Parks 2004).

One further criticism is that some activists may prefer the 'gesture politics' of holding parallel conferences alongside WTO meetings, for example, rather than engaging in the duller task of attempting to influence the wording of some specific clause in an environmental treaty (Speth 1992). This last, however, is a more complicated issue than it may appear at first sight because many NGOs do not always gain access to official channels, so many parallel conferences have been organized with the deliberate purpose of publicly raising issues that may only be on the periphery of the 'main event'. It is also the case that global institutions that do admit civil society representatives tend to give access to an NGO 'elite', so that many smaller and less well-connected groups have no choice but to lobby independently. Similarly there is a risk that groups that cooperate and interact too closely with government officials may end up effectively co-opted into quasi-governmental functions. In the most famous example of this, the International Committee of the Red Cross (ICRC), whose role is officially acknowledged in numerous intergovernmental documents, it could be argued that it is only by accepting self-imposed constraints, including refraining in most cases from direct criticism of governments, that the ICRC has been able to carry out its crucial work during times of conflict. Other NGOs prefer to retain their independence and freedom to criticize governments. ${ }^{1}$ That, of course, does not make them immune from criticism. In a recent study of NGOs in international society, Volker Heins (2008), while broadly supportive of what these organizations seek to do, suggests several reasons for treating some of their more ambitious claims with caution, if not scepticism: their 'managerial liberalism', moralism and tendency to ignore local causes of Third World problems (which they often see as caused by Western imperialism and capitalism) may at times be over-simplistic and counter-productive.

In the chapters that follow, we consider the interaction between various kinds of non-state actors and international governance from three key theoretical perspectives and also in the context of the EU and in relation to regional governance outside Europe. Debora Spini opens our theoretical analysis by arguing that globalization has led to more profound changes than can be fitted into existing conceptual categories - including those most commonly employed with respect to civil society. After discussing two contrasting lines of thought in Western political philosophy relating to civil society, she suggests that, in a world characterized by a weakening of the capacity of the state to perform some of its traditional functions, alongside a reconfiguring of existing modes of state governance and the emergence of other political actors, orthodox views of civil society, which place it in a particular relationship to state power, need to be re-evaluated. In the 'profound transformations' taking place in the era of globalization and the 
'second modernity', a new global public space is emerging with many actors state and non-state - and this itself may be seen as an evolving form of governance. This in turn inevitably makes the true place of civil society far more ambiguous and elusive than is assumed by traditional analyses that separate it from and place it in opposition to those perceived to be the main holders of power since power itself has become a much more complex and multi-faceted phenomenon. Assumptions revolving around civil society's essentially democratic functions may not necessarily prove the most effective analytical tools to comprehend the role of civil society in the 'second modernity'.

In our second theoretical chapter, Bello's starting point is also the existence of a postmodern globalized world. Regionalism has been a significant response by states to the pressures of globalization but in its most developed form - the $\mathrm{EU}$ - serious problems have surfaced in recent years relating to the failure of EU citizens to see the EU as a key part of their collective identity. Bello's chapter is concerned with the possibilities and problems of social identity formation at the regional level - indeed whether such a form of identity is possible at all where the existence of strong national identities may actually perceive it as a threat. Her discussion draws upon the extensive literature relating to socialization and also the classic distinction between 'community' and 'society', where the former involves a sense of belonging and a shared understanding of meaning and values while the latter involves a more rational perception of common interests. Socialization processes - the acquisition of social learning of rules, meanings and values - are more crucial to any genuine formation of a community identity than top-down initiatives like the EU's promotion of common symbols like the EU flag and anthem. Here the role of various kinds of non-state actors may be vital in developing a horizontal rather than vertical dynamic of socialization. Bello cites the example of the 2008 protest where fishermen from several member states perceived a common interest and a shared identity. Bello's own earlier research has included in-depth interviews with Italian members of the EU's Economic and Social Committee, who emphasized the importance of being able to demonstrate a widely shared consensus to the more powerful EU Council and Parliament in their efforts to influence policy.

Carlo Ruzza focuses upon a third crucial aspect of civil society, especially in the EU context: representation. This has important theoretical and practical aspects. In particular, traditional concepts of representation employed by democratic theorists - for example in the context of national parliaments - need to be broadened, especially in relation to supranational institutions like the EU Commission. Here, 'their remoteness from specific constituencies makes the role of civil society as provider of alternative chains of representation particularly useful in terms of both top-down and bottom-up dynamics'. This is especially the case of groups that otherwise might be relatively disfranchised for various reasons but a much broader and more far-reaching set of changes is taking place that, in effect, are bringing civil society into an ever-closer role with regard to EU governance. Civil society, for example, has become increasingly important as a source of information but also in more clearly 'governmental' areas, such as 
service delivery, policy implementation and monitoring and in the emergence of the kind of 'soft law' steering mechanisms that characterize governance which lacks the coercive authority of the state. Here too crucial questions about the legitimacy of governance are increasingly apparent.

Our next section examines some specific aspects of civil society in the EU context. Karolina Borońska-Hryniewiecka elaborates a framework for analysing the interaction between non-state actors and the EU through the concept of 'Europeanization': the process by which various actors adapt to the reality of the EU and the associated emergence of new political dynamics. She suggests three possible perspectives on this crucial phenomenon. The neo-institutionalist 'rational choice' approach assumes that any fundamental institutional change involves a redistribution of resources among actors and she comprehensively evaluates the different factors affecting this process. The sociological perspective focuses rather on the ways in which the EU changes the logic of interaction among its various state and non-state actors, with new institutionalized consensuses emerging from the evolving understandings about meaning and values that flow from the existence of the EU. Finally, a historically grounded framework would stress, instead, that institutional change needs to be seen as a long, incremental process conditioned by different national experiences and cultural heritages.

Erica Panighello's chapter, drawing upon extensive empirical research, including interviews, examines the case of NGOs in Bosnia and Herzegovina. There the EU's greatest concern has been to aid in reducing the kind of ethnonationalism that brought so much violence in the 1990s and NGOs have come to be seen as playing a vital part in that enterprise. She argues that NGOs have become a sort of 'counter-elite' in Bosnia and Herzegovina, standing for more inclusive and non-discriminatory social values than, for example, those prevalent in some political parties. Their position in the country has its own unique complexities: their financial support from the international community sometimes enables them to offer higher salaries than state agencies, which obviously provides other motives for joining them than the more selfless idealism and activism that often characterize their counterparts elsewhere. But they are, nonetheless, seen by the EU Commission as 'ideal partners' in its aim of conveying its message about European values and helping to break down ethnic divisions.

The potentially ambivalent impact of Europeanization in a troubled border region is the concern of Xabier Itçaina's chapter on the Basque region. In this he employs a distinction drawn by O'Dowd and McCall between international relations, which are border confirming, and transnational relations, which are border transcending. In one sense, the increasingly close links between Basque civil society organizations on both sides of the border may be seen as border transcending. On the other hand, such civil society mobilization may sometimes see itself in competition with, if not in outright opposition to, cross-border cooperation policies that function on an inter-institutional basis. Therefore, these transnational thirdsector mobilizations possess an instrumental, rather than identity-based, relationship to European integration. Europe is grasped as an opportunity to go further in 
the institutionalization from below of a cross-border Basque common identity. Basque third sector actors are, indeed, developing a cross-border regional civil society, but this 'micro-regionalism' has to be understood in the light of the pursuit of very distinctive interests. As Itçaina's detailed research indicates, however, many special-interest NGOs and social movements such as farmers try to include their specific causes in wider transnational mobilizations at the European and international levels in order to gain international support. This creates an exceptionally complex relationship between local issues and international causes, civil society actors and multi-level institutional frameworks.

Our third section concentrates on civil society in four key regions outside Europe: East Asia, Eastern and Southern Africa, the Middle East and Latin America. As Julie Gilson's chapter on the first of these regions argues, while there is substantial debate within East Asia about the nature of civil society, there is little agreement as to what it might actually represent and signify in terms of government structures and democratization. Her main focus is on the nature and objectives of transnational advocacy networks in the region, including their two-way interaction with integration projects. After discussing in general terms some of the more important issues relating to such advocacy networks, including the challenges they pose to orthodox understandings of the state, she examines in detail the origins and organizational capacities of a number of East Asian networks, in particular Forum Asia and the Asian NGO Coalition for Agrarian Reform and Rural Development (ANGOC). She shows how these networks have evolved in the context of broader regional developments, drawing particular attention to some of the complexities and subtleties that make the East Asian experience so distinctive.

Andréas Godsäter and Fredrik Söderbaum follow Gilson, beginning with some general observations about the relative neglect of civil society in the academic study of regionalism. They also suggest that theories and conceptualizations of civil society rooted in the Western or European experience risk misunderstanding the logic of African civil society and its involvement in regional governance. For example, many Africanist scholars consider civil society to be conflictual and contradictory, arguing that the Western academic community tends to idealize civil society, conceptualizing it as homogenous and inherently democratic. They also point out that civil society actors may be involved in complex, rather than simple and straightforward, relationships with other types of actors, and this may blur the distinctions between civil society actors, states and private market actors. At the same time it is evident that external actors play an important role in the promotion of civil society in Africa, a more powerful role than that observed in Western civil society. In the course of an examination of civil society actors in two broad sectors (sustainable development and social and economic justice), they develop and apply a typology comprising four partly competing types of civil society participation in regional governance: partnership, legitimation, resistance and manipulation. Such divergences may lead to tensions between civil society actors but may also strengthen their involvement in regional governance. 
Michael Schulz's wide-ranging chapter considers the Middle East, a region which is simultaneously one of the most critical in contemporary world politics and, historically, least susceptible to both regionalism and a vibrant civil society. After considering claims that Islam is inherently incompatible with democracy and that many regimes in the region suppress civil society, he argues that several countries have in recent years engaged in different experiments with electoral practices, while Islamic and other organizations point to quite a strong democratic popular culture. Although these are unevenly distributed throughout the region, NGOs dealing with issues that are similar for the entire region have indirectly helped to 'regionalize' such issues. These include issues such as HIV/AIDS and gay rights that are taboo in many Arab states. In such cases, as well as region-wide issues such as water and climate change, civil society has been the key driving force. Like similar organizations in other developing world regions, Middle East NGOs frequently have strong links with global civil society: a source of both funds and criticisms of being too Western-orientated. Schulz concludes that Islamist and other social movements may help to create a new dynamic in the Middle East, helping to promote a more participatory and regionalist politics.

Finally, Marcelo Saguier asks whether shifting patterns of power associated with multiple levels of decision making and governance of trade are changing the dynamics of mobilization of the labour movement in Latin America. His starting point is that regionalization and globalization have posed various kinds of threat to the bargaining power of the labour movement. This is particularly the case of the unfolding process of the Free Trade Area of the Americas (FTAA), which he sees as creating a multi-faceted challenge to the labour movement to articulate alternative transnational strategies to 'the institutional, material and ideational power structures of neoliberal globalization'. This involves, among other requirements, mobilizing new multi-sectoral and transborder networks to confront regional governance institutions and influence the trade agreement's agenda, for example by broadening it to incorporate gender and human rights issues. In the course of this strategy, the labour movement has built coalitions with a wide range of other organizations. This in turn has not only helped to renew the labour movement itself but has led to the creation of alternative democratic spaces that have enlarged the regional agenda to include issues like indigenous and gender rights and environmental sustainability.

\section{Note}

1 For further discussion of this, see David Armstrong (1985).

\section{References}

Armstrong, D. (1985) 'The International Committee of the Red Cross and Political Prisoners', International Organization, Autumn, pp. 615-642.

_ (19988) 'Globalization and the Social State', Review of International Studies, vol. 24, 4, pp. 461-478. 
Armstrong, D., Lloyd, L. and Redmond, J. (2004) International Organisation in World Politics. The Making of the Twentieth Century, 3rd edn, Basingstoke: Palgrave Macmillan.

Callahan, D. (1999) 'What Is Global Civil Society?', CivNet Journal, vol. 3, 1, JanuaryFebruary.

Commission on Global Governance (1995) Our Global Neighbourhood, Oxford: Oxford University Press.

Ebrahim, A. and Weisband, E. (2007) Global Accountabilities: globalism, pluralism and public ethics, Cambridge: Cambridge University Press.

Heins, V. (2008) Nongovernmental Organizations in International Society: struggles over recognition, New York: Palgrave Macmillan.

Held, D. (1993) Political Theory and the Modern State, Cambridge: Polity Press.

$\mathrm{Ku}, \mathrm{C}$. (1995) 'The Developing Role of NGOs in Global Policy and Lawmaking', in Chinese Yearbook of International Law 1994-5, Taiwan: China Books and Periodicals.

Locke, J. [1690] (1953) Two Treatises of Civil Government, London: J. M. Dent \& Sons.

Parks, S. (2004) 'How Transnational Advocacy Networks Reconstitute IO Identities', Seton Hall Journal of International Relations and Diplomacy, vol. 5, 2, pp. 79-93.

Rosenau, J. N. (1992) 'Governance, Order, and Change in World Politics', in Rosenau, J. N. and Czempiel, E. O. (eds) Governance without Government: order and change in world politics, Cambridge: Cambridge University Press.

Scholte, J. A. (1999) 'Global Civil Society: Changing the World', Warwick University Centre for the Study of Globalisation and Regionalisation, Working Paper no. 31/99, May.

Speth, J. G. (1992) 'A Post-Rio Compact', Foreign Policy, 88, Fall, pp. 145-161. 
Part I

Theory 



\title{
1 Civil society and the democratisation of global public space
}

\author{
Debora Spini
}

\section{Introduction}

Globalisation processes have made it necessary to conduct a general reassessment of the political vocabulary typical of Western modernity, and to reconsider categories such as those of state, borders, and territory. Among the conceptual tools of Western modernity, that of civil society has enjoyed renewed attention in recent decades, especially since the momentous events of 1989. At present, civil society is widely recognised as a key actor in global governance, and a key factor for democratisation in both domestic politics and the still developing global public space (Armstrong et al. 2004; see Introduction in this volume).

This chapter focuses on the question of whether a stronger role for civil society in global governance would automatically translate into the democratisation of a post-national public space. Moving on from an analysis of the different models of civil society, the chapter will criticise some current assumptions about its role and function in a globalising world. It will then proceed to question the prevalent definition of global civil society as the whole of public interest groups or, in a narrower sense, all organisations sharing core values such as justice, a respect for difference, and human rights. This chapter argues that identifying civil society simply with the voice of the voiceless, or as the point of origin of communicative power, does not help to understand the profound transformations occurring in this second modernity. The chapter aims to defend the claim that civil society must be analysed not only as a space that needs to be protected from political power, but also as a space where new forms of power - not purely communicative - are developed and exercised, within the overall framework of postnational governance. For this reason, the chapter includes a short section on the specific functioning of civil society within the EU, as the European polity illustrates the processes of transforming democracy. It addresses the question of how civil society interacts with the new forms of political and social power that are typical of the second modernity, and whether it may be conducive to a sort of post-democratic governance rather than to a genuine democratisation of postnational spaces. 


\section{Models in Western political thought}

An immense literature has developed on the theme of global civil society. In most cases, such a literature identifies global civil society as a galaxy of groups and networks involved in struggles for global justice, sustainability, the empowerment of women, respect for human rights, and so on - in short, the same kind of movements that take part in global fora (Falk 1995). Contemporary scholarly literature - and to a certain extent political communication as well - privileges a definition inspired by Habermas or Cohen and Arato, whereby civil society is the space were questions of public interest are discussed by individuals or groups organised on a voluntary basis; often, civil society is considered to equate to NGOs or non-state actors (Cohen and Arato 1992; Falk 1995; Habermas 1991, 1996). One remarkable exception is represented by the concept developed by EU official documents, which focus on civil society as the totality of interest groups because they reflect the unique experience of European governance.

These prevailing definitions can be challenged in terms of both their capacity to describe what is actually happening and their normative value. They do not help us to understand in all its complexity the transformation of a globalising political space, as they take into consideration only a part of the picture. The socalled global public space is inhabited by a great variety of different actors, many of whom are far from sharing those values of justice, toleration, and respect for difference. Therefore, it would be much more appropriate to use terms other than a generic reference to 'civil society' in order to define the galaxy of progressive, justice-oriented organisations: one example is the term 'alter-globalism' (Marchetti 2008). Moreover, the genealogy of civil society in Western modernity is extremely rich both in theoretical models and in concrete historical practices. Such richness should not be ignored, and some of its highlights may prove helpful for capturing many of the current transformations.

In the history of modern political thought, civil society has traditionally represented the middle ground between private life and an exclusively political space, more specifically the level of the 'state' and of 'government'. The very existence of a separate sphere between that of family and intimacy on the one hand, and that of government and state power on the other, can indeed be considered a marked feature of Western modernity itself. Nonetheless, the separation between society and politics did not surface instantaneously. At the dawn of modern political thought, 'civil society' coincided completely with political society, as in Hobbes, who does not see any space of 'society' before or outside the space made peaceful by the action of the Sovereign. One of the earlier notions of a 'society' as a separate sphere of social interaction, and existing apart from and before the covenant establishing a political society in its proper sense, appears in Locke. The Second Treatise on Government suggests that even before the existence of a properly political society, men were involved in commercial and economic relations, which were in themselves constitutive of social bonds. The Letter concerning Toleration also demonstrated how men join together to pursue a great variety of activities, such as providing for the salvation of their 
souls by performing different forms of worship. From this perspective, the political covenant establishing 'government' exists in order to protect such a sphere, but does not create it, thus marking a major difference with the Hobbesian model. Furthermore, moral and political philosophers of the eighteenth century, such as Smith and Ferguson, also gave shape to a specific sphere of interactions which are not 'political' per se and yet which may be considered as the foundation of social, and consequently also of political, bonds. In contrast, throughout late eighteenth- and nineteenth-century political thought, the need to protect and preserve an autonomous space for society, as opposed to the potentially oppressive power of the state, became one of the key themes of classical liberalism, which would serve to formulate the relationship between state and civil society in terms of zero-sum opposition towards each other.

This survey of theoretical models is brief, but two main genealogical lines may be understood. The first, focused on the line that unites the Scottish Enlightenment to the Hegelian-Marxian perspective, assigns a primary role to the interplay of passion and interests as well as to the social genesis of needs. Consequently, this genealogy highlights the essentially conflictual character of the relationships defining civil society and ends by connecting it to the sphere of the economy. The second model stretches from the experience of the Enlightenment to include fully fledged liberal theories: it privileges, instead, the role of civil society as the source of democratic legitimacy, and gives a minor role, if any at all, to the sphere of economic activity.

Hegel represents a pivotal step in the first genealogical line. His conceptualisation of civil society in Philosophie des Rechts deserves special attention not solely for historical reconstruction, but also for the new light it may cast on the present context. Civil society is the second term of Hegel's political trilogy, besides family and the state; it represents the 'system of needs', the space where needs are first created through social interactions and then satisfied through the medium of work and of economic activity. It is not superfluous to underline that Hegel's civil society is bürgerliche, not zivil; individuals take part in it as private actors, moved by their often selfish needs and interests. It is a space where individuals establish social bodies for the pursuit of particular interests. Such groups are collective - yet not universal - and are likely to be in competition, even in open conflict, with one another. Hegel's Bürgerlichegesellschaft, although essentially conflictual, is something more than the mere battlefield of selfish drives. In civil society, men ${ }^{1}$ join together to form corporations (Stände): these are social groupings primarily defined by their position in the chain of economic activity, focused on the defence of specific interests and, therefore, always potentially in conflict with their peers. Nonetheless, these associations are more than the sum of individual egos; they are the space where individuals can - and must - learn to think and behave as a body. Moreover, Hegel highlights how corporations cannot avoid meeting their own peers in the open arena of civil society, thus being forced to overcome their self-centred perspectives. This encounter among corporations, although necessarily marked by conflict and competition, represents an essential step, because every corporation - and the individual members 
within it - needs to be reconciled with the whole body of the state through the medium of Law (Recht). Mediating potential and especially actual conflicts, and leading opposed interests to a general aim, is the function of Recht. Civil society is necessarily marked by conflict, and therefore it needs the state to outgrow its original nature. Only the state, as the source of normativity, may transform bürgern into proper citizens, capable of thinking and acting in universal terms.

Marx's conception placed even greater emphasis on the conflictual nature of civil society, defined as the whole of material relationships among individuals, and, consequently, as a space overlapping to a good degree with that of the market. Marx's critique was directed at the Hegelian dichotomy between membership of civil society and citizenship. He defined this dichotomy as a schizophrenia typical of the bourgeois state, which revolves around the artificial juxtaposition of homme, defined by interests and needs, and citoyen, supposedly open to the dimension of universality. Marx's Bürgerlichegesellschaft, therefore, basically coincides with the market, and is to be interpreted strictly according to the instruments of dialectic materialism. But whereas in Marx it is entirely defined by political economy, in the Gramscian perspective civil society is endowed with a higher degree of autonomy, as it provides the arena for a struggle over cultural influence and hegemony that goes beyond a strict opposition between structure and superstructure.

Gramsci's thought has recently been rediscovered and reapplied in analyses of globalisation, and also applied to the specific condition of civil society within that framework (Cox 2002; Baker and Chandler 2005). This attention to civil society as a transmission mechanism for dominant mental frameworks was previously developed, although in a different light, by Foucault. He highlighted the ways in which civil society as a category responds to a compelling need for liberal gouvernementalité. From this perspective, civil society makes it possible to rule as a sovereign over a space populated by homines oeconomici. It is therefore an integral part of the governmental technology of the liberal state, or, in strictly Foucauldian language, is a figure de transaction, creating an interface between rulers and ruled. Civil society somehow escapes - or rather, it seems to escape - the governmental scope of control; yet it reinforces its capacity for domination, as it represents a specific governmental rationality based upon economic rationality. In this way, it is reminiscent of the specific role of folly (Foucault 2008).

The second genealogical line can be reconstructed around the focus of legitimacy and popular sovereignty. This itinerary stems from the République des Lettres of the late seventeenth and early eighteenth centuries and develops throughout Western modernity to embrace contemporary theories of democratic legitimacy. This model finds its turning point in Kant's concept of Publizität, and emphasises the exercise of reason by a public of 'reasonable' men $\left(\right.$ mostly! $\left.{ }^{2}\right)$; private individuals who, while not sharing any direct involvement with government, have nonetheless learned to think about and judge public affairs, and therefore develop a self-understanding as 'public opinion'. Civil society thus becomes the space where matters of common relevance may be 
debated and evaluated through the public use of reason; all deliberations formulated within a public discourse are thus determined by the strength of the most convincing arguments, rather than by the enforcement of sheer might. Consequently, public opinion becomes the ultimate tribunal for the validity of norms, and the ultimate source of political legitimacy. The classic liberal view is articulated by a long tradition of thought, from the Enlightenment to John Stuart Mill. Nonetheless, it is important to remark how civil society, if considered as the source of democratic legitimacy, needs to transform itself into something else; namely, to crystallise into systems of norms, or constitutional structures. Even more drastically, it may end up becoming the state itself. As indicated by Arendt in On Revolution, (1973) popular sovereignty, in order to guarantee freedom, has to abide by the self-imposed limits of a constitutional order.

Habermas can be considered as the culmination of this thinking, even though his reinterpretation of zivilgesellschaft as the cradle of legitimacy includes more distinctively republican elements than is the case with mainstream liberalism. In his Structural Transformations of the Public Sphere and even more in Between Facts and Norms (Habermas 1991, 1996), he describes civil society as the breeding ground where new issues and demands are formed, received and re-elaborated by the public sphere, and finally translated into policies and law-making norms, or in other terms into 'rights', by the political system, thus ensuring a substratum for that legitimate exercise of power which in Weberian terms could be defined as Herrschaft, as opposed to Macht. Moreover, from the perspective of deliberative democracy, civil society is the space where different subjects may also engage in communicative processes conducive to a level of agreement much higher than the strictly Rawlsian conception of overlapping consensus.

Although they can and must be separated as theoretical models, the two faces of civil society were, in their historical phenomenology, closely connected. First of all, the two genealogies crossed paths in those historical processes that brought the working class into the sphere of citizenship. In the practice of Western or, at the very least, European modernity, civil society - protected by first-generation rights typical of the Rechstaat - has provided the arena where the working class could voice its demands. Thanks to a series of long-lasting struggles for both recognition and redistribution, ${ }^{3}$ workers obtained not only political rights but also those third-generation rights - social rights - that permitted their full integration into the structures of liberal-democratic states. Indeed, one of the distinguishing features of democratic national-territorial states, especially in the European context, has been their capacity to function as mediators between labour and capital, by means of the redistribution mechanisms enacted by the welfare state. The 'social contract' thus produced lay at the heart of Western democratic polities, and represented a pivotal legitimising element.

Moreover, both models sketched above share one important feature: civil society is defined in a dialectic relationship with the state. Of course, such relationships may materialise through a very diverse morphology. If understood, in Hegel's wake, as the System der Bedürfnisse, civil society needed the state to act as a mediator and arbiter or, more specifically, as the source of those norms 
which would prevent its implosion under the pressure of conflicting interests. On the other hand, an important tradition within liberalism emphasises the need to draw a sharp dividing line between society and the state, minimising the latter's presence. Civil society, meant as the space both for not yet political social interaction and for economic activity, constantly needs to defend itself from the power of the state. Hence the importance of all those barriers - the so-called negative liberties - erected to protect society from the interference of political power. Tom Paine could be considered the forerunner of this trend; mutatis mutandis, opposition movements in the former Eastern bloc at the time of the great 1989 transformations often echoed this kind of anti-political language, and emphasised the distance between 'politics', seen to be heavily compromised with power, and an ideal of civil society as a space entirely immune from any temptation to exercise power and completely devoted to giving, "voice to the voiceless', in the words of Vaclav Havel, leader of the 1989 Velvet Revolution. An important contradiction within the liberal framework is evident here: civil society can be seen as the antagonist of the state but, at the same time, it has to become the source of its legitimacy.

This overview has been necessarily skeletal. Nonetheless, for our present analysis, it is important to recall one key aspect, as it, more than any other, faces major challenges in the present political and social circumstances. Civil society, considered both as 'market' and as 'public space', has been conceptualised mostly, if not exclusively, in relation to individual polities, traditionally defined by the borders of the national-territorial state.

\section{A post-national space in transition}

It is beyond the scope of this chapter to establish whether the present context can still be considered 'modern', or whether we are already living in a post-modern, hyper-modern or deutero-modern world. ${ }^{4}$ Undoubtedly, many distinguishing features of Western modernity have changed so profoundly as to justify the use of the category of 'second modernity'. This transformation may to a certain extent be summarised with reference to what has been defined as the paradigm shift from the 'vertical' framework of government towards a multi-tiered or multilevel model of governance. Obviously, the supposed crisis of national-territorial states is the main factor in such a transition. Nonetheless, the very expression 'crisis of the nation state' is in itself a matter for considerable debate, a debate that cannot be fully rehearsed in these pages. Globalisation does indeed impact on the traditional model of the state typical of Western modernity, but all the processes it entails cannot simply be deemed to cause a 'withering away' of the state. Their consequences are far richer in nuance and complexity, and it would be far too simple to describe the situation in terms of a straightforward 'decline' and loss of relevance of states. On the one hand, national-territorial states are indisputably experiencing growing difficulty in exercising effective control over their territory - a dynamic often described as a 'crisis' or even a 'loss of sovereignty'. On the other, states have to take up a new modus operandi, or, as in Sas- 
sen's words, have to participate in a new set of normative, territorial, economic and political 'assemblages', which may represent not solely an undermining but a transformation of their political agency. States are being 'denationalised' - or, with a different and perhaps more appropriate lexicon, 'deterritorialised' - and reconfigured in such a way as to become a major vessel for the fostering and shaping of processes taking place at the global level (Sassen 2006).

The role of civil society undergoes a dramatic transformation in the context of the post-national constellation. First of all, both models emphasise the protection of national-territorial state boundaries of national-territorial states. More significantly, civil society could be represented as the 'pulp' of individual states protected by the 'skin' or 'shell' of their territorially defined sovereignty. It is now evident that civil society is no longer a hortus conclusus, defended by the walls of individual polities, nor can its activity be conceived as being strictly limited to the 'domestic' sphere. Civil society organisations are actors in what used to be the space of international politics, a space that is now better represented by the image of a multi-level and multi-tiered Mobius knot of governance functions than by the traditional Westphalian vertical architecture. State and non-state actors interact at various levels of governance, and civil society organisations do not need to go through the filter of state institutions, but can exercise autonomously a protagonist role in many fields that used to be the exclusive province of states (Armstrong et al. 2004; chapters by Panighello, Godsäter and Söderbaum, and Borońska-Hryniewiecka in this volume).

Two main lines of reflection emerge from the matching of genealogical research and analysis of the present. Insofar as civil society is considered a source of democratic legitimacy, the challenge is how to rethink its role in the shaping of post-national public spaces that could still be defined as democratic. As far as the first line of reflection is concerned, a clear response is provided by those who, roughly speaking, recognise themselves within the ideal of 'cosmopolitan democracy'. This vision boasts a very noble genealogy, beginning with Kant, and is definitely worth careful debate and consideration. Within the broadly understood 'cosmopolitan' school many different views on the nature and role of territorially based polities coexist, from more to less radical. The broader consensus is that individual polities should gradually yield to supernational - and obviously democratic - political spaces. In spite of objections, cosmopolitan democracy has every right to respect and attention, as it grounds itself in the principle of 'all affected': in a globally interdependent world, territorial membership could hardly be considered a 'just' criterion for participating in decision making (Pogge 2002; Marchetti 2008). These theoretical and political perspectives basically identify the galaxy of transnational movements and NGOs as the embryo, or even better the avant-garde, of a vibrant post-national public sphere, capable of giving birth to genuine global public opinion, and thus to replicating on a post-national scale the process of the creation of public will, as described by theorists such as Habermas or Cohen and Arato.

Such a role is to take place in a context completely different from the development of modern democratic polities. At present it would be unrealistic to 
expect the development, on the super-national level, of permanent structures for the creation of a public will which could perfectly coincide with those typical of democratic representation organised within national-territorial states. On the other hand, there remains the problem of the quasi-absence of a politicalinstitutional framework at the super-national level (once again, with the remarkable exception of the EU, soon to be briefly discussed). This problem remains important, insofar as civil society is considered to be the result of acquisitive passions and of the interplay between economic and political actors. Within the context of a globalising world where the dividing line between political and economic power is becoming increasingly blurred, it would be too easy to simply discard this darker face of civil society. This model, if left unbridled, could very well result in a sort of Hobbesian bellum omnium contra omnes or, less dramatically, in a kind of invisible hand situation. Surely neo-liberal trust in the selfregulating power of society is not solid enough to shape a democratic post-national space (Keane 2003). The most sensitive and alert voices of the cosmopolitan school nonetheless recognise the need for a two-way exchange between global civil society organisations and new forms of global democratic institutions, and are aware of the danger represented by the most radical, or even 'populistic' approach to civil society (Fraser 2008).

The increasing role of global civil society has been debated not solely in the framework of normative philosophy. It has also been analysed in various disciplinary fields, from international relations to political science and sociology. Thus, global 'civil society', however defined, is already at work in a variety of contexts. However, descriptive analyses of the concrete functions of global civil society have often adopted a distinctly normative stance. Such is the case for those authors who regarded the weakening of state structures as opening up new spaces for political agency and, consequently, as holding the potential for a renewal of democracy (Albrow 1996; Beck 2005). In the extreme, the crisis of the traditional form of state would facilitate the emergence of a lively civil society on a post-national level, and this would translate into a more 'democratic', less authoritarian political space. From this perspective, civil society and its components have unprecedented potential. Authors such as Albrow, Rosenau and Beck, coming from different theoretical and disciplinary approaches, still share, although with different emphases, the conviction that the paradigm shift from government to governance may result in new opportunities for political agency and for the expression of social energies, as they are intrinsically inclined to work by consensus rather than coercion. The shift towards governance supposedly undermines vertical relationships and highlights 'horizontal' relationships, as civil society is often called to participate directly in the function of governance (Rosenau 2003).

Moreover, Rosenau holds that global governance relies on a set of tools that are different from those of traditional modern political actors. Rather than functioning along the vertical relationships typical of the modern state - largely resting on the threat of coercion - governance happens along the continuum compliance-defiance, less immediately relying on the capacity to exercise viol- 
ence. Rosenau also highlights the changing nature and utility of power, and the decreasing effectiveness of the traditional 'vertical' conception of power. For global governance to be effective, the most important resource is voluntary compliance rather than coercive capacity. Last but not least, Rosenau's theory rests on many important assumptions concerning a new capacity for political agency, since he points to the increasing 'skills' possessed by citizens of the contemporary world.

Ulrich Beck's work is especially relevant, as it places the issue of power at the very centre of his reflections. In short, Beck holds that civil society is the third actor, on an equal footing with political institutions and economic actors, in what he defines as the meta-power game of global governance (Beck 2005). In this complicated game of checks and balances, civil society may count on a specific set of tools. The first tool is moral authority: civil society organisations may expose to public contempt political institutions and major economic actors such as transnational corporations, thus eroding their consensus. Moreover, Beck also points to the power to manipulate consumption as a new possibility for nongovernmental organisations. The global market opens up new avenues for political participation, and the very act of buying becomes a crucial form of political action. In fact, Beck goes as far as to define global consumption as an initial form of global citizenship. It is almost superfluous to comment on how far, from this perspective, civil society has come from the Habermasian model. To a certain extent, it still provides the space where new political themes and issues are first brought to public attention. But it no longer focuses its action on becoming a breeding ground for government legitimacy. Rather, civil society is one actor among others in the 'metapower game', and, although moved by aims which may be different from those of all other actors, it still plays by the same rules and in the same style, resorting to media exposure, spectacular impact and a tough lobbying style.

In fact, these views - and in particular Beck's position - are grounded in a solid analysis of the actual morphology of global governance. This chapter does not deny the appropriateness of these diagnoses, nor does it claim to conduct sociological research into the emerging global civil society. Many excellent research projects are indeed mapping this galaxy - see the outstanding work of the Centre for the Study of Global Governance of the LSE (Anheier et al. 2002, $2003,2004,2005,2008$ ) - and what is left to do is rather to conduct a critical reflection on these sociological findings. Undoubtedly, the number of groups and networks active on public interest issues around the globe is still growing steadily after its explosion in the early 1990s. In addition, there is the presence of a number of actors that are atypical and hard to encase in a simple definition. Many questions still remain open, as pointed out in the Introduction to this present volume. First of all, civil society organisations do not always have crystalline accountability records, nor are they completely immune from the accusation of being centred in the 'first world', most notably in Europe, or of being somehow carriers of 'cultural normalisation' (Anheier et al. 2002, 2003, 2004, 2005, 2008; see chapters by Gilson and Godsäter and by Söderbaum in this 
volume). But the ambiguity of a post-national civil society is rooted at a much deeper level, that of the progressive loss of relevance of an autonomous role of 'politics'. In fact politics - political actors and, even more, political agency seems to be less and less capable of providing a meaningful perspective to collective actions, which are slowly but constantly sliding towards what used to be defined as 'social'.

Roles are shifting, and the real nature of 'civil society' in its post-national version is much more ambiguous and elusive than it may appear in all those definitions that identify it with the galaxy of the 'willing'. There is no justification for representing civil society as a space immune from the exercise of power. Public, domestic and post-national spaces all see a profound transformation in the number and nature of their actors, as well as in the nature and formulation of the issues that are considered to be worthy of public discussion. It is clear that those specifically political subjects whose role was to channel and transform into proper political issues the claims surfacing in civil society are experiencing a deep crisis. Public spaces are being increasingly colonised by issues that a few decades ago would hardly have qualified as political - such as themes concerning ethics, lifestyles, and ultimate values. Symmetrically, public spaces are becoming increasingly populated by actors who cannot be defined as specifically political, but who are, in fact, typically social. Many so-called third-sector organisations are transforming themselves into institutional actors - or into good, sound businesses while big enterprises and companies often take up campaigns for justice and human rights, replacing to a large extent the space of action that used to belong to national-territorial states (see chapter below by Itçaina). In many cases, both third-sector organisations and economic actors find themselves cooperating to fill the vacuum left by states, which find it increasingly hard to intervene in issues of redistribution and social inequality, and to reinforce that specific 'social contract' between capital and work that was at the very root of liberal democracies. The dominant modus operandi seems to be oriented more towards bargaining and exercising pressure on the already existing power structures rather than on opening spaces of public debate conducive to the shaping of a real 'public will'.

The changing role of civil society in the post-national world cannot be separated from the transformation of politics, of its actors and modes of action. This chapter does not intend to launch into an in-depth analysis of 'what is politics?' Of course it is imperative to clarify what is meant by the opposition between the social and political - this question is of such magnitude as to require much more space and time, not to mention theoretical strength, than can be offered here. More modestly, it limits itself to recalling basic references, focusing on the specific question of political power. Civil society in modernity emerged and grew in a dialectic relationship with political power, in most cases concentrated within the specific locus of the 'state'. This dialectic can be read according to the Foucauldian model - civil society as an instrument of domination - but it can also be conceived as highlighting the role of civil society in the creation of democratic legitimacy. Even in this second model, however, the problem of power cannot be avoided and must be confronted. The mechanism of democratic 
representation, structures of accountability and, more than anything else, the possibility of public debates conducive to the formation of a public will, made it possible for political institutions to become something more than mere instruments of domination, even though they maintained their capacity for coercion. The political and constitutional structures that have historically been the product of the national-territorial (modern) model of state have made it possible for individuals to think of themselves as actors capable of autonomy, thus discovering an answer to the compelling dilemma of finding a legitimising narrative to justify the very existence of political power. In all the genealogy that sees it as the point of origin of legitimacy, civil society is essentially connected to the legal-rational determination of political power and, more specifically, to popular consensus as a source of legitimacy - and therefore, ultimately, as a source of personal moral and political autonomy. Seen from another point of view, civil society, by the very fact of constituting the tribunal of public reason, and consequently the foundation of legitimate power, necessarily aims to transform itself into that same institutional structure it used to oppose - the normative power of the state.

The conquest of the state was the focus of modern political agency, as it was typically affirmed in Politik als Beruf (Weber in Owen and Strong 2004). According to Weber, an action may be defined as political if it aims to conquer the state, because the state is the one body that has the monopoly on the legitimate use of force. This reference helps to throw light on one of the main lines of transformation from the first to the second modernity. It is almost redundant to stress how hard or, rather, impossible the contemporary context would make it to apply this same mechanism to post-national civil society. It is evident that the conquest of the state is far, very far, from being the essential goal of political struggle. If the state is no longer the political actor par excellence, it is not surprising that the control of the specific loci of political power is no longer the supreme aim of social struggles: the goal is to influence, rather than control, specific political institutions. In other words, what is at stake is the possibility of influencing the bodies that hold the keys of power, rather than conquering them and replacing the original occupants. As Manuel Castells (1998: 352) said once, there is no Winter Palace to seize. In a situation where the state is no longer the central actor, but one actor among many, the goal of the struggle is to influence those in power. With Bauman (1999), one could say that politics in the age of globalisation can be represented as an airplane with an empty cockpit - empty because no one is really interested in holding the control column. Hence, the growing relevance of those resources which are typical of civil society, such as knowledge, or moral authority, or that particular kind of power that Beck defines as the power of shame, for exercising skilfully targeted 'blackmail'.

The often invoked crisis of the state, as has been observed above, is not the only possible key to understanding these transformations. Globalisation processes - or, to use less popular vocabulary, new forms of post-industrial capitalism - make it easier for civil society to organise and exercise agency on a super-national level, but this process does not automatically lead to a postnational democracy. Rather, the changing role of civil society in a post-national 
space has to be read as part of the overall fresco of the transformation of democratic polities into some sort of a post-democracy; namely, a situation where civil society groups mobilise in a variety of ways, participate in governance functions and compete for influence, but where the decision-making power is to a large extent immune from popular control and accountability. ${ }^{5}$

\section{The European case}

No reflection on civil society could be considered complete without a reference to the European context. Notwithstanding all its evident shortcomings, the European Union is, at the present moment, the most developed post-national polity (some would even call it post-sovereign and post-modern), as well as a particularly sophisticated example of multi-level governance. In EU governance the role of civil society is nothing short of pivotal. However, the dominant understanding does not focus on its nature as the breeding ground of public opinion or as a source of legitimacy. On the contrary, civil society is conceived primarily as the whole of organised interests. EU official language, therefore, presents a vision closer to the Hegelian than to the Habermasian model, as is quite clearly visible in the White Paper on European Governance by the Prodi Commission (European Commission 2001). Actors from the world of economics, such as corporations, industries and trade unions, have a long-standing tradition of powerful lobbying in Brussels. Organised interests cooperate in EU policy making through formal channels (such as the Social and Economic Committee) and also through very effective informal channels - channels that have been made even more effective by the trend towards 'open' methods of coordination in governance (see chapters by Bello and Ruzza in this volume). In recent years, traditional lobbyists representing corporate interests have been joined by the so-called PIGs (public interest groups) - NGOs with agendas ranging from racism, to the environment, to consumers' rights, which have flocked to Brussels in growing numbers. More and more PIGs and NGOs have found ways to influence EU policy making, breaking the monopoly of the great financial lobbies, and learning their enemies' skills and techniques for influencing EU legislation in matters of public concern, such as racial equality, the preservation of the environment, gender rights, and justice (Ruzza 2006; Greenwood 2007).

These transformations mirror the internal evolution of the EU and its quest for legitimacy that is not exclusively based on output. Insofar as it needed to reassess its nature as a fully fledged polity, the official bodies of the EU have reaffirmed the role of civil society, especially as a remedy for the much-lamented democratic deficit. However, the effective impact of civil society organisations on EU legitimacy can be felt predominantly in terms of performance-based, expost legitimacy, rather than in terms of procedure-based, input legitimacy (Scharpf 1999; Cerutti 2008). ${ }^{6}$ In other words, civil society, meant as both PIGs and interest groups, strengthens performance-based 'output' legitimacy, as it contributes to the good governance of the European Union. Both lobbies and PIGs in fact play a crucial role, providing policy makers with information and 
feedback. Moreover, civil society organisations and NGOs in general exercise an increasingly essential role in the specifically European approach to security, as is evident in the European Neighbourhood Policy (Panighello in this volume). This continuous exchange reinforces ex-post legitimacy, as it ensures better governance and lessens the possibility of social conflict arising within specific policies: the question remains as to whether it opens up more space for democratic participation. Civil society does not - or not yet - contribute to input-based legitimacy, as it is still far from being the breeding ground for a European public opinion capable of converting itself into a fully fledged political actor. And it could hardly be otherwise, as the very structure of the European Union does not encourage the birth of actors characterised by a broad and specifically political agenda. On the contrary, it facilitates the presence of very specialised and issueoriented organisations. At the present moment, it looks as though the relationship between the EU and PIGs is being shaped in the same way as the relationship between the EU and private interest lobbies. Civil society organisations therefore exercise their specific form of power - naming and shaming and trade their specific resources, such as moral authority, expertise, and field knowledge. Not only is this model of governance far removed from any deliberative model, as it has often been lamented, it is still very far removed from some of the elements that were considered essential for a genuine democratic life, characterised by the establishment of public fora of discussion and supported by open and public structures of accountability. The absence of institutional structures that may claim to be representative of a real European public encourages a governance 'European style', which tends to minimise conflicts and to privilege bargaining, consultations, and negotiations. Political institutions and actors are either irrelevant or beyond reach, and therefore do not represent an appetising prey. Therefore, the European Union remains governance for the people - such is the essence of its output legitimacy - and to an ever-growing extent with the people, as is demonstrated by the many instances where civil society organisations, lobbies, and public interest groups cooperate in the function of European governance. Nonetheless, the EU still cannot be defined as governance by the people (I am borrowing 'for, with and by' from Schmidt 2006) or as a technocracie ouverte, to use the very perceptive definition by Paul Magnette (2003). Whatever the definition, the participation of civil society in European governance confirms, or even emphasises, a trend that could be defined as postdemocratic. The EU can therefore be considered a workshop where the dynamic focus remains on individual polities, rather than on influencing the emerging global public space.

\section{Concluding remarks}

The brief references made above to Foucault may now come in handy. Of course they are not meant to herald a mechanical neo-Marxist analysis or a Foucauldian orthodoxy, and even less should they result in undermining all the effective liberating and empowering potential shown by civil society organisation in our 
contemporary world. Nonetheless, they both point to two important lines of analysis. On the one hand, the Lectures au Collège de France may help us to grasp some of the most elusive features of the relationship between civil society and power, in all its different forms: political, economic, social. Commenting on a quote by Ferguson, Foucault reminds us that power comes into being simultaneously with the establishment of social bonds (Foucault 2008: 291). This lesson should not be forgotten when analysing all the ambiguities and contradictions marking our contemporary context.

This does not mean, of course, that only territorial states carry political autonomy. It means that unpleasant questions deserve to be considered most seriously. The challenge is to understand whether the expansion of an increasingly unpolitical politics is truly and exclusively good news for the future of democracy, and if the presence of a strong and vital civil society per se is sufficient to ensure the democratisation of the post-national public space. Attempting to apply the theoretical and historical models of the first modernity to a context that is so profoundly changed is evidently pointless; on the other hand, it is also important to keep a critical eye on the transformations. Civil society is not only the voice of the voiceless - it is a form of public space where power cannot be ignored or exorcised. If power is not channelled into post-national political and constitutional forms, civil society risks becoming the breeding ground for postdemocratic public spaces rather than for post-national democracies.

\section{Notes}

1 The use of the term 'men' is intentional. In fact, in mainstream Political Theory only men can participate in the establishment of the political covenant, while in Hegel's political theory women remain confined in the private sphere of the oikos.

2 The gender dimension in the birth of bourgeois civil society deserves a separate, indepth analysis. Suffice it to say, for this chapter, that the bourgeois public sphere at its inception somehow tolerated the presence of women insofar as it developed in a sort of 'grey area' between an exquisitely 'public' space and a 'private' one. The French Revolution then pushed women back into a dimension of privacy by reinforcing the dividing line between public and private (see Landes 1988; Benhabib 1993; Fraser 1993).

3 The reference is obviously to the dialogue in Fraser and Honneth (2003).

4 On this debate, see at least Albrow (1996), Beck (1998), and Giddens (1990).

5 It is well known that this term has been brought to the wide attention of the public by Colin Crouch (2004). In my analysis I use this term in a slightly different sense.

6 I have also discussed this point in Spini (2008).

\section{References}

Albrow, M. (1996) The Global Age: State and Society Beyond Modernity, Stanford: Stanford University Press.

Arendt, H. (1973) On Revolution, Harmondsworth: Penguin Books.

Armstrong, D., Lloyd, L., and Redmond, J. (2004) International Organisation in World Politics. The Making of the Twentieth Century, 3rd edn, Basingstoke: Palgrave Macmillan. 
Anheier, H., Glasius, M., and Kaldor, M. (eds) (2002) Global Civil Society 2002, Oxford: Oxford University Press.

- (eds) (2003) Global Civil Society 2003, Oxford: Oxford University Press.

(eds) (2004) Global Civil Society 2004-5, London: Sage Publications.

(eds) (2005) Global Civil Society 2005-6, London: Sage Publications.

(eds) (2008) Global Civil Society 2007-8, London: Sage Publications.

Baker, G. and Chandler, D. (eds) (2005) Global civil society. Contested futures, New York: Routledge.

Bauman, Z. (2004) In Search of Politics, Cambridge: Polity Press.

Beck, U. (1998) World Risk Society, Cambridge: Polity Press.

- (2005) Power in the Global Age. A New Political Economy, Cambridge: Polity Press.

Benhabib, S. (1993) 'Models of Public Space: Hannah Arendt, the Liberal Tradition, and Jurgen Habermas', in Calhoun, C. (ed.) Habermas and the Public Sphere, Cambridge, Mass.: The MIT Press.

Castells, M. (1998) End of Millennium, Malden, Mass.: Blackwell.

Cerutti, F. (2008) 'Why Political Identity and Legitimacy Matter in the European Union', in Cerutti, F. and Lucarelli, S. (eds) The Search for a European Identity. Values, Policies and Legitimacy of the European Union, London and New York: Routledge.

Cohen, J. and Arato, A. (1992) Civil Society and Political Theory, Cambridge, Mass.: The MIT Press.

Cox, R. W. (2002) The Political Economy of a Plural World: Globalization and Civilization, New York: Routledge.

Crouch, C. (2004) Post-democracy, Cambridge: Polity Press.

European Commission (2001) A White Paper on European Governance, COM (2001) 428 final, Brussels, 25 July 2001. Online. Available http://eur-lex.europa.eu/LexUriServ/site/en/com/2001/com2001_0428en01.pdf (accessed 9 March 2010).

- (2002) Communication: Towards a Reinforced Culture of Consultation and Dialogue - General Principles and Minimum Standards for Consultation of Interested Parties by the Commission, COM (2002) 704 final, Brussels, 11 December 2002.

- (2005) The Commission's Contribution to the Period of Reflection and Beyond: Plan D for Democracy, Dialogue and Debate, COM (2005) 494 final, Brussels, 13 October 2005. Online. Available http://ec.europa.eu/commission_barroso/wallstrom/ pdf/communication_planD_en.pdf (accessed 9 March 2010).

- (2006) Green Paper on European Transparency Initiative, COM (2006) 194 final, Brussels, 3 May 2006. Online. Available http://ec.europa.eu/transparency/eti/docs/gp_ en.pdf (accessed 20 June 2007).

Falk, R. A. (1995) On Humane Governance: Toward a New Global Politics, Cambridge: Polity Press. (1999) Predatory Globalization: A Critique, Cambridge: Polity Press.

Foucault, M. (2008) The Birth of Biopolitics: Lectures at the Collège de France, 1978-1979, Basingstoke and New York: Palgrave Macmillan.

Fraser, N. (1993) 'Rethinking the Public Sphere: A Contribution to Critique of Actually Existing Democracy', in Calhoun, C. (ed.) Habermas and the Public Sphere, Cambridge, Mass.: The MIT Press.

— (2008) Scales of Justice: Reimagining Political Space in a Globalizing World, New York: Columbia University Press.

Fraser, N. and Honneth, A. (2003) Redistribution or Recognition? A Political-Philosophical Exchange, London: Verso. 
Giddens, A. (1990) The Consequences of Modernity, Cambridge: Polity Press.

Greenwood, J. (2007) Interest Representation in the European Union, 2nd edn, Houndmills and New York: Palgrave Macmillan.

Habermas, J. (1991) The Structural Transformations of the Public Sphere: An Inquiry into a Category of Bourgeois Society, Cambridge, Mass.: The MIT Press.

— (1996) Between Facts and Norms, Contributions to a Discourse Theory of Law and Democracy, Cambridge, Mass.: The MIT Press.

Keane, J. (2003) Global Civil Society?, Cambridge: Cambridge University Press.

Landes, J. B. (1988) Women and the Public Sphere in the Age of the French Revolution, Ithaca, NY, and London: London University Press.

Magnette, P. (2003) Contrôler l'Europe: Pouvoir et responsabilités dans l'Union européene, Brussels: University of Brussels.

Marchetti, R. (2008) Global Democracy: For and Against Ethical Theory, Institutional Design and Social Struggles, New York: Routledge.

Owen, T. and Strong, T. (eds) (2004) Weber. The Vocation Lectures, Indianapolis, Ind.: Hackett Press.

Pogge, T. (2002) World Poverty and Human Rights: Cosmopolitan Responsibilities and Reforms, Cambridge: Polity Press.

Rosenau, J. (2003) Distant Proximities: Dynamics beyond Globalization, Princeton, NJ: Princeton University Press.

Ruzza, C. (2004) Europe and Civil Society. Movement Coalitions and European Governance, Manchester: Manchester University Press.

— (2005) 'EU Public Policies and the Participation of Organized Civil Society', Working Papers of the Department of Social and Political Studies, University of Milan. Online. Available www.sociol.unimi.it/papers/2005-11-23_Carlo\%20Ruzza.pdf (accessed 20 June 2007).

- (2006) 'European Institutions and the Policy Discourse of Organised Civil Society', in Smismans, S. (ed.) Civil Society and Legitimate European Governance, Cheltenham: Edward Elgar.

Sassen, S. (2006) Territory-Authority-Rights. From Medieval to Global Assemblages, Princeton, NJ: Princeton University Press.

Scharpf, F. (1999) Governing in Europe: Effective and Democratic?, Oxford: Oxford University Press.

Schmidt, V. (2006) Democracy in Europe: The EU and National Polities, Oxford: Oxford University Press.

Spini, D. (2008) 'The Double Face of Civil Society', in Cerutti, F. and Lucarelli, S. (eds) The Search for a European Identity, London and New York: Routledge. 


\title{
2 Collective and social identity \\ A theoretical analysis of the role of civil society in the construction of supra-national societies ${ }^{1}$
}

\author{
Valeria Bello
}

\section{Introduction}

In the last century after the end of the bipolar system, the international arena witnessed important advances in regional integration projects. As Farrell's book shows, regionalism is a response to globalization 'as both a defensive and as an offensive strategy' (Farrell et al. 2005: 2). Members of regional integration processes try to sort out common problems and to strengthen their role in the world through collaborative action. In addition, while from the middle of the twentieth century until the end of the Cold War the development of international institutions was only a state affair, nowadays all events in the international arena are also a society affair. This is due to several factors, including an increasing commitment to civil society at the global level and greater citizen awareness of their role in public life, and their consequent involvement in politics. However, even though citizen participation in the EU governance system has no parallel in other similar regional integration processes, and is indirectly guaranteed through the European Parliament and an institutional commitment to consultation with civil society, a large proportion of Europe's citizens are not interested in having a voice in the EU's political system. This is clear from the low participation of voters in the 2009 European Parliament elections. Consultation with civil society was intended to improve linkages between the EU and its citizens (EU Commission 2001), after the European Commission acknowledged that citizens' sense of belonging to the EU was weak, mainly because the EU was considered to exist at a distant institutional level.

The interesting point is that, even at the national level, states often encounter problems due to the fact that some of the citizens living in territories that are part of the country do not identify with the central state. In fact, some European states are currently witnessing protests and requests for independence by separatist movements. People's discontent due to economic or social problems can be easily channelled - sometimes by exploiting populist feelings - into complaints about the very fact of being included in a state which they do not identify with because they cannot see any commonalities with the other members of the state. Such populist appeals reveal a lack of solidarity between different districts of a country, which can consequently create fractures at a national level. Examples of 
these protests are in Northern Italy, the Basque Country in Spain, and formerly in the Czech Republic, which in consequence succeeded in separating from Slovakia on 1 January 1993. Therefore it should be clear that the lack - or even the loss - of a 'commonness' is something that, if exploited by separatist movements, could threaten not only the legitimacy of a democratic system (as asserted by important scholars, notably Scharpf 1999) but the very existence of a country or other territorial form of government, including regional integration processes. That is why, during the conquest of a territory, a new power tries to construct a new collective identity in addition to new governmental structures (Anderson 1983) and, more generally, dominant groups always struggle to achieve a 'cultural compromise' which will then be imposed on the territory through social 'closure' towards others (Wimmer 2002).

The two most classic perspectives on the formation of states locate it in ethnos (Smith 1986) or in demos (Gellner 1983; Deutsch 1954). At the European level, the debate can be summarized by the two well-known positions taken by Dieter Grimm and Jürgen Habermas when discussing the existence (or 'the possibility of a formation') or absence of a European demos (Grimm 1995; Habermas 1995). Habermas raised the idea of constitutional patriotism, which we can now consider the theoretical starting point of the EU constitutionalization process (Habermas 1995, 1998). It is no surprise then that the failure of the European Constitution has been considered as initiating a period of crisis for the EU. Indeed, as the regional integration project is currently 'in process' (under construction), scholars have the opportunity to witness its development and examine for themselves the possible paths this process might take, while giving shape to its constituency.

Then, identity issues can also strongly impact on regional integration. This is not a new idea, if we consider that some of the oldest and most famous integration theorists, despite their differences, all considered common norms, common interests and common values essential for the further advancement of regional integration processes (Scartezzini 2004). Such theories included Amitai Etzioni's political unification (1965); Ernst Haas's neofunctionalist theory (1958, 1960, 1964); and Karl Deutsch's 'security community' (1954, 1957). Now this chapter intends to highlight that, particularly at the regional ('supra-national') level, other forms of solidarity and the construction of 'group sense' are possible, rather than what Wimmer (2002) identified as 'the cultural compromise' at national level.

Among members of an international community, such as the EU and other regional institutional actors, a common identity cannot be represented by strict cultural or ethnic criteria. The formation of ethnic and cultural identities - even if, of course, constructed and imagined (Anderson 1983) - can occur in small communities and are still possible in a national context. It can be encouraged through the construction of myths, collective memories, rituals and behaviour. However, most of the literature suggests that this is unlikely to happen at a macro-regional level, because of the diversity of interests, cultures, histories, and not least because of the lack of a common language (Grimm 1995; Miller 
1995). Some authors consider it possible to build a regional identity with the help of the same mechanisms of identity construction as are used in the process of nation-building, such as common educational programmes, common themes and myths, or the common construction of news and demands (Castells 2002; Eder and Spohn 2005). And this is indeed what the EU intended to do with the construction of symbols (the flag, the euro, the European anthem), the use of the European classical myth (the rape of Europa by Zeus in the form of a white bull), or through education and mobility programmes (such as the Erasmus Mobility Programme or the Jean Monnet Action and, in general, all those actions that the EU implements in order to diffuse knowledge and information about the EU itself). In sum, while the possibility of a common identity at regional level is denied on the one hand because a 'shared past' is missing, on the other hand it is affirmed on the basis of 'sharing a future'. In any case, the evidence of 'cultural' commonalities (already existing or to be constructed) is considered necessary.

But is that really true? Is it true that too many interests, too many histories, and different languages are elements that impede the forging of a common identity? And were these elements to exist, should we consequently think that a regional identity could develop? In Latin America, even though states share a language, a religion, a history and interests, there is no regional identity, while in Africa, divided into thousands of fratrie, ${ }^{2}$ groups, communities - even in war in some cases - with plenty of languages and several religions, a certain regional identity has formed and regional integration processes have made giant steps in recent years. How is it possible to explain these facts? The first question this chapter aims to explain pertains to the mechanisms for identity construction. The second question concerns why it is possible to construct a regional identity and examines the kinds of identity that can be found at regional level.

One of the best works on collective identity and the sense of belonging, Imagined Communities (Anderson 1983), outlined the role of institutions in the construction of collective memories, myths and other elements which were used in the last century to construct national communities. Therefore these mechanisms form collective identities through vertical (top-down) dynamics, from the state and its institutions to the people. However, as illustrated by important scholars (Blumer 1963, 1969; Berger and Luckmann 1966; Castells 1997; Giddens 1991; Simmel 1890; Tajfel and Turner 1986; Turner 1982), there are also other mechanisms of identity construction, which operate through horizontal dynamics. They take place through the action of individuals and groups of citizens who interact and shape what is known by sociologists as social identity. ${ }^{3}$ Currently, at the regional level, individuals and citizens' groups have acted together in the formation of civil society, thus contributing to the construction of a regional identity through horizontal dynamics. This chapter intends to introduce into the debate on macro-regional identity a concept that has hitherto been neglected by both international relations (IR) scholars and political scientists, and to examine the role that civil society plays in this particular process of identity construction. 


\section{Collective identity vs social identity}

\section{A definition of identity}

The Introduction has already answered the question of why IR scholars should be interested in identity, and a plentiful literature about its importance can also be found within constructivism. The latter differs from other IR approaches because of the role it gives to identities and values (Checkel 1998, 2007; Katzenstein 1996; Wendt 1999). But what is identity? Different disciplines use the term in different ways and the concept brings with it different meanings. As a result, it also sometimes implies certain ambiguities, as argued by Brubaker and Cooper (2000), who suggest the need to avoid the term and to use other less ambiguous concepts. As the aims of this chapter are already broad, I refer to Jenkins (2008) for a reply to this argument made by the two authors, and in particular I agree that:

What's more, even when we stop talking about 'identity', we would still need a way of talking about the fundamental human process that I have been discussing in this chapter. We would still require abstract, shorthand terms that allow us to think about 'knowing who's who' and the fact that people are, in their own eyes and in the eyes of others, identified as this, that or the other.

(Jenkins 2008: 14)

Identity explains who's who and this explanation can be achieved by investigating in different directions. It is possible to research identification, attitudes and the sense of belonging. Part of the literature concerning the EU actually discusses these issues (Diez Medrano 2003; Eder and Spohn 2005; Ruiz Jimenez et al. 2004). However, when referring to a collective actor such as a regional integration process like the EU, we might also refer to political identity (or better to self-representation); that is to say norms, principles, beliefs, values and ideas that, in the eyes of this actor, represent what he is and what he consequently intends to apply politically through his actions (Haller 2000; Olsen 2007; Sedelmeier 2003; Cerutti and Lucarelli 2008). Other scholars have published works on the external image that a political system or regional integration process can have, thus talking of international identity (Bello 2010; Davidshofer 2005; Lucarelli 2007; Manners and Whitman 2003; Smith 2008; Whitman 1997).

In Luhmann's theory, identity is considered as what allows the system to control its own operations through those actions which the different environments composing the system itself have in common - the system's identity (Luhmann and De Giorgi 1991). Following this reasoning, it is possible to apply this definition to any type of identity: personal identity, ${ }^{4}$ role identity, group identity. Considering collective actors as regional integration projects, this chapter focuses on how it is possible to construct a common identity, at regional level, through the formation of common interests and common attitudes, rather 
than on the basis of common cultural elements. In other words, this chapter analyses whether there is a different way to keep together the different parts of a political system, for example in a regional integration, without appealing to common 'cultural' aspects. Is it still possible to do it in a 'societal' manner, to recall a Weberian concept (Weber 1922)?

As argued in my previous work (Bello 2010), identity can be considered a system of reference for action and of meaning for communication to explain who's who. This is a general definition of identity which focuses on the function rather than on the contents of identity. Thus, it can also be used, like Luhmann's definition, as an analytical tool to refer to whatever type of identity (personal, role, collective and social). It can explain to those members who share it the socially meaningful borders of their actions and how they can express these visà-vis others. This is simply a different way of explaining who's who. Taking into account a different definition of identity, such as that of Wenger (1999), it is clear that the essential function is still the same, even if not emphasized by the author. Wenger in fact argues:

Engagement in practice gives us certain experiences of participation, and what our communities pay attention to reifies us as participants.... As an identity, this translates into a perspective. It does not mean that all members of a community look at the world in the same way. Nonetheless, an identity in this sense manifests as a tendency to come up with certain interpretations, to engage in certain actions, to make certain choices, to value certain experiences - all by virtue of participating in certain enterprises.

(Wenger 1999: 150-153)

I share this perspective. Even if Wenger focuses on practice while this chapter focuses on interaction, and thus the processes of identity construction considered are different, the function played by identity is the same in both definitions. Identity serves to guide (or indicate borders for) action and, it is worth adding, to make communication intelligible. It serves to guide action, because when a person is in a particular and known context, he/she distinguishes how to make others understand who he/she is through his/her own actions, by sharing the behavioural code of that context. Similarly, others can recognize the rules of that context, its norms; and can predict reactions to actions because the accepted behavioural code within that context is known and shared. The forming and sharing of this information are the processes of identity construction and selfunderstanding respectively.

Identity also makes communication intelligible - so people can communicate with each other - because they know the meanings given to things in their context. This can depend on the existence of a common language or on the presence of a vehicular language - as in the African continent where classical Arabic and French make communication possible between people who speak different mother tongues. The important fact here is that people who share an identity know what is meant by any given sentence. It is of course clear that the better a 
language is understood, the easier communication becomes. However, without a shared identity, a common language alone does not imply the sharing of meanings. When a person does not know a context and its identity, he/she cannot interact in a meaningful way with its members.

\section{Vertical and horizontal dynamics of identity construction}

This chapter focuses on the different ways of constructing these shared meanings and information at group level. I have called identity the system which allows meanings and 'information on norms and values' (the behavioural code) to be shared. All the groups have this system. This is true for collective actors, such as parties, associations, NGOs or, at a wider level, a regional actor such as the EU. ${ }^{5}$ Indeed, these all have collective self-understandings, which can be considered as the frame of their actions. But what are the actual mechanisms that allow the construction of an identity? In other words, how does the process of identity construction work? Until now, scholars of the constructivist approach have analysed this issue by considering vertical - hierarchical - dynamics (the role of dominant groups, institutions and so on) particularly at national level (Calhoun 1997; Anderson 1983; Wimmer 2002). Horizontal dynamics (the role of individuals' and groups' interactions) have been taken into account by some interesting works mainly at regional level (Checkel 2007; Garcia Faroldi 2008). I thus consider it to be worth distinguishing two different types of identity formation, by theoretically separating the hierarchical from the horizontal dynamics.

Therefore, when a collective actor emphasizes the vertical (top-down) dynamics of identity construction, I use the concept of collective identity. However, horizontal processes of identity construction also exist, and in this case the social identity concept will be used to refer to the results of individual actions in the framing of possible socially meaningful borders for action (Jenkins 2008; among the classics see Blumer 1963, 1969; Berger and Luckmann 1966; Simmel 1890; Tajfel and Turner 1986; Turner 1982). Through social interaction people learn the rules, meanings and values of a group and may then contribute to changing them. Thus, this process shapes a form of social identity that individuals assume and contribute to daily through contacts and interaction. In this way, the horizontal dynamics of identity construction takes place through the creation and diffusion of attitudes, norms, values and meanings. In contrast, collective identity is a term which suggests vertical, top-down processes of identity construction set up by a collective actor or dominant groups, which people can then choose to identify with.

\section{Consciousness vs rationality: a useful distinction}

Social identity, being constructed horizontally by individuals or groups through interaction, is not the result of given representations of commonality, but it is the result of a spontaneous ${ }^{6}$ process that is part of daily contacts and interaction. Therefore, it is an open and inclusive process that adapts to changes. Collective 
identity is formed by a fixed image, which has precise borders and defines itself by confronting what is outside. This is an exclusive and ascribed process of identity construction. The resulting form of identity implies the development of a sense of belonging (a consciousness) because one feels a member of a given community. And that is in fact the final aim of the collective actor that has created that identity. An example is the collective identity of a political party: if a person is left-wing, he/she is known to be a left-wing-oriented voter; he/she will adopt specific behavioural norms, or even a particular idiom. This is the result of a process of identity construction directed from the top. Instead, social identity, derived by interaction, depends on long-term daily interaction in a context and does not issue from a joint desire to share a collective identity. A very clear example is the case of migrants: an African person who lives in Naples will speak Italian with a different accent from his/her countrymen living in Milan. However, this is something which is not the result of a conscious will aimed at constructing an image of a particular identity; it is just the consequence of social interaction in a context where a person hears a particular accent daily.

Nowadays, this social interaction happens in a context that is also influenced by the regional and the global level and not only by the national one. For example, 'globalized' people, even if living in different parts of the world, give the same importance and social meanings to the same objects, such as the iPhone, and Facebook. However, they usually do not know that this is the result of their daily interaction in a global context, but would be likely to consider those objects as symbols of social status. They do not have a sense of belonging to a global identity, while they will certainly say 'I am Italian', 'I am French' or 'I am English'. However, this daily interaction in a 'global' context will influence their life and actions in the same way that their national 'social location' does. The straightforward distinction between social and collective identities given above maintains that the second is constructed from the top. Institutionally, politically or even culturally, this depends on the means and contents used by those who construct it. Moreover, individuals feel, know and sometimes decide that they belong to a group (a political party, national or subnational community, and so on). Therefore, collective identity always entails a sense of belonging, because it is recognized (through a process which develops consciousness) as an element of distinction towards 'others' and of identification with people belonging to the same community. While social identity does not create feelings of belonging, it can imply some form of membership. In any case, it is always constructed through social interaction and horizontal dynamics, and it does not depend on 'ethnicity'.

It is worth emphasizing that consciousness, used until now to understand differences between social and collective forms of identity, is something completely different from the rationality existing (or not) behind the identification with a group. Rationality is an element that first Weber and then many others used to distinguish between communitarian socialization and societal socialization (Weber 1922; see also Delanty and Rumford 2005; Dubar 1998). Indeed, consciousness of a collective identity depends on a sense of belonging: on the 
fact that a person knows perfectly what he is expected to be by the group he feels he belongs to - a left-wing party member, or a Nazi group member, or part of the Italian nation. This consciousness is different from the rationality or lack of it of an identity-building process. It can also be irrational. Let us take the example of the Nazi identity shared by soldiers of the German army during the Second World War: it was a collective form of identity with a very strong sense of belonging; conformity to the rules was absolutely 'conscious'. However, it was not built on rational interests, but on elements that appealed to emotions and other irrational feelings (xenophobia, racism, sense of primacy).

Therefore, this chapter focuses on consciousness as 'other' compared to the emotional or rational contents of identities. Here consciousness represents a way of distinguishing between vertical dynamics of identity construction, which are downwardly constructed by a collective actor (for instance the state and its institutions) or by dominant groups, and horizontal dynamics of identity construction, which take place through interaction and contacts and which create a so-called social identity.

Examples of social identity are difficult to recall, as they do not involve feelings of belonging. However, it is possible to consider the outcomes of social identity in broad areas such as civilizations. In fact, no collective actor constructs civilizations, but they are the result of long-run processes derived from philosophical thought, literature and history. They are open processes, which adapt to changes and thus have shifting borders. They do not always entail strong feelings of belonging, but can create forms of membership. Another example of social identity is cosmopolitan identity, which is open, inclusive and not vertically constructed. However, as will be mentioned below, social and collective identities are ideal types constructed to help analysis; the reality is far more complex as both processes are involved, to a different extent, in the construction of any one identity.

It is worth distinguishing between these concepts for two main reasons. First, it will help to highlight that ethnic identities are not a form of social identity. In fact, they always entail a sense of belonging (and not membership); so they are not social, spontaneous identities created by interaction among individuals, but are supposed to have natural origins. 'Ethnic' identities are fixed images of a group, stable in time and with hard borders, so they are mainly forms of collective identity. ${ }^{7}$ Second, and theoretically more important, social identity, being formed by a spontaneous and inclusive process of identity construction, is more likely to shape rational types of identity, such as those described by Weber through societal socialization.

\section{Communitarian and societal socializations: ideal types of identity construction}

Weber's distinction between communitarian and societal socialization is based on the existence (or lack of it) of rationality in the process of identity construction. He illustrates that the first (the communitarian) is based on expectations resulting 
from customs and shared values; it implies a community of belonging (Verband) and a common language; it is an emotional rather than a rational process. In contrast, societal socialization is the expression of different interests, based on rules established through rational scope-oriented behaviour (Zweckrationalität). Therefore, the voluntary conformity of individuals to these rules is based on a rational agreement on common but limited interests (Weber 1922). In the EU we could refer, for example, to the concept of civilian power, to the culture of individual freedoms and to the European Social Model (see Bello 2008, 2010). This is also what Delanty referred to as societal identity (see Delanty and Rumford 2005). It is constituted by those elements derived from the arts, philosophy, literature and historical events, which formed a European culture in a broad sense, intended as a form of 'civilization' (in Huntington's terms, 1996). Societal identity is therefore the result of interaction on the continental territory considered from a historical viewpoint. Therefore, a civilization can be considered a consequence of long-run social interaction and the outcome of social identity. This argument is made clearer if we consider it through a systemic approach: the interaction of individuals contributes to the formation of social identities; these create - in the long run and at the widest level reached by the system - common elements of a civilization. In turn, the latter, once formed, influence individual and social identity. In other words, we have a circular process, made of upward and downward dynamics of identity construction processes (see Figure 2.1).

Societal socialization does not represent a passive conditioning designed to make individuals belong to a certain grouping, entry to which is established by sharing a past, a language, blood and other 'natural' linkages, as happens in communitarian socialization. Rather, societal socialization is rational and entrance to the society is open; it is in fact based on the acceptance of norms and rules which determine the rational and non-hostile interaction of individuals who could have different interests and values, but who also understand the possibility of maximizing reciprocal interests. What is claimed here is that horizontal processes of identity construction (resulting in so-called social identity) are more likely to shape societal forms of grouping, while vertical, top-down dynamics of identity construction are likely to shape communitarian forms of grouping. This is due to the fact that a community based on self-hood and sameness, because of its own nature, constructs its identity in an exclusive way, creating its image through confrontation with others.

However, as Weber outlined, these are only ideal types, and in real life societal socialization can give rise to aspects of communitarian socialization and vice versa (Weber 1922, 1980, vol. 1: 39). Each national society presents aspects of societal socialization and features derived from a sense of community. The problem is not the reality, but those theoretical approaches which refer to the identity of a society only in terms of a community of belonging, entry to which is necessarily considered strictly closed and where rules of admission are based on natural elements. In the EU, the debate over its rules of admission currently seems to be inclined towards a communitarian model (for example, the discussions on Turkey and its possible entry into the club). 


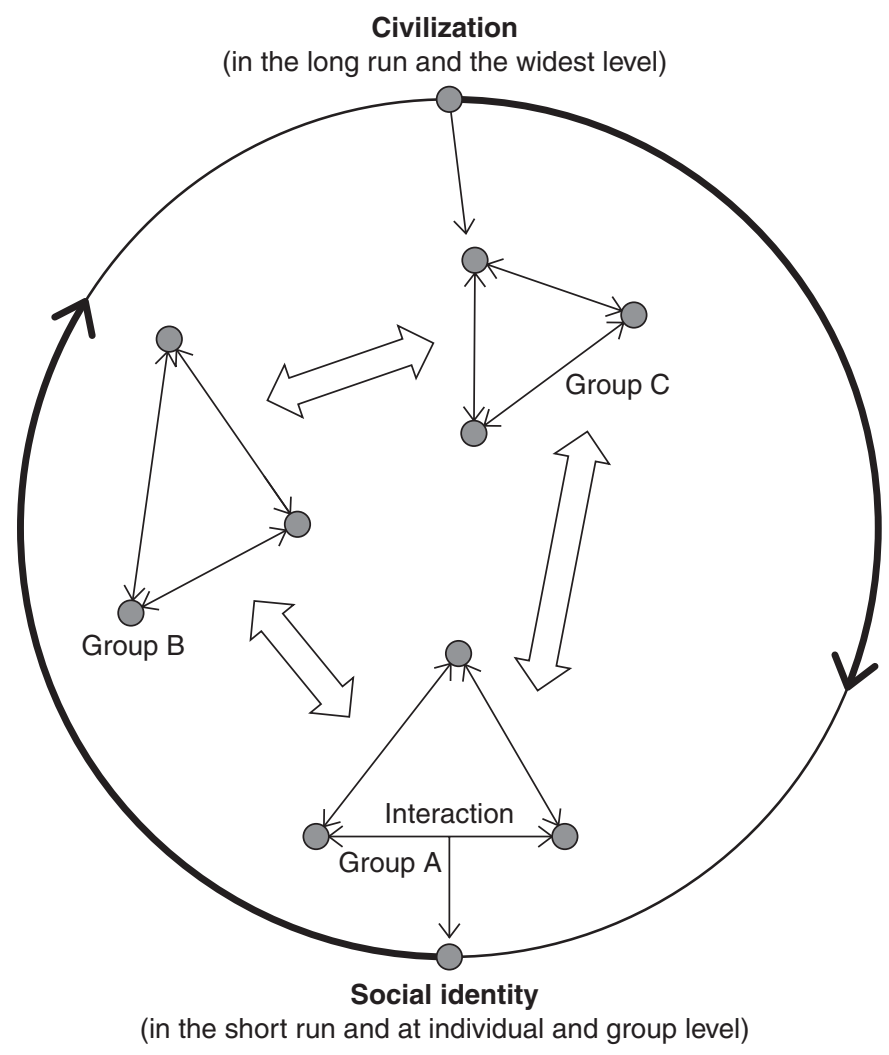

Figure 2.1 Dynamics of the process of identity construction (source: (C) Valeria Bello 2009).

This theoretical distinction therefore can be useful when analysing which one of the two identity construction processes is predominant in a territory. This distinction becomes operational through an analysis of different aspects, such as: the dynamics of identity construction (top-down or horizontal; emotional and structure-oriented, or rational and scope-oriented); entry requirements (natural elements or respect for internal rules); the degree of openness or closure of the group; the definition of borders (hard/closed or shifting borders); and the voluntary or involuntary motion of individuals towards conformity. A simple cross-tab can distinguish analytically between the two (see Table 2.1).

\section{What kind of identity construction is there at macro-regional level?}

In order to understand what kind of identity construction is possible at macroregional level, it is worth considering the European case, by recalling empirical 


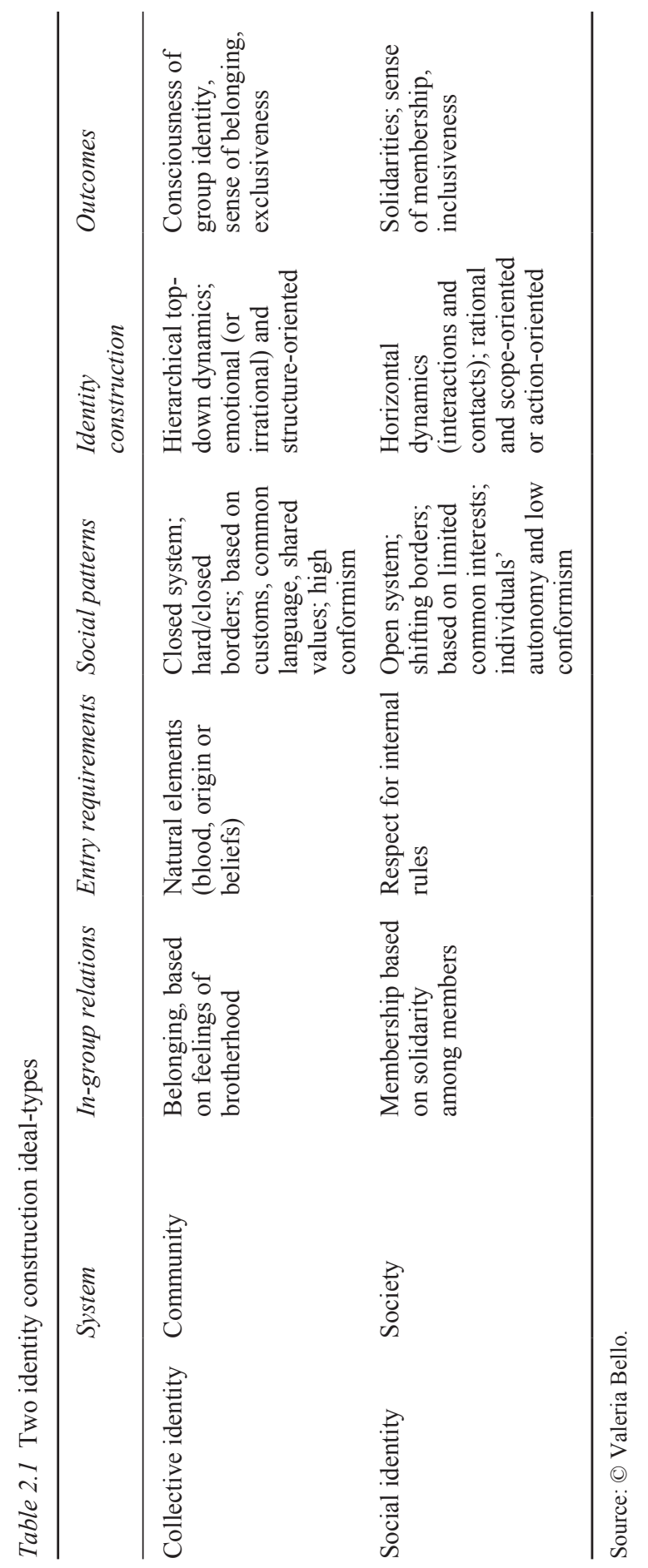


investigations and the results presented in the Asian, African and Latin American case studies in the relevant chapters of this volume. Regarding Europe, as is well known, most of the investigations that have been carried out on European identity show that a feeling of belonging to the EU is expressed only by a group of well-educated individuals who have lived in different European countries (Carey 2002; Diez Medrano 2003; Garcia Faroldi 2008; Ruiz Jimenez et al. 2004). However, all these research projects concerned people's identification with the EU, and considered whether people felt 'European' and supported the EU. These of course clearly involve collective forms of identity which are consciously maintained, and emotionally driven and structure-driven. Other studies, such as that of Hooghe and Marks (2004), clearly show that the development of a European identity is difficult where there is a strong sense of national community, because the EU is perceived as a possible threat. This confirms the belief that a strong national identity - based on communitarian socialization, emotionally driven and structure-oriented - is characterized by hard borders and is a closed system; therefore, connections with other systems, and the development of forms of solidarity with, or loyalty to, diverse groupings, are not possible. In fact, in this case the sharing of interests and values is considered to depend on feelings of brotherhood; it is emotional and not rational. Thus, I consider spontaneous dynamics of interactions to be more adequate identity construction mechanisms for a regional integration process than hierarchical attempts to shape a fixed image of commonality for people to identify with. The latter could actually come into confrontation with national collective identities, which are currently stronger. Thus, a regional identity can entail a social identity and not a collective one. Indeed, at such a level, with a vast territory and a large number of member states, it is difficult to imagine the possibility of common habits and shared values, while it is very simple to understand it as a society where there are common but limited interests, which can emerge through interaction and be maximized through cooperation. This is indeed the objective of regional integration processes.

Unfortunately, today people seem to give too much importance to a community of belonging, with the result that horizontal dynamics of identity construction are obscured and consequently underestimated. However, they have always taken (and still take) place, and in our age this phenomenon also concerns regional dimensions. At the European level, for example, we can refer to contacts through work, to increased mobility or to mixed families - couples with different nationalities (Bettin Lattes and Bontempi 2008; Garcia Faroldi 2008; Recchi 2005; Recchi and Nebe 2003). But, apart from interaction and contacts among individuals, is there any kind of actor that can contribute to this horizontal process of identity building? Each kind of institutional socializing agent should be excluded because of being involved in top-down dynamics of socialization. On the other hand, families can be socializing agents but only in a longterm perspective, after they have been socialized or have had interaction and contacts in the regional context. Other socializing agents that can effect horizontal processes of identity construction are: the media (mainly the free press) 
through socialization; and civil society through interaction. Therefore, the role of the public sphere is essential, as recognized by several scholars (Beyeler and Kriesi 2005; Eriksen 2005; Koopmans and Erbe 2004; Machill et al. 2006; Trenz and Eder 2004). However, civil society plays a more important role than the media in the construction of social identity: the media can be important only for the diffusion, but not for the construction, of social identity. Indeed, if we consider that social identity is created by the presence of limited common interests among members of a society, it is clear that the only collective actors likely to contribute to this process without putting into effect top-down dynamics are civil society associations and movements, as they are formed by groups of citizens. Therefore they can be relevant actors in the construction of a common interest in a broad territorial context. For example, in the EU they can contribute to policy making through the European Economic and Social Committee's activities or influence the decision-making process through the social and the civil dialogues. On these occasions, civil society associations, NGOs, advocacy coalitions and other lobby groups from all over Europe meet and discuss together what should be pursued at a European level. However, even outside the institutional framework, civil society's contribution is visible. In this light, the June 2008 protests by fishermen in Brussels can be considered very important, because people belonging to different member states banded together to reach a common interest. This event was anticipated in March 2005 by the 'Euro-demonstration', when 75,000 people from all over Europe marched in Brussels to defend employment and social rights in opposition to the Bolkestein directive. But the relevance of the fishermen's protest of June 2008 is that it was at first national (demonstrations started in May in France, Portugal, Spain and Italy as national protests) and then took on a supra-national dimension when the fishermen's associations, by realizing that they had a common transnational interest, decided to protest together. ${ }^{8}$ Thus, this was not the result of an initiative by an institutional actor, such as the European Trade Union Confederation (the organizer of the 2005 protests), but a spontaneous movement. Participants considered that together they were stronger and more effective than they would be if they protested alone in their national context and they understood that the relevant governing level was Brussels. Two important elements follow. First, there are categories of people who have started to feel the need to protest together against the European government. Not only do they recognize common interests even if they belong to different national contexts, but they also have shared aims. Moreover, they may have influenced other parts of the world, and may thus be considered a model for action. Second, these individuals have had contact with one another and have established a network that organized the protest. They have communicated and expressed the same interests, feelings and ideas transversally to other nations. However, the most important aspect is that they have conceived and performed a common action.

Now, even if the EU seems to be in question, what is really happening is that it has finally entered into society. Certainly, this has a consequence: once people become involved, they want to have a voice. If the EU finally reaches society, it 
is clear that, as in every democratic system, people may contest it and may dislike some of its policies. However, this does not mean that there is no identity in Europe; on the contrary, it may be just the beginning of a common identity. Identity does not mean blind trust in institutions when it is not intended as a prepackaged collective identity to be instilled down to the citizens.

In addition, when considering some other elements illustrated by the regional case studies included in this volume, it is worth highlighting the following points concerning the role that civil society plays in the process of identity construction in regional contexts. First, as far as the Asian case is concerned, as Gilson notes in this volume, the idea of a region 'serves as a useful geographical frame for these groups, but it may also be applied to justify certain values and a mythical-historical reference to a community of shared values'. This confirms the possibility of shared interests and values intended as the result of an interaction process at the regional level created through civil society activities. Second, regarding Africa, Godsäter and Söderbaum in this volume show that it is possible to see that, despite the different strategies adopted by civil society associations working at the regional level, those which engage within an interstate framework do so mainly to solve common problems, thus recognizing common interests despite internal conflicts. Thus at a regional level different actors can still recognize limited shared interests, even when conflict and internal rivalries exist at a more general mass level. Third, Saguier's case study below on Latin America shows that the only viable construction of shared interests is anchored in a common political ideology, which has indeed been the most unifying element in this region. Understood as collective identity formation, it is difficult for it - according to my reasoning - to create solidarities large enough to give rise to common identification in a supra-national institution at a regional level. This perhaps explains why in the only region where (most of the) countries share a language, construction of a regional identity seems unlikely. Indeed, Latin American regional integration, once considered to be among the most advanced, today seems weak compared with the other regional integration processes.

\section{Conclusion}

Civil society associations and movements try to advocate particular interests, which may be those of a specific category of people, such as fishermen or women. By coming together, groups of different nationalities can find common interests and can interact in such a way as to create the tools for constructing a social identity. Of course this regional social identity is limited and holds a particular meaning for each individual and each group (even national groups). For example, representatives of the European Economic and Social Committee (EESC) find that their initiatives are taken more seriously by the Council and the European Parliament when support for an agreement is very broad (Bello 2008). In this way, it is possible to see and create a real European interest. Even groups whose particular interests are contrary not only to those of other countries but 
within country groups themselves, still are able to perceive a common European interest. This shows that the borders of a European identity constructed through horizontal dynamics are inclusive, and makes it possible to obtain a broad consensus even between very different categories of individuals with very divergent interests.

As a final consideration, interaction within a regional context represents a horizontal process of identity construction; so it is likely to create an inclusive form of identity. Thus, regional integration processes based on inclusive identity types can take the form of open societies; therefore, they will not threaten the existence of national identities. In contrast, the existence of different national or local identities may depend on the survival of regional identity. Just as without the EU framework none of the European nationals could match America, China or India in a globalized world, other regional groupings such as South East Asia or Africa cannot hope to succeed in the face of competition by the great powers. Through the proposed perspective on the process of identity construction, civil society can play a very significant role.

\section{Notes}

1 I would like to thank the other editors of this volume and Juan Diez Medrano for their useful comments which enormously helped the development of this work. In addition I have benefited greatly from discussions with Livia Garcia Faroldi, whose friendship has been invaluable for my academic growth during these years. Naturally, none of these persons should be considered responsible for this work's deficiencies, which are only and wholly mine.

2 A sort of enlarged family group which can even cross the borders of groups, tribes, communities or countries.

3 For a general discussion on the concept of social identity see Jenkins (2008), while for a distinction between social identity and other notions see particularly the Handbook of Symbolic Interactionism (Reynolds and Herman-Kinney 2003).

4 Indeed, even the individual, if considered as a system (in Luhmann's reasoning), tries to give coherence to his/her actions and uses his/her own identity to control different roles in private and public life.

5 But this is not the case for a sense of belonging, which is a feeling and not a system of reference, and which can be a consequence of a collective identity but is not the identity itself.

6 By 'spontaneous' I mean what is not induced or created from above by dominant groups, political leaders or institutions.

7 I do not like to use concepts like ethnos, because I do not share the idea that there are natural elements composing identity; I also consider ethnos a reifying concept. So I prefer to use the one of 'imagined communities' proposed by Anderson (1983). Here, the concept ethnos is intended to refer to its 'common use' as a category of practice.

8 After this event, the protest spread to other places, such as Canada (10 June 2008) and Japan (18 June 2008).

\section{References}

Anderson, B. (1983) Imagined Communities. Reflections on the Origin and Spread of Nationalism, London: Verso. 
Bello, V. (2008) 'Europeanisation and Social Identity: An Interpretative Analysis Carried out on Italian Civil Society Representatives', paper presented at the 38th ISS World Conference, Budapest, 26-30 June 2008, and published in the Jean Monnet Working Paper series. Online. Available www4.soc.unitn.it:8080/poloeuropeo/content/e2611/ index_eng.html? (accessed 4 March 2010).

_ (2010) 'The EU's International Identity in African and Asian's Perspectives', in V. Bello, and B. Gebrewold (eds) A Global Security Triangle. European, African and Asian Interaction, Oxford: Routledge.

Berger, P. and Luckmann, T. (1966) The Social Construction of Reality, New York: Doubleday; trans. (1969) La realtà come costruzione sociale, Bologna: Il Mulino.

Bettin Lattes, G. and Bontempi, M. (2008) Generazione Erasmus? L'identità europea tra vissuto e istituzioni, Florence: Florence University Press.

Beyeler, M. and Kriesi, H. (2005) 'Transnational Protest and the Public Sphere', Mobilization, 10(1): 95-109.

Blumer, H. (1963) 'Society as Symbolic Interaction', in A. Rose (ed.) Human Behavior and Social Processes, Boston: Houghton Mifflin, 179-192.

_ (1969) Symbolic Interactionism. Perspective and Method, Englewood Cliffs, NJ: Prentice-Hall.

Brubaker, R. and Cooper, F. (2000) 'Beyond Identity', Theory and Society, 29(1): 1-47.

Calhoun, C. (1997) Nationalism, Minneapolis: University of Minnesota Press.

Carey, S. (2002) 'Undivided Loyalties. Is National Identity an Obstacle to European Integration?', European Union Politics, 3(4): 387-413.

Castells, M. (1997) The Power of Identity, Oxford: Blackwell.

- (2002) 'La costruzione dell'identità europea', Foedus, 3: 15-23.

Cerutti, F. and Lucarelli, S. (eds) (2008) The Search for a European Identity, London: Routledge.

Checkel, J. (1998) 'The Constructivist Turn in International Relations Theory', World Politics, 50(2): 324-348.

- (eds) (2007) International Institutions and Socialization in Europe, Cambridge: Cambridge University Press.

Davidshofer, S. (2005) 'The European Union and the United Nations as "Natural Partners". Constructing European International Identity through Security: EU Crisis Management and the UN', paper presented at the annual meeting of the International Studies Association, Hilton Hawaiian Village, Honolulu, Hawaii. Online. Available www.allacademic.com/meta/p70813 index.html (accessed 4 March 2010).

Delanty, G. and Rumford, C. (2005) Rethinking Europe. Social Theory and the Implications of Europeanization, London: Routledge.

Deutsch, K. W. (1954) Political Community at the International Level: Problems of Definition and Measurement, New York: Doubleday.

- (1957) Political Community and the North Atlantic Area: International Organization in the Light of Historical Experience, Princeton, NJ: Princeton University Press.

Diez Medrano, J. (2003) Framing Europe. Attitudes to European Integration in Germany, Spain and the United Kingdom, Princeton, NJ: Princeton University Press.

Dubar, C. (1998) Trajetórias sociais e formas identitárias: alguns esclarecimentos conceituais e metodológicos. Educ. Soc. [online]. 1998, vol. 19, n.62 [cited 2009-04-08], pp. 13-30. Available www.scielo.br/scielo.php?script=sci_arttext\&pid=S0101-733019 98000100002\&lng=en\&nrm=iso (accessed 4 March 2010).

Eder, K. and Spohn, W. (2005) Collective Memory and European Identity, London: Ashgate. 
Eriksen, E. O. (2005) 'An Emerging European Public Sphere', European Journal of Social Theory, 8(3): 341-363.

Etzioni, A. (1965). Political Unification, New York: Holt, Rinehart and Winston.

EU Commission (2001) 'European Governance. A White Paper', COM 364/2000. Online. Available http://eur-lex.europa.eu/LexUriServ/site/en/com/2001/com2001_0428en01. pdf (accessed 4 March 2010).

Farrell, M., Hettne, B. and Van Langenhove, L. (eds) (2005) Global Politics of Regionalism. Theory and Practice, London and Ann Arbor, Mich.: Pluto Press.

Garcia Faroldi, L. (2008) Construyendo Europa. Las redes sociales en la difusion de actitudes e identificaciones hacia Europa, Madrid: Centro de Investigaciones Sociologica.

Gellner, E. (1983) Nations and Nationalism, Ithaca, NY: Cornell University Press.

Giddens, A. (1991) Modernity and Self Identity, Self and Society in the Late Modern Age, Stanford, Calif:: Stanford University Press.

Grimm, D. (1995) 'Does Europe Need a Constitution?', European Law Journal, 1(3): 282-303.

Haas, E. B. (1958) The Uniting of Europe: Political, Social and Economic Forces 1950-1957, Stanford, Calif.: Stanford University Press.

— (1960) 'International Integration: The European and the Universal Process', International Organization, 4: 607-646.

- (1964) Beyond the Nation-State: Functionalism and International Organization, Stanford, Calif.: Stanford University Press.

Habermas, J. (1995) 'Comment on the Paper by Dieter Grimm: Does Europe Need a Constitution?', European Law Journal, 1(3): 303-3071.

- (1998) Die Postnationale Konstellation: Politische Essays, Berlin: Suhrkamp Verlag; trans. (2001) The Postnational Constellation: Political Essays, Cambridge: Polity Press.

Haller, M. (ed.) (2000) The Making of the European Union, Heidelberg: Springer.

Hooghe, L. and Marks, G. (2004) 'Does Identity or Economic Rationality Drive Public Opinion on European Integration?', Political Science and Politics, 37(3): 415-420.

Huntington, S. P. (1996) The Clash of Civilizations and the Remaking of World Order, New York: Touchstone.

Jenkins, R. (2008) Social Identity, London and New York: Routledge.

Katzenstein, P. (1996) The Culture of National Security: Norms and Identity in World Politics, New York: Columbia University Press.

Koopmans, R. and Erbe, J. (2004) 'Towards a European Public Sphere?', The European Journal of Social Science Research, 17(2): 97-118.

Lucarelli, S (2007) 'The European Union in the Eyes of Others: Towards Filling a Gap in the Literature', European Foreign Affairs Review, 12(3): 249-270.

Luhmann, N. and De Giorgi, R. (1991) Teoria della società, Milan: Franco Angeli.

Manners, I. and Whitman, R. (2003) 'The "Difference Engine": Constructing and Representing the International Identity of the European Union', Journal of European Public Policy, 10(3): 380-404.

Machill, M., Beyler, M. and Fischer, C. (2006) 'Europe-Topics in Europe's Media. The Debate about the European Public Sphere: A Meta-Analysis of Media Content Analyses', European Journal of Communication, 21(1): 57-88.

Miller, D. (1995) On Nationality, Oxford: Oxford University Press.

Olsen, J. (2007) Europe in Search of Political Order, Oxford: Oxford University Press.

Recchi, E. (2005) 'Migrants and Europeans: An Outline of Free Movement of Persons in the EU', AMID Working Paper series, 38/2005. Aalborg East: Academy for 
Migrations Studies in Denmark. Online. Available www.amid.dk/pub/papers/ AMID_38-2005_Recchi.pdf(accessed 4 March 2010).

Recchi, E. and Nebe, T. M. (2003) 'Migration and Political Identity in the European Union: Research Issues and Theoretical Premises', in PIONEUR Working Paper No. 1, July. Alicante: University of Alicante. Online. Available www.obets.ua.es/pioneur/ bajaarchivo_public.php?iden=39 (accessed 4 March 2010).

Reynolds, L. T. and Herman-Kinney, N. J. (eds) (2003) Handbook of Symbolic Interactionism, Oxford: AltaMira Press.

Ruiz Jimenez, A. M., Górniak, J. J., Kandulla, M., Kiss, P. and Kosic, A. (2004) 'European and National Identities in EU's Old and New Member States: Ethnic, Civic, Instrumental and Symbolic Components', European Integration Online Paper, 8(11). Online. Available http://papers.ssrn.com/sol3/papers.cfm?abstract_id=570601 (accessed 4 March 2010).

Scartezzini, R. (2004) Stati, nazioni, confini, 3rd edn, Rome: Carocci.

Scharpf, W. (1999) Governing Europe. Effective and Democratic?, Oxford: Oxford University Press.

Sedelmeier, U. (2003) 'EU Enlargement, Identity and the Analysis of European Foreign Policy: Identity Formation Through Policy Practice', RSC Paper, n. 2003/13. Online. Available http://ideas.repec.org/p/erp/euirsc/p0080.html (accessed 4 March 2010).

Simmel, G. (1890) Über sociale Differenzierung, Leipzig: Duncker \& Humblot; Italian trans. (1995) La differenziazione sociale, Bari: Laterza.

Smith, A. (1986) The Ethnic Origins of Nations, Oxford: Blackwell.

Smith, K. E. (2008) European Union Foreign Policy in a Changing World, Cambridge: Polity Press.

Tajfel, H. and Turner, J. C. (1986) 'The Social Identity Theory Of Inter-group Behaviour', in S. Worchel and L. W. Austin (eds) Psychology of Intergroup Relations, Chicago: Nelson-Hall.

Trenz, H. J. and Eder, K. (2004) 'The Democratizing Dynamics of a European Public Sphere', European Journal of Social Theory, 7(1): 5-25. Online. Available http://est. sagepub.com/cgi/content/abstract/7/1/5 (accessed 4 March 2010).

Turner, J. C. (1982) 'Toward a Cognitive Redefinition of the Social Group', in H. Tajfel (ed.) Social Identity and Intergroup Behavior, Cambridge: Cambridge University Press.

Weber, M. (1922) Wirtschaft und Gesellschaft, Mohr: Tübingen; Italian trans. (1980) Economia e società, Milan: Edizioni di Comunità.

Wendt, A. (1999) Social Theory of International Politics, Cambridge: Cambridge University Press; Italian trans. (2006) Teoria sociale della politica internazionale, Milan: Vita e Pensiero.

Wenger, E. (1999) Communities of Practice. Learning, Meaning and Identity, Cambridge: Cambridge University Press.

Whitman, R. (1997) 'The International Identity of the EU: Instruments as Identity', in A. Landau and R. Whitman (eds) Rethinking the European Union: Institutions, Interests and Identities, Basingstoke: Macmillan.

Wimmer, A. (2002) Nationalist Exclusion and Ethnic Conflict. Shadows of Modernity, Cambridge: Cambridge University Press. 


\title{
3 Organised civil society and political representation in the $\mathrm{EU}$ arena
}

\author{
Carlo Ruzza
}

\section{Introduction}

As has often been noted, the European Commission is a bureaucracy with unique traits. It can be conceptualised and studied as a bureaucracy, and as such it shares many of the distinctive traits of other bureaucracies in terms of its problems, ideologies, constraints, strategies, and relations with its political masters. Thus, considerations of budget maximising and bureau shaping are as relevant for the EU Commission as for other bureaucracies. It is, however, a very distinctive civil service as several of its functions are unique, and so is its supranational institutional environment. Thus, heightened concerns for political legitimacy are distinctive. As in other civil services, reliance on and inclusion of civil society groups can address some of its problems, but in a distinctive way. This chapter will focus on the relations between civil society and the Commission and examine to what extent they are coloured by the distinctive characteristics of this institution, and to what extent the changing features and roles of civil society formations reflect the growing general importance that civil society is acquiring in the EU institutional environment. However, to the extent that the EU Commission reflects broader dynamics taking place in the European public sector, we will strive to generalise beyond the specific test case of the EU.

The European Commission, like other public bodies, is involved with civil society groups in various capacities: among the functions frequently cited in the literature, civil society representatives are consulted as providers of technical and scientific expertise, channels for collecting information on the preferences of specific groups or causes, and recipients of funds for service delivery. However, we will argue that the full set of roles that civil society can play is broader. The specific reasons, and the specific motivational factors underlying the relations between civil services and civil society groups, are likely to change over time and in different places. With specific reference to the European Commission, we would like to emphasise the distinctive roles played by issues of representation. After a brief review of the main functions of civil society groups in policy arenas, and consideration of their specificity at EU level, we will focus on representation. We argue that a set of recent changes in the structure of civil society organisations has facilitated these functions and made them more politically salient. 


\section{The policy role of civil society and the EU level}

Interviews with policy makers in a variety of different administrative contexts suggest that the most important reason for including all civil society groups in policy-making contexts is to acquire information (Walker 1991). Good policies are based on appropriate technical, social and political information. Information is costly and it can become scarce and biased in an under-resourced state. Funds to acquire information through scientific research are limited, and powerful economic actors can often provide relevant, but not unbiased, information. Civil society groups, through their scientists and through their grassroots bases, can often provide information that counterbalances that information provided by lobbyists and can complement the often limited understanding of social and territorial issues in specific contexts that would be difficult and expensive to study. In a constantly changing political and social environment, public sector activities are aimed at improving the social conditions of a population with frequently changing needs. Empirical research shows that civil society formations are valued primarily for the quality of the information they can provide. For instance, an EU document on civil society notes: 'NGOs have a duty to demonstrate that they have the expertise, management systems and internal quality control systems appropriate to the work they are undertaking on behalf of the Commission' (European Commission 2000: 7).

This fact has induced several organisations to develop specific policy, technical, sociological and administrative skills. For instance, at both local and supranational level, institutionalised environmental groups are often highly specialised and possess specific knowledge about complex sectors such as transport, agriculture or energy (Rootes 2007, 2008). At the EU level, information is particularly valued because of two main factors. One is the relatively limited size of the EU civil service and its limited funds and powers to acquire original and pertinent information to aid decision making. The second is that the ideological and administrative fragmentation of the European Commission makes scientific and technical expertise traditionally highly controversial (Michelmann 1978). It is then not infrequent that different directorates general (DG) will prefer to use civil society expertise that they can trust as being sympathetic to their values and policy orientations.

A related factor is that the participation of civil society groups can foster processes of policy learning which are useful for the entire public sector (Jachtenfuchs 1996). Policy learning can be facilitated by the existence of a thick associational inter-organisational field able to produce debating spaces in which deliberative forms of political participation can take place. These spaces do not necessarily need to be consensual and always result in shared decisions. State actors often argue that their ultimate decision-making power does not diminish the information-providing, preference-aggregating and preference-redefining benefits of involvement in debating fora. Thus the informational contribution of civil society organisations includes a better provision of information on which to base policies, and it can stimulate better decision making. Nonetheless, at the 
EU level, policy learning becomes feasible when there is ideological congruity between scientific and technical experts involved in consultations and the ethos of particular DGs. For this reason it is more likely that environmental experts consulted by DG Environment will hold environmentalist values, or that experts on issues of racial discrimination consulted by the anti-discrimination unit of DG Social Affairs will equally hold strong anti-racist values.

The joint need to acquire information and process it correctly is particularly pressing in some areas, such those of services to ethnic constituencies, poverty reduction, and local community self-help groups, because such social information is frequently changing and not sufficiently known in policy-making circles (Rosenbaum 2006: 46). Because it is in these areas that NGOs often concentrate, their contribution is essential. Likewise, advocacy contribution and service delivery skills in areas related to gender issues are important when the process involves different levels of governance which have institutionalised antidiscriminatory practices selectively. Rosenbaum points, for instance, to the case of international donor organisations which use civil society groups for that purpose (Rosenbaum 2006: 47). Similar considerations apply to supranational entities such as the EU in relation to some member states (Ruzza 2004).

The inclusion of civil society and its contributions to policy making acquire a special role at EU level because of its distinctive governance-based institutional architecture. This has a relatively weak centre within which member states attempt to effect policy change in European institutions characterised by limited decision-making power, a constantly changing institutional architecture, limited political legitimacy, and often poor coordination capacity (Ruzza 2004). In this situation, all interest groups - including public ones - have an important role in supplementing a weak policy process and making up for limited implementation effectiveness. But it also becomes imperative to overcome the obviously predominant role of economic interests above all others. For this reason, all European institutions have for many years emphasised and supported the aggregation, professionalisation, institutionalisation and inclusion of civil society groups (Mazey and Richardson 1994; Greenwood and Aspinwall 1998).

Civil society organisations also interact with the public sphere - either in terms of media campaigns or occasionally in terms of demonstrative action and they can reshape the policy needs and requests of salient groups in the population. Civil society organisations then articulate the connections between politics and society, making sure that socially relevant issues are translated into issues in the political arena. They have in this sense an innovative role often connected with the work of social movement organisations. This role may benefit public services by helping them to reach out to public opinion and articulate some of its policy choices, possibly those coordinated with civil society actors. This is a distinctive preoccupation of the EU institutional framework, and the Commission in particular (Schmitter 2000). All civil services have an increasing awareness of the necessity to be positively evaluated by public opinion, particularly in times of anti-political reactions to a generalised perception of bureaucratic inefficiency, organisational lack of accountability, 
institutional fragmentation of the public sector and resulting low quality of public services. However, these perceptions are even stronger in the European Commission, whose employees at all levels of the hierarchy are painfully aware of the negative image they elicit in several member states (Cini 1996; Hooghe and Robert Schuman 1998).

Civil society organisations can also facilitate the interaction between the public sector and its users. Much behaviour considered problematic, which the public sector is asked to address, is rooted in incorrect information or otherwise problematic lifestyles. A few examples should suffice. Environmental compliance with standards of recycling is, dependent on the willingness of citizens to comply with municipal environmental regulations. Public sector policies that enlist the support of environmental associations are more likely to be effective, because a fund of energy and activism becomes available. Furthermore, as previously noted, additional political legitimacy is acquired. The same consideration - the importance of enlisting civil society support in projects for lifestyle change - applies to anti-discrimination or health policies, where the resource base and persuasion ability of groups is often essential. A vibrant political-associational space can provide non-conventional agonistic spaces for channelling scientific or technical expertise in the public sphere. Associated with this approach are mechanisms that facilitate the transposition of practices from the associational to the political sector.

Associations can provide alternative chains of representation up and down the ladder of different levels of governance. This constitutes a new and important form of political participation. Public sector administrations are able to use civil society to connect to different levels of governance: for instance, to coordinate choices with regions with similar characteristics in the context of EU-level fora, or to represent their anti-discrimination or environmental concerns to EU institutions with the help of EU-level public interest groups. Much of the work on political participation has been done with an implicit or explicit reference to a model of a self-contained nation-state. This takes the political boundaries of a state as the main if not the only reference for defining political strategies, and it uses the nation-state as the society of reference. This is no longer tenable in a multi-level governance structure such as the EU.

In an integrated Europe, mechanisms for the transmission of citizens' preferences across levels of governance are increasingly essential, as the debate on the limits of democracy in the European Union indicates. New forms of consultation can integrate the governance role of multi-level associations, providing an alternative chain of representation able more effectively to represent the preferences of weaker groups in the population - for instance, disfranchised clandestine migrants, or minorities which are scattered territorially and therefore not fully represented by democratic institutions. Related to this important coordinating role that civil society groups can perform to benefit the public sector are transnational forms (that is, not only supranational) of political representation on issues decided at higher levels of governance but which have a direct impact on specific sectors of the population (Keck and Sikkink 1998). 
Through civil society associations, and often with the involvement of administrators at local levels of governance, marginalised constituencies can engage in processes of venue shopping - processes otherwise reserved for powerful business actors. Both civil society groups and interest groups interacting with the political environment face a multiplicity of venues, and they increasingly engage in venue shopping. This opportunity does not go unnoticed by members of civil society with the same political ideologies who act in a coordinated manner across different institutional realms and are often perceived as a distinctive constituency. In this context references have sometimes been made to 'femocrats' or 'envirocrats', which indicate, respectively, feminist or environmentalist activists in institutional positions, regardless of their specific institutional affiliation. These concepts are certainly not irrelevant to pockets of institutional activists within the European Commission or within the European Parliament with whom transversal advocacy coalitions have emerged over the years which combine the EU institutional framework and civil society groups (Judge 1992).

The increasingly frequent steering mechanisms based on soft -laws partially developed outside the compelling authority of states often need to rely on consensus-seeking coordination, which may take place in multi-level deliberative fora. In these contexts, sectors of the civil service and civil society can work in tandem to pursue shared goals - this is not unusual at EU level where reliance on soft laws is in part mandated by a weak institutional framework (Smismans 2004).

Grassroots civil society associations not only have better social and factual information because they are closer to their base, they can also provide better services because they have advantages of access; they are relatively freer from the imperatives of profit that mark commercial organisations; and they have a stock of additional social resources that they can channel to their bases through their (not uncommon) roots in affluent conscience constituencies - for instance, volunteers who help migrants obtain social services to which they are entitled but which would otherwise not be used because of limitations in social capital. At the EU level this is relevant, for instance, with reference to the Raxen network in the context of information on issues of discrimination in member states. This is important in contexts in which the public sector simply cannot afford to support weaker groups in the population. One thinks of the educational initiatives that civil society organises for underprivileged youth, some of which are supported by EU programmes. Civil society organisations and related experts and advocates also engage in the monitoring of policy-making processes and of implementation compliance. This is particularly important in areas where the consequences of defective implementation affect socially weak groups - for instance, in regard to issues of racism, environmental justice or gender mainstreaming.

One of the key functions of representative institutions is the aggregation of preferences, which is related to how the representational process is constructed. However, processes of preference aggregation are often not satisfactory in contemporary society. Civil society produces an additional and alternative process 
of aggregation of preferences within citizens' associations - a process often based more on deliberative aggregation and which can compensate for some of the shortcomings of the electorally based aggregations. Finally, a related process of triangulation between national and supranational institutions can provide the public sector with information and political opportunities that would otherwise be difficult to obtain. In this context relations between civil society groups in member states and at the EU level provide an additional channel for monitoring and improving governance arrangements. To the extent that a transition to an increasing use of governance structure is taking place, the role of civil society, and particularly organised civil society, is increasing.

To summarise, it has been argued that the public sector increasingly needs civil society because it provides benefits that would otherwise scarcely be available. These include public sphere communication, information acquisition and diffusion, aggregation of preferences, policy improvement through deliberative policy learning, involvement in governance structures and the ability to represent public sector users at various territorial levels, transnational advocacy and venue shopping for better policies and resources. All these benefits are available to the extent that different types of civil society organisations can be involved and successfully integrated in collaborative projects with each other and in relation to the European and national public sectors. This depends upon successful processes of institutionalisation of civil society which currently characterise the sector, and which will be discussed below. First, however, some clarification of the issue of representation is needed.

\section{Representation, the public sector and the European Commission}

Political representation, as the activity of (re)presenting opinions and interests to the policy-making process, can be carried out by representatives holding elected office or by others. Representation can take place in several arenas. While democratic theorists often focus on the activities of office holders in democratic arenas, representation activities by interest groups of different kinds are increasingly the focus of analysis. Their activities are examined in a broad set of arenas - including EU institutions. They present some of the same organisational and political dynamics studied by theorists of democratic representation. The literature on representation in such varied contexts has grown in recent years and has often focused on the representative activities of associations, social movements and other informal groups. These social formations experience the same tensions that occur in elected institutions, such as the tensions between acting as delegates or as trustees. The multiple meanings of the concept of representation and the related internal tensions apply to all of the various arenas and agencies engaged in representative activities.

However, as Pitkin (1967) and others have pointed out, the contexts in which the concept of representation is deployed colour which dimensions are more salient. Prevalent political practices make different usages of the concept of 
representation more or less relevant and specify its analytical and normative context. In this sense, processes such as the growing relevance of supranational integration and the prevalence of governance structures have broadened what is topical in relation to issues of representation. It is therefore necessary to identify and discuss issues connected to representation, particularly issues of transparency, openness, accountability and representativeness, and their implications at EU level. They have an impact on issues of cooptation by public authorities including the EU Commission. In addition, in recent years the literature has emphasised that there is an associational form of representation in the public sphere - conceptualised as an increasingly important arena of policy shaping that complements forms of political representation in policy arenas. The specific public sphere role of civil society formations also needs to be examined.

In both cases, a broader concept of representation needs to be employed. Briefly, the contention here is that civil society behaves in the public sphere and in policy circles as a representative of sectors of the population that would otherwise be disfranchised, either because of their limited access to voting entitlement, as in the case of clandestine migrants, or because of educational or resource limitations on their capacity for social citizenship (Bonnett 1993; Plotke 1997; Young 1997; Warren and Castiglione 2004; Rehfeld 2005; Urbinati and Warren 2008). However, a reverse process is also taking place. When civil society is recruited to publicise specific constitutionalised values and practices, for instance anti-discriminatory behaviour or environmental norms, and thereby to affect lifestyles, it acts as a representative of the public sector towards specific constituencies (Ruzza 2008a).

Following Rehfeld (2005: 6), representation activities can be characterised in terms of the identity of representatives (who have to be members of a qualified recruitment pool); a selection agent; the functions required from the representative; and the decision rules utilised to select a particular representative. In the case of advocacy associations, the selection agents - often civil servants - select whom to consult and therefore endow with a type of representativeness. They may select business lobbies and NGOs as members of distinct but differently relevant communities of representatives. They may select among civil society networks of advocacy organisations according to a set of decision rules which could ideally include codified values such as 'internal democracy, openness, transparency, accountability, representativeness of the NGOs' constituency' (European Commission 1995). They also select representatives on the basis of their perceived ability to perform a set of functions. Among the various functions that public and private interest groups could perform, Urbinati emphasises the functions that the representative performs as an advocate. As Urbinati points out, conceiving the representative as an advocate "helps to highlight the two main political functions of representation, as a means both for expressing political opinions and choices and therefore exercising self-government, and for resisting exclusion and therefore achieving security' (Urbinati 2000: 761).

Policy-making institutions such as those governments which have established a 'compact' with the civil society sector, or such as the European Commission, 
have issued several key documents which implicitly and explicitly articulate the view that the activities of public interest groups serve to redress the imbalance present in a system of consultation that excludes or limits diffused interests from proper representation. And they have similarly stressed the importance of nonstate actors in providing information useful to the policy-making process. In this sense, the inclusion of advocates from civil society has a complex purpose. Organised civil society performs functions of legal advocacy, and more broadly policy pressure. In order to do so, it is often able to employ already qualified personnel, such as legally trained experts who, as they focus on specific cases, and therefore provide general information, also furnish representation for a class of individuals. As noted, this complex function is particularly valuable when it is performed on behalf of groups that are weak in the electoral arena. An awareness of this weakness has permeated several EU documents on civil society (European Commission 2000; Ruzza 2006). Awareness of the importance of civil society in the public sphere has equally permeated the Commission, which now has a growing understanding of the need for the European project to be better organised in that context (European Commission 2006). For instance, a Commission document notes

the role of NGOs in representing the views to the European Institutions of specific groups of citizens (such as people with disabilities, ethnic minorities) or on specific issues (such as the environment, animal welfare, world trade). In particular, many NGOs have an ability to reach the poorest and most disadvantaged and to provide a voice for those not sufficiently heard through other channels.

(European Commission 2000)

This view of civil society's role as providing a voice for the excluded and information for better policies is the standard that recurs in interviews with civil society. It is implicitly held by public opinion and it is echoed in scholarly work.

The informational contribution of civil society is connected to the broader form of representation we have described not only because the policy process needs information that the representative process in the legislature might not provide adequately; it is even more important when there are no other elements elsewhere in the policy process to supplement and round out civil society's contribution. One such element would be to conceptualise the civil service as a potential channel of representation. The role of civil society would become particularly important when the deficient representation of socially excluded groups in the legislature is not compensated by their presence and prominence in the public sector. This is what Stevens (2009) argues with reference to gender representation in the EU Commission. Poor representation of ethnicity and gender within EU institutions is well documented (Woodward 2008). In view of this factor, while Stevens argues that bureaucrats should make up for the deficiencies of representation in the legislature (Stevens 2009: 121), an equally relevant strategy would be better inclusion of civil society. 
If the inclusion of civil society can provide the informational, aggregative and representational benefits that have been described - benefits that can be integrative but also additional to other forms of public sector organisational model - still to be addressed is the issue of whether, despite the limitations of civil society organisations, which EU Commission documents do not fail to identify and emphasise (see for instance European Commission 1993), one can be optimistic as to their capacity to deliver. Also required is an examination of what mix of forms of involvement and types of organisations involved can best maximise the contribution of civil society. Discussion will then turn to the main types of organisations in the sector, what developments have marked their performance, and how they can interact and integrate their functions. We will argue that their role is differentiated across the different types of formations that make up civil society, and that although often in internal conflict, as a field of interacting organisations they complement each other (Warren and Castiglione 2004). Civil society conceptualised as an organisational environment can then be seen to be able to address the issues of transparency, accountability, internal democracy, informational effectiveness and policy delivery efficacy advocated by several civil services, including the Commission (European Commission 1995).

\section{Changes in the structure of civil society and relations with the public sector}

We wish to argue that a process of isomorphism is taking place whereby civil society organisations come to share some of the same views, develop policy competences and acquire both representational and service delivery skills. However, at the same time enough variety persists in the sector to mean that a range of civil society formations are needed to fulfil the functions that policy makers emphasise and that have previously been listed. Representational activities are typically performed by institutionalised social movements such as advocacy groups, citizens' advice bureaux or public pressure group representatives. Service delivery functions are typically performed by third sector organisations. Discussion of the relations between these two areas will illustrate the benefits of a unified concept of civil society in relation to the public sector.

Representational civil society addresses the public sphere. This is a relatively recent and topical concern which gives a new meaning to the concept of civil society (Seligman 1992). It moralises and politicises certain issues of importance to particular populations. It exercises policy pressure through a variety of means ranging from threats of disruption or negative campaigns by social movement groups to providing information to policy makers, and so on. Focusing on these functions contextually in relation to a broader concept of civil society can add new insights into how the political system as a whole interacts with non-state actors.

In contrast, service delivery activities are increasingly staffed by volunteers sensitive to the same social movements that are currently prominent in advocacy activities. In Italy, for instance, after the collapse of mass protest by the 'new 
social movements' of the 1980s, ex-activists assumed important positions in the voluntary sector, bringing an understanding of the importance and techniques of political communication and more generally of politics. The sector split between a secular and a religious wing, both shaped by the entry of disillusioned activists but also by their interest in influencing political change (Ranci 2006: 29-35). It addressed its historical constituencies such as women, gays and minorities by catering to their welfare demands, but no longer only in terms of enhancing their social and political identities and voicing political demands. This significantly altered the social movement sector, further reinforcing its institutionalisation through the impact of a flow of public resources and increased social acceptance of its service delivery role.

The social movement background of many volunteers also means that they are relatively comfortable with, and knowledgeable about, the workings of political communication and advocacy tactics, which they deploy by engaging in broad-mix civil society coalitions to advance demands for funds, recognition and public policy change. Similar changes have been observed in several EU countries and in the US, where the political role of the sector has increased while the number and scope of other types of civic groups have decreased (Skocpol 2003). Thus advocacy and service delivery activities are interrelated, and a broad concept of civil society gives better purchase on the full range of activities of civil society formations. Nonetheless, for analytical purposes, I now discuss the advocacy sector of civil society and the service delivery sector in relation to their contribution to the public sector. I briefly review he contributions of social movements, citizen groups and coalitions, arguing that while their distinctiveness is obvious, they should be studied under the common umbrella of their capacity to represent and serve their constituencies. Then discussed are third sector associations, with an emphasis on their contribution to the limited resources of the public sector. It is posited that these roles are often complementary and at times overlap; and that, in the context of public sector dynamics, forms of consultation and inclusion in policy making are often interrelated with service delivery activities. These are all part of civil society's various contributions - in particular to disadvantaged social groups. Furthermore, this integration limits and compensates some of the shortcomings of civil society, as noted by the European Commission in its evaluations of the sector.

I argue that the Commission's concerns about the quality of information are addressed by the growing expertise of many public interest groups, if not by social movement organisations. Concerns about the internal democracy and representativeness of civil society are potentially addressed by large platforms of social NGOs with standardised leadership election procedures, if not by charismatic social movements. On the other hand, social movement organisations provide a grassroots base and connections to movement groups at various levels of governance. They provide a way to reach specific sectors of the population, impact their knowledge and lifestyles, and achieve consensus. The NGOs' service delivery sector provides a way to address specific service delivery needs that other state institutions find difficult to address. Thus while not all civil 
society groups satisfy all the Commission's criteria for effective and normatively approved inclusion, the overall institutional environment of civil society can provide a positive and much-needed contribution to political representation in a governance context. I now review the two main branches of civil society: advocacy and service delivery, in terms of their contribution to the Commission's values of openness, internal democracy, transparency, and efficacy.

\section{The advocacy domain and the public sector}

The advocacy domain comprises a set of organisational formations that relate to the public sector. As mentioned, these include institutionalised social movement groups, but also less formal groups such as ad hoc grassroots coalitions, citizens' groups and broader multi-purpose umbrella groups or advocacy coalitions. To discuss this sector, it is useful to start with some reflections on the concept of a social movement. The advocacy sector is staffed by personnel who make a donation of energy, time and often personal resources in the name of idealistic causes. At any point in time the range of social causes for which this donation is available is limited and they are often connected to concerted attempts at social, political and cultural change - attempts embedded in networks of personal and organisational relations that are often classified as social movements.

Nonetheless, it is necessary to note the ambiguity of the concepts of social movement and the transformation of the related organisations, which form some of the main components of advocacy-oriented civil society. The concept of the social movement has received substantial scholarly attention. If in earlier decades the distinctive trait of social movements was their contentious repertoire of actions, this is no longer necessarily the case - at least not exclusively, and particularly not at the EU level. I wish to argue that processes of transformation of social movements are changing the profile of civil society and making it more readily integrated into the EU environment.

Social movements are to a large extent the historically shaped outcomes of processes of nation building and state building (Tilly 1978, 1984). Processes of internationalised governance are therefore likely to affect the form assumed by a social movement. While the political category of social movement is typically defined in terms of political protest at the national level, it takes on a different role once transferred to the international and supranational arena; and this, as Marks and McAdam (1996) argue, may require the revision of its conceptual definition when studied in a different political environment outside the confines of the nation-state. However, revision is useful even within the boundaries of states, because movements increasingly interact in multi-level governance structures with supranational aggregations, of which the EU is probably the most successful example.

In a political system based on shared sovereignty, consensual policy making made necessary by weak decision-making powers, and horizontal and vertical dispersion of authority, the social movement form lacks the clear target offered by the Westphalian state in all its articulations. This is the case even if the state's 
authority is considered not as weakened but as merely redefined as an economysteering role (Weiss 1998). These changes then require a redefinition and a broadening of the environment in which calculations of political opportunity are made. Such broadening makes calculations of the cost-effectiveness of protest actions more difficult, and the identification of targets more variable. To be expected in such a context is extensive venue shopping, and the targeting of action forms on the specific features of different venues.

Second, besides aiming at policy change, social movements attempt to promote social change through strategies of cultural diffusion to which elected representatives are expected to respond. However, if the confines of movements' cultural efforts are broadened, this will have an impact on predicting the direct policy consequences of their action, and it will also create expanded cultural opportunities (McAdam and Rucht 1993). This has implications for calculations of focusing on convergent frames across national boundaries but also across types of political formations. Broader convergences may become possible and necessary in a broader political environment. In a situation of weak decision making and negotiated governance with non-state actors, frame convergence with potential allies such as other civil society organisations becomes essential. This applies to a variety of organisations able to develop convergent frames, but it applies in particular to organisations with substantial and growing political importance such as public interest groups and third sector organisations.

A convergence of political frames and a consequent willingness to collaborate with other political actors have resulted not only from governance-induced factors but also from changes related to the institutionalisation of movements. This extensive institutionalisation in the West has, on the one hand, facilitated movements' collaboration with other types of political formations while, on the other, it has provided legitimacy and resources to the social movement sector, altering its features in a relevant fashion. In several countries, the social movements of the 1970s and 1980s have undergone a process of institutionalisation exemplified by their inclusion in a variety of policy-making deliberative fora and their rising popularity in public opinion (Ruzza 2004). This has for instance resulted in the creation and successful entrenchment in the machinery of the state of movement parties, such as green parties or some ethnic parties which have strong roots in, and continuing ties with, the social movement sector (Dalton and Kuechler 1990: 189-90; Müller-Rommel 1990). But these parties are also connected to the mainstream political system and to processes that in several EU countries are progressively institutionalising parties in the machinery of the state.

Much of the action repertoire that used to characterise social movements in recent decades has been adopted by a variety of political organisations. It is not unusual to see coalitions of opposition parties, and sometimes even governing parties and their leaders, organise or take part in protest marches or public events that borrow much of the action repertoire previously only utilised by social movements. The end result is a much more fragmented and institutionalised social movement sector which, together with social movement groups still 
strongly oriented to disruptive forms of action, also includes a mix of organisations that express a wider action repertoire. Hence the same movements may use different tactics to address different components of the political system within a state, and also simultaneously focus on the public sphere, and on policy making at different levels of governance. In this context, social movements are increasingly merging with other components of civil society to provide representation, advocacy, services and public communication to their constituencies, which are often the weaker sectors of the population that the public sector should address: for instance, the poor, ethnic minorities and women. Thus social movements are already part of broad coalitions, and are likely in the future to become increasingly so; for instance, anti-racist coalitions which bring together sections of leftist parties, third sector organisations, but also public interest groups such as civil rights groups and also service delivery organisations such as development NGOs, religious organisations, migrants' associations and some professional organisations.

Coalition behaviour does not necessarily alter the main identity of movements. However, coalition behaviour is in itself an important source of policy change which should be studied in relation to developments in other types of political formations, such as public interest groups and third sector organisations. Before discussing coalitions as self-standing political formations, it is necessary to consider how each of the forms of contentious political participation is changing in relation to changes in the role, structure and power of the state.

\section{Citizens' groups}

At any point in time there is often a wide array of campaigns which are supported by various groups. These can be labelled as civil society advocacy or as civic collective action events. They are coordinated by public interest groups with different degrees of formalisation and territorial bases of differing extents. For instance, on examining public demands over a thirty-year period and distinguishing between these events and social movement protest events, Sampson et $a l$. (2005) have shown that in the Chicago area civic engagement is durable, and that as 'sixties-style' protest declines, so hybrid-repertoire events increase. Cooperation among citizen grassroots groups is frequent and is facilitated by action coordination via the internet, where information, practical manuals and exchanges with other groups are easily accessible. For instance, one can find online manuals that detail how to contact government officials in different contexts, and how to address the media and the public (Dobson 2003). Thus, while citizens' groups often interact with social movement organisations, they have different features. They are often relatively short-lived local-level campaigns which re-form on related issues through the advocacy of key individuals and establish broad local-level coalitions: this is the case, for instance, with many groups protesting against localised environmental threats; they may comprise broad sets of actors ranging from landowners to environmental protesters. These groups, just like social movement organisations, learn even more effectively 
how to approach the complex decision-making structure of multi-level governance. For instance, at the EU level they find support in obtaining funds, legal advice and policy impact for local-level campaigns. Such information is often available in support manuals and via decentralised umbrella organisations that connect with levels of government (ECAS 2002). Hence the environment of citizens' groups has been redefined in terms not dissimilar to those of social movements.

\section{Public interest groups}

Also important in civil society advocacy coalitions are policy-oriented public interest groups. These are sometimes inspired by social movements and recruit social movement activists. They can be defined as 'lobbies who seek the attainment of a collective good the achievement of which will not selectively benefit the membership or activists of the organization' (Imig and Berry 1996). Clearly, this definition is compatible with what many social movement organisations do, but also with organisations that are not generally engaged in protest actions, which do not claim a social movement identity, or which express an 'out of the system' character. Public interest groups can be differentiated from citizens' groups by the fact that they may be think-tanks of professionals approaching the policy-making environment and not necessarily reflecting a broader constituency. They are often related to grassroots organisations which they claim to represent, and they not infrequently express an ideological connection to social movements. This means that they consider themselves the 'legal arm' of movements' organisations to which members may subscribe.

Again, it appears that a rigid differentiation between social movements and interest groups on the basis of the activities performed is unfeasible. Their orientation is often practical. In the context of EU environmental policy, for instance, even groups whose members declare an environmentalist identity frame their action in terms of extending the boundaries of the policy change possible in the given context of an EU institution. As a consequence, they cannot be defined in terms of any 'out of the system' orientation. In this context, therefore, the ideological connection with the social movement sector is important. It differentiates social movements from public interest groups with no social movement of reference, such as the anti-poverty lobby or the consumer movement, which, despite its name, has little mobilisation potential.

The ideological reference points of a movement mean that lobbying activities, information-providing activities, participation in decision making and in agenda shaping take place with implicit potential recourse to the public sphere - in terms of either media campaigns or disruptive action. One may accordingly define a social movement-inspired coalition in organisational identity terms and consider public interest groups to be an integral part of such a coalition. A movementinspired coalition is then able to triangulate with other political formations which also claim allegiance with social movements from different institutional bases, certain third sector organisations for instance. 


\section{The service delivery sector}

As several observers have pointed out, the third sector has acquired prominence as an important component of the decision-making system of several European societies. This development corresponds to both the numerical growth of the third sector's organisations and affiliates, and to processes of institutionalisation that have seen its role redefined and increased. In many European member states there are now important areas of public policy that increasingly rely on the expertise, and contributions of resources and personnel, that the sector provides. However, the role of the third sector as an interface between the state and the public sector has come under scrutiny. Issues of transparency in the selection of associations, their accountability and effectiveness have been raised. Some of the reasons for the third sector's increased importance concern economic and political processes relating to the changing functions of hollowed-out states increasingly unable and unwilling to cope with contemporary welfare demands. But equally important are generalised changes in the political discourse, which from both left and right have reflected a more central role of the third sector. However, the role of the sector changes in different polities and is shaped by the ultimate control of regulatory and distributive resources available to political actors.

What political actors say about the role of the third sector is important because, as the sector becomes increasingly organised and institutionalised, the political system increasingly determines its modalities and margins of operation. Notably it determines the political architectures within which the third sector operates, the types and quantity of functions available to its organisations, tax regimes, normative frameworks for relationships with other social institutions such as churches and businesses, and incentives and disincentives in different areas of public policy. Of course, given the social relevance of the third sector, the internal views on it and perceptions of its role and functions are also highly consequential. Also important are the dominant expectations of the state and other social institutions, and inter-organisational relations within the sector. The concrete outcomes of the third sector in terms of quality and type of service delivery are then oriented both by dominant ideologies within the sector and by the political ideologies that frame its role in society.

In recent years, the third sector has received sustained attention from academics researching the impact of changing forms of service delivery. Participation in the sector has also been studied in terms of attitudinal implications regarded as essential for good institutional performance. Since Putnam posited a link between levels of associationism and institutional performance, close attention has been paid to the issue (Putnam et al. 1993). Analyses of the roots of social solidarity and its relations with third sector activities have been highly controversial, but generally accepted. This has attracted much attention from political actors and promoted public policies favourable to its expanded role.

The third sector has grown substantially throughout Europe, a factor which encourages its closer relationships with other sector-specific organisations - both 
political and service-oriented. Like the social movement sector, the third sector is in many contexts increasingly institutionalised within the state. In several countries the sector has acquired major political and also social and economic importance. Analysts have pointed to the specifically modernising function of the third sector in several member states, where it is replacing fading communal solidarity and offering new universalist social identities. This is typically the case in northern Europe, but it is also increasingly apparent throughout southern Europe, where the sector's importance has been enhanced by specific phenomena.

However, unlike in some northern European democracies, where the development of the welfare state partially eroded the importance of the third sector, in southern Europe the sector's role is still significant, given the late advent and modest extent of public welfare. But even the limited importance of the decommodified welfare state has decreased in the wake of neo-liberal policies and economic globalisation. This has occurred at a time of progressive erosion of the potential for political activism by the social movement sector, which, as mentioned, has become progressively institutionalised, less ideologically driven and more concrete, and has assumed some of the features of the voluntary sector, creating space for new synergies. Nonetheless, the social movement background of some of the new cadres has proved significant in several contexts. As the size, scope and composition of the sector grows, its contribution to delivering a range of public services becomes increasingly welcome to the population and political formations; and it is often essential, given the historical deficiencies of the public sector in several contexts, and the new challenges raised by economic globalisation. Over time, this has produced a voluntary sector which is highly institutionalised, particularly in relation to local authorities in several EU member states.

However, because a large flow of public money goes to the third sector, political discussion has ensued on how best to use it. The sector is thematically very diverse, it is internally formed by competing organisations, and it plays a variety of roles wider than mere support for specific constituencies. For these reasons, the potential channels and policy sectors for utilising public money in the sector are very broad, and therefore politically controversial. Political forces have reacted to this situation by reflecting on potential interactions between the state and the sector in their political communication. And the sector has reacted by increasing its proactive engagement in the policy environment, which has brought it into closer linkage with social movements. It is now possible to consider mixed representational and service delivery coalitions that unite different types of civil society groups.

\section{Civil society coalitions}

Coalitions can be mechanisms of collaboration among different types of political formations: for instance, the 'New Deal Coalition' included the Democratic Party, labour unions, religious groups and racial minority groups. The principal concern of these actors was a presidential election, but they had other policyshaping goals as well. Likewise, civil society coalitions can also be formed by a 
mix of rather different formations - for instance, political and civil society actors, and possibly business organisations involved in the social economy. Indeed, civil society coalitions are now the normal form of interaction between the public sector and organised non-state actors. Clearly, different types of coalitions will have different characteristics. As noted, social movement organisations may be part of coalitions, and when they are, the coalition has at its disposal the weapon of disruptive action and established mechanisms of structured relations with the media. Other coalitions may focus on interacting with the conventional political system and ensuring contracts for their servicedelivering activities. On the basis of broader concepts such as the civil society coalition, some general considerations are now possible. A great deal of work has been produced on the relations between associations and policy making in recent years. In different ways, much of this work also touches upon the various attitudinal, cultural and regulatory issues that qualify this relation.

The contiguity between the associational field and the political field is defined by ideological boundaries and, as has been argued, this contiguity is increasing with the transposition from government to governance because any sharp divide between the associational and the state sector is eroding for a number of reasons - particularly to the extent that associations come to represent local communities in international governance settings. Relations between associations and political formations are therefore increasingly ideologically driven, and the selection has significant consequences for democracy. For instance, at the municipal level, changes in the colour of the local government may result in a complex process whereby one coalition replaces another in the full range of service delivery and advocacy functions (Ruzza 2008b).

\section{Discussion: a contextual view of civil society and the public sector}

It emerges from the foregoing analysis of the distinguishing traits of civil society organisations that their functions, action repertoires and identities are often closely interlinked. In the public sector, organised civil society performs functions of advocacy, policy pressure, information provision, minority representation, monitoring of policy-making and implementation, and political-societal interaction on issues of political communication. From this perspective, classical analyses of the concept of representation in governance structures need to be reconsidered in light of a more articulated interaction between state and nonstate political actors and a more articulated role of associations (Pitkin 1967; Warren 2001). Thus, civil society activities can broaden and redefine the political space and act on behalf of specific social constituencies. Associations contribute to the welfare of these constituencies by engaging in a variety of interactions with the public sector.

They may choose to engage in these interactions either while seeking autonomy from the state and its territorial articulations or by seeking involvement. Different civil society formations assess the advantages and disadvantages of 
institutionalisation in different ways. Organisations closer to the uninstitutionalised social movement sector may reject involvement with the public sector, or accept only some forms of involvement. For instance, the environmentalist organisation Greenpeace refuses to receive EU funds, but still engages in advocacy processes at EU level and collaborates with other environmentalist organisations which receive the majority of their funds from the European Commission. Some organisations have described participation activities as 'a tyranny' which, in exchange for resources and influence, engenders compliance and limits the possibility of criticism. Clearly, different types of civil society organisations will exhibit different institutionalisation trajectories, different types of inclusion, and a different mix of functions in institutional, non-institutional and public sphere settings - the empirical dimensions of this mix of roles would be an important subject for further research. In any event, their task is increasingly facilitated by a very positive emphasis on civil society; and a set of consultation practices between policy makers and civil society actors has emerged on a global scale, constituting a new paradigm in policy formation and service delivery at all levels of governance.

This new paradigm has, however, acquired particular salience at EU level because of the greater needs for political legitimacy that institutionalised civil society can provide to a set of supranational institutions. Their remoteness from specific constituencies makes the role of civil society as provider of alternative chains of representation particularly useful, in terms of both top-down and bottom-up dynamics. Second, we pointed out that the institutionalisation dynamics that civil society formations have generally undergone are more pronounced at the EU level. Among the reasons previously identified, we emphasised the selective dynamics of inclusion in policy-making activities, and the selective barriers to access to EU institutions that filter out uninstitutionalised formations more rigorously than in member states. We have also emphasised the greater necessity of external inputs at EU level and the related reliance on deliberative and consensual policy making given the limited size of the European Commission, its limited ability to reach and implement authoritative decisions, and representational and informational limitations.

\section{Conclusions}

With specific reference to the EU level, but also drawing broader theoretical implications, this chapter examined the implications of the concept of political representation when applied to the advocacy activities of non-state actors. It is argued that the interaction between civil society and EU institutions, and more generally the public sector, is becoming stronger and more useful because of three main factors, which acquire particular relevance at EU level. First, the public sector is increasingly turning to civil society because of a need to redress the overarching influence of business pressure groups. This extends more generally to a disenchantment with some aspects of New Public Management and its ethos (Dunleavy et al. 2006). At EU level, this is a particularly salient factor as 
the resource-based political-capital filters that selectively empower the representation of private groups over public interest groups are particularly strong. Second, the public sector is in need of additional resources, particularly information, the ability to represent specific social groups, and donations of activists' time and energy that only civil society can offer. Again, the process of EU representation, which emphasises governments over parliaments and unequally represents populations, makes the role of civil society representation particularly important. Third, resource needs are redefined by changes in the structure and functions of civil society organisations and their modes of operation. In this context, we demonstrated the integration of purposes, modes of representation and general attributes of efficacy transparency and democracy that different types of civil society formations can achieve if they work together as part of an associational ecology of organisations. While these dynamics are applicable to the entire European public sector, we have argued that they have special salience at the EU level.

\section{References}

Bonnett, A. (1993) Radicalism, Anti-Racism and Representation, London: Routledge.

Cini, M. (1996) The European Commission, Manchester: Manchester University Press.

Dalton, R. J. and M. Kuechler (eds) (1990) Challenging the Political Order, Oxford: Oxford University Press.

Dobson, C. (2003) The Troublemaker's Teaparty: A Manual for Effective Citizen Action, Vancouver: New Society Publishers.

Dunleavy, P., H. Margetts, S. Bastow and J. Tinkler (2006) 'New Public Management Is Dead: Long Live Digital Era Governance', Journal of Public Administration Research and Theory 16(3): 467-94.

ECAS (2002) A Guide to European Union Funding for NGOs, Brussels: ECAS.

European Commission (1993) 'An Open and Structured Dialogue between the Commission and Special Interest Groups', Official Journal of the European Union, C Series, 63(2) (5 March): 2-7.

European Commission (1995) Communication from the Commission on Promoting the Role of Voluntary Organisations and Foundations In Europe, Brussels: DG Enterprise.

European Commission (2000) 'The Commission and Non-Governmental Organisations: Building a Stronger Partnership' COM (2000) 11 final, 18 January 2000, pp. 1-26.

European Commission (2006) 'White Paper on European Communication Policy', COM (2006) 35 final.

Greenwood, J. and M. Aspinwall (eds) (1998) Collective Action in the European Union, London: Routledge.

Hooghe, L. and C. Robert Schuman (1998) Images of Europe: Orientations to European Integration among Senior Commission Officials, San Domenico: European University Institute.

Imig, D. R. and J. M. Berry (1996) 'Patrons and Entrepreneurs: A Response to "Public Interest Group Entrepreneurship and Theories of Groups Mobilization", Political Research Quarterly 49(1): 147-54.

Jachtenfuchs, M. (1996) International Policy-Making as a Learning Process? The European Union and the Greenhouse Effect, Aldershot: Avebury. 
Judge, D. (1992) 'Predestined to Save the Earth: the Environmental Committee of the European Parliament', Environmental Politics 1(4): 186-212.

Keck, M. E. and K. Sikkink (1998) Activism Beyond Borders, Ithaca, NY: Cornell University Press.

Marks, G. and D. McAdam (1996) 'Social Movements and the Changing Structure of Political Opportunity in the European Union', in G. Marks, F. W. Scharpf, P. C. Schmitter and W. Streeck (eds), Governance in the European Union, London: Sage, pp. 95-120.

Mazey, S. and J. Richardson (1994) 'Interest Groups in the European Community', in S. Mazey and J. Richardson (eds), Pressure Groups, Oxford: Oxford University Press, pp. 191-213.

McAdam, D. and D. Rucht (1993) 'The Cross-National Diffusion of Movement Ideas', Annals of the American Academy of Political and Social Science 528: 56-74.

Michelmann, H. J. (1978) Organizational Effectiveness in a Multinational Bureaucracy, Farnborough: Saxon House.

Müller-Rommel, F. (1990) "New Political Movements and "New Politics" Parties in Western Europe', in R. J. Dalton and M. Kuechler (eds), Challenging the Political Order: New Social and Political Movements in Western Democracies, Oxford: Polity Press, pp. 209-31.

Pitkin, H. (1967) The Concept of Representation, Berkeley: California University Press.

Plotke, D. (1997) 'Representation is Democracy', Constellations 4(1): 19-34.

Putnam, R., R. Leonardi and R. Y. Nanetti (1993) Making Democracy Work, Princeton, NJ: Princeton University Press.

Ranci, C. (2006) Il volontariato, Bologna: Il Mulino.

Rehfeld, A. (2005) The Concept of Constituency: Political Representation, Democratic Legitimacy and Institutional Design, Cambridge: Cambridge University Press.

Rootes, C. (2007) Environmental Protest in Western Europe, Oxford: Oxford University Press.

Rootes, C. (2008) Acting Locally: Local Environmental Mobilizations and Campaigns, London: Routledge.

Rosenbaum, A. (2006) 'Cooperative Service Delivery: The Dynamics of Public SectorPrivate Sector-Civil Society Collaboration', International Review of Administrative Sciences 72(1): 43-56.

Ruzza, C. (2004) Europe and Civil Society: Movement Coalitions and European Governance, Manchester: Manchester University Press.

Ruzza, C. (2006) 'European Institutions and the Policy Discourse of Organised Civil Society', in S. Smismans (ed.), Civil Society and Legitimate European Governance, London: Edward Elgar, pp. 169-95.

Ruzza, C. (2008a) 'EU-Society Relations and Interests Intermediation: A Contribution to the Debate', in B. Kohler-Kock and F. Larat (eds), Efficient and Democratic Governance in the European Union, Mannheim: Mannheim University Press, pp. 303-24.

Ruzza, C. (2008b) 'The Italian Antiracist Movement Between Advocacy, Service Delivery, and Political Protest', International Journal of Sociology 38(2): 55-64.

Sampson, R. J., D. McAdam, H. McIndoe and S. Weffer-Elizondo (2005) 'Civil Society Reconsidered: The Durable Nature and Community Structure of Collective Civic Action', American Journal of Sociology 111(3): 673-714.

Schmitter, P. (2000) How to Democratize the European Union and Why Bother?, Oxford: Rowman \& Littlefield.

Seligman, A. (1992) Civil Society, New York: Free Press. 
Skocpol, T. (2003) Diminished Democracy: From Membership to Management in American Civic Life, Norman: University of Oklahoma Press.

Smismans, S. (2004) Law, Legitimacy, and EU Governance: Functional Participation in Occupational Health and Safety Policy, Oxford: Oxford University Press.

Stevens, A. (2009) 'Representative Bureaucracy - What, Why, and How? Evidence from the European Commission', Public Policy and Administration 24(2): 119-39.

Tilly, C. (1978) From Mobililization to Revolution, Reading, Mass.: Addison-Wesley.

Tilly, C. (1984) Big Structures, Large Processes, Huge Comparisons, New York: Russell Sage Foundation.

Urbinati, N. (2000) 'Representation as Advocacy: A Study of Democratic Deliberation', Political Theory 28: 758-82.

Urbinati, N. and M. E. Warren (2008) 'The Concept of Representation in Contemporary Democratic Theory', Annual Review of Political Science 11(1): 387-412.

Walker, J. L. (1991) Mobilizing Interest Groups in America: Patrons, Professions and Social Movements, Ann Arbor: University of Michigan Press.

Warren, M. (2001) Democracy and Association, Princeton, NJ, and Oxford: Princeton University Press.

Warren, M. and D. Castiglione (2004) 'The Transformation of Democratic Representation', Democracy and Society 2(1): 5, 20-2.

Weiss, L. (1998) The Myth of the Powerless State, London: Polity Press.

Woodward, A. E. (2008) 'Too Late for Gender Mainstreaming? Taking Stock in Brussels', European Social Policy 18(3): 289-302.

Young, A. (1997) 'Consumption Without Representation? Consumers in the Single Market', in H. Wallace and A. R. Young (eds), Participation and Policy-Making in the European Union, New York and Oxford: Clarendon Press and Oxford University Press, pp. 206-34. 



\section{Part II}

\section{The European Union}





\title{
4 Europeanization of non-state actors
}

\author{
Towards a framework for analysis
}

\author{
Karolina Borońska-Hryniewiecka
}

\section{Introduction}

After a long period of academic interest in the origins and nature of European integration there has been a shift in focus away from the ontological questions of whether the EU is supranational or intergovernmental, and towards more postdefinitional issues connected with how it affects the agency and structure of different actors; in other words, how Europeanization matters. Like many scholars who deal with the general aspects of political institutions, researchers of Europeanization are usually less concerned with whether European institutions matter, than to what extent, in what respects, through what processes, under what conditions, and why institutions make a difference (Weaver and Rockman 1993). The subject of their interest is to study how Europe, or the system of European governance, affects other actors: states and national institutions (Olsen 2002; Börzel 2002); sub-national entities, such as regions and territorial politics (Malloy 1997; Keating 2004a, 2004b; Dobre 2005); representation structures, such as political parties and movements (Ladrech 2001; Roller 2004); interest groups (Sroka 2004; Eising 2008); and different segments of civil society (Warleigh 2001; Ruzza 2004, 2006). This chapter focuses on non-state actors (hereafter NSAs) and their responses to Europeanization.

The involvement of NSAs in European and global politics can hardly be characterized as novel, but intensifying economic and social exchange and the emergence of new modes of governance have given them much greater visibility and made them the subject of deeper comparative studies. The reason for this is the fact that the impact of the EU and its institutional system has caused significant changes to non-governmental interest representation. New vectors of power and forms of participation have arisen in this sphere, which influences the image of the European public space. ${ }^{1}$ The Europeanization of NSAs requires special attention because it concerns civil society's participation in European governance. It is one of the weakest points of the EU today and is at the heart of the challenge to overcome the European democratic deficit.

The multiple NSA activities within the EU are reflected both in the variety of interests represented by the different NSAs and in the multiplicity of organizational beings working in the name of promoting vital interests and undertaking 
strategies aimed at their realization. This diversity, on the one hand, creates possibilities for a wide interpretation of the phenomenon of Europeanization of NSAs; on the other, however, it causes problems for making generalizations about the different modes of adaptation to Europe by particular actors. Yet such ambiguity may still yield interesting results.

This chapter does not intend to give an exhaustive account of research on the development of European civil society ${ }^{2}$ or interest intermediation at different levels of the EU, but seeks to highlight the different ways of conceptualizing the phenomenon of Europeanization of NSAs that could be used in comparative studies on Europeanization. By reviewing the contribution of neo-institutionalism and policy networks analysis within European studies, this chapter distinguishes between the different actor-oriented approaches that explore the impact of and adaptation to the process of Europeanization. The first approach, based on rational choice theory, takes as its central notion the problem of resource dependency of interest groups and their strategies. The second approach focuses on the sociological aspects of institutional adaptation, stressing the importance of collectively shared values, understandings and logic of behaviour. The third one stresses the importance of history and its inefficiencies in analysing institutional change. Are NSAs mainly the objects or agents of Europeanization? Can they fulfil the two functions simultaneously? A number of examples will illustrate the different arguments.

\section{NSAs on the European scene: definitional problems}

NSAs are the principal structures of organized society beyond governments and public administration. For the purposes of this chapter, they may be defined as a wide range of non-governmental agents whose participation in the political, economic and social life of the European Union, as well as in the global sphere, is formally recognized. NSAs include different kinds of interest groups: non-governmental organizations (NGOs); social movements; advocacy and promotional groups in all their diversity; functional interest groups ${ }^{3}$ as social partners (such as trade unions and employers' organizations); and sectoral organizations (such as enterpreneurs and consumers' associations). NSAs may also include universities, research institutes and epistemic communities organized to promote and achieve certain educational goals. In practice, it means that participation is open to all kinds of community-based actors whose interests, objectives, strategies, ideology, level of organization, support base, legitimacy and degree of international recognition vary greatly. ${ }^{4}$ This chapter will use the terms NSAs and interest groups interchangeably, since they share the same basic characteristics, yet their structure and agency vary depending on their character and status.

The involvement of NSAs in European policy making has increased gradually over the last 30 years: notably in the establishment of the European Social and Economic Committee in 1957; and in the signing of the Single European Act of 1987, which created the single market within the EU, and introduced the consul- 
tation procedure and extended qualified majority voting to new areas. These steps resulted in many NGOs actively participating in the creation of common European standards and led different interest groups to lobby at the European level rather than in their national 'playgrounds'. The Leaken Conference of 2001 established a qualitative milestone for the recognition of the participation of NGOs in European governance and included for the first time the representation of NSAs in the Convention working on the Constitutional Treaty. The most recent, yet still not institutionalized, development in the Europeanization of NSAs is the Lisbon Treaty - with its Charter of Fundamental Rights, which further enhances the European Social Dialogue and institutionalizes citizens' initiatives. All of these stages constitute a continuous process of Europeanization of NSAs. But what exactly is Europeanization?

\section{Making sense of Europeanization}

Europeanization is sometimes interpreted as a globalization process in the European realm (Matei 2004). Indeed, as in globalization, one aspect of Europeanization is the transformation of national or regional phenomena into supranational (European) ones through a combination of economic, sociocultural and political forces. Europeanization is a contiguous but secondary process to European integration. The integration of Europe has become the grammar in use for national governments, NSAs and societies. The range of understandings of Europeanization varies from: 'transnational process of dissemination of the European norms and practices' (Matei and Matei 2007), through 'institutional adjustment to the EU' (Börzel 2004), to 'a specific strategy of solving conflicts around the world' (Featherstone 2003). In spite of existing conceptual contestation, the majority of researchers speak of Europeanization when some part of the domestic political system is affected by something European (Vink 2002). This definition could be rendered more precise as the 'institutional change in which domestic policy areas become increasingly subject to European policy-making' (Börzel 1999: 574). This chapter will use the broad definition of Europeanization proposed by Claudio Radaelli. ${ }^{5}$ For him, it is a process consisting of different sub-processes: construction; diffusion; and the institutionalization of formal and informal procedures, rules and ways of doing things, shared beliefs and norms, which are first defined and consolidated in the EU policy process and then incorporated into the logic of domestic discourses, identities, political structures and public policies (Radaelli 2003: 30). However encompassing it may seem, such a way of looking at Europeanization leaves space for a broader interpretation of the different adaptational patterns of NSAs and their modes of interest representation. Moreover, it underlines the importance of 'change', not only as the changing agency of political actors and policy outputs, but also in terms of the underlying structures of meanings and identities. Since this chapter aims to draw an analytical framework of the impact of Europeanization upon the public sphere and the relations between the EU administration and NSAs, Europeanization will be treated here as: a process (of diffusion, learning, adjusting, and the reorientation 
of politics); effect (of engagement with Europe); cause (of further integration); and relation (between the EU and other actors). Before moving on to analyse NSA responses to the EU, it is useful to examine an important general approach to Europeanization.

One of the earliest conceptualizations of Europeanization, by Ladrech, defines Europeanization as 'an incremental process of re-orienting the direction and shape of politics to the extent that EC political and economic dynamics become part of the organizational logic of national politics and policy making' (1994: 69). This emphasizes the 'top-down approach' to Europeanization where 'change' emanates from the impact of the EU on national policy and relies on an analysis of the implementation of the European policies. It might be represented by the following schema:

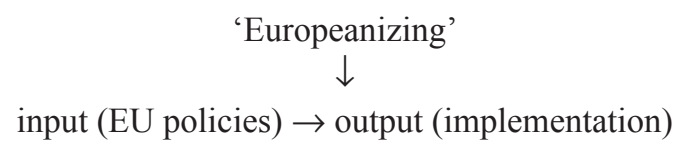

Approaching the Europeanization of NSAs exclusively from this top-down perspective may fail to recognize the complexity and two-directional character of this process (Risse et al. 2001: 1). It is important to acknowledge that domestic actors are never just passive recipients and implementers of European norms; after all, European policies do not 'come out of the blue', but are the result of political action, lobbying and negotiations by the same domestic actors who shift domestic issues and delegate their will to the European level (Putnam 1988). This is where the 'bottom-up' approach becomes helpful. The 'bottom-up' approach, which will be applied in this chapter, has a different research design and focuses on domestic actors, their resources, preferences, values and relations, checking how and to what extent they respond and adapt to the challenges of Europeanization. Here, Europeanization occurs when domestic actors begin to affect the policy of the EU in a given area. The following scheme explains it:

domestic actors and interactions $\rightarrow$ intervening variables (EU and other pressures) change at the actors level $\leftarrow$ change at the European level $\lrcorner$

The bottom-up process is seen as the emergence of new institutions, practices, frameworks and symbols at the domestic level in response to the EU. These are then transferred, in the form of a particular strategy or action, onto the European level and become a common operational logic in the EU system of governance. Europeanization is a dependent variable, an explanandum and a problem to be studied. Moreover, it covers both the vertical and horizontal dynamics of the relations between the EU and NSAs, whose patterns of behaviour are shaped by both newly generated European values and knowledge and their domestic logics. 


\section{How does Europeanization affect NSA? Neo-institutionalism revisited}

According to institutional theory, every institutional change has a broader qualitative dimension and presumes an evolution of the character of the relations between different political and social actors. ${ }^{6}$ The impact of Europe may vary depending on many factors connected with the nature of NSAs and the contexts in which they are rooted, but it requires at a minimum that NSAs redefine themselves in a broader perspective within a framework of multi-layered interests. The majority of existing NSAs were created in particular member states and possess certain national peculiarities reflected in their agency and structure. Many of them are used to operating within their domestic realm, following wellknown patterns of interest intermediation, responding to only a few stakeholders and anticipated policy outcomes. Europeanization made the EU a new decisive factor in the pursuit of policies traditionally considered domestic, such as employment, immigration or asylum. Now, as NSAs have entered the EU supranational networks of cooperation, they have had to learn how to collaborate, exchange resources and use each other's experiences. Networking and cooperation among Eurogroups are essential, since they have to respond to the same EU institutions and overcome common problems connected with by-passing certain gatekeepers who often block access to European decision making. Europeanization has affected many areas of NSA activity: organizational structure; patterns of behaviour; lobbying strategies; and relations between NSAs and member states.

Operating at the European level has generated changes that were the result of both formal requirements and processes of learning and rational calculation. The institutional interaction of policy actors at the various levels of the European governance system has led to the redefinition of national and regional identities within the European context, where the exchange of resources takes place within differentiated and interconnected networks. Explanations for varying degrees of influence and power of different interest groups were attributed to their ability to generate and operationalize these resources. The multi-level structure of NSAs' participation in the EU requires multi-level agency and generates multi-level responses to their actions. Therefore to build a constructive and reliable framework of analysis it is indispensable to take a broad and multi-level approach, which will identify the changes in the micro-institutional structures of NSAs, linking the domains of policy, politics and polity at the different levels of the EU. Because EU-NSA relations are shaped by both institutional structures and their impacts, as well as by normative aspects and preferences, a neo-institutional perspective might offer a useful means of analysing the Europeanization phenomenon. Indeed, much of the Europeanization literature is institutionalist by nature and there is a broad agreement that an awareness of the new institutionalism is indispensable for understanding how Europeanization is conceptualized (Bulmer 2007; Börzel 2002, 2005; Featherstone and Radaelli 2003). Neoinstitutionalism comes in many flavours that might serve as complementary 
ways of analysing and understanding the institutional changes connected with Europeanization. For any researcher dealing with NSAs, it is useful to distinguish between the three main theoretical ways of conceptualizing the adaptational processes in response to Europeanization. ${ }^{7}$

\section{Resource dependency in Europeanization study}

The Resource-Dependency Approach (RDA) to Europeanization originates from rational choice institutionalism, which assumes that any change in the institutional structure means a redistribution of resources among political actors. ${ }^{8}$ As Ramon $\mathrm{i}$ Sumoy notes: 'Regardless of the origin of the change (exogenous or endogenous), it empowers some actors over others' (2005: 119). In the case of Europeanization, the institutional change is European integration, which causes a redistribution of power resources at the domestic level resulting from EU membership. RDA assumes that actors are rational, purposeful and goal-oriented. They have a fixed set of preferences and act quite instrumentally, striving to maximize profits by deploying the resources at their disposal. Because any individual or collective is dependent on others to achieve its goals, actors tend to exchange resources among themselves. This exchange is based on a set of power relations consisting of a joint assessment of strategies and interests. Radaelli notes that it is better for actors to reformulate their expectations before the process of bargaining is concluded, in order to gain some credit at home, or to limit the negative consequences of future decisions (Radaelli 2004: 12). So why have some NSAs, such as environmental NGOs and trade unions, been able to penetrate EU institutions while others have not? The answer might lie in an analysis of the resources of NSAs. The survival, expansion and effectiveness of a particular group depends on the control of resources. In policy networks literature the control of these resources is seen to lie in the hands of the organizational elite (Sroka 2001: 39). ${ }^{9}$

\section{Access to political decisions}

Access to EU decision making prejudges the success of the Europeanization of NSAs. Some NSAs are regarded as legitimate interlocutors, so-called 'insider groups' (such as trade unions in the social dialogue), while others are blocked from the negotiating table. In the EU, certain gatekeepers (notably member states, but also lobbyists or well-established NGOs) can facilitate or block contact with decision makers. Moreover, attempts to build high firewalls around policies in a given sector, so that they cannot be altered, are not rare (Peterson 2003). With regard to NSA participation in EU governance, Schmitter introduces the notion of 'holders': organizations that possess some quality or resource that entitles them to participate in the decision-making process (2002: 62). There must then be a demand for them on the part of other stakeholders who have the power of letting NSAs into that process.

The European Commission (EC) plays a significant role in the process of including NSAs into European decision-making. In an ideal scenario, NSAs 
undergo a twofold process of Europeanization: they put knowledge into the European legislative process, and they influence implementation processes and the democratic legitimacy of the EU. However, some NSAs are more powerful than others and many representatives of civil society are still excluded from European governance. For example, the ability of NGOs to influence EU policy output is generally less than that of corporate lobbyists. Warleigh stresses that NGOs are still too weak to play a significant role in Union policy, because they lack more regular access to EU decision makers (2001: 623). This factor is connected to a second: lobbying strategies.

\section{Knowledge and expertise}

With its own system of law and the capacity to impose its will on a polity of over 470 million citizens, the EU may seem very powerful, yet in fact it is comparatively weak in terms of resources. Since the EU's policy is highly technical, it relies heavily on informational assets and expertise. These resources can become an exclusionary device, especially for NSAs, at the supranational level, because representative institutions are very often inefficient at providing specialist knowledge. The EC, as initiator of legislation and policies, benefits from the expertise of thousands of expert groups, lobbyists and interest groups. Certain policy fields such as environment, agriculture and nuclear or waste policy require a broad, Europeanized approach, taking into account all possible repercussions of the proposed solutions for the different stakeholders. Although member states still control access to political decisions at the European Council level, NSA experts who share specialized knowledge in particular policy fields are of great value for Commission projects. These NSA experts tend to identify and 'bond' with each other in order to shift the European policy agenda in the direction of a policy change, which quite often goes against the interests of the member states. This happened during the EU Energy Summit and the European Climate Pact, where environmental NGOs lobbied for a decrease in emissions of greenhouse gases. Not only did they demonstrate, they also contributed to effective problem solving in the form of professional information and expertise. On the other hand, NSAs may seek to influence the European agenda by politicizing certain issues and making broader European agreements. Alliances within epistemic communities of researchers created within the EU Framework Programme (FP) for funding collaborative research illustrate this case. The main objective of the FP is to develop and strengthen the European knowledge-based society. Among the strategies of the FP are the 'networks of excellence', consisting of specialists from different disciplines collaborating on different scientific projects. FPs have expanded to become one of the largest items of expenditure in the Community's budget ${ }^{10}$ not least because much decision making about precisely who gets what from the programme has been delegated to communities of researchers and scientists. In this case the EU sponsors Europeanization initiatives in the process of knowledge and expertise exchange. 


\section{Mobilization and symbolic resources}

Unlike epistemic communities, politicized environmental or social development NGOs are highly dependent on their ability to mobilize their bases and to influence policy debates over issues such as auto emissions, euthanasia or social exclusion. Their activities can often be viewed as battles between competing interests, such as those NGOs advocating environmental protection against the industrial interests of the member states. Therefore, their strategies, being either confrontational (demonstrations, blockades) or moderate lobbying, require a high degree of mobilization of their elites and members. The degree and forms of social mobilization in the public discourse and collective action concerning European issues depend principally on the type of group identity. Dunleavy's distinction between exogenous and endogenous groups is instructive here (1991: 60-70). Exogenous groups possess predetermined identity sets such as origins, societal cleavages or professions, while the identity of endogenous groups is determined in a goal-oriented and rational way, mostly formed by the particular issues at stake (such as protecting the environment or supporting euthanasia). This distinction helps to illustrate the differences in collective action and the capacity to adapt in particular institutional and political contexts, in this case the EU. The first type of group, whose identity is based on belonging, acts according to strong normative and emotional factors, while the second type is determined by more rational and goal-oriented premises resulting from participation (such as the Basque nationalist movement against Greenpeace). Without going deeper into a sociological analysis of the different types of collective identities (see Bello's chapter in this volume), it is important to note that in spite of existing differences the two types of identities are not exclusive and should be treated as a theoretical model with possible variations in a particular situational context. Sometimes the strong sense of belonging to a particular interest group can facilitate the process of Europeanization, as can be seen in the Catalan and Basque nationalist parties' pro-European strategies, designed to circumvent the central government in the policy fields connected with the EU (Roller 2004).

Thus, mobilization is crucial in the Europeanization process as a bridge between belonging and active participation. The latter requires voluntary action and an understanding of the functioning of the EU and comes from the socialization process, which occurs through formal education, experience and participation in European affairs. In this case, NSAs are seen both as subjects and agents of Europeanization. As Warleigh points out, NGOs must not only increase their supporters' awareness of problems to be addressed at the EU level, but also provide mechanisms by which they can do so (2001: 236). This cognitive impact, however, presupposes the mobilization of interest in the EU by citizens. This in turn might occur through the politicization of EU issues - 'bringing the EU closer to the people'. It is unfortunately a difficult process due to the persisting complexity of EU governance structures. The result is a lack of social trust in European institutions. 
Moreover, the mobilization factor is closely connected with the symbolic resources of an interest group, which comprise both its external image and public relations, as well as its organizational culture and internal perception by its members and supporters. The symbolic resources are closely connected with group identity; they can help to reproduce a group's bonds and generate trust between members and those elites who play a crucial role in the process of the Europeanization of NSAs. ${ }^{11}$

\section{Affiliation and coalition potential}

Europeanization influences the mobilization potential of NSAs by letting them enter into EU-supported networks of collective action and supranational platforms of cooperation. This often results in a reorientation of their mobilization strategies towards norms and patterns of behaviour classified as 'European'. The coalition and affiliation potential is therefore an important resource in the European dynamic where dominant actors vary significantly between policy sectors. Europeanization through coalition building can be a successful way of pursuing particular interests which otherwise would remain unpoliticized and would not be addressed. According to rational choice theory, in interest-driven coalitions calculating and goal-oriented actors exchange resources while trying to remain as independent of others as possible (Börzel 2002: 19). Yet, in the EU independence is a scarce good. Very often it is not possible to gain access to a decisionmaking body without previous involvement in a so-called 'network of friends', which may house those gatekeepers mentioned above. Therefore, it is difficult for NSAs to generate trust as they interact in a turbulent environment of competing interests. One consequence is that EU policy networks of NSAs tend to be discrete, distinct and largely disconnected from one another, even when they preside over policies that are clearly connected, such as agriculture and environmental protection. Most have diverse memberships, extending from public to private, from European to global and sub-national, and lack clear hierarchies and visible leaderships. Coalitions are often ad hoc issue networks (Rhodes 1997; Peterson 1995), and therefore they are not durable or elastic. However differently rooted, interests become Europeanized in policentric networks when a common understanding of aims and strategies is developed. Therefore the agency of NSAs in the process of Europeanization depends on voluntary and interest-oriented coalitions, whose members accept a common frame of reference and rules set by the EU. In advocacy coalitions various undertakings are successful when common interests are supplemented by common values.

NSAs also form affiliations with EU institutions, especially the European Commission and the European Economic and Social Committee, in order to seek solutions to European problems. These affiliations are based on information exchange, expertise and policy projects. Sroka notices that in cooperation between NSAs and public administration there is a readiness of interest groups to take responsibility for any unsuccessful political and administrative decisions in which they were involved. Thus, interest groups are not simply rational actors 
maximizing their gains, but they are also stabilizing agents who take part in redefining and restructuring political space (Sroka 2004: 16). Charles Lindblom calls this 'the intelligence of democracy', which reconciles the political system's effectiveness and citizen participation (Lindblom and Woodhouse 1993).

\section{Europeanizing through socialization}

There is a clear contrast between rationalist (resource-dependent) and sociological strands in debates on Europeanization. Sociological institutionalism does not deny that actors are rational and goal-oriented, but it does state that actions are not entirely guided by strategic and calculating behaviour. Rather, actions depend on collectively shared values and understandings, rules of appropriateness and social expectations. 'Doing the right thing' is the guiding notion of institutional change. Institutions are seen not only as formal and informal rules and procedures, but also as systems of symbols and moral templates - reflecting a general understanding of collective human action, not of individual purpose. Institutional change is therefore conceived as a process of institutional adaptation through which new rules, norms and practices are internalized and substituted for old ones (Olsen 1997).

The success or failure of the European socialization process depends heavily on group identity, its mobilization and symbolic resources, as mentioned above. Warleigh stresses the important role of NSA elites in 'transmitting Europe' to their grassroots. This process is not only about increasing awareness of 'what the EU is all about', but also about operationalizing this capital - making people use their knowledge, EU funds, programmes, job opportunities, and so on. This is what Radaelli calls the European 'grammar in use', 'the ways of doing things' that change the logic of interaction, where NSAs take the role of agents of Europeanization. As Warleigh points out:

to facilitate the Europeanization of civil society, the EU requires a set of actors from outside the official circles to demonstrate the value of engaging with EU decision-making processes, to train citizens with relevant skills ... and to continue the process of generating transnational solidarity through the construction of cross-border supporter bases.

(2001: 621; see also Itçaina in this volume)

Moreover, since every institutional change creates a situation of insecurity, one of the most important factors for the reproduction and consolidation of European democracy lies in the social cognitive capacity of learning and internalizing new norms, as well as generating social trust. In Europeanized networks, where negotiations are needed to formulate agreements and compromises, this capacity enables an organization to learn new techniques of resource circulation. Longlasting bargaining of meanings, which is itself a form of socialization, leads to an increase in common trust and the institutionalization of consensus. The resulting agreement, which is often achieved in the form of compliance, becomes a proof of Europeanization, a value in itself, and is not a subject of exchange. 
Both rational and sociological approaches include the notion of learning in their analyses, but each understands it in a different way. Rational choice refers to so-called 'thin learning', whereby actors adjust their strategies to enable them to achieve goals in a new context, using a menu of well-known responses. Sociological institutionalism points to 'thick learning', involving changes in an actor's behaviour and the reshaping of their preferences and goals according to social pressures and the logic of appropriateness. An example of NSA involvement in the process of European learning is the Open Method of Coordination (OMC) on Social Inclusion, which slowly began to include NGOs in its schemes and to become a catalyst for NSA mobilization at the European level (see the Swedish example in Jacobsson and Johansson 2007). The OMC might in fact serve to facilitate the Europeanization of NSAs, which, participating in the transnational transfer of European knowledge and good practice, become empowered through the opportunity for infusing debates with their knowledge and ideas, and are able to foster new alliances and networks. Keck and Sikkink (1998) also note a positive phenomenon called 'the boomerang effect' of NSAs, which after entering into transnational networks bring their newly acquired knowledge back into the national context. Another example of European socialization for creating a common code of conduct in the NGO sector at the European level is the European NGO Confederation for Relief and Development (CONCORD). ${ }^{12}$

\section{Bridging the gap between calculation and 'appropriateness'}

There is wide-ranging consensus that EU institutions do not simply offer structural opportunities for interest groups (Marks and McAdam 19956; della Porta 2007; Eising 2008). They also shape the arenas of interest mediation in manifold ways. They set 'the rules of the game' that facilitate the process of resource exchange, as well as standards for appropriate interest group behaviour (European Commission 2001, 2002). The EU sets regulations and passes laws which member states and NSAs must implement and comply with. Yet these regulations affect to a great extent the functioning of interest groups, enabling and constraining them within the European logic of appropriate action (March and Olsen 1989, 2005). Ideally, rules are followed because they are seen as natural, justified and legitimate. However, looking at the political and socio-economic cleavages as well as different patterns of contestation and interest mediation in European states, we can expect national realpolitik and particular interests often to prevail over correct and generally accepted rules of conduct. Moreover, although the EU provides institutional and normative bonds that tie citizens together (for example, the common market, currency and citizenship; participation in European Parliament elections; European rules and standards; supranational partnerships in developing public policies), the cognitive and intellectual development of 'European society' does not occur simultaneously. The explanation might lie in Kenneth Galbraith's 'cultural gap' between society's 'conventional wisdom' and the independent 'march of events' (Galbraith 1998). Galbraith noticed that the distance between ideas and ways of assimilating them, between perceptual progress and changes in people's 
thinking, are not synchronized with the progress of events. They both acquire their own dynamics and only the 'struggle of ideas' leads to a change in the 'conventional wisdom'. In the European realm institutions and formal rules can be created instantly, but the process of internalization and institutionalization of norms requires a long and conscious effort on the part of society and its elites. In spite of the new institutionalism's claims that institutions reflect actor preferences (March and Olsen 1995), there are doubts in this field concerning the European democratic deficit and the role of NSAs in further integration. The goals and interests of social groups have a historical character, changing with the stream of events and interest constellations. Changed motives and preferences are followed by the creation of new systems of values and conduct. The thesis drawn from here might be that 'European civil society' is not developing in parallel with the institutions of the EU, as has been illustrated by the initial rejection of the European constitution and the Lisbon Treaty.

Arguments about this state of affairs are numerous and stem from ontological questions about the nature of the EU. Liberal intergovernmentalists view the integration process as the outcome of bargaining among member states where interest groups do not have much say in major policy decisions but rely entirely on their national governments to act as gatekeepers in the pursuit of their EUrelated interests (Moravcsik 1998). On the other hand, supranationalists and governance advocates argue that in the multi-layered and differentiated European institutional setting power has been dispersed away from central governments: upwards to the supranational level, downwards to sub-national jurisdictions and sideways to public and private networks of NSAs. This, together with the resource dependencies of EU institutions, increases the influence of NSAs, granting them some access to European policy making (Finke 2007; KohlerKoch 2005). Here the involvement of NSAs assumes a legitimizing and controlling function and contributes to democratic European governance. Although different studies arrive at different conclusions, the general view on interest groups in the EU is becoming more favourable (Balme et al. 2002; della Porta 2007). Many analysts claim that although domestic groups need to pursue a 'dual strategy' and promote their interests vis-à-vis both domestic and EU institutions (see Kohler-Koch 1997: 3), their overall lobbying strategies and logic of behaviour have become largely EU-dependent, thus Europeanized.

\section{History matters?}

For sociological institutionalism the major causal mechanism of institutional adaptation is isomorphism, which suggests that common interactions and a similar environment result in the convergence of rules and values. Authors relying on sociological institutionalism stress the importance of building a common European frame of meanings (Radaelli 2004) and focus on the dissemination of new ideas and concepts through European institutions (such as cooperative governance or subsidiarity). They study how norms are incorporated and internalized (Follesdal 1999). 
However, isomorphism poses a problem in explaining variations in the adaptation of different actors to the same institutional environment. Searching for responses to the variation in reactions to Europeanization, historical institutionalists propose to analyse institutional adaptation as a long, incremental process that takes place along historically developed paths conditioned by institutional traditions. The path dependency model emphasizes the importance of practices embedded over time and explains how the set of decisions an actor faces in any given circumstance is limited by decisions he has made in the past, even though past circumstances may no longer be relevant. It points to stickiness and inertia as characteristics of institutions. By way of example, in the process of Europeanization the German Länder and Spanish regions have acquired different adaptation modes and achieved different institutional results. Börzel explains differences in adaptation in terms of the distinct institutional cultures and patterns of interest mediation in both countries. Spanish competitive regionalism and a lack of trust between different levels of government, as well as between interest groups, have resulted in higher costs of adaptation to the EU than in the case of German cooperative federalism, where the culture of trust and costsharing has resulted in a smoother and easier adaptation of the German political system (Börzel 2002).

So far, systematic and comparative studies on the Europeanization of NSAs are confined to a limited number of member states (Börzel 2002; Falkner 2000; Schmidt 1999). It is therefore difficult to use these studies to draw any generalizations about non-state interest mediation in the EU as a whole. Some observations could, however, be drawn concerning the changing nature and agency of some interest groups in the process of Europeanization. A core hypothesis is often that the degree of fit between the domestic and European institutions is decisive for national adaptation to the EU. In the case of economic NSAs and interest groups, the different modes of interest intermediation represented by particular countries (pluralism, corporatism, statism) have a significant influence on the degree of fit/misfit between the EU and domestic interest groups (see Cowles 2001; Schmidt 1999). There is general agreement that the EU is based on a policy network type of interest mediation and that the extension of the EU's competence to new areas has been accompanied by the creation of newer, more diverse policy structures. Thus NSAs entering the European spectrum need to switch to different and often novel modes of interest mediation where nationally relevant solutions no longer serve their purpose. Moreover, the representation of non-economic NSAs in EU governance is still little explored and has been studied more in connection with the general debate on European civil society than from a comparative perspective. Therefore, apart from drawing the general conclusion that when European norms and ideas resonate with the internal norms of different actors, they are more likely to be incorporated into their existing structures and rules of conduct, it is difficult to determine the prevalent modes of Europeanization of NSAs in general and to establish their degree of fit. The historical and cultural heritage that constitutes crucial components of the circumstances in which different actors undergo the 
process of Europeanization renders institutional changes complex in nature and difficult to control. Existing institutions and norms are not simply replaced by new ones, but require a long, incremental process of selection and absorption during which some actors need to undergo deeper and more timeconsuming changes than others. Yet, unlike nation-states or national political parties, NSAs have a less rigid institutional structure and greater flexibility in coalition building. They are less government-dependent, and their logic of action is not based to such an extent upon national considerations. Therefore, it should be assumed that they possess a greater ability to adapt to internal norms, structure and agency in the European governance system. Moreover, whether they are pragmatic or ideologically charged might also influence how far NSAs are capable of Europeanization because such a move might be considered inappropriate in the eyes of their supporters. ${ }^{13}$

\section{Conclusion}

In this chapter I have tried to provide an analytical framework with which to investigate the impact of Europeanization upon NSAs. The variety of interests represented by different NSAs is a product of the complex processes of aggregation, articulation, politicization and operationalization of collective needs. And there is a multiplicity of organizational beings who work in the name of promoting interests. This diversity causes NSA responses to the impact of the EU to manifest themselves in a variety of possible actions. These may include absorption, accommodation, confrontation, rejection, the circumvention of national governments, cooperation, competition or simply discourse. They may further require organizational changes, agency changes, increased mobilization and interdependence between different NSAs at a supranational level; specialization and expertise; or new linkages with European actors beyond the national political system. The nature of European integration provokes a variety of reconfigurations in the structure and behaviour of NSAs. They adapt to their environments using a catalogue of patterns described and explained by different schools of neo-institutionalism. In rational action theory, the mechanism of Europeanization occurs through the redistribution of power resources, whereas in sociological approaches it occurs through socialization and learning. Rational choice states that organizations are bound together within networks by resource interdependence. These resource dependencies are the key variable in shaping the outcomes of adaptation to Europeanization, since they set the chessboard on which social and economic, private and public interests manoeuvre for advantage. Sociological and historical institutionalists, on the other hand, stress the importance of social norms, commonly shared values and historically developed paths of conduct that generate NSA responses to Europe. These responses may vary, depending on the tradition of interest mediation, the institutional and political culture of public discourse, the level of economic and democratic development of the member state or the liberal versus conservative profile of its social policy. There might be empirical examples that do not fit into the proposed scheme of 
analysis, yet the above factors should be taken into consideration when engaging in comparative studies.

A careful research design seeking to test for evidence of Europeanization can profitably incorporate various factors designed to compare NSA responses across member states or policy areas, bearing in mind that each political system represents a bundle of national-specific factors that condition particular NSA responses to the EU. Rational choice, normative approaches or historical institutionalism are not exclusive and they all contribute to the understanding of adaptation to Europeanization, which should be interpreted through a mix of organizing factors and principles. March and Olsen (2005) suggest that true believers in any of the three can reduce each of the other two to the status of a 'special case' of their preferred alternative. Yet, there is a tendency to supplement rather than reject alternative approaches. Moreover, apart from testing the institutional mechanisms within their 'rational', 'sociological' and 'historic' perspectives, political scientists need to bring the 'hated' politics back into European analysis. It is not easy either to assess whether Europeanization strengthens one group of actors at the expense of another, or to judge the possible impacts of Europeanization in terms of convergence or divergence. This theoretical gap could be filled by focusing on European cleavages, insider and outsider lobbying strategies of NSAs, patterns of contestation among European NGOs, and the reasons for the democratic deficit. In other words, we should study the nature of European NSA realpolitik, which, one might assume, affects the impact of Europeanization to a great extent.

Finally, one inevitable question arises concerning the Europeanization of NSAs and the democratic deficit: whether and to what extent NSAs are empowered by their roles as agents of Europeanization? It would be a task exceeding the scope of this chapter to analyse the agential role of NSAs in Europeanizing civil society. However, it is important to acknowledge that NSAs are the mediators between the EU and the people, since they were created directly by the people and for the people, for the protection of their interests. NSAs should thus be expected to act as socializing agents and opinion leaders for their grassroots and supporters while their organizational elites, instead of being just an 'emerging polyglot Euro elite' (Guiraudon, cited in Imig and Tarrow 2001), would engage in a process of translating Europe and making it 'a grammar in use' for the different segments of European society.

Depending on what is actually lobbied for and needed from Europe in terms of European policy and governance, this area should be made intelligible to citizens, ensuring conscious and democratic aggregation, articulation and participation in the pursuit of social interests at the European level.

\section{Notes}

1 In 2009, there were 1,316 EU-level interest representatives on the EC register, with approximately 60 per cent stemming from business and trade associations and the rest representing diffuse or public interests. See https://webgate.ec.europa.eu/transparency/regrin/consultation/statistics.do. 
2 For a general introduction to the issue of civil society and public space see Spini's chapter in this volume.

3 See Durkheim's (1999) distinction of functional groups.

4 Compare this with Godsäter and Söderbaum's conceptualization of civil society in their chapter in this volume.

5 The same definition is used by Itçaina in his chapter in this volume.

6 A social actor is an individual, group or institution that plays a certain social role in a particular social situational context and influences other actors. In such interactions all actors are seen as social actors.

7 The neo-institutional perspective can be divided into three main strands which are discussed in this chapter: rational choice institutionalism, sociological institutionalism and the historical perspective; see Marsh and Stoker (2002).

8 The term rational choice is used by the main new institutionalism theorists, March and Olsen, whereas Tania Börzel prefers the resource dependency model, which I use in my chapter. For the different resource dependency approaches see Putnam (1988); Rhodes (1997).

9 The mobilization and symbolic factors are discussed together since they are closely interdependent. The remaining four are: the financial factor, human capital, the institutional factor, and access to public goods, structure and coordination. See Sroka (2004).

10 See http://cordis.europa.eu/fp7/what_en.html.

11 For more on symbolic resources and their influence on interest group policy see Sroka (2004).

12 For more information see www.concordeurope.org/.

13 For example, a left-wing workers' organization might cooperate with some business sector organizations or with a political party in order to come to a wage agreement. This might be perceived by some part of the grassroots as a betrayal of the organization's principles and ideals.

\section{References}

Balme R., D. Chabanet and V. Wright (eds) (2002) L'Action collective en Europe/Collective Action in Europe, Paris: Presses de Science Po.

Börzel, T. (1999) 'Towards Convergence in Europe? Institutional Adaptation to Europeanization in German and Spain', Journal of Common Market Studies 37(4): 573-96.

Börzel, T. (2002) States and Regions in the European Union. Institutional Adaptation in Germany and Spain, Cambridge: Cambridge University Press.

Börzel, T. (2005) 'Europeanization: How the European Union Interacts with its Member States', in S. J. Bulmer and C. Lequesne (eds), The Member States of the European Union, Oxford: Oxford University Press, pp. 45-69.

Börzel, T. and T. Risse (2000) 'When Europe Hits Home: Europeanization and Domestic Change', European Integration Online Papers 4(15). Online. Available at http://eiop. or.at/eiop/texte/2000-015a.htm (accessed 16 March 2009).

Bulmer, S. (2007) 'Theorizing Europeanization', in P. Graziano and M. Vink (eds) Europeanization: New Research Agendas, Basingstoke: Palgrave Macmillan, pp. 46-58.

Cowles, M. G. (2001) 'The Transatlantic Business Dialogue and Domestic BusinessGovernment Relations', in M. G. Cowles, J. A. Caporaso and T. Risse (eds), Transforming Europe: Europeanization and Domestic Change, Ithaca NY: Cornell University Press, pp. 159-79.

della Porta, D. (2007) 'The Europeanization of Protest: A Typology and Empirical Evid- 
ence', in B. Kohler-Koch and B. Ritterberg (eds), Debating the Democratic Legitimacy of the European Union, Lanham, Md.: Rowman and Littlefield, pp. 189-208.

Dobre, A. M. (2005) 'Europeanization and Domestic Territorial Change: The Spanish and Romanian Cases of Territorial Adaptation in the Context of EU Enlargement', Journal of Southern Europe and the Balkans 7(3): 351-66.

Dunleavy, P. (1991) Democracy, Bureaucracy and Public Choice. Economic Explanations in Political Science, London and New York: Harvester Wheatsheaf.

Durkheim, E. (1999) O podziale pracy spolecznej, Warsaw: PWN.

Eising, R. (2008) 'Interest Groups in EU Policy-making', Living Reviews in European Governance 3(4). Online. Available at www.livingreviews.org/lreg-2008-4 (accessed 13 March 2009).

European Commission (2000) 'The Commission and Non-Governmental Organisations: Building a Stronger Partnership', Commission Discussion Papers, COM(2000) 11 final, Brussels: Commission of the European Communities. Online. Available at http://ec. europa.eu/civil society/ngo/docs/communication en.pdf. 3 (accessed 24 July 2008).

European Commission (2001) 'European Governance', White Paper, COM(2001) 428 final, Brussels: Commission of the European Communities. Online. Available at http:// eur-lex.europa.eu/LexUriServ/site/en/com/2001/com2001 0428en01.pdf. 3, 4.1 (accessed 22 July 2008).

Falkner, G. (2000) 'Policy Networks in a Multi-level System: Convergence Towards Moderate Diversity?', West European Politics 23(4): 94-120.

Featherstone, K. (2003) 'Introduction: In the Name of Europe', in K. Featherstone and C. M. Radaelli (eds), The Politics of Europeanization, Oxford: Oxford University Press, pp. 3-26.

Featherstone, K. and C. Radaelli (2003) The Politics of Europeanization, Oxford: Oxford University Press.

Finke, B. (2007) 'Civil Society Participation in EU Governance', Living Reviews in European Governance (2). Online. Available at http://europeangovernance.livingreviews. org/Articles/lreg-2007-2/ (accessed 29 January 2009).

Follesdal, A. (1999) 'Subsidiarity and Democratic Deliberation', Arena Working Papers. Online. Available at www.arena.uio.no/publications/wp99_21.htm (accessed 23 April 2009).

Galbraith, J. K. (1998) The Affluent Society, New York: Mariner Books.

Imig, D. and S. Tarrow (2001) Contentious Europeans: Protest and Politics in an Emerging Polity, Lanham, Md.: Rowman and Littlefield.

Jacobsson, K. and H. Johansson (2007) 'The Micro-politics of the OMC Process: NGO Activities in the Social Inclusion Process in Sweden'. Online. Available at http:// digitalcommons.law.umaryland.edu/cgi/viewcontent.cgi?article=1001\&context=soceur o (accessed 22 April 2009).

Keck, M. E. and K. Sikkink (1998) Activists beyond Borders, Ithaca, NY: Cornell University Press.

Kohler-Koch, B. (1997) 'Organized Interests in the EC and the European Parliament, European Integration Online Papers 1(9). Online. Available at http://eiop.or.at/eiop/ texte/1997-009a.htm (accessed 22 July 2008).

Kohler-Koch, B. (2005) 'European Governance and System Integration', European Governance Papers C-05-01. Online. Available at www.connex-network.org.eurogov (accessed 12 April 2009).

Keating, M. (2004a) 'European Integration and the Nationalities Question', Politics and Society 31(1): 367-88. 
Keating, M. (2004b) 'Regions and the Convention on the Future of Europe', South European Society and Politics 9(1): 192-207.

Ladrech, R. (1994) 'Europeanization of Domestic Politics and Institutions: The Case of France', Journal of Common Market Studies 32(1): 69-88.

Ladrech, R. (2001) 'Europeanization and Political Parties: Towards a Framework for Analysis', Party Politics 8: 389-403. Online. Available at http://ppq.sagepub.com/cgi/ reprint/8/4/389 (accessed 20 March 2009).

Lindblom, Ch. E. and E. J. Woodhouse (1993) The Policy Making Process (Third Edition), Englewood Cliffs, NJ: Prentice Hall.

Malloy, M. (1997) 'Europe's Regions in a New System of Governance? The Case of Catalonia in Spain and the EU', European Union Studies Association. Online. Available at http://aei.pitt.edu/2669/ (accessed 22 March 2009).

March, J. G. and J. P. Olsen (1989) Rediscovering Institutions, New York: The Free Press.

March, J. G. and J. P. Olsen (1995) Democratic Governance. New York: Free Press.

March, J. G. and J. P. Olsen (2005) 'Elaborating the "New-Institutionalism", Centre for European Studies: Arena. Online. Available at www.arena.uio.no (accessed 20 January 2009).

Marks, G. and D. McAdam (1995) 'Social Movements and the Changing Structure of Political Opportunity in the European Union', European Union Studies Association (EUSA). Online. Available at http://aei.pitt.edu/7321/ (accessed 11 April 2009).

Marsh, D. and G. Stoker (2002) Theories and Methods in Political Science, New York: Palgrave Macmillan.

Matei, A. (2004) 'Evoluția administrației europene. Concepte şi abordări fundamentale', Drepta comunitar 3: 29-43.

Matei, A. and L. Matei (2007) 'Globalization and Europeanization. A Projection on a European Model of Public Administration'. Online. Available at http://ideas.repec. org/a/agr/journl/v4(521)y2008i4(521)p33-52.html (accessed 19 January 2009).

Moravcsik, A. (1998) The Choice for Europe: Social Purpose and State Power from Messina to Maastricht, New York: Cornell University Press.

Olsen, J. P. (1997) 'European Challenges to the Nation State', in B. Stteunenberg and F. Van Vught (eds), Political Institutions and Public Policy, The Hague: Kluwer Academic Publishers, pp. 157-88.

Olsen, J. P. (2002) 'The Many Faces of Europeanization', Journal of Common Market Studies 40(5): 921-52.

Peterson, J. (1995) 'Decision-making in the European Union: Towards a Framework for Analysis', Journal of European Public Policy 2(1): 69-93.

Peterson, J. (2003) 'Policy Networks', IHS Political Science Series 90. Online. Available at http://aei.pitt.edu/764/01/pw_90.pdf (accessed 3 March 2009).

Putnam, R. (1988) 'Diplomacy and Domestic Politics: The Logic of Two-level Games', International Organization 42(3): 427-60.

Radaelli, C. (2003) 'The Europeanization of Public Policy', in K. Featherstone and C. M. Radaelli (eds), The Politics of Europeanization, Oxford: Oxford University Press.

Radaelli, C. M. (2004) 'Europeanization: Solution or Problem?', European Integration Online Papers 8(16). Online. Available at http://eiop.or.at/eiop/texte/2004-016a.htm (accessed 18 April 2009).

Ramon i Sumoy, R. (2005) 'Multi-level Governance in Spain: Building New Patterns of Subnational Participation in the EU Policy-making', VII Congreso Español de Ciencia Política y de la Administración: Democracia y Buen Gobierno, Madrid. Online. Available at www. 
aecpa.es/congreso_07/archivos/area5/GT-20/RAMONiSUMOY-Ricard(UAB). pdf (accessed March 2007).

Rhodes, R. (1997) Understanding Governance: Policy Networks, Reflexivity and Accountability, Buckingham: Open University Press.

Risse, T., M. G. Cowles and J. Caporaso (eds) (2001) Europeanization and Domestic Change, Ithaca, NY: Cornell University Press.

Roller, E. (2004) 'Conflict and Cooperation in EU Policy-Making: The Case of Catalonia', Perspectives on European Politics and Society 5(1): 81-102.

Ruzza, C. (2004) Europe and Civil Society. Movement Coalitions and European Governance, Manchester: Manchester University Press.

Ruzza, C. (2006) 'EU Public Policies and the Participation of Organized Civil Society', Working Papers of the Dipartimento di studi sociali e politici, University of Milan.

Schmidt, V. (1999) 'National Patterns of Governance under Siege: The Impact of European Integration', in B. Kohler-Koch and R. Eising (eds), The Transformation of Governance in the European Union, London: Routledge.

Schmitter, P. C. (2002) 'Participation in Governance Arrangements: Is There Any Reason to Expect It Will Achieve "Sustainable and Innovative Policies in a Multi-level Context"?', in J. Grote and B. Gbikpi (eds), Participatory Governance: Political and Societal Implications, Opladen: Leske and Budrich, pp. 51-70.

Sroka, J. (2004) Polityka organizacji pracodawców i przedsiębiorców, Wrocław: Wydawnictwo Uniwersytetu Wrocławskiego.

Vink, M. (2002) 'What Is Europeanization? And Other Questions on a New Research Agenda', paper for the Second YEN Research Meeting on Europeanization, University of Bocconi, Milan. Online. Available at www.essex.ac.uk/ECPR/standinggroups/yen/ paper_archive/2nd_yen_rm_papers/vink2002.pdf(accessed 12 April 2009).

Warleigh, A. (2001) 'Europeanizing Civil Society: NGOs as Agents of Political Socialization', Journal of Common Market Studies 39(4): 619-39.

Warleigh, A. (2003) Democracy and the European Union: Theory, Practice and Reform, London: Sage.

Weaver, R. K. and B. A. Rockman (eds) (1993) Do Institutions Matter? Government Capabilities in the United States and Abroad, Washington, DC: Brookings. 


\title{
5 Between localisation and \\ Europeanisation
}

\section{Non-governmental organisations in Bosnia and Herzegovina}

\author{
Erica Panighello
}

\section{Introduction}

The Thessaloniki European Council held in June 2003 formalised the promise of European integration to Bosnia and Herzegovina $(\mathrm{B} \& \mathrm{H})$ and the rest of the 'Western Balkans'. These countries could not become involved in the European project in the aftermath of 1989, but their current route is depicted in the following terms: 'The future of the Balkans is within the European Union' (European Commission 2003). Since then, widespread trust in the EU's so-called 'transformative impact' has progressively diminished. As far as $\mathrm{B} \& \mathrm{H}$ is concerned, the main problem turned out to be instability caused by internal nationalisms, whose effects are hindering the democratic (and European) transition of the country. The EU's assumption regarding membership can basically be summarised by the formula 'membership = domestic pacification', even if this equation is hardly explored: research about the impact of the EU on the Balkans, compared to that covering previous EU enlargement, is still in its infancy (Elbasani 2008). In other words, in what ways can the EU's gravitational model support (or transform) the current domestic governance of $\mathrm{B} \& \mathrm{H}$, whose main obstacle to membership is implementation of the ethnic principle into the political and social infrastructure of the country?

Ethnos and demos are two alternative patterns of self-organisation for several polities (and many succeed in finding peaceful reconciliation between them). In the Bosnian case, we can arguably state that the two principles are embraced by the domestic nationalist leaderships (Serbian, Bosniak and Croatian) and the EU respectively. My interest in civil society organisations or, more specifically, NGOs in $\mathrm{B} \& \mathrm{H}$ arose during a number of visits to the country, where I happened to meet some NGO members whose outlook was anything but nationalistic. Despite the aggressive nationalistic rhetoric of political elites, there are some societal spaces where a more inclusive pattern of citizenship is proposed or better yet - concretely practised, often in a hidden and silent way. NGOs constitute today a sort of informal 'counter-elite' in B\&H in 'ways of doing things', thanks to their focus on the person instead of the group member. This attitude fits perfectly with the emphasis on respect for individual rights and freedoms stressed by the EU, which is often neglected by the formal practices that prevail in the Bosnian socio-political environment. 
Given these premises, and considering the prominent role that the EU is playing in $\mathrm{B} \& \mathrm{H}$, this research focuses on the personal attempts of NGO staff members to reconcile the two alternative patterns of regulatory behaviour provided by inclusiveness (the model explicitly suggested by the EU) and exclusiveness (the model prevailing in the domestic arena). NGOs have been selected because, given the specificity of the Bosnian context, they emerge in the wider realm of civil society through their connections with the international environment (in its broader meaning: foreign governments, transnational NGOs, international governmental agencies, informal relationships with foreign actors, and so on), whereas other kinds of 'traditional' civil society organisations (trade unions, war veterans' associations, sport clubs, and so on) do not have such connections.

The empirical findings were collected through 27 semi-structured, face-toface interviews with NGO staff members that took place in the four main cities of B\&H - Sarajevo, Tuzla, Banja Luka, Mostar - in February, April and June 2008. The dimensions investigated and indicators are summarised in Table 5.1.

With regard to nationalism, this wide concept usually encompasses three distinct aspects: sentiments, doctrines and politics (Breuilly 1999: 43). Considering the focus of this research on 'issues such as national identity or culture or ways of life' (Breuilly 1999: 43), nationalism is meant in terms of 'sentiments', that is, it is an identity bulwark which is both a collective and an individual phenomenon (Jenkins 2008). The basic assumption at stake is that ethnicity - if appropriately channelled through a constructive dialogue - can strengthen the democratic

Table 5.1

\begin{tabular}{|c|c|}
\hline Dimensions & Indicators \\
\hline Ethno-nationalism & $\begin{array}{l}\text { - ethno-national self-definitions (voluntary, not required) } \\
\text { presence of 'ethno-nationalism' when asked to list B\&H's } \\
\text { problems } \\
\text { references to ethno-national issues when talking about the other } \\
\text { two dimensions }\end{array}$ \\
\hline Civil society & $\begin{array}{l}\text { - personal understanding of the concept } \\
\text { - NGOs' role in Bosnian context } \\
\text { - perceptions of distinctness from 'ordinary citizens' } \\
\text { - awareness of the commitment: working at NGOs as 'mission' vs } \\
\text { 'job' }\end{array}$ \\
\hline Europeanisation & $\begin{array}{l}\text { - } \text { spontaneous definitions of Europe/EU } \\
\text { membership of the country } \\
\text { - personal understanding of some key expressions of the EU's } \\
\text { rhetoric (European values, Europe of citizens, normative power) } \\
\text { contacts/relationships with colleagues or friends living in } \\
\text { European countries } \\
\text { - relevance/frequency of the subject Europe in working activities } \\
\text { and in private life }\end{array}$ \\
\hline
\end{tabular}




\section{E. Panighello}

process within a given pluralistic system, while ethnicisation (the politicisation of ethnicity) challenges the very core of a democratic system, that is the respect for differences in the achievement of the common good. As Schöpflin puts it, ethnicity 'can undermine democracy when either the state or civil society or both is too weak to contain it and thereby ethnic criteria are used for state and civic purposes' (1997: 14). Finally, it is useful to demarcate the phenomenon in question as 'ethno-nationalism', in order to avoid misunderstanding nationalism as 'patriotism' or 'civic nationalism' - that is, loyalty to one's own state (Connor 1995).

I refer to the EU as a normative power, a global actor 'founded on and [which] has as its foreign and development policy objectives the consolidation of democracy, rule of law, and respect for human rights and fundamental freedoms' (Manners 2002: 241). EU institutions consider NGOs as 'ideal partners' in the process of democracy- and civil society-building, especially as far as external relations and enlargement policies are concerned (European Commission 2000). As will become evident, a constructivist approach has shaped this qualitative research, since constructivism allows us to investigate the 'transformative impact' of the European project on agents' narratives, identity and preferences (Christiansen et al. 2001; Checkel 2001). Europeanisation is defined here as an 'interactive process', which can concern people even 'without specific pressure from Brussels' (Radaelli 2004: 4). It has been investigated through the narratives of Europe, which NGO members construct and interiorise.

\section{Civil society in a transitional country}

The crucial role of civil society in preserving and strengthening democratic regimes is nowadays unquestionable. In spite of different approaches, from de Tocqueville onwards - and after quite a long period of indifference towards the issue - the richness of associational life is unanimously considered as a marker of the good health of a polity, a watchdog against the possible degeneration of majority procedures, daily training wherein citizens can concretely improve their civic attitudes. ${ }^{1}$ Following Cesareo, we could say that the term 'civil society' maintains today a high level of ambiguity, since it holds at the same time the meanings of 'political slogan, analytical concept, and normative ideal' (Cesareo 2003: 6).

After the collapse of communism, a vacuum occurred on various fronts; the political culture of ethno-nationalism readily filled it up, demolishing at the very start proposals for any alternative model of citizenship (Schöpflin 2000), and destroying the idea of the 'return of the citizen', considered as the very core of the development of endogenous civil societies. From a social point of view, communism was not as impermeable a system as it seemed. Bianchini notes the existence of an 'underground society' in Yugoslavia which emerged in the 1960s; independent intellectuals and feminist and ecological movements are examples of the dissent against the regime, even if they could not succeed in gaining individuals' loyalty when communism collapsed (Bianchini 2000). In 
B\&H, the 1992-95 conflict aggravated the complex path to democratic transition, destroying the civic initiatives of citizens' groups aimed at promoting alternative forms of citizenship founded on universalistic (instead of ethnic) criteria (Kaldor 1998; Andjelić 1998).

The role of civil society during the European communist regimes and during the first stages of democratic transition is still debated (Seligman 2002; Delli Zotti 1991; Bianchini 2000). The ideocratic denial of any individual and collective form of self-organisation imposed by socialist rule represents today a heavy heritage for the new democracies, whose citizens are often described as 'apathetic', 'atomised' and 'fatalist'. If the concept of civil society, from a philosophical and historical perspective, is inextricably connected to the rise of the liberal-democratic political system (Gellner 1997), how can we approach the 'civil society project', as defined by Michael Walzer (1997), in contexts with different backgrounds? The present research proposes a twofold path in order to deal with this general issue.

First, one important trend, which invites us to consider civil society as a locus - instead of a medium - of democratisation could be isolated from the abundant literature on civil society: "Voice, rather than votes, is the vehicle of empowerment' (Chambers 2002: 99). This approach does not consider civil society as a 'conveyor belt' towards political institutions, but as a terrain of democratisation in itself. Far from being a reductive way of understanding civil society potentialities, this approach is, in my view, a very appropriate means of highlighting NGO practices in the transitional B\&H. These fragments of civil society have emerged despite the lack of a comprehensive culture of civil society. The usual criticism they draw - their limited capacity to spread their good practices to the rest of society, both civil and political - can be put in perspective by emphasising their own empowerment as democratic societal agencies. After the failure of the political and economic agencies in the complex normalisation of the country, much trust has been placed on societal actors. A realistic analysis ought to avoid both considering their contribution as a panacea and underestimating their daily efforts in implementing non-discriminatory practices.

Second, methodologically we should consider that a 'low associative density' (an indicator usually employed to emphasise the weakness of many new East European civil societies) does not necessary imply a functional weakness of a given civil society. Other characteristics such as the quality of the organisations and their connectedness (in this case study, particularly with the international arena) can be much more useful for understanding the state of the art of civil society in transitional countries (Kubik 2005). At this point, we can proceed by outlining the main characteristics of the organisations' environment in B\&H, since these should be considered 'not only an additional matter of influence but constitutional part of their origin, emergence, being and future development' (Herrmann 1998: 108). 


\section{NGOs in Bosnia and Herzegovina: limits and capacities}

Generally speaking, since the end of the Cold War the number of national and international NGOs all around the world has seen a huge growth; to the traditional fields of intervention like humanitarian aid or disaster relief, new sectors have been added, like conflict prevention, democracy promotion or ecologic programmes. ${ }^{2}$ The low degree of homogenisation of the non-governmental sector causes some difficulties in reaching an unequivocal definition of 'NGO'. Despite the huge variety of typologies, missions and internal structures, NGOs are first of all civil society organisations. This means they are organised, private, non-profitdistributing, self-governing and voluntary entities (Salamon 1997: 61). In the wide realm of private, voluntary and not-for-profit organisations, a useful distinction has been provided by A. M. Rose between 'expressive associations' and 'socialinfluence associations' (Meister 1971). Through the first type people satisfy their own interests (sport clubs, chess associations, and so on), while through the second individuals aim at modifying the surrounding environment. It is this second kind of association we refer to when discussing NGOs. Even more specifically, it is possible to define NGOs operating in $\mathrm{B} \& \mathrm{H}$ today on the basis of their commitment to goals like 'intercultural dialogue, human rights promotion, peace, environment protection', a field that is often synthesised through the formula 'development promotion' (Mascia 1991: 3). NGOs usually prompt an idea of genuineness and good practice, since they are triggered by popular action (bottom-up initiatives), without being subject to government directives, and they are not market-driven but - as often pointed out in specialist literature - 'value-oriented'.

Turning back to $\mathrm{B} \& \mathrm{H}$, it is worth noting that the 'set of NGOs' has become synonymous with 'civil society'. In the country, the huge growth of NGOs started in conjunction with the war: these new social actors quickly took place of the 'anti-politics' social movements which emerged during the 1980s in most of the East European regimes (Kaldor 1998). Compared to the previous protagonists of the social scene, NGOs immediately looked more professional, skilled and organised, overshadowing any other expression of social self-organisation and monopolising the international community's attention (and resources), even if the best-informed analysts do not omit to report that 'In Bosnia there are many NGOs but little civil society’ (Serwer, quoted in Karajkov 2007). The Organisation for Security and Cooperation in Europe (OSCE) Mission in B\&H (2003) describes civil society mostly in terms of a 'broad range of organisations', cutting away from the definition all the other modalities through which civil society can express itself (spontaneous demonstrations, social movements, nonformal groups, and so on). The same trend can be seen in NGO members' opinions. When asked to give a picture of the 'civil society sector' in their country, most of them only described the role of NGOs; when expressly asked to evaluate the impact of - say - spontaneous demonstrations on the process of democratisation, some of them questioned whether mass protests or informal citizens' initiatives could be included in the realm of civil society, given their 'not organised' and 'not professional' nature. 
Some 7,000 NGOs are formally registered in the country today, even if only half of them are really operative (USAID 2007), implementing projects that range from rural development to human rights protection, from civil society empowerment to advocacy initiatives. With regard to their foundational initiatives, we can schematically divide NGOs into 'local' (domestic input, local working staff), 'international' (local expressions of foreign national/international NGOs, mixed working staff), and 'hybrid' (local branches of a foreign NGO which rise after the departure of foreign staff members). We can now examine some peculiarities of the NGO sector in $\mathrm{B} \& \mathrm{H}$.

\section{Substituting for the state}

Although the contribution made by NGOs can hardly be underestimated, the other side of the coin is to be found in the curtailment of state intervention, as both cause and effect of the NGO boom. Some analysts are very critical of this fact, because after half a century of state predominance, the balance is now going the other way, weakening the role of state institutions (Karajkov 2007). Not only financial resources, but also skills and professional capacities, are potentially drained from the governmental to the non-governmental sector, due to the higher salaries that NGOs can offer - thanks to the international support. It should be said, however, that NGOs provide services that the post-conflict state - still institutionally trapped by the mutual veto of different national interests - cannot manage to provide for its citizens. The main point here is that NGOs' beneficiaries are not subject to universalistic criteria of selection, and they are not addressed as 'right bearers', as in the case of welfare policies provided to citizens (Ranci 1991). Furthermore, since NGOs are usually sensitive to their donors' attitudes and preferences about the fields of intervention, the risk of their becoming more donor-oriented than needs-oriented is always latent. Needless to say, most international funding is currently channelled through NGOs. This is for pragmatic reasons: NGOs are efficient and quick in mobilising financial, human and technical resources in a short time; they are oriented to the grassroots, so they can easily identify the real needs of the recipient community, and so on. There are also some 'ideological' reasons - the good reputation of the sector, its 'non-governmental' status which implies political independence, and so on. This phenomenon undoubtedly curtails the support which would otherwise be reserved for state agencies, and it generates heavy forms of foreign dependency, another feature of the NGO sector in the country.

\section{Dependency on international donors}

Although the level of international funding is slowly decreasing, the international community remains the main financial supporter of NGO activities. The sector would at present have difficulty relying solely on private donations (philanthropy) and public funds. The overwhelming economic depression is only one reason, and we should add the removal of political institutions from a sector often perceived as 
the 'fifth column' of foreign interests. Things look better at the local level: municipalities more often recognise the role played by NGOs and assist in financing them, even if their contribution remains modest compared with demand. Relying on external support brings other important consequences: strong competition for (diminishing) resources results in rewards for the 'best' NGOs, those which are more skilled and professional, and those more familiar with the functioning of international networks and with the mechanisms of fund-raising. This works to the detriment of small NGOs, which traditionally are more grassroots-oriented and less responsive to the standards required by big donors. Consequently, those NGOs that manage to continue their activities thanks to international support become detached from the domestic terrain, making their connection with local government (and local market actors) increasingly tenuous (Karajkov 2005).

Finally, according to some authors, external interventionism brings important side-effects for the endogenous development of civil society, since it progressively usurps those 'watchdog functions' which, in a democratic framework, should belong mainly to civil society (Belloni 2001). The main assumption of the international community has proved wrong: the development of NGOs has not automatically resulted in the empowerment of the whole civil society sector (Fischer 2006: 456). Nevertheless, I think we should consider a societally positive aspect which is often neglected: the international community provides Bosnian civil society's actors with several of the means to overcome the local/ global divide, granting them concrete opportunities to do so (NGOs' networks, exchanges, and so on).

\section{'Hostile' social environment}

Very often NGOs' efforts are not appreciated by the population (and often they are not even known); their leaders must work 'on behalf of a public that frequently complains, but which lacks both a belief that change is possible and an understanding of how to change things' (OSCE 2003: 2). ${ }^{3}$ In the words of one NGO staff member, 'Friends make fun of me, they say that I earn money without doing anything!' According to another interviewee who conducted research into the impact of NGOs in some of B\&H's municipalities, people usually perceive NGOs as private enterprises, aimed at paying salaries to their staff members (if not at making a profit), or as the international community's supplements without any domestic substratum. If a certain population has not been given the opportunity to have a voice and to take an active part in the social and public space for a long time, it will need to make more effort to internalise more participative patterns of behaviour. At the same time, the frustration of those actors who feel trapped between their personal efforts and the community's indifference is perfectly understandable. To quote one interviewee, 'I sometimes think we will never change anything ... we organise campaigns, we lobby ... but to have any impact on the public opinion is almost impossible here!'

Empirical data showed two different ways to understand one's own engagement in an NGO. On the one hand, we find those I call pragmatic workers; that 
is, people who do their job professionally but without explicitly claiming to have (or being aware of having) any impact on the surrounding socio-political environment: 'It is not my duty to go directly to persuade people ... I work for and with our beneficiaries, that's all!' On the other hand, there are the activists, those who believe their work (or, better, their mission) must affect wider dynamics, starting from their personal daily relationships: 'I've decided to do something, regardless of how difficult or useless it can be ... my family and my friends do not understand what I feel as a front-liner, but I think no one but ourselves can change anything in this lethargic country'.

Even if proposing generalisations on the base of qualitative surveys is often a sensitive operation, my data suggest that self-perceptions of people's roles are related to the typology of the organisation they belong to. We are more likely to find 'pragmatic workers' in international NGOs, while 'activists' are more numerous in local NGOs, and they are usually the founders of the organisation. On this basis, we can suppose that NGOs constitute a privileged terrain for individuals who are already predisposed to forms of civic engagement, and who profit from the support given to this sector by the international community, in the absence of alternative ways through which to channel their commitment.

\section{Working opportunity}

Due to the dramatic economic conjuncture in $\mathrm{B} \& \mathrm{H}$, the $\mathrm{NGO}$ sector seems to represent for many people a kind of 'employment agency' rather than a genuine will to be actively engaged in building civil society. It is a fact that NGOs offer job opportunities for many educated young people who would not have alternatives in any other sector. I would like to add that many actors (and scholars) of civil society consider volunteerism to be a crucial component of associational initiatives or membership: if you have no monetary benefits, your activity will be more genuine. ${ }^{4}$ This may be true, but it should not lead us to underestimate the effects which derive from such an activity, whatever to the underlying motivation. Moreover, by inverse reasoning, the lack of material incentives is not a guarantee of disinterestedness. Many other reasons can support the decision to become involved in an NGO (personal reputation, social prestige, hope for future recruitment, and so on). Therefore it may not always be relevant - at least, for my concerns here - why these actors engage in some activities (because of receiving a salary or because of a need for civic-ness or personal satisfaction); rather, we should focus on how they do it and what results they get. After all, the empirical survey illustrates that there is no difference in self-awareness of societal actors on the basis of the 'status' of NGOs' members (workers vs volunteers). The difference, as indicated above, is mainly attributable to personal features and (most likely) to the local $v s$ international dimension of the organisation concerned. 


\section{Narratives of Europe in a European periphery}

In order to make B\&H develop into a 'functional, stable and viable state', since the beginning of the conflict the EU has adopted a multifaceted approach through various programmes, progressively shifting its intervention from the initial humanitarian assistance programmes to institution- and capacity-building and economic recovery sectors. ${ }^{5}$ As far as civil society initiatives are concerned, several pieces of research outline a real entrepreneurship in EU institutions, in providing open access points for their active involvement (Sanchez-Salgado 2006). Besides the hard conditionality adopted by the EU when dealing with its institutional interlocutors from candidate countries, we can find a softer conditionality addressed to non-state actors, where opportunities and resources are allocated in order to promote 'contacts and cooperation of domestic NGOs with their partners in Europe' (Raik 2006: 14). Indirectly, there is also wider European integration from below. Persuasion, socialisation, peer pressure and learning are the leitmotifs of this 'soft conditionality' (Checkel 2000); the EU does not assume the role of 'hegemonic actor', as it does in the case of political and economic adaptation to the acquis, but it has created a set of opportunities, setting civil society organisations free to decide the modalities of their reciprocal interactions.

At a first sight, all interviewees exhibited at least one of the indicators of structural Europeanisation (Della Porta and Caiani 2006: 177), namely cooperation with other European NGOs, experiences abroad, and relationships with friends living in other European countries. Most exhibited all of them. If we assume that the process of European identity formation in many cases is based upon 'constant relationships between citizens, governments, interest groups and many other actors', this process seems to be already in motion in the case of my target group (Della Porta and Caiani 2006: 181). I identified two main frames about the 'narratives of Europe' theme. First, there is a valorial frame. It includes both positive images of Europe, as a 'family', as something that 'can provide people with a higher ideal', something to be 'proud of'; and negative, like 'ambivalence and confusion'. Second, there is an instrumental frame. It also includes positive attitudes, seeing Europe as a 'watchdog' against bad politicians, and as offering 'more possibilities and opportunities', 'stability', 'security', 'solution to the isolation'; and negative ones, like 'new rules, new taxes', 'too much bureaucracy' and 'double standards'. This instrumental image brings to mind the conception of Europe as a 'cold project' (Nevola 2007: 31), something aimed not at awakening great passions but at defending interests and guaranteeing opportunities.

The 'European values' item generated very interesting discussions. Its vagueness brought the interviewees each time to select those definitions closer to their social worlds and their personal experiences. In any case, none of them had a 'doctrinal' outlook, and the findings can be basically divided into two main understandings. On the one hand, they illustrate a normative frame, which emphasises the realm of rights and liberties, identifying European values with 
'respect for diversity', 'human rights', 'democracy', 'cosmopolitanism', 'living together' and 'living without boundaries'. Particularly relevant for what concerns us here, when asked to list some of these values three respondents expressly named recognition of the individual as one of the more meaningful for them. In their view, Europe is a place that allows people to be themselves, apart from their ethno-nationalist belonging. In the words of one interviewee: 'I'm a very individualistic woman, and people here don't like individualists!' Second, they illustrate a technical frame. It includes all the definitions revolving around the concept of European standard. Like any other potential candidate country to EU membership, B\&H must fulfil specific prerequisites in several sectors, and all its citizens have become acquainted with the term 'standard', widely used in the public sphere.

It is worth noting that analysis of the survey findings shows a sort of dyscrasia between the personal conceptions of the interviewees and one of the main classifications which have been proposed in academia. Ian Manners (2002) indicates a twofold typology of EU normative bases: core norms, which include peace, liberty, democracy, rule of law, respect for human rights and fundamental freedoms; and minor norms including social solidarity, anti-discrimination, sustainable development and good governance. The discrepancy concerns one norm in particular, anti-discrimination, which one-third of the interviewees mentioned when asked to provide some examples of 'European values'. In this way, they reveal as 'central' a value that is considered 'minor' within 'the constitution and the practices of the EU' (Manners 2002: 242). According to Klaus Eder (2005), the 'peripheral Europeans' - those who claim to be Europeans but are not yet fully recognised by the 'core Europeans' as part of their group - develop wider 'conceptions of a European identity', mobilising their national past and transferring it into a cultural (non-political) notion of Europe. An empirical corroboration of Eder's thesis can be provided by those same NGO members who evaluate anti-discrimination as a fundamental principle of the EU regulatory framework. In this case, they stress the equality of citizens (regardless of one's own ethnic background) which - in their view - constitutes an uncontroversial rule in Europe, even though it is still neglected in their country. In this way, they are raising to a 'European value' a principle that, as NGO members, they already implement in their daily work, underlining the fact that it would be decidedly easier to carry out anti-discriminatory practices in a 'European framework'.

\section{NGOs between ethnos and demos}

'Political misuse of ethnic and religious diversity' is indicated by the European Commission as one of the obstacles to a more intense development of civil society in B\&H (European Commission 2006: 15). Frequent statements by political leaders indicate the need to defend the national interests of the three constituent peoples, fostering inter-ethnic intolerance. Repercussions of these political divisions can be found, unfortunately, in most parts of the social structures of the country. The most paradigmatic examples are where schools have separate 


\section{2}

entrances for 'different' pupils. Self-definitions very rarely have an independent life in an ethnically constructed system. A refusal to be labelled according to ethnic belonging is always possible, until one has to deal with the most common daily affairs, like going to school or to hospital, searching for a job, voting, deciding whether to go to the 'other part' of the country, deciding whether to return to one's place of birth, meeting someone who understands from one's name what 'group' one belongs to, and so on.

As a regulatory principle of collective life, ethno-nationalism questions the legitimacy of the civil society project, at least as it is conceived within the liberal-democratic tradition (the realm of mediation between individual and social principles). In $\mathrm{B} \& \mathrm{H}$, different conceptions of civil society (civic vs ethnopolitical) jeopardise the potential partnership between societal and political actors (Sejfija 2006). What is the role of NGOs in such a framework? Collective identities - with their emphasis on exclusive practices - seem to be stifling in the view of all the people I interviewed. Pride in one's own traditions and culture never overwhelms respect for other belongings, and in many cases they are explicitly distanced from 'political extremisms'. Working for an NGO often helps to maintain this 'open-minded' outlook, since workers are regularly asked to interact with other people, and in general the statutory mission of these organisations actively promotes anti-discriminatory initiatives. Inclusive patterns are implemented in a direct way, through projects explicitly aimed at fostering interethnic dialogue, or in an indirect way, for example through the projects of those 'technical' NGOs which offer their services to each individual.

This sector is not representative of the whole civil society in $\mathrm{B} \& \mathrm{H}$, and its 'critical mass' is perhaps not yet sufficient to reverberate on all the social and political mechanisms which govern the country. Nevertheless, I think this sector is definable as a concrete locus of democratisation, where citizens are empowered through the duties they are expected to implement. Civil society's role consists not only of monitoring the state's performances, but also of protecting individual and social spheres from excessive state intervention: NGOs propose alternative channels and sets of values compared to those offered by the political rhetoric. Admittedly, people working or volunteering in the NGO sector are - as many of them like to make clear - 'privileged' compared to ordinary citizens: they have easier access to all sorts of information, and above all they can travel abroad more easily. Those working for an international NGO, for instance, are frequently required to convene in the organisation's country headquarters for numerous reasons (training, debriefing, study visits, and so on). In any case, formal and informal contacts with foreigners, often occurring within the working environment, can be of some help in getting a visa. Generally speaking, individuals who get involved in the NGO sector already possess, prior to their involvement, some particular features or skills that enable them to be mobilised. It is a virtuous circle: even given that NGOs are not the only source of individuals' various experiences, they nonetheless represent, in many cases, a positive mechanism which allows these specifically skilled people to remain in the mobility circuit. Considering that it is not unusual to hear expressions like 
'ghetto' or 'prison' from interviewees referring to their country, I think this is an aspect that should not be underestimated. Moreover, it has often been proved that contacts between individuals tend to generate less prejudiced behaviours, while contacts between groups tend to radicalise ethnic distance (MungiuPippidi 2006).

NGO members can arguably be defined as multipliers of that socialisation to inclusiveness suggested by European institutions or, more broadly, by the wider European associational structure which constantly interact with the domestic organisations in B\&H. For the European Commission, NGOs represent the ideal interlocutor for conveying a European message: given the specific context of $\mathrm{B} \& \mathrm{H}$, such a message is to be interpreted mainly in anti-nationalistic terms. In view of this wide purpose, the preference generally given by the EU to this kind of organisation is understandable, although it is to the detriment of more "traditional' expressions of civil society. Thus, for example, we are more likely to fund a microcredit project addressed at multi-ethnic communities than a monoethnic war veterans' association.

In the consciousness of NGO members, is Europe the realm of universalism rather than particularism, a place where no one would ask others 'what group do you belong to?' For some of them it is, for others it is Europe that should learn about how to live together. In any case, regardless of personal opinions, we can conclude that 'Europe matters' today in B\&H. To quote one interviewee, 'the only things we talk about in $\mathrm{B} \& \mathrm{H}$ are: how it was before the war, how it is after the war, and how it is in Europe'. Despite the fact that Europe does not always arouse positive opinions, it is recognised by almost all the interviewees that stronger European protection would contribute to removing ethnic boundaries, and to the definitive affirmation of the multicultural framework that has characterised Bosnia for decades. In the static situation that is slowing B\&H's progress towards full democratisation, a European framework - particularly with regard to the promotion of individual rights - is simply fundamental in a country still dominated by separate collective belongings, as well as support by European organisations, agencies and associations for the myriad civil initiatives which refuse to submit to ethno-nationalistic logics of behaviour.

\section{Notes}

1 It is obviously impossible to reproduce here the variety of possible positions. See, for instance, Chambers and Kymlicka (2002); Cohen and Arato (1994); Keane (1988); Gellner (1996); Seligman (1992).

2 For a very clear description of the types, limits, potentials and challenges of NGOs in the 'Age of Globalization', see Debiel and Sticht (2005). An interesting 'top-down' explanation for the spread of NGOs in the post-war period is provided by Reimann (2006).

3 For an overview of citizens' participation, see the research conducted by the Centres for Civic Initiatives $\mathrm{BiH}$ (2006) and the OSCE's Public Opinion Research (OSCE 2004).

4 The 'volunteerism rhetoric' (Melucci 1991) and the emphasis on 'free actions' are particularly strong in the Italian associational tradition. 


\section{E. Panighello}

5 For a detailed overview of the various programmes, see the enlargement section of the EU website (EU, 14 January 2010, online. Available http://ec.europa.eu/enlargement/ potential-candidates/bosnia_and_herzegovina/index_en.htm).

\section{References}

Andjelić, N. (1998) 'The Evolution of Civil Society in a Pre-war Bosnia-Herzegovina', in S. Bianchini and G. Schöpflin (eds) State Building in the Balkans. Dilemmas on the Eve of the 21st Century, Ravenna: Longo.

Belloni, R. (2001) 'Civil Society and Peacebuilding in Bosnia and Herzegovina', Journal of Peace Research, 38(2): 163-180.

Bianchini, S. (2000) 'Cultura politica e democratizzazione nei Balcani', in S. Matteucci (ed.) Il nazionalismo. Culture politiche, mediazione e conflitto, Ravenna: Longo.

Breuilly, J. (1999) 'Nationalism and Modernity', in J. U. Müller and B. Stråth (eds) Nationalism and Modernity, EUI Working Paper HEC No. 99/1, Florence: European University Institute. Online. Available http://cadmus.eui.eu/dspace/bitstream/1814/40/1/ HEC99-1.pdf (accessed 22 February 2010).

Centres for Civic Initiatives BiH (2006) 'Report about the Status of Citizens' Participation in Decision Making in BiH for 2006', online. Available HTTP: http://www.ccibh. org/dataf/CivicparticipationBiH2006.pdf (accessed 14 January 2008).

Cesareo, V. (ed.) (2003) I protagonisti della società civile, Soveria Mannelli: Rubbettino.

Chambers, S. (2002) 'A Critical Theory of Civil Society's in S. Chambers and W. Kymlicka (eds) Alternative Conceptions of Civil Society, Princeton, NJ: Princeton University Press.

Checkel, J. T. (2000) 'Compliance and Conditionality', ARENA Working Paper WP00/18. Online. Available www.arena.uio.no/publications/wp00_18.htm (accessed 15 November 2007).

— (2001) 'Social Construction and European Integration', in T. Christiansen, K. E. Jørgensen and A. Wiener (eds) The Social Construction of Europe, London: Sage.

Christiansen, T., Jørgensen, K. E. and Wiener, A. (eds) (2001) The Social Construction of Europe, London: Sage.

Cohen, J. L. and Arato, A. (1994) Civil Society and Political Theory, London: MIT Press.

Connor, W. (1995) Etnonazionalismo. Quando e perché emergono le nazioni, Bari: Dedalo.

Debiel, T. and Sticht, M. (2005) 'Towards a New Profile? Development, Humanitarian and Conflict Resolution NGOs in the Age of Globalization', Duisburg, Institute for Development and Peace, University Duisburg-Essen (INEF Report, 79/2005). Online. Available http://inef.uni-due.de/page/documents/Report79.pdf (accessed 27 November 2007).

Della Porta, D. and Caiani, M. (2006) Quale Europa? Europeizzazione, identità e conflitti, Bologna: Il Mulino.

Delli Zotti, G. (1991) 'La “rivoluzione” democratica nell'Est europeo', in G. Delli Zotti (ed.) Attori del mutamento nell'Est europeo, Milan: Angeli.

Eder, K. (2005) 'Remembering National Memories Together: The Formation of a Transnational Identity in Europe', in K. Eder and H. Kaelble (eds) Collective Memory and European Identity. The Effects of Integration on Enlargement, Aldershot: Ashgate.

Elbasani, A. (2008) The Stabilization and Association Process in the Balkans: Overloaded Agenda and Weak Incentives?, European University Institute, EUI Working Papers SPS 2008/03. Online. Available http://hdl.handle.net/1814/8447 (accessed 22 February 2010). 
European Commission (2000) 'The Commission and NGOs: Building a Stronger Partnership', Discussion Paper 18 January 2000, COM(2000)11. Online. Available http://ec. europa.eu/civil_society/ngo/docs/communication_en.pdf (accessed 2 October 2007).

(2003) 'EU-Western Balkans Summit - Declaration', Thessaloniki. Online. Available http://ec.europa.eu/enlargement/enlargement_process/accession_process/how_ does_a_country_join_the_eu/sap/thessaloniki_summit_en.htm (accessed 19 October 2007).

- (2006) 'Bosnia and Herzegovina 2006 Progress Report', SEC(2006) 1384 final, Brussels, 08.11.2006. Online. Available http://ec.europa.eu/enlargement/pdf/key_documents/2006/nov/bih_sec_1384_en.pdf (accessed 22 September 2007).

European Union (14 January 2010) 'Bosnia and Herzegovina - Country Profile', EU website. Online. Available http://ec.europa.eu/enlargement/potential-candidates/ bosnia_and_herzegovina/index_en.htm (accessed 21 February 2010).

Fischer, $\bar{M}$. (2006) 'Bosnia's Challenge: Economic Reform, Political Transformation and War-to-Peace Transition', in M. Fischer (ed.) Peacebuilding and Civil Society in Bosnia-Erzegovina. Ten Years after Dayton, Münster: Lit-Verlag.

Gellner, E. (1996) Le condizioni della libertà. La società civile e i suoi rivali, Milan: Edizioni di Comunità.

_ (1997) 'Società civile e contesto storico', in M. Magatti (ed.) Per la società civile. La centralità del 'principio sociale' nelle società avanzate, Milan: FrancoAngeli.

Herrmann, P. (1998) European Integration Between Institution Building and Social Process. Contributions to a Theory of Modernisation and NGOs in the Context of the Development of the EU, Commack, NY: Nova Science Publishers.

Jenkins, R. (2008) 'The Ambiguity of Europe: "Identity Crisis" or "Situation Normal”?', European Societies, 10(2): 153-176.

Kaldor, M. (1998) 'Transnational Civil Society', in S. Bianchini and G. Schöpflin (eds) State Building in the Balkans. Dilemmas on the Eve of the 21st Century, Ravenna: Longo.

Karajkov, R. (2005) 'The NGO Sector in the Balkans: Do We Need Reform?'. Online. Available www.oneworldsee.org/mk/node/6799 (accessed 10 February 2008).

— (2007) 'NGOs in the Balkans: Too Much of a Good Thing?', Newropeans Magazine. Online. Available www.newropeans-magazine.org/content/view/7313/259/ (accessed 10 February 2008).

Keane, J. (1988) Democracy and Civil Society, London and New York: Verso.

Kubik, J. (2005) 'How to Study Civil Society: The State of the Art and What to Do Next', East European Politics and Societies, 19(1): 105-120.

Manners, I. (2002) 'Normative Power Europe: a Contradiction in Terms?', Journal of Common Market Studies, 40(2): 235-258.

Mascia, M. (1991) L'associazionismo internazionale di promozione umana, Padua: Cedam.

Meister, A. (1971) Partecipazione sociale e cambiamento sociale. Materiali per una sociologia delle associazioni, Rome: Editrice AVE.

Melucci, A. (1991) 'L'azione volontaria tra società civile e sistema politico', in B. Tomai (ed.) Associazionismo, volontariato e nuova cittadinanza sociale, Milan: Cens.

Mungiu-Pippidi, A. (2006) 'East of Vienna, South of Drina. Explaining the Constituencies for Europe in South-Eastern Europe', in R. Rorschneider and S. Whitefield (eds) Public Opinion, Party Competition, and the European Union in Post-Communist Europe, Basingstoke: Palgrave Macmillan.

Nevola, G. (2007) Democrazia costituzione identità. Prospettive e limiti dell'integrazione europea, Padua: Liviana. 
OSCE (2003) 'Civil Society Policy', Mission to Bosnia and Herzegovina. Online. Available www.oscebih.org/documents/103-eng.pdf (accessed 3 March 2008).

_ (2004) 'Public Opinion Research - May 2004', Mission to Bosnia and Herzegovina. Online. Available www.oscebih.org/documents/741-eng.pdf (accessed 3 March 2008).

Radaelli, C. M. (2004) 'Europeanisation: Solution or Problem?', European Integration online Papers (EIoP), 8(16). Online. Available http://eiop.or.at/eiop/texte/2004-016a. htm (accessed 16 June 2008).

Raik, J. (2006) 'Promoting Democracy through Civil Society: How to Step up the EU's Policy towards the Eastern Neighbourhood', Centre for European Policy Studies, CEPS Working Document, 237/February 2006. Online. Available http://shop.ceps.eu/downfree.php?item id=1298 (accessed 2 April 2008).

Ranci, C. (1991) 'Azione volontaria e crisi del welfare', in B. Tomai (ed.) Associazionismo, volontariato e nuova cittadinanza sociale, Milan: Cens.

Reimann, K. D. (2006) 'A View from the Top: International Politics, Norms and the Worldwide Growth of NGOs', International Studies Quarterly, 50: 45-67.

Salamon, L. (1997) 'The Civil Society Sector', Society, 34(2): 60-66.

Sanchez-Salgado, R. (2006) 'Civil Society in Europe: Between Globalization and Europeanization', IEP-Paris, Joint Doctoral Seminar in International Relations 2006. Online. Available http://erg.politics.ox.ac.uk/projects/joint_doctoral_seminar/jds06_ sanchez-salgado_paper.pdf (accessed 21 May 2008).

Schöpflin, G. (1997) 'Civil Society, Ethnicity and the State: A Threefold Relationship', paper delivered at the conference 'Civil Society in Austria'. Online. Available www. ssees.ac.uk/gs1.htm (accessed 11 February 2007).

— (2000) 'Il futuro dell'Europa Centrale e Orientale: tre prospettive per il XX secolo', in S. Matteucci (ed.) Il nazionalismo. Culture politiche, mediazione e conflitto, Ravenna: Longo.

Sejfija, I. (2006) 'From the "Civil Sector" to Civil Society? Progress and Prospects', in M. Fischer (ed.) Peacebuilding and Civil Society in Bosnia-Erzegovina. Ten Years after Dayton, Münster: Lit-Verlag.

Seligman, A. B. (1992) The Idea of Civil Society, New York: Free Press.

— (2002) 'Civil Society as Idea and Ideal', in S. Chambers and W. Kymlicka (eds) Alternative Conceptions of Civil Society, Princeton, NJ: Princeton University Press.

USAID (United States Agency for International Development) (2007) 'The 2007 NGO Sustainability Index for Bosnia and Herzegovina'. Online. Available http://www.usaid. gov/locations/europe_eurasia/dem_gov/ngoindex/2007/bosnia_herzegovina.pdf (accessed 18 January 2008).

Walzer, M. (1997) 'L'idea di società civile', in M. Magatti (ed.) Per la società civile. La centralità del 'principio sociale' nelle società avanzate, Milan: Franco Angeli. 


\title{
6 European integration, cross- border cooperation and third sector mobilizations in the Basque Country $^{1}$
}

\author{
Xabier Itçaina
}

\section{Introduction}

The Basque Country constitutes an ideal site to observe the ambivalent effects of European integration at the local level, for three reasons. First, as a border zone, the Basque Country has been affected by changes in the regulation of the internal borders of the EU. Second, as the scene of the last violent ethno-nationalist conflict in Western Europe, Basque political and social actors still have to deal with a transnational identity which challenges the border itself. The Basque border has thus become the scene of a complex game between distinct (cultural, institutional and/or market-oriented) visions of cross-border cooperation. Third, civil society actors are strongly involved in cross-border relationships. This chapter investigates the role of third sector organizations in the increasing Basque crossborder mobilizations. To what extent do such mobilizations amount to an ongoing process of Europeanization? Europeanization refers to

\begin{abstract}
processes of (a) construction, (b) diffusion, and (c) institutionalization of formal and informal rules, procedures, policy paradigms, styles, 'ways of doing things', and shared beliefs and norms which are first defined and consolidated in the making of EU public policy and politics and then incorporated in the logic of domestic discourses, identities, political structures, and public policies.
\end{abstract}

(Radaelli 2003: 30)

Europeanization needs to be measured through sub-national units, as part of the domestic response to the EU (Murphy 2007). Broadly speaking, analysis of Europeanization at the sub-national level has to take into consideration the institutional impact of EU norms, as well as the Europeanization of organizations and institutions in terms of shared values and evolving attitudes towards the EU.

In order to adapt this line of questioning to cross-border relationships, one can refer to a distinction drawn by O'Dowd and McCall (2008), with reference to Ireland. Cross-border relationships are conceptualized in terms of two analytically distinct processes, one internationalizing, the other transnationalizing: 
The former is primarily 'border confirming', in that it involves interaction between organizations with territorial remits clearly demarcated by the state border and by their role within the panoply of state institutions. Such interaction has the effect of mutually recognizing and re-affirming the distinctive 'national state' basis of the organization involved.... Transnational relationships may be deemed to be 'border transcending', in that their approach to territoriality is more elastic as they generate networks or institutions formed to accomplish functional tasks across borders. They may involve both state and non-state organizations.

(O’Dowd and McCall 2008: 85)

In the light of this distinction, I argue in this chapter that the strong involvement of civil society and third sector organizations in the Basque cross-border collaborations fall within the transnational kind of relationships. Third sector refers here to an economic sector going beyond the mere non-profit sector, notably with the inclusion of all the 'organisations producing goods and services which are not constituted under the principle of the maximisation of profit' (Laville 2000: 4). ${ }^{2}$ Hence they have an ambivalent relationship to Europeanization. On the one hand, cross-border relationships between Basque third sector organizations are border-transcending. Basque identity-based mobilizations have used cross-border contacts in order to set up well-structured transnational networks, which aim to bypass the state-controlled design of institutional cooperation. Some of these civil society initiatives are linked to wider transnational social movements which could be seen as part of a process of 'Europeanisation from below' (Della Porta 2007). On the other hand, third sector mobilization maintains ambivalent relations - from partnership to competition - with cross-border cooperation policies that function on an interinstitutional basis. Therefore, these initiatives cannot be reduced to mere social movements which would only develop alternative initiatives. These transnational third sector mobilizations possess an instrumental, rather than identity-based, relationship to European integration. Europe, in this case, is regarded as an opportunity to go further in the institutionalization from below of a cross-border Basque common identity. As Reuter (2007) has argued concerning cross-border NGO cooperation in the Baltic Sea region, Basque third sector actors are developing a cross-border regional civil society, but this 'micro-regionalism' has to be understood in the light of the pursuit of different interests, going from local and/or nationalist conceptions to inclusion in a wider process of civil society transnationalization.

This chapter will develop this argument in three parts. First, such cross-border relationships are made possible only thanks to a particularly dynamic civil society and to third sector organizations located on each side of the border. Second, their initiatives take place in an evolving institutional context characterized by the increasing role of cross-border policies, which give an institutional dimension to already existing civil society cross-border networks. Third, the involvement of some third sector organizations in cross-border collaboration will 
illustrate this analysis, with two sectoral examples: mobilizations in favour of the Basque language and initiatives in favour of local economic development.

\section{An organized and dynamic civil society on both sides of the border}

Both the French and the Spanish Basque regions are well known for the dynamism of their respective civil societies. These dynamics have been analysed from different standpoints on each side of the border. In order to clarify the comparative framework, this first part aims to draw an analytical distinction between analysis focusing on civil society mobilizations and those focusing on third sector and social economy organizations.

\section{A 'society of movements'}

Several research projects have considered the dynamics of civil society, mostly in the Spanish Basque Country, through their relation to nationalist movements. Theories of resource mobilization were used to analyse the protest cycles closely associated with nationalist organizations, including those promoting political violence, such as ETA (Euskadi eta Askatasuna, Basque Homeland and Freedom), and other social movements. With the help of Tarrow's variables in the political structure, to which he adds the extent of consciousness-raising and the mobilization of civil society, Tejerina (2001) scrutinizes the protest cycle of ETA's violence from its origins at the beginning of the 1960s, through its consolidation in the 1970 s, to its decline from the mid-1980s onwards. The interactions set up between the armed organization, social movements and civil society proved to be crucial for understanding its vicissitudes. Many observers have emphasized the extraordinary level of protest in the Basque Country since the 1970s. Casquete (2006) has analysed the integrative function of protest for the group, by analysing Basque mass protests, conceptualized here as collective rituals. Protest rituals are seen here as a way of preserving group boundaries in order to face the generalized disapproval these groups may engender in wider society.

Civil society mobilizations are not monopolized by the nationalists. In reaction to the ethno-nationalist conflict, a pacifist third sector has developed in the Basque Country since the mid-1980s, with the aim of overcoming the binary nationalist/non-nationalist division and the potential threats to the process of conflict resolution. These threats include the persistence of a culture of violence at the local level, the central government's uncompromising positions, the influence of the international context and notably the war on terror since 9/11 (Conversi 2006). In such a context, activism within the peace movements proved to be a very delicate task as these movements gathered members from various political origins, from victims of terrorism to Basque nationalists. Mansvelt Beck (2005) distinguishes six groups acting for peace, founded between 1981 and 1999, and emphasizes the handicaps to their respective initiatives. Funes (1998) 
contrasts the strategies and support groups of the two main organizations, Gesto por la paz and Elkarri. Indeed the majority of Gesto members accepted the political regime after the transition, gathering a wide spectrum of political movements; Elkarri was closer to the nationalist left wing, though it rejected violence (Funes 1998: 508). Some organizations were concerned for the most part with the problem of compensation for the victims of ETA and excluded the Basque nationalist approach, while others stemmed from the critical factions within the Basque nationalist left wing. Mees highlights the fact that diverging opinions in the political sphere about the nature of the conflict may account for the differences among the peace movements (2003: 97). Contrary to Gesto por la paz, Elkarri considers that the debate is political, not ethical. The source of violence thus finds its origin in the opposition between a significant part of the population and the Spanish state on issues such as self-determination. Mees also points out that there is a risk in the openly political dimension of Elkarri's action, since its efficiency depends on the support of the parties. Third sector initiatives may also be criticized as constituting interventions of non-elected bodies. The Catholic Church has seemingly incorporated this spectrum of initiatives, thus finding itself in a delicate position within a fragmented pacifist movement, all the more so as most of these pacifist movements expected the Church to adopt a clear stance, as if they still saw the Catholic institution as a mediator par excellence (Itçaina 2010).

Recent research has also pointed out the emergence of new social movements in the Basque Country which are no longer directly linked to the ethnonationalist conflict. The Parte hartuz research team (University of the Basque Country) considers Basque society as a 'society of movements' in light of the increasing number of associations and organizations favouring alternatives to the current politico-economical system. Environmental protest in the Basque Country was first characterized by its close association with Basque nationalism (Barcena et al. 2003). Nevertheless, over a decade (1988-1997), environmental concerns became increasingly autonomous with regard to the national question, and became more embedded in the struggles of local communities to preserve their quality of life. The majority of ecological organizations, while they appear to have distanced themselves from the protest-oriented and anti-institutional scenario and discursive frame of radical Basque nationalism, have not embarked on a process of institutionalization. Instead, they seem to have found a new ecological space, 'eco-localism', from which to continue their work (Barcena et al. 2003). The mobilizations against the highway in the Leizaran and UrbinaMaltzaga valleys highlight the complex nature of the relationship between nationalism and environmentalism (Zubiaga Garate 2008). Many of today's pacifist movements borrow their repertoire of action - in terms of protest and mediation - from the environmental mobilization movements of the early 1990s, rather than from other classical socializing institutions such as the traditional Catholic Church (Zubiaga Garate 2008).

Neither the institutional context nor the socio-demographic reality of the French Basque Country gave birth to new social movements which would have 
been comparable to southern ones, with the exception of some recent environmental controversies. However, the debate about the institutionalization of the French Basque Country shed light on the dynamics emanating from very different milieux. Chaussier (1996) and Ahedo (2005) stressed the crucial role of civil society actors in the mobilization in favour of territorial institutionalization for the French Basque Country. Batera (Together) in 1999 aggregated four distinct demands: a separate department for the Basque Country; a co-official status for the Basque language; an autonomous Chamber of Agriculture for the Basque Country; and an autonomous university. These demands were endorsed by sectors of Basque society going far beyond the nationalist spectrum.

Some of these mobilizations, such as those in favour of the Basque language, are comparable to the Spanish Basque ones. Others are specific to French Basque civil society. More rural than the Spanish side, the French Basque region has been the scene of significant farmers' mobilizations since the mid-1970s. Collective action took the form of a specific trade unionism and a set of producers' initiatives in favour of a 'peasant and sustainable agriculture'. Such a mobilization was first supported by the ELB Union (Euskal Herriko Laborarien Sindikata, Union of the Farmers of the Basque Country), which constitutes the Basque branch of the French left-wing farmers' union Confédération Paysanne. Producers have also instigated many initiatives since the 1980s including quality and organic farming, and associations of transhumant shepherds. The ELB and producers' organizations alike asked for specific institutional representation for Basque agriculture, separate from the departmental official Chamber of Agriculture. The state administration and the Chamber of Agriculture of the PyrénéesAtlantiques repeatedly rejected such a demand in the name of the principle of 'one department, one chamber'. Supporters of an alternative chamber decided in January 2005 to found an associative Chamber of Agriculture for the Basque Country (Euskal Herriko Laborantxa Ganbara, EHLG) in the Lower Navarre. Its creation soon became highly controversial. Two legitimacies were at stake: state administration and the departmental chamber on one side, and supporters of farming and sustainable agriculture on the other. In this context, those standing for the alternative chamber tried to desectorialize their cause, by representing it not as the simple lobbying of farmers, but as an issue concerning all territorial actors, going far beyond the nationalist scope (Itçaina 2008).

\section{An organized civil society: third sector and social economy actors}

The literature cited above embraces a wide spectrum of actors. However, the focus is often on the more politicized mobilizations. To avoid this bias, the mobilization approach should be complemented by an organizational one, focused on third sector and social economy actors, as being more precise than civil society and more inclusive than the mere non-profit sector.

The social economy is flourishing on both sides of the border, despite legal differences. In the late 1990s, Euskadi and Navarra ranked first out of the seventeen Spanish Autonomous Communities in terms of social capital (Mota and 
Subirats 2000). In terms of interest and participation in public matters, the Basque Country ranked first out of the Spanish regions, followed by Navarra and La Rioja (Mota and Subirats 2000: 139). When considering associative networks, Mota and Subirats draw a distinction between economic and professional associations (private goods producers) on the one hand, and philanthropic and care-oriented associations (public goods producers) on the other. The more 'individualistic' Autonomies, where relations of coordination are predominant, were Madrid, Catalonia and Canarias. The more 'collectivist' ones were the Basque Country and Navarra. One has to remain attentive to the political implications of such high levels of social capital. The political contextualization allows a description of social capital as either positive (strong associative involvement and a sense of community) or negative (collective mistrust due to political divisions) (Ritaine 2001: 55). The Basco-Navarrese associative network originated in the period of Francoist repression and in the uncertainties of democratic transition. These caveats do not minimize the originality of a Basco-Navarrese associative network, which originated from and contributed to cohesive associative networks and mutual mistrust, maintaining solidarities and divisions.

Apart from the associations, the Basque Country is one of the leading regions in terms of cooperatives, together with Navarra, Andalusia and Valence. It owes this position to the cooperative complex of Mondragon, ${ }^{3}$ even if the Basque social economy as a whole cannot be reduced to this highly significant experience. Cooperatives ensured 47,975 jobs in the Basque Autonomous Community in 2004 (Gobierno Vasco 2007). Euskadi is also a leader in terms of sociedades laborales (12,974 jobs in 2004), an original entrepreneurial status located between the cooperative and the capitalist firm. In 2005 the Basque Autonomous Community ranked second behind Andalusia in terms of the aggregated number of workers in cooperatives and sociedades laborales. ${ }^{4}$ More recently, the Basque social economy started developing new forms of multi-stakeholder cooperatives associating public and private actors, and aimed at employing people systematically excluded from local labour markets and persons with mental, physical or social disabilities (Enciso Santocildes 2004).

For obvious demographic and historical reasons, the French Basque Country cannot be systematically compared to its neighbour. However, this territory also has a very specific profile as regards its social economy, thanks to associative and cooperative dynamics. From the mid-1970s, there was a burgeoning of associations in favour of the Basque language and culture. In the economic sector, a movement of workers' cooperatives emerged in the mid-1970s, and became representative of this territory at the national level. In the $1990 \mathrm{~s}-2000 \mathrm{~s}$, the dynamics of a social and solidarity-based economy intensified within this territory, albeit in different forms: cooperatives of service and small-sized industries, micro-finance, fair trade, social integration and local development. The French Basque Country ranked first in France in 2007 for its local micro-credit loan clubs for professional women (CLEFE, Local Club of Saving for Women Entrepreneurs). These dynamics were to be found in many sectors, particularly in agriculture, trade and services. 


\section{The ambivalent Europeanization of local cross-border policies}

Third sector initiatives take place in an evolving institutional context. On both sides of the border, public policies started experiencing a strong process of Europeanization or, more exactly, a mix between 'ex post communautisation' and 'ex ante Europeanisation' (Carter and Pasquier 2006) ${ }^{5}$ through the development of cross-border operations from the late 1980s. As a result, an institutional design favourable to cross-border collaboration was set up in the Basque Country, which attracted third sector actors. This context of Europeanization was perceived as both an opportunity and a constraint by Basque nationalists. Increasing cross-border relations also brought to light the institutional asymmetry between the two sides of the border.

\section{A new institutional design in favour of cross-border collaboration}

The Europeanization process can be perceived first through its institutional dimensions. In his research devoted to the implementation of the INTERREG III-A France-Spain programme, Harguindéguy defines cross-border cooperation as 'all types of negotiated actions between the public institutions of at least two neighbouring countries’ (2007: 317). Ten years earlier, Letamendia (1997) had emphasized the importance of the process of European integration as a factor encouraging cross-border cooperation in the Basque Country. According to him, European integration manifested two very different trends. On the one hand, control over the French-Spanish border was reinforced due to EU anti-terrorism and immigration policies. On the other hand, European integration encouraged a cooperative framework hitherto reserved to the nation-state because it fell within the scope of international relations.

From 1983, the Aquitaine and the Basque Autonomous Community took part, together with the other seven border regions, in the Working Community of the Pyrenees. New programmes of cooperation appeared when Spain joined the Common Market in 1986. They were supported not only by civil society actors, but also by public authorities. The cooperation between the Basque Autonomous Community and the Aquitaine region enjoyed a major boost from 1989, 'coinciding with the Structural Funds Reform and the impulse given by the Single European Act to the Union's regional policy' (Letamendia 1997: 36). Identitybased cooperation was relayed through institutional cooperation, the latter being stimulated by European funds such as the INTERREG programmes from 1990. In the Basque Country, INTERREG funds, while reinforcing cross-border relations, renewed a strong tradition of collaboration between local authorities and civil society actors at the border. Several cooperative programmes were set up. Among others, the Aquitaine-Euskadi association, ${ }^{6}$ created in 1989, started a common fund in the domains of research, socio-economic development and training. The Bayonne-San Sebastián Eurocity, which started in 1995, strengthened cooperation on urban planning between the two urban areas. In the border 


\section{$114 X$. Itçaina}

zone, the Eurodistrict Bidasoa-Txingudi (established in 1992) and the Consorcio Bidasoa-Txingudi (1998) brought together in one inter-city structure the French city of Hendaye and the Spanish cities of Fontarrabie and Irun. The Txingudi experience was seen as a successful example of inter-institutional collaboration when compared to other Pyrenean experiences (Harguindéguy 2007). The Treaty of Bayonne, signed between France and Spain in 1995, reinforced this legal framework by giving more latitude to the local authorities in terms of crossborder collaboration. These new institutional opportunities did not necessarily provoke an increase in the diffusion of ethnonationalism (Mansvelt Beck 2008) but they created a new institutional climate favouring the development of crossborder exchanges on a more regular basis.

\section{The EU as a resource and/or a constraint for Basque nationalists}

Such instruments of cross-border collaboration were likely to be promoted by Basque nationalists in order to strengthen the nation-building process. In particular, cross-border collaboration completed the international strategy of the government of Euskadi. Totoricagüena (2005) has emphasized how the Basque government has mobilized the Basque diaspora all over the world, and especially in Latin and North America, in order to elaborate a 'paradiplomacy' aimed at bypassing the Spanish state. ${ }^{7}$

The relation of the Basque nationalist parties and movements to the EU and to European integration is more complex and goes far beyond the single political instrumentalization of EU programmes. Drawing evidence from minority nationalist parties in Wales and in Galicia, Elias has argued that 'whilst minority nationalist parties may not have turned their back completely on the idea of a Europe of the Regions, a new pragmatism drives theses parties' strategies and tactics for meeting their short- and long-term goals' (2008: 557). Minority nationalist parties will assume one of four possible positions on European integration (Elias 2008: 562). First, Euro-enthusiast parties will combine support in principle for Europe as a framework for enhancing national autonomy. They evaluate positively the economic, political and cultural opportunities for the minority nation within the EU as it currently exists. Second, those who reject Europe will reject the notion that European integration can provide a long-term solution to the territorial autonomy question, and will be highly critical of the concrete institutional and political realities of the EU. Third, Euro-sceptic parties will accept that European integration may provide new solutions for reorganizing territorial authority in the long term, but will perceive the EU as it has developed in practice to be unsatisfactory. Fourth, Euro-pragmatists will support the EU on the basis of pragmatic or utilitarian considerations, since doing so means satisfying specific policy demands. However, such parties will reject the basic principles underlying the integration process, and will not recognize the long-term potential of European integration to meet core nationalist demands.

Taken as a whole, Basque nationalists have evolved from a very proEuropean attitude towards a more qualified one. However, distinctions should be 
made according to different nationalist leanings, particularly in the Spanish Basque region where nationalism is stronger. Basque radical nationalists close to Batasuna could be seen at first glance as highly critical of the policy realities of the EU. The EU was perceived first as a Europe of states, then as an economically liberal and socially regressive project. Nevertheless, radical nationalists frequently used European institutional arenas (particularly the European Parliament and the European Court of Human Rights) in their strategy of internationalization of the Basque conflict, against the Spanish state. The EU's involvement in the Irish peace process was also invoked as a precedent by Basque nationalists. This strategy had certain results, as on 13 December 2007 when the European Court of Human Rights declared partly admissible the claim of Batasuna against the Spanish government concerning the banning of parties and electoral lists within the left-wing Basque pro-independence movement since 2003 on the grounds that it had failed to condemn the ETA killings and maintained alleged ties with the violent perpetrators. However, in June 2009, the Strasbourg Court finally confirmed the ruling by the Spanish Supreme and Constitutional Courts banning Batasuna. ${ }^{8}$ Batasuna and, in December 2008, Acción Nacionalista Vasca and Partido Comunista de las Tierras Vascas, parties belonging to radical leftwing Basque nationalism, were also included in the EU list of terrorist persons and organizations, together with ETA and its circle of supporters. ${ }^{9}$

Moderate nationalists, on the other hand (PNV, Eusko Alkartasuna, Aralar, Abertzalen batasuna), which had been Euro-enthusiast were becoming more Euro-pragmatist. The Spanish Basque and Catalan autonomies tried to use the political and institutional resources of European integration in order to distance themselves from the Spanish central state (Ithurralde 2002). The strong involvement of the autonomous government in cross-border cooperation was one feature of this strategy. Nevertheless, moderate nationalists realized that the EU could be instrumentalized in order to reinforce the central state. Ithurralde (2002: 262) and Bourne (2002) have analysed several disputes between EU and Spanish Basque authorities over the permissible scope of Basque taxation prerogatives. In these episodes, the EU's market competition imperative provided a justification for the depreciation of historically and politically significant Basque taxation competencies and there were more obstacles than opportunities for forming influential strategic alliances with EU authorities (Bourne 2002).

\section{Institutional asymmetry as an obstacle to cross-border relations?}

Nevertheless, the EU offered new opportunities for developing cross-border relations between Basques. These programmes implied that collaboration should be developed between equivalent institutional entities: the counterpart of the Basque Autonomous Community in Spain was not the French Basque Country, which had no institutional representation before the mid-1990s, but the French region of Aquitaine. Letamendia (1997: 36) has stressed the gap in cooperation between equivalent institutional bodies, and the collaboration between Basques acting on the basis of a common identity. Institutional relations between Euskadi and the 
Aquitaine region were also marked by an institutional asymmetry, since the budget of the Basque Autonomous Community was more than ten times greater than that of any French region. A gap also existed between the perception of interregional cooperation in a Regional Council of Aquitaine controlled by right- or left-wing French parties, and an Autonomous Basque Community controlled by moderate Basque nationalists supporting a strategy in accordance with which European integration should make nation-states redundant (Letamendia 1997: 37).

According to Letamendia, cross-border collaboration became an element for exercising pressure in favour of the institutionalization of the French Basque Country. Things changed with the partial institutionalization of the French Basque Country in the mid-1990s, when a Basque Country Development Council and a Council for Elected Representatives were set up in 1994 and 1995, respectively. These councils were conceived as new debating loci for elected officials and civil society representatives and as a compromise between nationalists, civil society actors and public authorities:

although for the time being the reality of the Département of PyrénéesAtlantiques will not be questioned, a process will be initiated to proceed to a sort of 'private' institutionalization of its Basque territories ... This goes in the opposite direction of the general trend of French decentralization, which gives pre-eminence to those who are elected.

(Letamendia 1997: 39)

For the first time in the last thirty years, a convergence was seen between the sphere of civil society inspired by Northern Basque nationalism as a whole, and the cross-border initiatives coming from the moderate and institutional Southern Basque nationalism (Letamendia 1997: 38).

Letamendia's position should be qualified in light of the socio-political evolution of the French Basque Country over the last ten years. First, the Pays Basque did not go in the opposite direction to French decentralization. On the contrary, the Basque experience was seen as a virtuous example of local development, and inspired the national policy of the pays. Second, the territorial institutionalization of the French Basque Country, far from being controlled or inspired by Basque nationalists, was rather the result of a permanent compromise between different political tendencies (French right and centre-right, socialist, Green, Basque moderate nationalist) and socio-economic milieux. Third, the process of the institutionalization of the French Basque Country cannot be considered as a mere 'private type of institutionalization' or as compensation for the refusal to found a Basque department. Over the last ten years, new French Basque territorial institutions have had tangible effects on territorial governance. Expert work conducted by the Development Council has resulted in concrete measures, such as territorial contracts involving the state, the Regional Council of Aquitaine, the General Council of the Pyrénées-Atlantiques and local authorities. Fourth, in such a context, it is not crucial to find out whether cross-border collaboration has become a real factor in institutional change in the Northern Basque Country. It is 
crucial, rather, to evaluate the terms by which the new territorial institutionalization of the French Basque Country has come to influence cross-border collaboration. Cross-border collaboration ranked among the three priorities of the Basque Country Development Council in its Pays Basque 2020 prospective programme, together with territorial reciprocity (between the coastal zone and the inland countryside) and sustainable development.

To sum up, the recent intensification of a cross-border policy in the Basque Country presents three characteristics. First, cross-border cooperation is not monopolized by Basque nationalist parties and movements, but rather is invested in by heterogeneous coalitions of actors. Second, and despite critical voices emanating from radical nationalists, the institutionalization process of the French Basque Country from the mid-1990s onwards reinforced cross-border collaboration. Finally, the instrumental Europeanization of public policies did not automatically lead to the Europeanization of shared norms and cultural values. Relying on her fieldwork in Txingudi, Bray (2006) emphasizes that even if a 'trans-frontier Basque public sphere' is being set up, with more and more people living on one side of the border and working on the other, there is "no clear sign of this emerging cross-frontier reality extending to a stronger identification with Europe' (Bray 2006: 540).

\section{Third sector cross-border relations and Basque identity}

The cross-border relationships between private companies and between public authorities are relatively well known, as well as the cross-border strategies implemented by political parties and trade unions. This is far from the case for initiatives coming from the third sector. Yet such initiatives deserve special attention for three reasons. First, cross-border third sector mobilizations contribute to the consolidation of a transnational Basque identity in an original way, bypassing statecontrolled policies and Basque nationalist political apparatus. Bray is right when expressing doubts about 'the usage of the term ethnonational for describing all grassroot political mobilizations in places like the Basque Country' (Bray 2006: 534). Second, the strength of these mobilizations comes from the ability of third sector actors to draw on support from wider transnational networks. This allows them to make a connection between the Basque cause and wider transversal issues, such as the environment, sustainable agriculture and rural development or minority languages. Third, the relationship between these initiatives and local public authorities has evolved. Most of the cross-border initiatives experienced a partial institutionalization when being integrated into emerging cross-border policy networks. Examples will be taken here from two sectors: mobilizations in favour of the Basque language and economic mobilizations.

\section{Third sector and cross-border linguistic mobilizations}

The core symbolic and functional role of language in the Basque collective identity has given special relevance to those third sector mobilizations in favour of 
euskera (the Basque language). A survey conducted in the mid-1990s among the projects funded by the Aquitaine-Euskadi Common Fund showed evidence that among economic, cultural and university-based projects, the cultural ones were those which attracted more actors from Euskadi and, in Aquitaine, from the French Basque Country (Itçaina et al. 1997). Partners from Aquitaine, and notably from Bordeaux, were involved in more research and economic projects. The importance of culture was directly linked to the shared Basque identity and language. However, several projects met with difficulties in their implementation, because of the institutional asymmetry between the two partners. Several projects related to Basque culture were endorsed by the Southern public institutions, whereas their French Basque counterparts were often associations. Identity, which had given an impetus to cross-border cooperation, was confronted with the institutional gap between third sector actors on the one hand and public institutions on the other.

These findings should probably be revised in 2009, for two reasons. First, the promotion of the Basque language was partly institutionalized in the French Basque Country with the foundation of the Council for the Basque Language in 2001, which in 2005 became the Public Office for the Basque Language. Thus, the promotion of euskera was no longer exclusively for the benefit of associative activists. It soon became a sector of public policy in its own right. Until then, mediation between the associative third sector and public authorities concerning Basque cultural matters was conducted by the Basque Cultural Institute (Institut Culturel Basque, ICB). The foundation of an autonomous linguistic policy induced a formal distinction between linguistic and cultural policies, which had been more or less combined until then, except as regards bilingual schools ${ }^{10}$ and Basque lessons for adults.

The recent institutionalization of a linguistic policy in the French Basque Country had consequences for cross-border relationships. Until then, crossborder linguistic relations could be seen as support coming from the South to the North. Such support took two forms: transnational associative networks, organized on a Basque 'national' basis; and institutional support from Southern public bodies towards Northern associations. Amado Borthayre (2006) makes a distinction between cross-border associative networks of interest groups aimed at changing public policies (Euskal Herrian Euskaraz, Kontseilua-Euskal konfederazioa $)^{11}$ and alternative socio-linguistic mobilizations. Far from limiting themselves to lobbying, the latter considered themselves as constituting educational and social alternatives. Significant examples are the associative schools (ikastola), the association providing Basque lessons for adults, AEK, ${ }^{12}$ and the Basque Summer School (Udako Euskal Unibertsitatea). All of these experiences, and especially the alternative-oriented ones, share four characteristics. First, they have a transnational structure and engage in transnational activities. Second, their internal organization is based on democratic principles: collective decisionmaking and horizontal power relations. Third, many of these initiatives depend on Southern Basque financial resources (which reproduces at civil society level the institutional asymmetry). Fourth, Europe is used as a tool for enhancing 
cross-border collaboration and for the promotion of euskera, notably via the European Bureau for Lesser Used Languages.

The relationship between linguistic cross-border mobilizations and public authorities has taken at least two forms. On the one hand, cross-border social movements enhanced those public policies favouring the Basque language in the French Basque region. First, the Southern Autonomous government, controlled by the PNV until 2009, intervened in the French Basque Country from the 1990s, through subsidies to the educational network and to Basque-speaking media. Such sub-state governmental intervention, beyond its jurisdiction, was coupled with initiatives coming from cross-border associations of local municipalities (Udalbide and Udalbiltza). Second, new public policies were set up jointly by public institutions from both sides of the border. The foundation of a cross-border radio station (Antxeta irratia) in Txingudi illustrates this point. In the same vein, sociolinguistic surveys were conducted on both sides of the border from 1996 by the Basque government, in association with Navarrese and French Basque bodies. The installation of the Public Office for the Basque Language in 2005 in the French Basque region intensified the cooperation between public authorities. The Southern regional government had its institutional, even if not equivalent, counterpart in the North.

On the other hand, this process of institutionalization, however partial, generated internal controversies within the social movements. When the Basque autonomous government set up a new service (HABE) for the teaching Basque language to adults in 1981, this was perceived as a challenge by the AEK, before an agreement was reached in 1994. The AEK was then recognized as an agency of general interest in favour of the Basque language. In France, the AEK benefited from gaining the first official recognition as a vocational training body through the Specific Agreement for the Development of the French Basque Country between the state, the Aquitaine Region and the Pyrénées-Atlantiques department, signed in 2000. In the same vein, official recognition of the ikastola following an agreement with the French Ministry of Education in 1992 generated debates between the supporters of such institutionalization and those giving priority to the social movement dimension of the ikastola (Bortayrou et al. 2005).

\section{Third sector and cross-border economic cooperation}

At first glance, the identity dimension of cross-border relations is less obvious in the case of economic mobilizations. Nevertheless, several socio-economic organizations have been very active in cross-border relations, as illustrated here by the workers' cooperatives and the farmers' mobilization. Socio-economic and, more precisely here, social economy organizations seized upon the new opportunities offered by Europe to develop new transnational relations. These programmes gave an institutional frame to an existing set of relations between the cooperative movements on both sides of the frontier. The French Basque workers' cooperative had been directly inspired, in the 1970 s, by the seminal 
experience of Mondragón. In the 1990s-2000s, cross-border relations between French and Spanish Basque cooperatives were given a new impetus thanks to the new institutional design. Members of the French Basque cooperative movement took full advantage of such new possibilities, beyond simply commercial relations. The Hezkuntek association, ${ }^{13}$ whose objective is to promote the enrolment of young French Basques in Spanish Basque secondary schools for vocational training, offers an excellent illustration of the symbolic relations that can exist between a common Basque identity, cooperative values, economic development and transborder cooperation. Hezkuntek's aim is 'to further industrial development in Labourd, Basse-Navarre and Soule through the promotion of technical and vocational training in the Basque-speaking population' (Statutes of Hezkuntek). The main idea was to promote professional training in the Basque language, which was a way of showing the economic relevance of minority languages and of improving the image of vocational training. The programme was supported by the manager of a workers' cooperative on the French side, and by institutions that belonged to the Mondragón network in Spain. In 2003 Hezkuntek received financial support from Udalbiltza and in March 2006 it signed an agreement with the Ministry of Education of the Basque Autonomous government, in order to facilitate access to vocational training in Euskadi for French Basque-speaking students. Hezkuntek can thus be seen as a by-product of two complementary associations whose legitimacy rests on shared cultural references, and is a good example of structuring partnerships between public semipublic, and cooperative and associative bodies.

In a more direct way, European programmes also helped to reinforce crossborder links and eventually the cooperative movement itself. The ARIPTIC project, for instance, groups the Arizmendi Koop and the Institut Supérieure de Formation Permanente (INSUP). Arizmendi Koop, a Mondragón cooperative, promotes education and training programmes through a network of schools, with an emphasis on teaching in the Basque language. It is particularly active in cultural and social domains. INSUP, a training body in Aquitaine, has developed its activities since 1980 in the field of integration programmes for young people who want to go back to work. Both bodies had already been partners in a series of projects financed by INTERREG or the Aquitaine-Euskadi Common Fund, which led to the creation of a European Economic Interest grouping in March 2002, the first step towards a European Cooperative Society. The way ARINSUP has used INTERREG III (2000-2006) funding shows its desire to adopt a balanced linguistic and cultural approach, such as e-learning programmes and providing courses in Basque, French and Spanish, together with secretarial and accountancy lessons. EU policies have thus provided the opportunity for crossborder actors from distinct institutional and social backgrounds to institutionalize their relationships.

The French Basque movement in favour of sustainable farming and specific territorial institutionalization for Basque agriculture also benefited from great support from the transnational 'Basque social movement industry'. The alternative Chamber of Agriculture (EHLG), set up in 2005, was assisted by logistical 
and financial resources from the Spanish Basque region. This was a way to compensate it for the lack of public resources from the French side. As a non-profitmaking body (association in French), EHLG could not benefit from the para-fiscal taxes paid by farmers, which are the basic finances of the official Chambers of Agriculture. Moreover, local authority subsidies were allegedly illegal. The lack of resources motivated the promoters of EHLG to look for individual and collective donors. Thanks to the contribution of the Manu Robles Arangiz Foundation, created by the moderate Basque nationalist union ELA, EHLG could purchase and renovate its headquarters. EHLG could also take advantage of institutional support from the Southern regional government. On 2 November 2007, on the occasion of the agricultural fair Lurrama, EHLG signed agreements with the cross-border association of local councillors Udalbide and with Itsasmendikoia, a public agency for rural development linked to the Basque Autonomous government. Of a total budget of 410,000 euros for EHLG in 2007, 41 per cent came from French Basque donors, 27 per cent were proper receipts, 26 per cent came from Itsasmendikoia and Udalbide, and 3.9 per cent came from Spanish Basque donors (Euskal Herriko Laborantza Ganbara 2008).

This new cross-border impetus was the continuation of an older partnership between French and Spanish Basque farmers' unions: ELB on the French side and EHNE (Euskal Herriko Nekezarien Elkartasuna, Union of Farmers from the Basque Country) on the Spanish side. They have both been active members (via the European Confédération Paysanne) of the international peasant movement Via Campesina. In 2008, EHNE leader Paul Nicholson was one of the two representatives for Europe of Via Campesina. Transnational support gave rise to cross-border projects such as the publication of a trilingual guide to the Basque countryside and a comparative study on agriculture in the French Basque Country, the Spanish Basque Autonomous Community and Navarra.

In January 2009, on the eve of the legal proceedings started by the French state against EHLG, the Spanish Basque government made official a new partnership with the SUAT Pays Basque, a branch of the official departmental Chamber of Agriculture (Taberna 2009). This partnership focused on the development of cross-border training programmes, thanks to European funds among others. Such an agreement was evidence of a strategy of institutional isomorphism, or mutual recognition between institutions, between the Basque government and the official Chamber of Agriculture. On the very sensitive issue of agriculture, the Basque government was careful not to be seen to be interfering in French - even if Basque - affairs. Ideological proximity (between Southern Basque nationalists and Northern supporters of EHLG) had thus to be reconciled with institutional proximity (between the official Chamber of Agriculture of the Pyrénées-Atlantiques and the Basque autonomous government).

Both cases (social economy and farmers' movement) show that the economic and cultural spheres are deeply interconnected. Thus, the opinion stating that, in the Basque borderland, the economic and infrastructural content of cross-border cooperation has operated to the detriment of an identity or cultural content (Mansvelt Beck 2008: 380) should be qualified. This might be true of some of 
the 'top-down' institutional cross-border initiatives. It has not necessarily been the case for the cross-border economic mobilizations emerging from the third sector and experiencing a partial process of institutionalization. Even if the above-mentioned experiences remain marginal for the territorial economies, they constitute highly significant cases of hybridization of resources (public, private, associative) and ideas (local development and cultural identity).

\section{Conclusion}

These two examples (linguistic and socio-economic mobilizations) illustrate how the third sector's cross-border initiatives are part of a transnational and bordertranscending relationship aimed at bypassing the state-controlled design of institutional cooperation. Such initiatives fuel an ambiguous relationship with Europeanization. Indeed, third sector mobilizations convey an instrumental, rather than identity-based, relationship to Europe. At the same time, every crossborder mobilization tries to include its cause within wider transnational mobilizations at the European and international level (social economy, farmers' movement, promotion of minority languages) in order to gain international support. Such a complex relationship between local issues and international causes, civil society actors and multi-level institutional frames, requires further research, notably from a comparative perspective, on other border-transcending dynamics.

\section{Notes}

1 I am grateful to the members of the GARNET Jointly Executed Research Programme 'Civil Society and Non State Actors', and specially to Julie Gilson for her comments and decisive help in English language editing, and to Andy Smith and Cathal McCall for their comments. The seven historical Basque provinces fall within the Basque Autonomous Community (Euskadi), the Foral Community of Navarra in Spain and the western part of the Pyrénées-Atlantiques département in France.

2 Salamon and Anheier (1995) include in the non-profit sector organizations presenting a formal constitution, a legally private status, a form of self-government, nonredistribution of profits and the participation of volunteers. This approach was considered to be too restrictive by supporters of the social and solidarity-based economy (Laville 2000). The condition of volunteering may exclude sectors of the traditional social economy, such as workers' cooperatives and mutuals, which can redistribute benefits to their members in a limited way. Few countries use the American term 'non-profit sector' to describe the set of organizations located between the private, for-profit and public sectors. For comparative purposes, 'it seems useful to adopt the term "third sector" to designate all organizations which are neither profit-oriented businesses nor governmental agencies or bureaucracies' (Seibel and Anheier 1990: 7). Some authors reject the expression 'third sector', considering that social economy organizations, far from constituting a separate sector, are part of the private sector while fulfilling general interest aims (Peyre 2004). The Spanish CIRIEC makes a distinction within the social economy between (a) the market-oriented sector, including democratically organized private businesses, and (b) the non-market-oriented sector including private non-profit institutions developing activities of services. See www. observatorioeconomiasocial.es. 
3 Located in Guipuzcoa, the cooperative consortium of Mondragón (MCC) is organized along four poles: financial, industrial, distributional and corporative. In December 2007, MCC represented 103,731 jobs all over the world. Mondragón is based on ten principles: freedom of membership, democratic organization, sovereignty of labour over capital, participative management, limited scale of wages, inter-cooperation, social transformation, universality and education.

4 CIREC, Cooperativas y Sociedades Laborales: Número de empresas y trabajadores en situación de alta en la Seguridad Social. Distribución por Comunidades Autónomas a 31/12/05, Observatorio de la Economía Social, 2005.

5 Carter and Pasquier (2006) suggest a need to distinguish, at the regional level, between 'ex post Communautisation' (the process by which domestic laws and rules are aligned to EU requirements in the implementation of Community laws and rules) and ex ante Europeanization (the phase of the policy cycle when domestic policies are up-loaded to the European level for negotiation).

6 Navarra took part in this common fund before withdrawing due to disagreements with the Basque government. Therefore, Aquitaine has separate agreements with Euskadi, Navarra and Aragon.

7 Most of this chapter was written before the 1 March 2009 elections for the Basque Parliament, which led to the first non-Basque nationalist autonomous government since 1980.

8 'El Tribunal de Estrasburgo ratifica la ilegalización de Batasuna', El País, 30 June 2009.

9 'L'Union européenne ajoute deux partis basques à sa liste terroriste', Le VifL'Express, 16 December 2008.

10 In France, the Basque language is taught in three educational networks: Ikastola associative total immersion schools, public (Ikasbi) and Catholic (Euskal haziak) bilingual schools.

11 'Speaking Basque in the Basque Country', 'the Council - the Basque confederation'.

12 AEK (Alfabetatze Euskalduntze Koordinakundea: Coordination for literacy in euskera) is also the organizer, every two years, of Korrika, a symbolic race run in one-kilometre relays in favour of the teaching of the Basque language to adults. Del Valle (1994) looks at the emergence of Korrika as a modern ritual for expressing Basque identity. This race also implies a symbolic negation of the border.

13 Neologism, from hezkuntza (training) and teknikoa (technical).

\section{References}

Ahedo, I. (2005) 'Nationalism in the French Basque Country', Regional and Federal Studies, March, 15(1): 75-91.

Ahedo, I., Etxebarria, N. and Letamendia, F. (2004) Redes transfronterizas intervascas, Bilbao: UPV-EHU.

Amado Borthayre, L. (2006) 'Los movimientos sociales "nacionales” de la lengua, ¿Creadores de políticas públicas "nacionales” vascas?', in F. Letamendia (ed.) Acción colectiva Hegoalde-Iparralde, Madrid: Editorial Fundamentos: 285-316.

Barcena, I., Ibarra, P., Guarrotxena, E. and Torre, J. (2003) 'The Basque Country', in C. Rootes (ed.) Environmental Protest in Western Europe, Oxford: Oxford University Press: 200-16.

Beck, J. M. (2005) Territory and Terror. Conflicting Nationalisms in the Basque Country, London and New York: Routledge.

Bortayrou, J., Etcheverry-Ainchart, P., Garat, M. and Leralu, C. (2005) Le Mouvement culturel basque. 1951-2001. T. 2: Filières bilingues, Seaska, AEK, Bayonne: Elkar.

Bourne, A. K. (2002) 'Defending Basque Taxation Devolution in the European Union: 


\section{X. Itçaina}

The Price of European Integration', International Journal of Iberian Studies, 15(2): $103-11$.

_ (2003) 'European Integration and Conflict Resolution in the Basque Country, Northern Ireland and Cyprus', Perspectives on European Politics and Society, 4(3): 391-415.

Bray, Z. (2004) Living Boundaries. Frontiers and Identity in the Basque Country, Brussels: P.I.E. Peter Lang.

- (2006) 'Basque Militant Youth in France: New Experiences of Ethnonational Identity in the European Context', Nationalism and Ethnic Politics, 15: 533-53.

Carter, C. and Pasquier, R. (2006) 'European Integration and the Transformation of Regional Governance: Testing the Analytical Purchase of Europeanisation', Queen's Papers on Europeanisation, No. 1. Online. Available www.qub.ac.uk/schools/SchoolofPoliticsInternationalStudiesandPhilosophy/FileStore/EuropeanisationFiles/ Filetoupload,38451,en.pdf (accessed 22 February 2010).

Casquete, J. (2006) 'The Power of Demonstrations', Social Movement Studies, 5(1): 45-60.

Chaussier, J.-D. (1996) Quel territoire pour le Pays Basque? Les cartes de l'identité, Paris: L'Harmattan.

Conversi, D. (2006) 'Why Do Peace Processes Collapse? The Basque Conflict and the Three-Spoilers Perspective', in E. Newman and O. Richmond (eds) Challenges to Peacebuilding: Managing Spoilers During Conflict Resolution, Tokyo: United Nations University Press: 173-99.

Del Valle, T. (1994) Korrika. Basque Ritual for Ethnic Identity, Reno: University of Nevada Press.

Della Porta, D. (2007) 'Europeanisation from Below? Social Movements and Europe', Mobilization: An International Quarterly, 12(1): 1-20.

Elias, A. (2008) 'From Euro-enthusiasm to Euro-scepticism? A Re-evaluation of Minority Nationalist Party Attitudes towards European Integration', Regional and Federal Studies, 18(5): 557-81.

Enciso Santocildes, M. (2004) 'Las cooperativas de iniciativa social', Anuario de Estudios Cooperativos, Kooperatiba Ikaskuntzen Urtekaria, Universidad de Deusto: Bilbao: 160-3.

Euskal Herriko Laborantza Ganbara (2008) 'Trois ans, 14/01/2005-19/01/2008', Euskal Herriko Laborantza Ganbara's internal document, 19 January.

Funes, M. J. (1998) 'Social Responses to Political Violence in the Basque Country: Peace Movements and their Audience', The Journal of Conflict Resolution, 42(4): 493-510.

Gobierno Vasco (2007) Estadística de la economía social vasca, Departamento de Justicia, Empleo y Seguridad social del Gobierno Basco.

Harguindéguy, J.-B. (2005) 'L'Europe par les frontières: la mise en œuvre de l'initiative communautaire INTERREG III A en faveur de la coopération transfrontalière francoespagnole', unpublished thesis, Florence: IUE.

— (2007) 'Cross-border policy in Europe. Implementing INTERREG III-A FranceSpain', Regional and Federal Studies, 17(3): 317-34.

Itçaina, X. (2008) 'Un ordre institutionnel local en mutation? Autour des développements récents de la "question agricole" en Pays Basque', Les Cahiers du CEVIPOF, 48: 91-111.

_ (2010) 'Between Mediation and Commitment. The Catholic Church and the Basque Conflict', in J. Haynes (ed.) Religion and Politics in Europe, the Middle East and North Africa. Challenges to Citizenship, Secularisation and Democracy, London and New York: Routledge: 91-113.

Itçaina, X., Palard, J. and Vignes, B. (1997) 'Politique institutionnelle ou mobilisation sociale? Le Fonds commun Aquitaine-Euskadi', in J. Palard (ed.) L'Europe aux frontières, Paris: PUF-GRALE: 131-54. 
Ithurralde, M.-A. (2002) Le Pays Basque, la Catalogne et l'Europe. Stratégies politiques des Autonomies basque et catalane, Paris: L'Harmattan.

Laville, J.-L. (2000) L'Économie sociale et solidaire en Europe, Paris: CRIDA, Les Notes de l'Institut Karl Polanyi. Online. Available www.karlpolanyi.org/02_les\%20notes/ pdf/06entreprise.pdf (accessed 22 February 2010).

Letamendia, F. (1997) 'Basque Nationalism and Cross-Border Co-operation between the Southern and Northern Basque Countries', Regional and Federal Studies, 17(2): 25-41.

— (ed.) (2006) Acción colectiva Hegoalde-Iparralde, Madrid: Editorial Fundamentos.

Mansvelt Beck, J. (2005) Territory and Terror. Conflicting Nationalisms in the Basque Country, London: Routledge.

_ (2008) 'Has the Basque Borderland Become More Basque after Opening the Franco-Spanish Border?', National Identities, 10(4): 373-88.

Mees, L. (2003) Nationalism, Violence and Democracy. The Basque Clash of Identities, Houndmills and New York: Palgrave Macmillan.

Mota, F. and Subirats, J. (2000) 'El quinto elemento: el capital social de las Comunidades Autónomas. Su impacto sobre el funcionamiento del sistema político autonómico', Revista Española de Ciencia Política, 1(2): 123-58.

Murphy, M. C. (2007) 'Europeanisation and the Sub-national Level: Changing Patterns of Governance in Northern Ireland', Regional and Federal Studies, 17(3): 293-315.

O'Dowd, L. and McCall, C. (2008) 'Escaping the Cage of Ethno-national Conflict in Northern Ireland? The Importance of Transnational Networks', Ethnopolitics, 7(1): 81-99.

Peyre, R. (2004) 'Si l'économie sociale nous était comptée?' in X. Itçaina, R. Lafore and C. Sorbets (eds) Un monde en quête de reconnaissance. Usages de l'économie sociale et solidaire en Aquitaine, Pessac: Presses universitaires de Bordeaux: 55-85.

Radaelli, C. M. (2003) 'The Europeanisation of Public Policy', in K. Featherstone and C. M. Radaelli (eds) The Politics of Europeanisation, Oxford: Oxford University Press, pp. 27-57.

Reuter, M. (2007) Networking a Region into Existence? Dynamics of Civil Society Regionalization in the Baltic Sea Area, Berlin: Berliner Wiessenschafts Verlag.

Ritaine, E. (2001) 'Cherche capital social, désespérément', Critique Internationale, 12: 48-59.

Salamon, L. M. and Anheier, H. (1995) Defining the Nonprofit Sector, Manchester: Manchester University Press.

Seibel, W. and Anheier, H. K. (1990) 'Sociological and Political Science Approaches to the Third Sector', in H. K. Anheier and W. Seibel (eds) The Third Sector Comparative Studies of Nonprofit Organizations, New York: De Gruyter: 7-20.

Taberna, G. (2009), 'Visite du responsable de l'agriculture de la CAB', Le Journal du Pays Basque, 21 January.

Tejerina, B. (2001) 'Protest Cycle, Political Violence and Social Movements in the Basque Country', Nations and Nationalism, 7(1): 39-57.

Totoricagüena, G. (2005) 'Diasporas as Non-central Government Actors in Foreign Policy: The Trajectory of Basque Paradiplomacy', Nationalism and Ethnic Politics, 11: 265-97.

Zubiaga Garate, M. (2008) Boteretik eraginera: mekanismoak eta prozesuak Leitzarango eta Urbina/Maltzagako liskarretan, Dpto. de ciencias políticas y de la administración, Leioa: Euskal Herriko Unibertsitatea, unpublished thesis. Online. Available www. inguma.org/produkziodatuakgakoa.php?produkzio_gakoa $=27841$ \&hizkuntza $=$ fr (accessed 22 February 2010). 



\section{Part III}

\section{Civil society outside Europe}





\title{
7 Governance and non- governmental organizations in East Asia
}

\section{Building region-wide coalitions}

\author{
Julie Gilson
}

\section{Introduction}

There is substantial debate within East Asia about the nature of civil society, but little agreement as to what it might actually signify in terms of governance structures and democratization. Alagappa notes that there have been many protests in the region, but to suggest that this reflects a build-up of civil society voices may be to overstate contemporary reality (Alagappa 2004: 4). Some scholars regard civil society as a Western concept that cannot be applied with ease to East Asia, while others suggest that it has strong links with economic development and regard the growth of civil society mechanisms as a reflection of a maturing economy. More recent scholarship has introduced the concept of 'global civil society', most often characterized as a direct response to the socio-cultural, political, economic and institutional forces of globalization (Armstrong et al. 2004). The trans-border dimension of civil society forms the focus of this chapter, which examines participation in transnational advocacy networks through an understanding of the nature of the networks being formed and the means and targets of the advocacy being pursued. In addition, and given the contestations over the very idea of this region, the chapter also examines the extent to which projects of integration in East Asia affect and are affected by non-governmental activities. In order to analyse the role played by transnational groups, this chapter adopts a typology of action based on the work of Edwards and Foley (2001) and applies it to both the organizational structures of groups and the strategies they employ.

The need to advocate at differentiated levels of authority means that the idea of seeking redress and lobbying those in power is changing across the world, as accountability mechanisms become more disparate. Information is passed rapidly from one group to another, the means of building a wider range of coalitions have proliferated and forms of authority and redress are seen to lie beyond state thresholds. For some scholars, coalitions of disparate interest groups even herald the dawn of a global civil society, where advocacy can transcend national boundaries (Wapner 1995: 313; Della Porta et al. 2006: 16; Saguier 2004: 9). Indeed, Cohen and Rai note that even when people are rooted in specific local realities, communication technologies permit a form of transnationalism that has 
created 'social fields' which bring disparate actors together (Cohen and Rai 2000: 14). Others illustrate how governance structures have become more fragmented and decentralized and that contemporary governance must therefore be regarded as multi-layered (Rumford 2003: 33; Scholte 2000: 143). In essence, the goals of those who advocate centre on the need to seek representation for the marginalized and to find forms of accountability for actions by higher authorities. For Ebrahim and Weisband the slippery term 'accountability' refers broadly to a means of control that contains within it four facets: transparency, so that information is made available for public scrutiny; justification, or making sure that institutional leaders give clear reasons for their actions; compliance, or monitoring and evaluating actions taken; and enforcement, or sanctions in the event that actions are not taken as promised or required (Ebrahim and Weisband 2007: $2-4)$. The role of advocacy groups in securing accountability is therefore to expose publicly areas in which transparency is not forthcoming; to appeal directly to state leaders or their representatives to explain the reasons for their actions; to publish - now in a wide variety of communication channels - and disseminate information regarding areas where compliance has not been met; and although their enforcement actions may not include institutional sanctions, these may be achieved through gaining public support for petitions, boycotts and other forms of popular action against state decisions.

\section{The idea of region in East Asia}

Before defining and examining the role of various transnational networks, it is worth mentioning briefly how the very concept of regionalism in East Asia is currently being developed. ${ }^{1}$ From the origins in 1967 of the Association of South-East Asian Nations, to the 1997 ASEAN Plus Three process (including Japan, South Korea and China) and the first East Asian Summit in 2005 (adding India, Australia and New Zealand), there have been numerous institutional attempts to organize the states in this broad region into various political, economic and security frameworks. In the case of ASEAN, one of the principal collective goals has been to ensure the mutual respect of sovereign rights and territories and to uphold the cherished principle of non-interference. At the same time, ASEAN has moved towards closer economic cooperation, notably through its ASEAN Free Trade Area, designed to lower intra-regional tariffs (www.aseansec.org). In addition, a new 'ASEAN Charter for ASEAN Peoples' came into force in December 2008, with the aim of responding to the financial crisis and emphasizing political-security, economic and socio-cultural dimensions. This third dimension is especially important for offering a 'platform for engagement with representatives from governmental agencies, educational institutes and civil society organisations' (www.aseansec.org). The extension of regional cooperation in the form of the East Asian Summit has led to calls for the development of an East Asian Community, although at present regionalizing projects remains focused on the closer integration of ASEAN with a supporting role by the 'Plus Three' states. A number of observers have noted how 'newly empowered civil 
society elements' are beginning to use regional institutions to promote their agenda (Acharya 2003: 377-8), and how non-state actors may even be creating a 'sense of a regional community with common concerns and shared values', which itself may lead to new state responses (Yamamoto 1996: xii). Grugel, too, sees new forms of regionalism as being a 'central element in global governance' and for her new forms of regionalism offer new spaces for 'civil society activism' (2006: 210). Mittelman takes a slightly different route to a similar conclusion when he notes that 'transformative regionalism is partly a defensive reaction mounted by those left out of the mosaic of globalisation' (2000: 128-9). All of these cases see the potential for a distinct form of regional activism, but different groups will instrumentalize and be affected by the institutional and discursive parameters of regionalism in different ways.

Despite such institutional developments in East Asia, where governance institutions are often perceived to be less legalistic and formal, it is necessary to examine not only the physical reality of regional institutions, but also the very discourse of region that currently inhabits government and non-government ways of framing policies, particularly over issues that are seen to transcend national boundaries. What is clear from the examples below is that there is not simply one way of framing the region of Asia, either cognitively or institutionally, and that the way the very concept of region is employed by transnational networks may be affected by personal linkages, the ways in which groups are organized and the strategies they adopt.

\section{Transnational advocacy networks}

Networks may be regarded as agents of change that play the role of intermediary and advocate between those in power and the marginalized (Hudson 2001: 333). Edwards and Foley offer a useful point of departure for understanding transnational networks when they categorize them as: socializers, welfare providers or politicizers. First, as socializing agents of change, whose remit is based on the aims and objectives of their donors, they may seek to advance a community towards the development and maintenance of democratic rights and thereby seek to empower or bolster a citizenry (Edwards and Foley 2001: 5; see also Armstrong et al. 2004). To this end, close collaboration with host governments, local community groups or other groups in terms of implementing policies on the ground may cause practical difficulties when participating groups in a network do not share the same principles as one another despite having the same aims and goals. Second, as welfare providers, they often require some coordination in order to avoid unnecessary duplication in terms of the type and target of their provisions. However, decisions over the provisions to be offered and the underpinning prerequisites of donors may complicate any plans for collaboration, while NGOs themselves may become, unwittingly at times, pawns in debates over humanitarian assistance and aid, human rights and accountability (Duffield 1994). Third, by playing a politicizing or contestatory function, NGOs may put pressure on governments or even protest against the state (Edwards and Foley 
2001: 6; Gilson 2009). Thus, a project of resistance may challenge the very principles upon which state (or supra-state) action is based (Armstrong et al. 2004). Riker shares many of these categories in his assessment of South-East Asia, and adds that networks may seek autonomy from the state or may bypass it altogether (Riker 1995). Literature on transnational advocacy networks also points to the fluidity and voluntary nature of these structures which do not carry with them underlying assumptions of shared values, and which will be developed through the process of engagement itself (Hudson 2001: 334). In addition, they may be more necessary where attempts to advocate against a state from within are fruitless, and they can therefore serve an important purpose in addressing different levels of decision making simultaneously (van Tuijl and Jordan 1999). The roles outlined above may depend to a large extent upon the organizational structures of the networks and the strategies they choose to adopt.

First, the composition of the participating organizations may vary tremendously: from large-scale groups organized on both corporate and bureaucratic lines, to small-scale, local ad hoc groups; from those addressing a plethora of issues in the name of, for example, environmentalism or anti-globalization, to others focused on very localized and specific targets. They may also derive from a need to participate within or alongside international events or conferences, such as the International Women's Conference or the Asia-Europe Meeting (ASEM). In a field in which an array of disparate and differently constituted NGOs come together, the summit to which their shadows cling can offer the central point of reference for all participants. When this reference point is regularized, moreover, the summit itself offers a forum for networking and socialization among NGO agents. While they may lobby and even become influential through persuasion, they may have no direct control of resources and frequently may not be very transparent themselves. In addition, the problem of inexperience, a dearth of resources and a lack of coordination can inhibit effective organization. What is more, different groups hold their own particular frames (based on, for example, culture, social roles or academic disciplines) and the ways in which they frame issues will determine whether or not cooperation or conflict will ensue (Pahl-Wostl et al. 2007). These factors mean that when such organizations come together in coalition they may not easily be able to formulate 'strategic approaches' to those in authority they seek to challenge (Kim 2004: 25). In addition, although the process of engagement may lead to improvements in some of the organizational structures of participating groups and even to the creation of a 'collective intentionality' (Park 2004: 85; see also Cummings et al. 2006: 576), the ways in which their differing social structures are negotiated will determine the behaviour of networks, as 'inter-network politics' can constrain a group's ability to come to decisions and take collective action (Carpenter 2007: 644).

Second, the strategies adopted by a network may impact on their efficacy. Two approaches to networking are outlined by Clark et al., who examine those NGOs seeking to liaise with other NGOs and those trying to lobby governments for change (Clark et al. 1998: 9). This distinction is important for understanding 
accountability: active lobbyist and advocacy campaigns seek explanation, justification and redress; network-oriented NGOs have as their primary goal to develop relations with like-minded groups and to make their purpose and structures more professional. In the case of parallel summitry, although they may be convened for short-term purposes and may not seek long-term mobilization (Santa Cruz 2004: 4), networks may de facto have a cumulative impact as they develop and refine common strategies and share best practice among the members of the group leading to 'collective action frames' (Mundy and Murphy 2001).

Keck and Sikkink (1999: 98) outline five stages of network influence: issue creation and agenda setting; influencing discursive positions of states and regional and international organizations; influencing institutional procedures; influencing 'target actors', which may be states, international or regional organizations, or private actors; and influencing state behaviour. Furthermore, the tactics used to achieve those goals are also important. First, the production and dissemination of information are essential to the definition of an advocacy network, and how it can generate and exchange information effectively. In so doing, groups may in fact help to create new issue areas or ways of interpreting them, and transform the very terms of debate (Keck and Sikkink 1999: 90). Park (2004) also notes that as communicative structures networks may also reshape or reconstitute the identity of international organizations, through the transmission of intersubjective norms, a factor that may be important in a regional setting where the very definition of that region is contested. Second, in the model created by Keck and Sikkink (1998), symbolic politics enable networks to develop a normative power and to expand their arsenal of ideas, symbols and different forms of leverage. Third, they address leverage politics, whereby networks use their collective strength to influence outcomes. For this reason, there is a constant (re)negotiation among different claimants within the process and the role of 'weaker' participants cannot be ignored. Finally, accountability politics means that in today's reality a 'thickened' network of accountability locates formal mechanisms and their attendant sanctions alongside informal and discrete areas of input from multiple levels with different kinds of effects (Harlow and Rawlings 2006: 5).

\section{A word about the state}

Santa Cruz (2004: 1) offers a succinct review of the ways in which international civil society and transnational social movements have even come to throw into doubt the continued relevance of the state, in the face of the proliferation and growing relevance of non-state actors). Tarrow, for example, sees in transnational movements the potential to 'challenge the continued autonomy, sovereignty and control by the national state over its own territory' (1998: 6; see also Meyer and Tarrow 1998: 4). Indeed, for Evans such networks play an important counter-hegemonic role, linking poor communities into global hegemonic networks (Evans 2000: 231, cited in Hudson 2001: 335). Walzer (1998) questions the ongoing relevance of the state, while Wapner (1995) talks about 'politics 
beyond the state'. In a similar vein other commentators address the oppositional qualities of non-governmental groups and social movements, as they 'promote or ... resist social change with the use of public protest activities' (Neidhardt and Rucht, cited in Santa Cruz 2004: 2; Meyer and Tarrow 1998: 4). However, despite the growing visibility of non-state actors, it is not yet clear that the state is defunct (Santa Cruz 2004: 1). As will be suggested below, these statements neglect to account for the role of international coalition building precisely as a means of lobbying state governments within East Asia, and this chapter will suggest that, in agreement with Santa Cruz, 'the fact remains that as the constitutive elements and ultimate enforcers of those regimes, states remain the central actors - and the focal point for transnational action' (2004: 28).

The very act of gathering alongside or within official institutional boundaries means that state agencies can have a strong influence on network behaviour. States can also form an important part of a network's ability to perform, providing financial or other types of support, in addition to which they decide on inclusion. Thus, in the case of some state-led institutional engagements (such as ASEM), government organizers have been warmly inclusive of business but decidedly cool about the prospect of including non-governmental organizations. Keck and Sikkink's (1991: 1) boomerang pattern is an important representation of how campaigning groups can work: where a domestic group feels that its interests are not being addressed by its own state, it seeks partners (especially in developed countries) to influence that state's behaviour. In this way, where leverage within state boundaries is weak, a domestic non-governmental organization can collaborate with similar groups beyond national boundaries to create collective leverage against that state. The need to reach back to the state may, however, skew non-state agendas, so that, for example, a land issue may be reframed as an environmental issue in order to obtain the necessary support (Lerche 2008: 239). In summary, 'policy targets, issues, mobilization, and other organizational structures may strictly remain national and local, even when one of these elements takes a transnational guise (McCarthy 1997).

\section{Civil society in East Asia}

Alagappa (2004: 6) notes a 'tendency in Asia, as elsewhere, to bracket civil society, idealize it as the moral conscience of society, and project its development as critical for democratic transition and consolidation'. Some scholars argue that civil society is a Western concept; others that it has strong links with economic development (Alagappa 2004: 12-13). Win reflects on this rise of civil society within East Asia alongside economic development: in part, there has been a need to protest against the hardships brought about by rapid economic development on marginalized communities, for both labour and the environment. In the same context, Win also observes the concurrent economic and political rise of the urban middle classes, whose participation lies at the heart of NGO activities (1998: 104). This scholarship sits alongside the reality of a rapid growth in the number of NGOs in East Asia, where there has been a general rise 
of NGO activity during the past decade in particular (Yamamoto 1996: 5-6, cited in Win 1998: 102). This growth resulted in part from the development of an 'Asian arm' to several international movements, as well as from the recognition of domestic groups of a need to act regionally, both to confront trans-border problems and to address particular 'local' needs. More funding and international changes also led in the 1980s to far more NGO activity around Asia, while a number of topics became extremely fashionable. In particular, the burgeoning of environmental activism had a major influence on advocacy in the region. As one Human Rights Watch report (1998) observed at the time of the Asian preparatory meeting for the 1993 Vienna World Conference on Human Rights, there was an 'impressive regional network, well-versed in international human rights standards'.

In addition, there was a shift in focus as political repression lessened and concern grew over various marginalized groups, such as ethnic minorities and women. The expanded usage of the Internet also quickened the pace of social learning and development among such networks. Thus, with a changing international environment, new forms of regime in the region itself and the organic growth of groups seeking accountability, there is now an accepted, or at the very least somewhat tolerated, role for NGOs in many parts of Asia. Significantly, networks have

evolved from a narrow domestic focus to a more international outlook, embracing global issues and working in solidarity with regional and international movements in the struggle for human rights, sustainable development and environmental protection whilst continuing important social welfare and development work on the domestic front.

(Win 1998: 102)

This entails an increased participation at other regional and international levels in order to gain greater leverage and strengthen domestic claims. Alongside this growth in NGOs has been a proliferation of policy research institutes, such as the Conference on Security and Co-operation in East Asia and the Pacific (CSCAP) and think tanks such as the ASEAN Institute for Strategic and International Studies (ASEAN-ISIS). Such institutions have a role to play in the consolidation and dissemination of ideas (Yamamoto 1996: 11).

These developments have led to two changing perspectives. First, various governments throughout East Asia have identified the growing role of the nongovernment sector, and several networks retain strong links with particular governments. Many states now talk of the need for NGO inclusion in policy making or implementation, and regional groups such as ASEAN talk of the need to include greater NGO participation. However, states may also resist such inclusion; thus, while Thailand and the Philippines have begun to embrace NGOs, China and Indonesia still have a long way to go before these organizations come to be officially accepted. Second, as Yamamoto (1996: xii) notes, with the rise of regional NGOs there has been a concomitant expansion in the use of the concept 
of the region. Many of the groups in the region pay lip service to the regional parameters within which they function and attach their claims to growing institutional frameworks.

Against this growing background, then, there are more resources, experience and shared knowledge, and an awareness of the obstacles facing them, which have spurred the development and consolidation of inter-NGO networks. In the case of East Asia such political layering has resulted in new transnational networks, particularly over the issue of environmental protection (Kock 2006; Reimann 2005). And while the 1980s saw a rapid growth in the NGO sector in East Asian countries, even more dramatic has been the accompanying increase in the networking within countries and between countries - both within the region and with other regions. While in previous years NGOs within the region had a tendency to view one another with suspicion and a sense of rivalry, they have made marked attempts to improve relations among themselves, particularly within countries. Much of the existing tension is a result of differing views and positions vis-à-vis government, or of competition for what are often perceived as scarce financial resources from donors. This situation has greatly improved through increased interaction among NGOs and through growing networks of NGOs in Asia. The following section examines two networks, by tracing their origins, organizational capacities and strategies for advocacy.

\section{Transnational networks in Asia: Forum-Asia and ANGOC}

\section{The nature of the groups}

The region of East Asia is peppered with a variety of transnational acronyms, whose constituent groups have come together at different moments and for many different reasons. This section draws on different networks from Asia, but examines in detail two particular networks, selected because of the variety of their membership, topic specificity, longevity and membership numbers. Forum-Asia involves 40 organizations from 15 Asian states and issued from consultations among human rights and development NGOs in Manila in December $1991 .^{2}$ Its current executive committee includes representatives from Nepal, Bangladesh, Indonesia, the Philippines, Malaysia, Mongolia and Sri Lanka and it has a secretariat in Bangkok. Its membership includes a diverse array of NGO types and different legal registrations, such as Odhikar in Bangladesh (set up in 1994 by a group of human rights activists, see www.odhikar.org). Many of these groups, like the Cambodian Human Rights and Development Association (ADHOC) set up by former political prisoners in 1991 (www.adhoc-chra.org), and the Judicial System Monitoring Programme (JSMP, www.jsmp.minihub.org) in Timor Leste, were established as a result of particular domestic political changes. Many of the constituent NGOs of Forum-Asia have formal structures (such as a board of directors and various committees) and websites, and are members of other transnational fora. As a result, they are increasingly becoming professionalized through these international networks of association. Forum-Asia itself has a 
policy-making executive committee, which also supervises the secretariat and is elected by a general assembly held once every three years. The individual NGOs belonging to Forum-Asia have developed research and publication capabilities within their own regions (such as the Think Centre in Singapore, www.thinkcentre.org). Most significantly, they share a broad remit to establish and protect fundamental human rights, and many of their vision statements include universal declarations as well as localized demands.

The Asian NGO Coalition for Agrarian Reform and Rural Development (ANGOC) shares many characteristics of Forum-Asia, and is a regional network of 21 national and regional NGOs from 11 Asian countries, actively engaged in food security, agrarian reform, sustainable agriculture and rural development activities (www.angoc.ngo.ph). ANGOC was founded in Bangkok in February 1979, following a two-year series of village- and national-level consultations in ten Asian countries leading to the World Conference on Agrarian Reform and Rural Development (WCARRD, Rome, 1979), under the auspices of the UN's Food and Agriculture Organization. It claims that its member networks have an effective reach of some 3,000 NGOs throughout the region. The chair and vice chair of the board between 2004 and 2007 came from the Philippines and Japan, while other board members came from, inter alia, Bangladesh, Cambodia, China, India, Indonesia, Nepal, Pakistan and Sri Lanka. In addition, ANGOC promotes its network members, such as the Asian Institute for Rural Development (AIRD), South Asia Rural Reconstruction Association (SARRA), and the South East Asia Rural Social Leadership Institute (SEARSOLIN), alongside national member groups such as the Association of Development Agencies in Bangladesh (ADAB), the Cambodian NGO Alliance for Cooperation (CNAC), the China Association for NGO Cooperation (CANGO) and the Japanese NGO Center for International Cooperation (JANIC). Given the nature of the overall remit, it is no surprise that many of these groups are very localized, sparsely staffed organizations, with no website and few resources. By the very nature of its constituents, then, this network is more disparate than Forum-Asia, and tends to focus on the particular needs of target communities that have become marginalized as a result of the processes of globalization.

Forum-Asia and ANGOC share characteristics with many of the networks around Asia, whose disparate compositions and varied remits nevertheless tend to follow a number of trends. First, it is worth pointing out that transnational advocacy groups are not a new phenomenon in Asia and those working in a few key topic areas in particular have been around for a long time. These include the Pan-Pacific and South-East Asian Women's Association (PPSEAWA), the Center for Asia-Pacific Women in Politics, and the Asia Pacific Women, Law and Development (APWLD, www.apwld.org). One further issue that attracts a lot of network attention, as Söderbaum and Godsäter note in their contribution to this volume, is the environment. Although they are usually established to tackle localized and specific issues such as the building of a dam (www.ftope.org.tw), environmental issues are generally portrayed as a global problem relating to the degradation of the planet. For this reason, although the specific outcomes sought 
may vary from one issue to another, the coalition groups are seen to form part of an important means of developing datasets and acting as monitors of a global set of problems that are intrinsically linked, and it is this discursive interlinking that often holds groups together. Finally, there is a proliferation of networks engaged in human rights issues, such as the Asia Pacific Human Rights Network, with its secretariat in New Delhi, which campaigns on specific issues within countries as well as providing training to human rights activists (www.aphrn.org). As shown by the APWLD and others, groups often combine issue areas in their activities.

The second trend among Asian networks is the rise in regional summitry, which has spawned the establishment of a number of networks as a result of direct participation in, or as a direct response to, international summits, most notably those held by the United Nations. One notable example is the AsiaPacific Women's Watch, a network that advocates and monitors the implementation of the Beijing Platform for Action (BPFA) and the outcome document from the UN General Assembly on Women 2000, or Beijing + 5. The South East Asia Watch, or SEAWatch, was created for the same purpose. A more recent example is the Asia-Europe People's Forum (AEPF), which emerged in the mid-1990s, to shadow directly the newly created Asia-Europe Meeting (ASEM) of heads of state from the European Union and East Asia. The AEPF organizes a range of civil society meetings on the margins of ASEM summits and is an important portal for the sharing of information and for forming and implementing joint initiatives in the face of government (in)decisions. In its Final Declaration of October 2008, following its meeting alongside the Beijing ASEM summit, the AEPF, in its stated spirit of 'critical engagement' with states, called for specific actions to be taken by member states. These include the abolition of the antiterrorist laws implemented as a result of the so-called 'war on terror'; the strengthening of the International Criminal Court; legislation to remove US bases from the regions of Europe and Asia; and the phased withdrawal of foreign troops from Afghanistan and Iraq (www.tni.org). The AEPF has also emphasized its role in creating and expanding the space for transnational interaction among different non-state actors. The membership of the AEPF does not shadow directly that of ASEM, but is open to all groups from Asia and Europe.

Third, there are networks that may be regarded as functioning arms of international organizations. They include international non-state organizations such as Greenpeace Southeast, which has been tailored in response to the particular needs of this region in addition to the national chapters of the group (www. greenpeace.org). In a similar way, Transparency International has created a global set of regional networks which aim to combat corruption and share information by focusing on the particular needs of the local environment in which they work. In Asia its group has four sub-regional groups. Since 2004, several national chapters have become more professionalized, now managing growing budgets and implementing multiple projects. One further example is the International Women's Rights Action Watch Asia Pacific. It works through collaborative projects in order to achieve the domestic application of international human rights norms in relation to women's rights. In summary, then, these 
groups accommodate a range of actors and target communities, but are linked by commonly understood themes and increasingly through professional structures.

\section{Strategies for advocacy}

A number of networks bring together individuals, such as women lawyers, while others attract the participation of already established groups, creating bigger networks. Networks may have different targets: they may focus on trying to change the policies of a particular state or trying to attract the attention of a regional or international organization. They may or may not be linked to, and sponsored by, external donors or international organizations. Their objectives also vary, but the examples of Forum-Asia and ANGOC typify the approaches of many regional networks.

Forum-Asia aims to 'empower people by advocating social justice, sustainable human development, participatory democracy, gender equality, peace and human security through collaboration and cooperation among human rights organisations in the region' (UNHCR 2010). In order to achieve these goals, its members have recognized a need to establish a network of organizations at the local and global levels through which to develop 'effective engagement with state and non-state actors'. As it draws on a broad set of issues situated around the idea of human rights, the scope of issues enables Forum-Asia to act as a coherent amalgamation of interests. For the most part, the Forum has worked to influence larger fora, by adopting a strategy of parallel summitry. In particular, it works very closely with the UN and since 2004 has enjoyed consultative status within the UN Economic and Social Council (ECOSOC). It has also used such engagement as a means of lobbying the Human Rights Council in Geneva. In Clark et al.'s terms noted above, Forum-Asia has a network-oriented role to act as a mechanism for capacity building among regional, 'local', NGOs. However, this role is seen as a cornerstone for the principal aim of activist lobbying against particular state actions, where the target of action is the states of the region themselves. Specific campaigns to date have included: a fight to highlight and seek redress for those adversely affected by chemical mining in Mongolia; seeking justice for victims of the 1991 Santa Cruz massacre in Timor Leste; lobbying against the human rights record of the Lao government; and encouraging the South Asian Association for Regional Cooperation (SAARC) to prioritize human rights issues. Thus, the Forum is viewed as providing its members with a means of monitoring state actions from an 'above-region' or 'beyond-region' position.

ANGOC's mission is to

create a policy and social environment that enables Asian Rural Poor Communities to exercise their rights to participatory development, gain access to and control of their natural resources, and engage in sustainable livelihoods while drawing from Asia's rich spiritual and cultural traditions.

In so doing, it aims to promote alternative development experiences in agrarian reform, sustainable agriculture and rural development, as well as to strengthen 
Asian grassroots action networks. In a similar vein to Forum-Asia, its original aim was to facilitate communication and coordination between government and nongovernment organizations, with respect to agrarian reform and rural development at national levels. In particular, ANGOC has focused on linking grassroots social action groups with larger institutional formats, through institutions such as the Asian Development Bank (ADB) and the UN Conference on Environmental and Development (UNCED). It also works closely with private international campaign groups such as Friends of the Earth, in order to increase public interest and awareness and begin to address accountability issues related to the major development banks. So successful has been this campaigning that in 1992 ANGOC was elected onto the NGO Working Group on the World Bank and its Steering Committee in 1993. ANGOC aligns itself with many other groups, creating networks in a number of areas, such as networks on food security, agrarian reform, sustainable agriculture, and capacity building for which ANGOC was elected as a member of the International Steering Committee of the International Forum on Capacity Building (IFCB) for Southern NGOs at the international conference held in May 1998 in Brussels. ANGOC has launched and worked on many programmes, including, for example, the 1985 promotion of GO-NGO-donor relationships, and it has a history of working together with other organizations around the world. For example, from 1991 to 1996, ANGOC organized the Asian Development Forum (ADF) to look at community-based resource management, sustainable agriculture, sustainable livelihoods, transforming institutions and people-centred sustainable development. Over 25 years, the ANGOC network has written numerous reports and organized over 100 regional and national conferences, workshops and training courses. A key factor in the work of ANGOC is to disseminate information, which is also crucial for spreading the word about how networks breed and influence other networks. A key element in promoting people's participation has been the strengthening of the capacity of grassroots groups or people's organizations - not only NGOs - to become involved in decision making about development (www. fao.org). All of these initiatives respond to a belief that top-down governmental approaches do not lead to the legitimate involvement of the people in organizations. Both Forum-Asia and ANGOC have provided much needed resources and learning experiences to their members, as well as facilitated technical cooperation and significant linkages with external groups. Indeed, studies on the NGO sector in different Asian countries have provided opportunities for ANGOC members to build their research and documentation capabilities. Through the proliferation of workshops, conferences, study visits and channels for communication, these two networks, in addition to the other networks mentioned, have enhanced the development of an 'NGO community' within Asia.

Although the means to achieving their ends have focused principally on the need to create more effective networks, the implicit target of many of the initiatives proposed by Forum-Asia and ANGOC has been the policies of particular states. Forum-Asia's most recent statements to the UN Human Rights Council in Geneva included concerns over police assaults on freedom of expression in South Korea, calls for the Sri Lankan government to facilitate human assistance 
for internally displaced persons and concerns over the deportation of Tibetan refugees by the Nepali government. This is consistent with the work of ANGOC, which has sought since 1997 to make an explicit link between calls for macrolevel reforms and grassroots provisions (www.angoc.ngo.ph/200vp).

\section{The nature of the region}

There is no clear idea of the region within the networks illustrated in this chapter. These organic and fluid structures may be loosely based on a geographical frame of reference, but are primarily attached to specific targets. Instead, the groups tend to instrumentalize the idea of the region for particular purposes, rather than deriving their remits from it or being overly influenced by it. Forum-Asia, for example, records in its stated goals a need to strengthen its 'regional dimension'. It clearly, therefore, has an idea that there is a 'region' to appeal to and represent, although its membership would suggest the widest interpretation of region. However, it utilizes an implied rather than applied idea of region, as it does not specifically identify institutions. The geographical frame of region is used by the Forum in order to shape the issues they work on, which include Dalits, Tibet and South Korean democracy, all regarded as part of 'our' region. And although the network frequently appeals to the decision makers of ASEAN, there is no sense that the region has an institutional role to play. Like Forum-Asia, ANGOC takes national concerns and priorities and uses this region-wide forum to influence state policy. In addition, the very disparate membership has led to calls for greater attention to be paid to the establishment of national directories and national coordination, in order primarily to create and maintain formal mechanisms for interaction with national governments. These are then seen as 'intermediate NGOs' with the task of 'organizing and mobilizing primary groups, and acting at times as intermediaries between government and people's organizations' (www.fao.org/docrep). The role of the region for ANGOC, then, is a discursive-cultural one, wherein ANGOC aims to promote sustainable development by building on a common 'Asian identity and values'. Here too this notion is left vague. Other networks follow similar patterns. For example the AsiaPacific Human Rights Network and the APWLD use the region to demarcate (loosely) their membership, but tend to focus on national strategies. The PPSEAWA, too, seeks to develop a more comprehensive network of activists within the broad 'Pan-Pacific' and 'South-East Asia' region in order to bolster a community of interests, but without having the region as an identifying agent, beyond these broad geographical borders.

\section{Conclusion}

ANGOC and Forum-Asia, like many other networks, evolved over time through the amalgamation of organic interests and the influence of international external fora. They derived from local groups seizing an opportunity for external representation and from the socialization process that came with getting together for 
the sake of participating in and with larger fora. Not only did they issue from these gatherings, but they also spawned new groups and in this way they are testament to how networks breed networks. Both groups have now been going for some time and have developed into broad memberships of increasingly professionalized NGOs, coming together as networks under the loose and adjustable banners of human rights and agrarian reform. This conclusion assesses the significance of the nature of the groups and their forms of advocacy, as well as the influence of the state and region on the functioning of networks.

First, the target issue of the network is likely to influence outcomes. Where a group of women lawyers come together with a specific target they are likely to create a more coherent coalition in the name of the environment. They bear out the findings of Moog Rodrigues (2002: 2), who shows that 'the level of homogeneity of perceptions, interests, and expectations among the target-group or population facilitates the formulation of a common approach'. In this way, the closer the frames of reference of the constituent participants, the greater the likelihood of success for a network. For this reason too, even seemingly straightforward issues where agreement might be anticipated can result in inter-network constraints when the ideational origins of the parties involved in the network are too different (Carpenter 2007: 644). In their work, Keck and Sikkink focus on the relative attributes of the issues taken up by networks, while Carpenter (2007: 646) notes in addition a need to see how 'savvy advocates gravitate toward 'hot' issues likely to draw donor funding and good media coverage for their organizations'. Thus, the issues of human rights, women and the environment may not simply be the most pressing issues impacting on local communities, but may also be the areas where greater funding is available.

Second, the nature of the network is likely to affect advocacy outcomes. These networks bring together disparately constituted small, local groups under the banners of, for example, environmentalism or human rights. The examples of Forum-Asia and ANGOC demonstrate how the choice of issue is important in creating the scope to accommodate diverse interests. At the same time, the professionalization of networks is becoming more important and the more developed those structures, the more likely that internal divisions can be addressed and overcome.

Third, the strategies adopted by a given network will affect its efficacy. The networks illustrated above all have varied approaches to advocacy. In the main, historically, they have responded to particular issues in localized areas, which may or may not have wider implications. For this reason, they have traditionally focused on being welfare providers. In terms of campaigning, moreover, the networks commonly adopt cooperative strategies among regional groups and simultaneously network with international organizations. In the cases of Forum-Asia and ANGOC, the terms of campaigns are so broad and the internal structures so fluid that there has been apparently little inter-network tension. In terms of the five tactics outlined above, the most important is information politics. Both networks regard their primary role as to convey information to a wide audience. In terms of symbolic politics, there is both the suggestion that NGOs per se have 
become more politically acceptable to governments in the region, and that there is a greater need to address local contexts. However, in general they appear to be strongly influenced by international organizations and therefore tend to imbibe rather than redraw the international terms of debate. They use such normative frames to influence local governments, and this also links into leverage politics. These factors contribute to the development of accountability politics, as international norms of reference (in, for example, environmental management or human rights) are used vis-à-vis national policy makers. In the light of these findings, transnational networks tend to focus more on the 'self-reflexive strategy which targets changing global decision-making structures and supporting local level struggles', rather than attempting to seek 'autonomous and provide forceful alternatives' to the current order (Mundy and Murphy 2001). The networks illustrated do not campaign principally for changes to the world order or to the norms of advocacy. But aside from their particularistic concerns, they are influential in creating greater information about advocacy and challenging prevailing ways of seeking accountability.

Fourth, more attention needs to be paid to the role of states. In this preliminary sweep of the region, one key finding is that there is no apparent negation of the importance of the role of individual states. As noted in the previous section, networks of regional activists come together to lobby collectively specific states with reference to particular policy decisions. In so doing, they may draw upon the expertise, professionalism and normative frame of reference of international organizations. These networks appeal to regional and global governance structures precisely because they regard them as means to influencing particular state policy makers. Forum-Asia and ANGOC are making important attempts to influence national strategies. Far from ignoring or superseding the role of the state, then, they are seeking means of leverage to seek changes to what they regard still to be primordial state authority. As Human Rights Watch discovered, the 'focus of all of these and other organizations that emerged in the region at the time [early 2000s] was very specifically restoration of political and civil rights at home' (1998: 157). There is, then, tremendous value in being able to lobby outside the country that is, de facto, the destination target. As a result of this form of lobbying we can see, in the area of human rights, for example, Human Rights Watch identify a growing cooperation between government human rights institutions and NGOs. At the same time, Lerche (2008: 239) warns of a possible skewing of agendas to achieve the 'boomerang' effect, so that, for example, 'conflicts over land and related problems of poverty and inequality may be reframed as environmental issues, and a focus on violence against women may substitute for a general move against patriarchy'. This has not evidently been the case for the examples illustrated here, although many of them have a broad remit that could accommodate a reallocation or relabelling.

Finally, where does the region of Asia feature in the formation and maintenance of networks in Asia? The role of the region for these networks has principally been implied. Both Forum-Asia and ANGOC span a large number of countries and have a fairly straightforward relationship with the idea of region. 
The other groups similarly derive from personal networks and are equally open and fluid in their membership. The region is invoked frequently by all the networks, but in a variety of ways. Thus, the idea of region serves as a useful geographical frame for these groups, but it may also be applied to justify certain values and a mythical-historical reference to a community of shared values. In the case of Forum-Asia and ANGOC, for example, each identifies something 'Asian' about what it does. But this tends to represent a generic set of fluid values. It is principally a cognitive tool, although the physical rise of institutions means that there is more institutional engagement at a regional level. This institutional element is growing and as regional governments begin to embrace NGOs then there may be more of a coherent regional dimension to advocacy coalitions in the future, which may in turn influence the development of the region. Thus, while future networks may contribute to regional integration (Keck and Sikkink 1999: 89), at the moment the region tends to be used as another point of leverage, in addition to the 'international'.

In summary, advocacy networks in East Asia should not be regarded as part of a rise of global civil society or as a response to greater international engagement. Rather, they offer an important means of disseminating and sharing information and resources, and an additional means of leverage for influencing national politics. In so doing, although critical of states, transnational networks implicitly affirm the legitimacy of state authority within regional governance. This bears out Santa Cruz's statement that 'the fact remains that as the constitutive elements and ultimate enforcers of those regimes, states remain the central actors - and the focal point for transnational action' (2004: 28). In these circumstances, there is considerable need for a greater understanding - through a systematic review of all transnational advocacy networks in Asia - of how ordinary people are beginning to state their claims in novel ways.

\section{Notes}

1 East Asia is broadly defined here as those countries involved in the ASEAN Plus Three process: namely, the states of ASEAN, and Japan, South Korea and China. The problems with this distinction will become clear throughout this chapter.

2 Its members come from Bangladesh, Burma/Thailand, Cambodia, Malaysia, Mongolia, Nepal, Pakistan, Philippines, Singapore, South Korea, Sri Lanka, Taiwan and Timor Leste.

\section{References}

Acharya, A. (2003) 'Democratisation and the Prospects for Participatory Regionalism in Southeast Asia', Third World Quarterly, 24(2): 375-90.

Alagappa, M. (ed.) (2004) Civil Society and Political Change in Asia: Expanding and Contracting Democratic Space, Stanford, Calif.: Stanford University Press.

Armstrong, D., Lloyd, L. and Redmond, J. (2004) International Organisation in World Politics, Houndmills: Palgrave Macmillan.

Carpenter, R. C. (2007) 'Studying Issue (Non)-Adoption in Transnational Advocacy Networks', International Organization, 61: 643-7. 
Clark, A. M., Friedman, E. J. and Hochstetler, K. (1998) 'The Sovereign Limits of Global Civil Society: A Comparison of NGO Participation in UN World Conferences on the Environment, Human Rights, and Women', World Politics, 51(1): 1-35.

Cohen, R. and Rai, S. M. (eds) (2000) Global Social Movements, London: Athlone Press.

Cummings, S., Heeks, R. and Huysman, M. (2006) 'Knowledge and Learning in Online Networks in Development: A Social-Capital Perspective', Development in Practice, 16(6): 570-86.

Della Porta, D., Andretta, M., Mosca, L. and Reiter, H. (2006) Globalization from Below: Transnational Activists and Protest Networks, Minneapolis, Minn.: University of Minneapolis Press.

Duffield, M. (1994) 'Complex Emergencies and the Crisis of Developmentalism', Institute of Development Studies Bulletin, 25(4): 37-45.

Ebrahim, A. and Weisband, E. (eds) (2007) Forging Global Accountabilities: Participation, Pluralism and Public Ethics, Cambridge: Cambridge University Press.

Edwards, B. and Foley, M. W. (2001) 'Civil Society and Social Capital: A Primer', in B. Edwards, M. W. Foley and M. Dini (eds) Beyond Tocqueville: Civil Society and the Social Capital Debate in Comparative Perspective, Hanover, NH: University Press of New Hampshire: 1-17.

Evans, P. (2000) 'Fighting Marginalization with Transnational Networks: Counterhegemonic Globalization', Contemporary Sociology, 29: 230-41.

Gilson, J. (2009) 'Learning to Learn and Building Communities of Practice: Nongovernmental Organisations and Examples from Mine Action in Southeast Asia', Global Society, 23(3): 269-93.

Grugel, J. (2006) 'Regionalist Governance and Transnational Collective Action in Latin America', Economy and Society, 35(2): 209-31.

Harlow, C. and Rawlings, R. (2006) 'Accountability and Law Enforcement: The Centralised EU Infringement Procedure', European Law Review, 4: 447-75.

Hudson, A. (2001) 'NGOs' Transnational Advocacy Networks: From "legitimacy" to “Political Responsibility”?', Global Networks, 1(4): 331-52.

Human Rights Watch (1998) Human Rights Watch World Report, New York: Human Rights Watch.

Keck, M. and Sikkink, K. (1998) Activists Beyond Borders: Advocacy Networks in International Politics, Ithaca, NY: Cornell University Press.

Keck, M. E. and Sikkink, K. (1999) 'Transnational Advocacy Networks in International and Regional Politics', International Social Science Journal, 159: 88-99.

Kim, J. (2004) 'Accountability, Governance, and Non-Governmental Organizations: A Comparative Study of Twelve Asia-Pacific Nations', The International Society for Third-Sector Research (ISTR), 'Contesting Citizenship and Civil Society in a Divided World', Ryerson University and York University, 11-14 July. Online. Available www. istr.org/conferences/toronto/workingpapers/kim.junki.pdf (accessed on 12 May 2010).

Kock, B. E. (2006) 'Engaging Non-Governmental Organizations with International Environmental Negotiations: Institutional Approaches to Reforming State-NGO Interactions'. Online. Available www.pon.org/downloads/ien15.4.Kock.pdf (accessed on 17 March 2009).

Lerche, J. (2008) 'Transnational Advocacy Networks and Affirmative Action for Dalits in India', Development and Change, 39(2): 239-61.

McCarthy, J. D. (1997) 'The Globalization of Social Movement Theory', in J. Smith, C. Chatfield and R. Pagnucco (eds) Transnational Social Movements and Global Politics: Solidarity Beyond the State. Syracuse, NY: Syracuse University Press: 243-59. 
Meyer, D. S. and Tarrow, S. (1998) 'A Movement Society: Contentious Politics for a New Century', in D. S. Meyer and S. Tarrow (eds) The Social Movement Society: Contentious Politics for a New Century, Lanham, Md.: Rowman and Littlefield: 1-28.

Mittelman, J. H. (2000) The Globalization Syndrome: Transformation and Resistance, Princeton, NJ: Princeton University Press.

Moog Rodrigues, M. G. (2000) 'Searching for Common Ground - Transnational Advocacy Networks and Environmentally Sustainable Development in Amazonia', paper prepared for the workshop 'Human Rights and Globalization: When Transnational Civil Society Networks Hit the Ground', University of California, Santa Cruz, Center for Global, International, and Regional Studies, 1-2 December. Online. Available http:// www2.ucsc.edu/globalinterns/cpapers/rodrigues.pdf (accessed on 17 March 2009).

Mundy, K. and Murphy, L. (2001) 'Transnational Advocacy, Global Civil Society? Emerging Evidence from the Field of Education', Comparative Education Review, 45(1): 85-126.

Pahl-Wostl, C., Craps, M., Dewulf, A., Mostert, E., Tabara, D. and Taillieu, T. (2007) 'Social Learning and Water Resources Management', Ecology and Society, 12(2): 5. Online. Available www.ecologyandsociety.org/vol. 12/iss2/art5 (accessed on 1 January 2009).

Park, S. (2004) 'The Role of Transnational Advocacy Networks in Reconstituting International Organization Identities', Seton Hall Journal of Diplomacy and International Relations, Summer/Fall: 79-92.

Reimann, K. (2005) 'Transnational NGO Networks, the Asian Development Bank and the Rise of Society in Regional Politics in East Asia', paper presented at the International Studies Association, Honolulu, Hawaii, March. Online. Available www.allacademic.com/meta/p70167_index.html (accessed on 17 March 2009).

Riker, J. (1995) 'Contending Perspectives for Interpreting Government-NGO Relations in South and Southeast Asia', in N. Heyzer, J. Riker and A. Quizon (eds) GovernmentNGO Relations in Asia: Prospects and Challenges for People-Centred Development, Basingstoke: Macmillan: 15-55.

Rumford, C. (2003) 'European Civil Society or Transnational Social Space?: Conceptions of Society in Discourses of EU Citizenship, Governance and the Democratic Deficit', European Journal of Social Theory, 6(25): 25-43.

Saguier, M. I. (2004) 'Convergence in the Making: Transnational Civil Society and the Free Trade Area of the Americas', CSGR Working Paper No. 137/04, June. Online. Available www2.warwick.ac.uk/fac/soc/csgr/research/workingpapers/2004/wp13704. pdf (accessed on 17 March 2009).

Santa Cruz, A. (2004) 'The Emergence of a Transnational Advocacy Network: International Election Monitoring in the Philippines, Chile, Nicaragua, and Mexico', Portal, 1(2): $1-31$.

Scholte, J. A. (2000) Globalization: A Critical Introduction, Basingstoke: Palgrave.

Tarrow, S. (1998) Power in Movement: Social Movements and Contentious Politics, 2nd edition, Cambridge: Cambridge University Press.

UNHCR (2010) 'Asian Forum for Human Rights and Development, NGO Directory, 1 October 2008'. Online. Available www.unher.org/48fdeb8016.html (accessed on 7July 2010).

van Tuijl, P. and Jordan, L. (1999) 'Political Responsibility in Transnational NGO Advocacy’, World Development, 28(12): 2051-65.

Wapner, P. (1995) 'Politics Beyond the State, Environmental Activism and World Civic Politics', World Politics, 47: 311-40. 
Walzer, M. (ed.) (1998) Toward a Global Civil Society, Providence, RI: Berghahn Books. Win, A. A. (1998) 'The Growing Civil Society in Asia: An Overview and Proposals for Future Action', in A. Bernard, H. Helmich and P. B. Lehning (eds) Civil Society and International Development, Paris: North-South Centre of the Council of Europe Development Centre of the Organization for Economic Cooperation and Development: 99-110.

Yamamoto, T. (ed.) (1996) Emerging Civil Society in the Asia Pacific Community: Nongovernmental Underpinnings of the Emerging Asia Pacific Regional Community, Singapore: Institute of Southeast Asian Studies. 


\title{
8 Civil society in regional governance in Eastern and Southern Africa
}

\author{
Andréas Godsäter and Fredrik Söderbaum
}

\section{Introduction}

The relatively scant emphasis given to civil society in studies dealing with regionalism would seem to suggest the low relevance of civil society in this regard. This is unfortunate because, as this chapter elaborates, civil society is a dynamic force at the regional level and deserves deeper analysis. To this end, this chapter seeks to contribute to the debate about civil society's role in regional governance in Eastern and Southern Africa. We argue that the neglect of civil society in the study of regional governance is at least partly a theoretical and conceptual problem. As emphasized in the first part of this chapter, it is necessary to acknowledge the heterogeneity of links between civil society and states that arise in different socio-cultural and political contexts. We argue in particular that theories and conceptualizations of civil society rooted in the Western or European experience risk misunderstanding the logic of African civil society and its involvement in regional governance.

We delimit our empirical focus by concentrating on Eastern and Southern Africa. This focus is justified by the distinct history of civil society interaction in this part of Africa during decolonization, the recognized and quite distinct overall regionalization dynamic, and a multitude of state forms with different links to their respective civil societies. The most comprehensive understanding of Eastern and Southern Africa covers the Common Market for Eastern and Southern Africa (COMESA), the East African Community (EAC), and the Southern African Development Community (SADC) group of countries, but there are also other informal and dynamic sub-regions within this definition. It is noteworthy that civil society interactions do not follow the membership of intergovernmental regional organizations. The next section discusses some theoretical and conceptual points of departure for the analysis of civil society in regional governance in Africa and presents a typology of four types of civil society involvement in regional governance. Based on this typology, the empirical section examines civil society involvement in regional governance in Africa. 


\section{Framework}

We take our point of departure from a reflectivist and critical perspective towards the study of regionalism, which has become established as the New Regionalism Approach (NRA). ${ }^{1}$ The NRA conceptualizes regionalization as a multidimensional process, occurring in many sectors and on different levels simultaneously, and driven by a variety of state and non-state actors. The NRA is based on a triangle of regionalizing actors, broadly grouped in terms of states (governments), markets (business) and civil society. One basic assumption is that not only economic, but also social and cultural, regional networks and projects are anticipated to develop more quickly than the formal state-led regionalist projects. Rather than separating actors into perceived 'autonomous' groups or spheres of actors, the NRA suggests that actors will be grouped in formal or informal multi-actor networks, partnerships and modes of regional governance (Söderbaum 2004). Some key theorists in the NRA camp, such as Hettne and Mittelman, build on the ideas of Karl Polanyi about the political role of civil society as a means for the weak and the poor to protect themselves against often exploitative market forces in the context of economic globalization. In doing so, these scholars emphasize the counter-hegemonic and transformative role of civil society regionalization, such as pro-democracy forces, women's movements and environmentalist groups. As Mittelman points out: '[A]t the end of the day, the possibilities and limitations of transformative regionalism rest on the strength of its links to civil society' (2000: 225). In a similar fashion, Marchand draws attention to the regionalization of civil society in North America as a civil society-led counter-force against the 'hyper liberal' North American Free Trade Area (NAFTA), the former representing 'the best' and the latter 'the worst' of the new regionalism in North America (2001: 210). This notion of civil society's counterhegemonic and transformative potential reflects the deep dissatisfaction of these authors with neoliberal globalization and their eagerness to discover an alternative order. Even if we are sympathetic to the critical and transformative ambitions of such analysis, we argue for a broader and more open-ended framework, which is able to reflect a wider set of empirical outcomes (see Söderbaum 2007).

There is a rich variety of definitions and meanings of 'civil society' (Scholte 2000, 2002). It is often loosely defined as the public realm and the associational life existing between the state and the private sphere. From this perspective civil society is seen as an arena where different associations and interest groups can express their interests and engage with the state. Although not always conceptualized in this way, civil society is generally considered to be distinct from the state. Scholte defines civil society as a political space where voluntary associations, intentional or unintentional, shape the rules that govern one or more aspects of social life (2002: 147). It includes a rich variety of actors and voluntary associations, such as non-governmental organizations (NGOs), communitybased organizations, interest groups, trade unions, social movements, faith-based organizations, academic institutions, clan and kinship circles, lobbies, youth associations and development cooperation initiatives (grouped here collectively 
as civil society organizations, CSOs). A group's active political orientation is an important ingredient in this definition, but both profit-seeking actors and political parties are excluded, since they pursue a direct quest for political power. However, contrary to Scholte, we argue that those voluntary associations that do not attempt to shape policies, norms or structures in society (for instance NGOs engaged in service delivery) are worth including in the study of civil society, since their activity contributes to the reproduction of the current social system.

Most studies on civil society are heavily influenced by Western and liberal thinking. This implies focusing on the civility, autonomy and sovereignty of civil society. From such perspectives, only organizations with a normative potential may be considered part of civil society, ruling out for example certain ethnically and religiously based organizations (Chazan 1999: 111). Furthermore, according to liberal thinking, civil society has to be understood in terms of its own qualities and not in relation to the state (Azarya 1994: 83). We argue that one reason why civil society in Africa is widely misunderstood by scholars is the dominance of Western (liberal) political thought. Indeed, many African social scientists argue that the liberal concept of civil society needs to be contested; the liberal idea of an 'autonomous' civil society is a myth. Civil society cannot be seen in isolation, only in connection to the corresponding state and, according to these scholars, liberals fail to recognize the pluralism of state-society interaction in Africa (Mamdani 1995; Kasfir 1998). Many Africanist scholars consider civil society to be conflictual and contradictory, different civil society actors penetrating the state in different ways and vice versa (Habib 2004). Critics also argue that there is a tendency to idealize civil society, conceptualizing it as homogenous and inherently democratic (Sjögren 1998). According to one critical scholar, ' $[t]$ his tendency involves nothing less than a one-sided anti-state romanticisation of civil society' (Mamdani 1995: 603). Another weakness in the conventional understanding of civil society is that a great deal of research in this field is based on the notion that civil society operates, and is consolidated, on a 'national' basis. In our view, this notion must be transcended in order to provide a perspective beyond the national government and provide a better account of civil society on the supranational regional level. In other words, civil society is not hermetically sealed from the external environment. On the contrary, civil society activities at different levels/scales tend to be closely connected.

The framework developed here seeks to problematize civil society and to embrace a theoretical perspective that allows for the possibility that civil society contains an internal series of paradoxes and conflicts. Our framework also seeks to account for the fact that civil society actors may be involved in complex, rather than simple and straightforward, relationships with other types of actors, which, in turn, may blur the distinctions between civil society actors, states and private market actors. External actors also play an important role in the promotion of civil society in Africa (Howell 2000). According to one commentator, however, generally this is seldom done on African terms since foreign donors tend to 'bring in funds and consultants to shape civil society according to their own agenda' (Muchie 2003: 71). 


\section{A typology of civil society in regional governance}

The concept of governance provides an opportunity to get out of the conceptual prison of state-centrism. In particular, the nation-state is being reorganized and non-state actors have assumed many responsibilities and functions traditionally reserved for the state. There is therefore a need to think in terms of more complex, multilevel and polyarchic modes of governance, which take into account the dispersal of power, authority, legitimacy, jurisdictions and responsibility. Governance should not be confused with government: governance is more than government and in order to be able to speak of governance and 'systems of rule' there must be a certain degree of control and continuity. Although the current analysis emphasizes the regional level, as already indicated, the regional is interwoven with and closely related to other levels and scales, not least the national level. Although it is often possible to identify a distinct 'regional' arena, activities on the 'national' and 'regional' levels are intimately interconnected. Even if CSOs engage regionally, they are first and foremost based and active within a national context. For example, many regional CSOs support the national work of their members and partners. What is of particular importance is how the regional arena manifests itself and how various types of CSOs use it to further their (local, national and regional) interests. This will be illustrated below. Furthermore, we contend that a strong emphasis on formal and public dimensions of governance in much of the literature has prevented a more comprehensive understanding of the subject matter. In order, then, to understand the emerging and prevailing modes of governance and the interests and purposes they serve, it should be recognized that they are more than simply formal public systems of rule and authority structures for goal achievement (Jones 1998: 2). It is also crucial to acknowledge the fact that civil society contributes to and tries to shape, resist or even manipulate regional governance.

In line with Gilson's chapter in this volume, we argue that the complex and multifaceted nature of civil society warrants some kind of categorization of the roles that civil society play in regional governance. Drawing on Armstrong et al. (2004), our typology emphasizes four partly competing types of civil society participation in regional governance: (a) civil society as partner in regional governance; (b) civil society as legitimating regional governance; (c) civil society as resisting regional governance; and (d) civil society as manipulating regional governance. Partner CSOs engage with state actors and regional interstate frameworks on a consultative basis, mainly in order to solve joint problems. These CSOs are fairly content with formal regional governance, even if they believe that some policies and programmes need to be modified and implementation accelerated. Therefore, they play a monitoring role in relation to state actors, making sure that public policies are implemented and governments deliver what they have promised to deliver, as well as lobbying for the modification of regional policies. They also take a direct role in the provision of social services together with governments, especially in marginalized areas. This creates a partnership-based relationship. The second type of CSOs serves the function of legitimizing regional governance, 
trying to fill the so-called democratic deficit within regional interstate frameworks. The legitimating CSOs critically engage state actors by advocating policy reform. However, legitimizing CSOs, like the partner CSOs, still underpin current governance structures but make them more accountable and legitimate. Third, civil society when resisting regional governance seeks to achieve a structural change in current regionalist regimes. These CSOs question the use of problem-solving activities, believing that pure service provision merely reproduces a highly unjust society and the prevailing capitalist order. Instead, the patterns of unsustainable development must be identified and transformed, and this can only be done through popular mobilization. The interaction with state actors is therefore contentious. It is when manipulating regional governance that civil society becomes a repressive force, and serves as an instrument for narrow private economic and political gains. It is widely recognized in Africa that NGOs may be destructive forces in society. Even if so-called 'briefcase NGOs' or 'My Own NGOs' (MONGOs) may fulfil certain functions, their main purpose is to extract resources from those willing to pay. In principle CSOs manipulating regional governance have little interest in investing time and money in regional governance, or in taking part in regional civil society networks, unless this enables them to extract rents or achieve other goals. The following section applies these four typologies to the region of Eastern and Southern Africa.

\section{Civil society in regional governance in Eastern and Southern Africa}

The relationships between state and civil society need to be problematized. In the case of Africa, the role of the state varies between every society, as does the extent of state intervention in the economy and across society in general. The typology developed in the previous section is useful for categorizing the roles that civil society plays in regional governance. We focus on two broad sectors: sustainable development and social and economic justice (the latter group's civil society actors operating in various fields, such as trade, debt and HIV/AIDS). The reasons for choosing these two sectors are threefold and built on our experiences in the field: (a) regional cooperation in these sectors is rich; (b) the civil society configuration is different in the two sectors, which creates a basis for comparison; and (c) both sectors show a high involvement of donors. It should be noted that although we believe that we have captured some of the most important patterns in these sectors, our empirical coverage is not exhaustive. Instead we have used illustrative examples for each of the four types. Dividing lines between the types are seldom sharp in the real world and some CSOs may fit more than one type.

\section{Civil society as partner in regional governance}

Those parts of civil society that can be understood as partners in regional governance basically accept and support the agenda formulated by regional inter- 
governmental organizations, such as the EAC, the SADC and COMESA. The political instruments for achieving socio-economically and environmentally sound regional governance are mostly in place, even if they need some finetuning. The main challenge is to accelerate the implementation of existing programmes and policies. It is possible to distinguish between two roles that civil society plays as partner: in service delivery and in lobbying/monitoring. Several partner CSOs perform both functions, albeit in different mixes. Osienala Friends of Lake Victoria is a regional NGO based in Kisumu, Kenya, with 15 partner organizations in Kenya, Tanzania and Uganda. The main objectives are to enable partners and other development CSOs around Lake Victoria, provide various services to local communities regionally and lobby local, national and regional policy makers (Osienala 2010). Osienala has a radio station, Radio Lake Victoria, which seeks to educate fishing communities around the lake regarding environmental management. Furthermore, Osienala has been assigned as lead agent by the Kenyan government in assisting NGOs in Environmental Impact Assessments and maintains a close working relationship with the states-led Lake Victoria Basin Commission (LVBC). ${ }^{2}$ In short, the LVBC provides policy guidance on sustainable natural resource management at the same time as it seeks to coordinate and facilitate development activities by both state and non-state actors in the basin area (LVBC 2007).

The East African Communities' Organization for Management of Lake Victoria Resources (ECOVIC) is a regional network comprised of three country chapters in Tanzania, Kenya and Uganda with about 30 national member NGOs and community based organizations (CBOs) altogether. A regional secretariat is based in Jinja, Uganda. ECOVIC's activities include service delivery, advocacy, lobbying, network building and capacity building for the sustainable use of Lake Victoria's resources and enhanced regional integration (ECOVIC 2007). ECOVIC is very active in the regional arena. With regard to service delivery, among other things it provides sanitation facilities and clean water in various communities in the Lake Victoria region. Most activities are carried out in close collaboration with local authorities. ECOVIC is also involved in lobbying, for instance towards the East African Legislative Assembly (EALA), the independent legislative arm of the EAC with the mandate to oversee its work (EALA 2010). In this regard, ECOVIC holds meetings and workshops with members of the EALA and suggests improvements in policy making related to the use and management of Lake Victoria's resources. ECOVIC has also been granted observer status in the EAC Council of Ministers. Furthermore, ECOVIC collaborates with the Lake Victoria Fisheries Organization (LVFO), a regional organization under the EAC responsible for coordinating and managing fisheries resources of Lake Victoria (LVFO 2010a). One important example of joint state-civil society regional governance is the so-called 'co-management initiative', a partnership arrangement in which local communities, local governments and other stakeholders share responsibility and the authority for the management of the fishery. Co-management is partly implemented through the so-called Beach Management Unit-system (LVFO 2010b), set up and supported by 
Osienala, ECOVIC and the LVFO. According to one representative of ECOVIC, the interaction with the LVFO is 'smooth'.

In Eastern African, regional CSOs often collaborate with state actors in policy making and seem to have developed a good relationship. One example is the Eastern African Sub-regional Initiative for the Advancement of Women (EASSI), a regional membership-based CSO with headquarters in Kampala, Uganda, linking 16 national women's associations in eight countries in Northern and Eastern Africa around the promotion of gender equality and women's rights. ${ }^{4}$ As part of its work, EASSI assesses the implementation by regional governments of the so-called Beijing Platform for Action (BPFA), a UN initiative that sets out measures to ensure that a gender perspective is reflected in all policies and programmes at the national, regional and international levels (EASSI 2010). EASSI also organizes regional civil society fora, for example within the realm of the Women's Affairs Ministers Meetings in the region, bringing together policy makers and CSOs for policy dialogue (EASSI 2007). In addition, EASSI is collaborating with the EAC to put in place a regional gender declaration. According to representatives of EASSI, there is a general openness for partnership with civil society on the part of the EAC. ${ }^{5}$ Similarly, the Advocates Coalition for Development and Environment (ACODE) is a regional independent policy research and advocacy NGO based in Kampala, Uganda, with several partners throughout the region. Its mission is to influence development and governance policies for the promotion of social justice in Eastern Africa, through policy research, advocacy and community empowerment (ACODE 2007). Based on its own research, ACODE provides governmental institutions in Uganda, as well as EAC institutions, with policy options that are environmentally sound and sensitive to public development concerns. For example, they push the EAC to harmonize further farmers' rights in Eastern Africa. ACODE also sits on a number of governmental technical working committees in Uganda, as do its partners in Tanzania and Kenya. Furthermore, ACODE regularly organizes regional fora for scientists and policy makers on intellectual property rights and development, in partnership with national state agencies. ACODE claims that it has emerged 'as an effective government partner in the policy development process' (ACODE 2007), and that its policy recommendations are taken seriously and incorporated into new acts and bills. ${ }^{6}$

In Southern Africa, the picture is more ambiguous. Here, most lobbying activities centre on the SADC as a counterpart. The Wildlife and Environment Society of South Africa (WESSA) is a South African environmental NGO dealing with both education and advocacy. WESSA is the implementing agency of the SADC Regional Environmental Education Programme (SADC REEP), which is coordinated by the SADC Secretariat. The programme aims to enable environmental education practitioners in the SADC region to stimulate environmental education in their home countries. This is done through strengthening training capacity, the compilation and distribution of information and educational material, and regional networking (WESSA 2010). Other examples of 
policy collaboration with SADC include the Southern African Research and Development Centre (SARDC). This is a resource centre based in Zimbabwe, with a satellite office in Mozambique, which produces and disseminates information about development processes in the SADC region. It works closely with the SADC Secretariat, and the relationship is formalized in a Memorandum of Understanding entitling the SARDC to have a seat in various SADC fora. Through lobbying and research the SARDC tries to influence SADC policy making in areas such as informal trade and the monitoring of the SADC's development programmes. According to the SARDC itself, it is taken seriously because: 'we don't see governments as our enemies ... we want to complement the governments' work. It is clear that SARDC's policy advices are incorporated in many SADC resolutions'. ${ }^{7}$ However, there are many less successful partnerships between civil society and the SADC, especially as far as lobbying is concerned. One important example is the SADC Council of Non-Governmental Organizations (SADC-CNGO), which is a civil society umbrella organization with participants from all over the SADC region. The SADC-CNGO seeks to influence development policies in the SADC, accelerate implementation and put forward NGO interests and perspectives (SADC-CNGO 2005). This endeavour is encouraged by the SADC, which frequently and strongly proclaims the need to involve civil society in regional governance. Paragraph 23 of the SADC Treaty stipulates that:

SADC shall seek to involve fully the people of the Region and nongovernmental organizations in the process of regional integration.... SADC shall co-operate with, and support the initiatives of the peoples of the Region and non-governmental organizations, contributing to the objectives of this Treaty in the areas of co-operation in order to foster closer relations among the communities, associations and people of the Region.

(SADC 1992)

The SADC and the SADC-CNGO have in fact formulated a Memorandum of Understanding on general cooperation where the parties commit themselves to collaborate on the implementation of the goals of the SADC Treaty (SADCCNGO 2003). The SADC-CNGO has been active in arranging a number of SADC civil society fora parallel to the official SADC summits, where the delegates discuss and hope to influence the processes within the SADC (cf. Gilson's chapter for similar processes in Asia). However, the fundamental problem is exclusion. The Secretary General of the SADC-CNGO, Abie Ditlhake, claims that 'in practice, they don't consult us' (quoted in Nduru 2006). The marginalization and exclusion of civil society from the SADC framework are observed by both researchers (Landsberg 2002) and civil society actors (SADC-CNGO 2006), as well as by SADC representatives. According to one official, it is very difficult to have access to the SADC since it is a closed institution, which in reality has not prioritized collaboration with civil society, in spite of resolutions stating otherwise. ${ }^{8}$ Lastly, the African Network of AIDS Service Organizations 
(SANASO) seeks to unite the efforts of national AIDS service CSOs around the region and promote cooperation between civil society and governments. After many struggles, it has managed to establish institutionalized links with the SADC Secretariat, engaged in areas like health and human resources development (SANASO 2010). However, it is uncertain whether SANASO will manage to push and monitor the formation and implementation of policies related to health and HIV/AIDS in the SADC region, as aimed for, considering the tendency of SADC towards exclusion.

\section{Civil society as legitimating regional governance}

Civil society as legitimating regional governance refers to CSOs that seek to collaborate with state actors, but which have a critical engagement more than a straightforward partnership. Their objectives are to enhance policy reform rather than the development and implementation of existing policies, and, ultimately, to make regional governance more accountable and democratic. Their critical approach means that relations with state actors and regional organizations are tenser and more controversial than the previous type. The East African Sustainability Watch Network (EASWN) is a loosely organized coalition of three national networks: the Uganda Coalition for Sustainable Development (UCSD); the Kenya Organization of Environment Education (KOEE); and the Tanzania Coalition for Sustainable Development (TCSD). A regional secretariat is hosted by the UCSD (EASWN 2007). The EASWN's most important project is the East African Civil Society Watchdog Project for Sustainable Development in the Lake Victoria basin, which tries to increase citizen participation in reforming policies related to sustainable development and scaling up networking and information sharing on sustainable development. During the process of establishing the LVBC, the EASWN made a submission to the EAC's Lake Victoria Commission Bill of 2007. In the process it managed to arrange a meeting with the speaker from EALA as well as to hold informal discussions with EALA members, to demand more accountable decision-making procedures and more space for popular participation. ${ }^{9}$ Another example of civil society as legitimator is the National Association of Professional Environmentalists (NAPE), a national advocacy group on environmental issues based in Uganda but operating regionally in East Africa. NAPE lobbies the LVBC to adopt a 'bottom-up' approach when coordinating development activities in the region. According to NAPE, the LVBC and EAC are crucial for governing the development processes in the region, but interaction with local communities and CSOs must be radically improved. Even though NAPE in general is recognized by governmental officials as an important actor in the process, its critical approach creates a contentious relationship. As one interviewee observed: 'if you are advocating for transparency, if you are advocating against non-compliance, very few governmental organizations would want to bring you near'. ${ }^{10}$

In Southern Africa, the Southern African Trade Unions Co-ordinating Council (SATUCC) is a membership-based regional organization based in Botswana, 
formed and constituted by national labour unions throughout the region. The Council coordinates trade union coalitions in the region and serves an advocacy role vis-à-vis the SADC, trying to reform regional socio-economic policy making and incorporate labour issues. According to its secretary general, SATUCC has been successful in interacting with the SADC and influencing policy making, for example by joining a regional tripartite structure with business and SADC states where important policy documents are developed. ${ }^{11}$ Similarly, Mwelekeo wa NGO (MWENGO) is a regional partnership-based NGO based in Zimbabwe, building the institutional capacity and advocacy skills of NGOs in Southern Africa, and dealing with social justice issues through workshops, networking and training. MWENGO tries to enable its partner NGOs to become advocates for more democratic governance institutions, such as the SADC. Its primary objective is to enhance the role and ability of CSOs to participate in the policy-making processes related to development at national and regional levels, and to have the interests of its constituencies represented in various governmental institutions (MWENGO 2009). However, its critical standpoint does leave it increasingly marginalized. The last example of civil society as legitimator is Treatment Action Campaign (TAC), a South Africa-based NGO pushing for increased treatment of people with HIV and reduction of HIV infections in the region through fundamental policy reform. Even though it focuses on the national arena, TAC also arranges regional workshops for HIV/AIDS activists in Southern Africa. Among several regional campaigns, one targeted the secretariat of the Southern Africa Customs Union (SACU) and trade ministries in the region. Through the coordination of TAC, partners in the region collectively demanded that international trade agreements should be opened up for public scrutiny and not jeopardize popular access to AIDS medicines. ${ }^{12}$

\section{Civil society as resisting regional governance}

Examples of civil society resisting regional governance prevail above all in Southern Africa. In contrast to partner and legitimating CSOs, the aims and objectives of states-led regional governance are interpreted differently and resisted, not acknowledged. The current analysis highlights three examples of civil society resisting regional governance: the Southern African Centre for Economic Justice (SACEJ), the Southern African Peoples' Solidarity Network (SAPSN) and the Anti-Privatization Forum (APF). SACEJ is a Johannesburgbased regional activist platform, which addresses issues of economic justice from a regional perspective. SACEJ supports existing and emerging networks and social movements in the region, and seeks to mobilize local communities over issues such as poverty and water. SACEJ organizes joint campaigns and unites community-based struggles in the region. ${ }^{13}$ SAPSN has become established as one of the key nodes in Southern Africa of the so-called 'antiglobalization movement'. The SAPSN network involves a broad range of civil society organizations and institutions, including trade unions, development NGOs, church-based social organizations and community-based movements, all 
working towards regional development and against economic and 'hyper liberal' globalization. Its aims are to share experiences, develop capacity, exchange information, increase awareness, and contribute to the mobilization and building of mass movements. The secretariat is currently based at the Zimbabwe Coalition on Debt and Development (ZIMCODD), another resisting CSO, in Harare, Zimbabwe (SAPSN 2010). SAPSN is critical of much of the state-driven regionalism. It claims that most Southern African political regimes only engage in rhetorical declarations about development cooperation and integration. Various SAPSN statements charge that SADC leaders are using the SADC as a selfserving 'old boys' club' for mutual support 'whenever the interests and power of the ruling elites come into conflict with the human rights, and the democratic and development aspirations of their own populations' (SAPSN 2000). SAPSN's vision emphasizes the limits of state-steered regionalism at the same time as it calls for the effective participation of organized forces of civil society and peoples. Among other activities, SAPSN regularly holds joint regional workshops, hosted by individual SAPSN member organizations, on issues related to regional integration. Some of these workshops have taken the form of people's summits parallel to official SADC meetings (SAPSN 2010). At the summit in August 2006 a plan of action was developed to start the process of reclaiming the SADC for people's solidarity and development cooperation. A People's Declaration was written, criticizing the current SADC process and demanding greater transparency (OSISA 2006). The APF is another example of civil society resisting regional governance. It is an activist platform for 30 community-based organizations and social movements in South Africa contesting the privatization of water, electricity, housing, education and health through direct action. According to a representative of the APF, they refuse to join the 'NGO crowd' and to participate in states-led regional schemes like the African Union (AU) and SADC, which, he claims, bring in civil society only as a means to gain (artificial) public legitimacy. Therefore, its view on the SADC NGO Council, addressed above, is very critical: 'to be very blunt, we think it is a joke and we don't take it very seriously ... It is a classic example of institutionalized cooption' ${ }^{14}$ Even if primarily operating on a national level, the APF is also active in the regional arena and, for example, was instrumental in developing the Social Forum process in the region.

It has to be said that resisting regional governance and striving towards 'transformation' does not automatically make these CSOs positive forces in society or for democracy. Agents of civil society as resisting regional governance have clearly managed to fill a vacuum created by the absence of real alternative state-led regionalisms. But in filling this gap, these agents are not necessarily 'peoples driven', and their frequently proclaimed links to the grass roots and to 'peoples' need to be scrutinized and debated. Sections of resisting civil society are an elite-led process, dominated by a relatively small number of NGO representatives and activists. Contrary to SATUCC (see p. 000 above), most CSOs participating in SAPSN are not membership-based. The number of participants and stakeholders involved is steadily increasing, but the agenda 
and output are dominated by a limited number of vocal activists. Their ability to deliver their message (their 'voice') and to finance their activities is heavily dependent on how successful they are in attracting donor funding or other support from Western NGOs. This is particularly pertinent for regional networking and regional cooperation. These critical factors are not necessarily problematic but they raise questions about legitimacy, accountability and representation. In this way, some resisting CSOs resemble the so-called 'briefcase NGOs' described below.

\section{Civil society as manipulating regional governance}

The CSOs that arise in order to manipulate regional governance for purposes of economic and political profit appear to be closely associated with the prevalence of what are often called neo-patrimonial regimes, such as Botswana, Kenya, Lesotho, Malawi, Rwanda, Swaziland, Zambia and Zimbabwe. Many of the states throughout the region are rentier-based economies whose state forms are ripe for patrimonialism. Indeed, in some African states where neopatrimonialism is strong, it is difficult to distinguish between the state and civil society. Furthermore, many NGOs in Eastern and Southern Africa are staffed by relatives or close associates of the ruling political elites, using civil society as a platform for gaining personal political and economic gain. Such structures may sometimes be justified in cases such as charitable-purpose NGOs. Obviously, there is a thin line between these and problem-solving NGOs. Rentseeking NGOs raise serious issues about independence and undue influence among NGOs and governments. As one well-regarded expert on African politics points out: '[I]f you or anyone else was to look at a[n] NGO in Botswana, the first thing you need to find out is: who is the head and the leading officeholders in the NGO?' Due to often being a 'one-man show', these NGOs in Botswana and elsewhere have been nicknamed 'MONGOs' (My Own NGO). This is not to say that every NGO with government links is compromised, and some may still demonstrate independence by challenging and criticizing government actions and policies. ${ }^{15}$

Political elites and governments may use and abuse civil society in order to gain accountability and legitimacy for their own crumbling regimes. Hence, civil society may play the 'political' role of reinforcing and legitimating controversial, and sometimes repressive, dimensions of regional governance, such as large-scale regional infrastructural projects and state facilitation for the regional operation of big enterprises. This role is played by regional NGOs, or rather 'semi-governmental organizations' (SGOs), which are merely an extension of intergovernmental institutions, and donors, whose development agendas in principle converge. In this type the links with regional state actors are obviously very strong and they often intertwine. Apart from service delivery, such regional NGOs often use propaganda, disguised as 'information-sharing' and 'popular education', as important strategies for their economic and political ends. Indeed, it is a common strategy of many governments in the region to establish research 
institutes, think tanks and NGOs that operate as extended arms of, or fronts for, the government. These actors rarely criticize their benefactor governments, and instead play a role in seeking to legitimize often authoritarian or even illegal government activities. The NGO set up by Zambia's former president, Frederick Chiluba, to debate his (unconstitutional) third presidential term is one classic example. Another example is Ditshwanelo, a human rights NGO in Botswana headed by a daughter of the then foreign minister. It had previously been publicly critical of the government's treatment of the minority San people, but at the 2001 World Conference in Durban on Racism, Racial Discrimination, Xenophobia and Related Intolerance the organization was conspicuously silent on this issue. Ditshwanelo's behaviour was subsequently debated in Botswana, and opinion concluded that the organization had been influenced by this familial link to attempt to minimize international embarrassment for Botswana and its government. ${ }^{16}$

Representatives of the state and civil society actors in Southern and Eastern Africa often mention the fact that manipulative CSOs constitute obstacles for development and regional governance, serving the needs of donors and political and economic elites rather than local communities. According to one commentator, many NGOs in Eastern Africa are formed because 'someone wants to make some quick money somewhere ... or some [donor] agency somewhere has convinced them to form so that ... they can serve as a channel for the agency to do what it wants to do' ${ }^{17}$ The significant inflow of donor money into civil society in Africa and elsewhere in the South has made it 'the place to make money' (Hearn 2007: 1102), generating what Dicklitch and others have referred to as 'briefcase NGOs' (Dicklitch 1998: 8), driven primarily by economic self-interest. In reality, however, such NGOs remain difficult to expose, as they invest heavily in creating a benevolent (development) facade. In general, the quest for making money makes NGOs professionalized and increasingly headed by members of the middle class, revealing a narrow social representation (Dicklitch 1998: 159). Therefore some African NGOs are seen merely as an extension of the dominant donor aid agenda and agents of Western interests. One commentator concludes that many African NGOs have become 'local managers of foreign aid money, not managers of local African development processes' (Hearn 2007: 1107). The briefcase NGOs and many rent-seeking MONGOs are mainly interested in promoting and participating in regional cooperation and governance when they enhance economic or political gain. This is especially so when donors make such funding available. The preliminary finding is that civil society as 'manipulators' may be a bigger problem in national governance than in regional governance.

\section{Conclusion}

This chapter has analysed the role of civil society in regional governance in Eastern and Southern Africa. It has argued that the study of civil society in regional governance is underdeveloped and that there is a need to reflect on how 
it is theorized and conceptualized. In particular, it is important to account for the paradoxes and conflicts within civil society itself, as well as the heterogeneity of links between civil society and states that arise in different socio-cultural and political contexts. The chapter developed a typology outlining four (partly competing and partly overlapping) roles for civil society in regional governance. Civil society as partner in regional governance is carried out by CSOs that engage with state actors and interstate frameworks such as the SADC on a partnership and consultative basis, in order to solve joint problems. Civil society as legitimating regional governance is played by CSOs seeking reformist policy change by critically engaging state actors, often in terms of collective regional lobbying. Civil society as resisting regional governance is played by CSOs that want to see a more fundamental transformation of the current regionalist regimes, building regional social movements through popular mobilization. Finally, civil society as manipulating regional governance occurs when civil society serves as a instrument for manipulation and for achieving narrow private economic and political gains.

Despite a degree of enthusiasm over the prospects for increased interaction between civil society and states in Eastern and Southern Africa during the midand late 1990s, today civil society organizations have in many instances become increasingly marginalized. At the same time, there are several examples of successful civil society participation in regional governance. The general trend is that civil society in Eastern Africa is less radical and more inclined to be a 'partner' or 'legitimator' than in Southern Africa. Generally speaking, there appears to be a more cooperative relationship between civil society and governments in Eastern Africa. However, civil society in Eastern and Southern Africa suffers from internal conflicts and rivalries, due to competition for scarce resources as well as ideological divergences, which in turn influence their relationships with both donors and governments. Even if some CSOs, especially in Eastern Africa, appear to be quite successful in influencing and participating in states-led regional governance, they also suffer from fragmentation. One main reason for this is to be found in the competition for donor funds. CSOs have a tendency to duplicate their work, flooding the currently most popular development sectors while ignoring others. There are no effective mechanisms for consolidating or steering development activities by NGOs and CBOs in the region. For instance, the legitimacy of Osienala to lead regional civil society in Eastern Africa does not seem to extend outside its 15 partner NGOs and ECOVIC seems to suffer from weak internal leadership, a lack of transparency, lack of resources and, not least, conflicts between country chapters. ${ }^{18}$ The overall problem is that the cumbersome quest for donor funding forces national as well as regional CSOs to 'mind their own business'. ${ }^{19}$ When NGOs put most of their effort into trying to secure income, this creates indifference towards what is best for civil society as a whole.

In Southern Africa, the quarrel is often over ideology and strategy towards intergovernmental regional governance. Such quarrels ultimately boil down to the fact that different types of CSOs often have fundamentally different views on 
Southern African regionalism itself. This situation appears similar to the various civil society cross-border initiatives advancing the Basque cause that have ambiguous relations with regional integration in Europe, as presented by Itçaina in this volume. Partner CSOs argue that lobbying is the most effective strategy, and they see the SADC as an important instrument for regional development, even if in need of certain reforms. In contrast, critical voices claim that it is incredibly difficult for us to work with the government' because those who try risk becoming co-opted into a statist, neo-liberal agenda. ${ }^{20}$ Real change for people on the ground can only be achieved by delinking from the state and through the mobilization of people in social movements. ${ }^{21}$ Such disputes over strategies are highlighted at civil society gatherings. At the Southern African Social Forum in Lusaka 2003, for example, there were divisions within civil society. Some CSOs saw their primary role as to lobby their governments to lessen the impact of neoliberalism, whereas more radical social movements had as their objective to challenge the prevailing hegemonic order through social mobilization. These tensions resulted in the failure to present a common plan of action on how the demands raised at the forum should be put forward (Globalise Resistance 2006). And, as we has seen above, the very existence of two different, and competing, civil society fora parallel to the official SADC summits is itself a sign of intra-civil society rivalry.

Divergences related to strategy, as well as ideology, do not necessarily have to lead to divisions within civil society. Indeed, they can also strengthen civil society participation in regional governance. Most observers, both in civil society and in government, seem to agree, however, that civil society in both Southern and Eastern Africa is weakly coordinated and needs to organize itself more effectively on a regional level. ${ }^{22}$ It is claimed that the missing link is 'strategic leadership' and strategic alliance building within civil society. Few CSOs see the potential and usefulness in collaboration over ideological divides. Partner and legitimating CSOs often lack information and knowledge from the ground when doing lobbying and advocacy (that is, their work is not evidence-based), whereas resisting CSOs through social mobilization have a deeper insight into poor people's daily struggles and are better equipped to make a critical politicaleconomic analysis of regional policy making, despite the fact that they refuse to engage with policy makers. Merging such 'insider' and 'outsider' strategies might be the key for successful civil society influence in regional governance around Africa. For civil society to have a stronger impact on regional governance in Eastern and Southern Africa, greater intra-civil society collaboration is needed. We agree with Gilson's findings in Chapter 7 above that the type of strategies adopted, or, more specifically, the combination of strategies, will fundamentally affect the outcome of regional civil society networks and coalitions. In this process, civil society as partner, legitimator and resister need not be mutually exclusive roles in regional governance. 


\section{Notes}

1 For an overview of the NRA and similar approaches, see Söderbaum and Shaw (2003). For more detailed accounts of the NRA, see Hettne et al. (1999) and Söderbaum (2004).

2 Interview with Obiero Ong'ang'a, Osienala, 8 April 2008.

3 Interview with Keefa Kaweesa, ECOVIC Uganda, 13 April 2008.

4 Interview with Jane Ocaya-Irama and Josephine Watuulo, EASSI, 28 March 2008.

5 Interview with Jane Ocaya-Irama and Josephine Watuulo, EASSI, 28 March 2008.

6 Interview with Onesmus Mugynyaki, ACODE, 15 April 2008.

7 Interview with Bayano Valy, SARDC, 21 November 2008.

8 Interview with Janah Ncube, SADC Secretariat, 8 December 2008.

9 Interview with Richard Kimbowa, UCSD, 26 March 2008.

10 Interview with Frank Muramuzi, NAPE, 26 March 2008.

11 Interview with Moses Katchima, SATUCC, 8 December 2008.

12 Interview with Njogu Morgan, TAC, 14 March 2005.

13 Interview with George Dor, SACEJ, 11 February 2005.

14 Interview with Dale McKinley, APF, 1 December 2008.

15 Thanks to Professor Ian Taylor for highlighting these examples.

16 Ibid.

17 Interview with Dr Julius P. Ayo-Odongo, Lake Victoria Local Authorities Cooperation (LVLAC), 14 April 2008.

18 Interviews with Silas W. Ng'habi, Victoria Environmental and Fishery Development Association (VEFDA), 6 April 2008; Obiero Ong'ang'a, Osienala, 8 April 2008; Matano A. Saidi, LVBC, 9 April 2008; and Dr Julius P. Ayo-Odongo, LVLAC, 14 April 2008.

19 Interview with Jennipher A. Kere, Women in Fisheries Industry Programme for Education and Development, 11 April 2008, and Benedict Kwangu, Lake Nyanza Environmental and Sanitation Organization, 1 April 2008.

20 Interview with George Dor, Jubilee South Africa, 4 March 2003.

21 Interview with Diamanthino Nhampossa, UNAC, 31 January 2003.

22 Cf. Landsberg (2002); SADC-CNGO (2005); interview with Neville Gabriel, Southern Africa Trust, 2 December 2008; and interview with Janah Ncube, SADC, 8 December 2008.

\section{References}

ACODE (2007) 'ACODE Annual Report 2006', Kampala: ACODE.

Armstrong, D., Lloyd, L. and Redmond, J. (2004) International Organisation in World Politics, New York and Basingstoke: Palgrave.

Azarya, V. (1994) 'Civil Society and Disengagement in Africa', in J. W. Harbeson (ed.) Civil Society and the State in Africa, Boulder, Colo.: Lynne Rienner, pp. 83-100.

Chazan, N. (1999) Politics and Society in Contemporary Africa, Boulder, Colo.: Lynne Rienner.

Dicklitch, S. (1998) The Elusive Promise of NGOs in Africa: Lessons from Uganda, Basingstoke: Macmillan.

EALA (2010) 'About EALA', Arusha: EALA. Online. Available www.eala.org/abouteala (accessed 1 March 2010).

EASSI (2007) 'EASSI Annual Report 2006’, Kampala: EASSI.

(2010) 'Monitoring the Implementation of Commitments to the Platforms for Action', Kampala: EASSI. Online. Available www.eassi.org/programmes/Monitoring $\% 20$ the $\% 20$ Implementation $\% 20$ of $\% 20$ Commitments $\% 20$ to $\% 20$ the $\% 20$ Platforms\%20for\%20Action.php (accessed 1 March 2010). 
EASWN (2007) 'SusWatchdog. Newsletter of EASWN, December 2007', Kampala: UCSD.

ECOVIC (2007) 'Operational Plan for Sustainable Utilisation of Lake Victoria Resources', Jinja: ECOVIC.

Globalise Resistance (2006) 'SASF Lusaka 2003', London: Globalise Resistance. Online. Available www.resist.org.uk/reports/archive/sasf/index.html (accessed 7 October 2006).

Habib, A. (2004) 'State-Civil Society Relations in Post-Apartheid South Africa', in J. Daniel, A. Habib and R. Southall (eds) State of the Nation: South Africa 2003-2004, Johannesburg: HSRC Press, pp. 227-241.

Hearn, J. (2007) 'African NGOs: The New Compradors?', Development and Change, 38 (6): 1095-1110.

Hettne, B., Inotai, A. and Sunkel, O. (eds) (1999) Globalism and the New Regionalism, New York: Macmillan.

Howell, J. (2000) 'Making Civil Societies from the Outside - Challenges for Donors', European Journal of Development Research, 1 (12): 3-22.

Jones, B. (1998) 'Governance and the Challenges of Changing Political Space', mimeo, Reading: University of Reading.

Kasfir, N. (1998) 'The Conventional Notion of Civil Society: A Critique', in N. Kasfir (ed.) Civil Society and Democracy in Africa: Critical Perspectives, London: Frank Cass, pp. 1-20.

Landsberg, C. (2002) 'Building a Regional Society in Southern Africa: The Institutional Governance Dimension', Policy: Issues and Actors, 15 (1). Online. Available www. cps.org.za/cps\%20pdf/pia15(1).pdf (accessed 22 February 2010).

LVBC (2007) 'Shared Vision and Strategy Framework for Management and Development of Lake Victoria', Kisumu: LVBC.

LVFO (2010a) 'About the Lake Victoria Fisheries Organization', Jinja: LVFO. Online. Available www.lvfo.org/index.php?option=displaypage \&Itemid=135\&op=page (accessed 1 March 2010).

_ (2010b) 'Co-management of the Fisheries of Lake Victoria', Jinja: LVFO. Online. Available www.lvfo.org/index.php?option=displaypage\&Itemid=114\&op=page (accessed 1 March 2010).

Mamdani, M. (1995) 'A Critique of the State and Civil Society Paradigm in Africanist Studies', in E. Wamba-dia-Wamba and M. Mamdani (eds) African Studies in Social Movements and Democracy, Dakar: Codesria, pp. 602-616.

Marchand, M. H. (2001) 'North American Regionalisms and Regionalization in the 1990s', in M. Schulz, F. Söderbaum and J. Öjendal (eds) Regionalization in a Globalizing World. A Comparative Perspective on Forms, Actors and Processes, London: Zed Books, pp. 198-210.

Mittelman, J. H. (2000) The Globalization Syndrome. Transformation and Resistance, Princeton, NJ: Princeton University Press.

Muchie, M. (2003) 'Civil Society and Pan-Africanism', in M. Muchie (ed.) The Making of the Africa-Nation - Pan-Africanism and the African Renaissance, London: Adonis \& Abbey.

MWENGO (2009) ‘About Us', Harare: MWENGO. Online. Available http://69.13.173.12/ subpages.aspx?id=26 (accessed 3 February 2009).

Nduru, M. (2006) 'SOUTHERN AFRICA: Two Days, and Lots of Problems', Inter Press Service, 17 August 2006.

Osienala (2010) 'About Us', Kisumu: Osienala. Online. Available www.osienala.org/ aboutus.php (accessed 23 February 2010). 
OSISA (2006) 'SADC Peoples Summit 2006', Johannesburg: OSISA. Online. Available www.osisa.org/node/3717 (accessed 17 October 2006).

SADC (1992) 'Treaty of the Southern African Development Community', Gaborone: SADC.

SADC-CNGO (2003) 'Memorandum of Understanding on General Co-operation between SADC and SADC-CNGO', Gaborone: SADC-CNGO.

_ (2005) 'SADC-CNGO Strategic plan 2005-2008', Gaborone: SADC-CNGO.

(2006) 'Communiqué from the SADC Civil Society Forum in Lesotho, 2006', Gaborone: SADC-CNGO.

SANASO (2010) 'Partnerships', Windhoek: SANASO. Online. Available www.sanaso. org.zw/partnerships.htm (accessed 1 March 2010).

SAPSN (2000) 'Making Southern African Development Cooperation and Integration a People-centered and People-driven Regional Challenge to Globalisation', Cape Town: AIDC. Online. Available http://aidc.org.za/sapsn/report/workshop_20000801.html (accessed 2 February 2006).

- (2006) 'Reclaiming SADC for Peoples Solidarity and Development Cooperation', Cape Town: AIDC. Online. Available www.aidc.org.za/?q=node/view/653 (accessed 3 October 2006).

(2010) 'About SAPSN', Harare: ZIMCODD. Online. Available www.zimcodd.org. zw/index.php?option $=$ com_content\&task=view\&id=25\&Itemid=95 (accessed 1 March 2010).

Scholte, J. A. (2000) 'Global Civil Society', in N. Woods (ed.) The Political Economy of Globalization, New York Palgrave, pp. 173-201.

— (2002) 'Civil Society and Governance', in M. Ougaard and R. Higgott (eds) Towards a Global Polity, London: Routledge, pp. 145-166.

Sjögren, A. (1998) 'Civil Society and Governance in Africa - an Outline of the Debates', Working Paper n.1, Research Programme: Cities, Governance and Civil Society in Africa, Uppsala: Nordic Africa Institute. Online. Available www.statsvet.su.se/publikationer/sjogren/anders_sjogren_csgov.pdf (accessed 22 February 2010).

Söderbaum, F. (2004) The Political Economy of Regionalism. The Case of Southern Africa, New York: Palgrave Macmillan.

- (2007) 'Regionalisation and Civil Society: The Case of Southern Africa', New Political Economy, 3 (12): 319-337.

Söderbaum, F. and Shaw, T. M. (eds) (2003) Theories of New Regionalism. A Palgrave Reader, New York: Palgrave.

WESSA (2010) 'SADC REEP', Howick: WESSA. Online. Available www.wessa.org.za/ index.php/Programs/SADC-REEP.html (accessed 1 March 2010). 


\title{
9 The role of civil society in regional governance in the Middle East
}

\author{
Michael Schulz
}

\section{Introduction}

This chapter considers the issue of how regional civil society networks and their activities in the Middle East impact on regional governance. The role of a Middle East civil society has rarely been researched from a regional perspective. This reflects the fact that most analysts do not see the potential for regional integration there. The theory of new regionalism has occasionally been applied to the Middle East context, despite the fact that the region's integration is usually envisaged as slow or even unlikely (see Harders and Legrenzi 2008; Lindholm Schulz and Schulz 2005). The region tends to be described as post-Westphalian, states still playing the most important role. Nevertheless, many regional projects have not only been launched, but have also been discussed by various players in the Middle East, as well as outside the region, and civil society representatives have been involved in these discussions. Civil society not only acts within each country in the region, but also through transnational networks. In this way, it constitutes a forerunner not only to regionalization but also to democratization in the regional context.

Before the 1990s, in order to identify the potential for political change the state was seen as one key actor alongside elites within the Middle Eastern states. However, in the 1990s civil society came to be part of the political agenda in the Middle East. In relation to the potential for democratization, one could see statements such as: '[n]o doubt, the defining flavor of the 1990s is participation' (Norton 1995: 5). Others emphasized the developmental capacity of civil society, not least its 'Islamic' sector, claiming that it provided help to the poorest and those in greatest need. More recent research has been critical of these assumptions, and suggests that civil society is still a marginal part of Middle Eastern states. Islamic civil society, often criticized for not constituting one, has rather been seen as a breeding ground for Islamic radicalism and jihadists (Kramer 2001).

\section{The conceptual definition of civil society and its application to the Middle East}

The concept of civil society is admittedly a contested notion, as illustrated throughout this volume. Here, civil society is used to mean voluntary associ- 
ations outside the realm of the state itself. Civil society, however, requires a relationship with the state, a legally mandated autonomy involving rights guaranteed by the state. According to a liberal definition, civil society is not necessarily in opposition to the state. From a Gramscian perspective, civil society is seen as a sphere of resistance. Diamond also states that democracy is strengthened by civil society's acts of 'containing the power of the state through public scrutiny' (Diamond and Plattner 1993: 8). In 'Third World' contexts, it is also debatable whether civil society could also encompass patron--client relations, tribal systems, ethnicities, and so on. The general literature on processes of democratization in the Middle East deals primarily with the Arab state system (Salamé 1994; Ayubi 1995). The many authoritarian states in the region have been challenged by civil society, which regards itself as the guarantor of at least some sort of scrutiny of the states. Even less researched is the issue of regional governance and the role played by civil society within it.

Some researchers include political parties as part of civil society (Ibrahim 1995: 28; Moussali 1995: 52); others claim, however, that parties are linked to the state structure (Cohen and Arato 1997: 350). However, most authors underline the fact that civil society belongs to the public sphere and not to the private one. There is consent in the majority of studies that the term does not include the financial sphere, which is made up of private, profit-making companies and financial corporations. Another unresolved issue is whether civil society refers to organizations with voluntary association only, or whether patron-client relations, extended families, tribes and ethnicities are part of civil society as, in fact, the initial definition might suggest. In this chapter these are seen as part of civil society, since they are often described as being neither state nor market actors, but as playing an important role, not least in terms of personal security, within Middle Eastern societies. Although the borders between the various spheres are often analytically blurred, the informal structures of civil society constitute a sphere between the population/citizens in a society, and government structures. Hence, a distinction between formal and informal sectors of civil society can be made.

Further, it is often assumed from a liberal point of view that civil society refers to values, such as civility, implying tolerance, pluralism, 'a cast of mind, a willingness to live and let live' (Norton 1995: 12). However, this amounts to a romanticized and idealistic perception. Civil society might also breed prejudice and hatred, and therefore is not regarded in this chapter as being inherently societally benign, despite the fact that Middle Eastern citizens often trust civil society more then they trust government structures. Rothstein $(2001,2000)$ emphasizes the importance of the socialization process: our perceptions and norms in relation to our societal institutions begin to be formed when we are small children. From our parents' stories and the social environment, perceptions and collective memories of whom to trust are internalized. Hence, in the Middle East one might expect citizens within historically authoritarian structures to develop their trust and values from such informal processes. This does not, however, imply that civil society is always a counterforce to governmental 
structures (Cohen and Arato 1997; Ibrahim 1995: 28-29; Moussali 1995: 81; Norton 1995: 1-11). In essence, the actions of a particular sector of civil society can only be judged through empirical investigation.

\section{Previous research}

Can one study a phenomenon that does not exist? The question is justified since Middle East regionalism is an embryonic process. From a comparative perspective the Middle East is one of the least regionalized regions in the world (see Schulz et al. 2001; Harders and Legrenzi 2008). One might even expect regional governance and civil society in the Middle East to be close to non-existent. In contrast, this chapter argues that civil society is increasingly, though slowly and gradually playing an influential role as an agenda setter in regional governance. Previous studies have not focused on this aspect, although civil society and its role within the Middle East state system have been discussed. For the most part, civil society has been discussed in relation to democratization within the states in the region. This is an important debate, since civil society's space for manoeuvre and capacity are restricted to a large extent by the state. This is not to say that civil society cannot exist within an authoritarian structure; however, its capacity to influence and engender change is thereby compromised (Sariologhalam 1997).

Democratization in the Middle East has been on the agenda since the 1990s and civil society has often been seen as its forerunner. What role does civil society play in Middle East democratization? The Middle East is usually seen as a region where democratization has not occurred (Salamé 1994). In general, it is often stated that the Middle East is something of a 'lost cause' (Deegan 1993: 8-9). Arguments in previous research usually relate to the specific characteristics of the region, where states are: 'weak institutionally; divided ethnically; tethered to authoritarian structures of government; lacking in unity, political legitimacy and tolerance of opposition; exploited by the external factor of the Cold War and recently, in thrall to fundamentalist religion' (Deegan 1993: 8-9).

All in all, these factors are regarded as serious obstacles to any form of democratization, now or in the future. However, it has been shown that at the national level civil society has played an immensely important role in terms of democratization from below. For instance, in the Palestinian case, it is claimed that a strong and viable civil society has been one of the few institutions that has functioned during the Israeli occupation, and continued to play a scrutinizing role vis-à-vis the Arafat-led Palestinian Authority established in 1993/94 (see Schulz 2003). In Egypt, Algeria and Morocco, for instance, civil society pushes the state to address human rights. From above, gradual changes have followed in states such as Jordan and Egypt, in which semi-open elections have taken place after pressure from, among others, civil society organizations. Thus, state elites often open up to democratic practice in reaction to the requests of civil society actors.

Increased awareness of this small but growing civil society in the Middle East also contributes to regional networking, fostering new cooperation, and also creating a more vivid debate around the issue of democracy. Globalization itself 
further increases awareness and stimulates the growth of networks with actors external to the Middle East. This in itself further strengthens the chances for establishing and consolidating a vivid and democratic regional debate across the states. Hence, we need to understand more about the strength of civil society in the region.

Although definitely a late-comer, the Middle East has entered the debate on global democratization, although many have argued (from different positions) that the area is an exception to this trend (for example, Salamé 1994), in the sense that traditional kingdoms or security-dominated regimes still cling to power and the strongest force of opposition (namely Islamism) does not have democracy on its agenda. In one of the most oft-quoted works (Diamond et al. 1989) on the 'third wave of democratization' (Huntington 1991), it is argued that the Arab states 'generally lack previous democratic experience and most appear to have little prospect of transition even to semi-democracy' (Diamond et al. 1989). According to Vanhanen's index on democracy for states recoded into a regional democracy index, the Middle East scored 2.70 in 1980 and 3.69 in 1988 (Vanhanen 1990: 27). According to Vanhanen, a state is considered democratic when it reaches 5.00 or above on the index. In comparison to South America, which scored 5.56 in 1980 and 14.67 in 1988, there is a vast discrepancy in both the speed and level of democratization. Although his database has not been applied to the current time period, other data, such as the Freedom House index, confirm that his data are still relevant. Middle East alleged 'exceptionalism' is 'explained' by a variety of variables, depending on the author. Orientalists still point to the broad and oversimplified category of 'culture' and Islam (for example, Kedourie 1992). Others hold that nation-building projects have failed and that loyalties are mainly sub-national and horizontal, preventing national democracy from taking root; the state as such is imposed by external actors and is thus floating, void of meaningful relations to its citizens (Alavi 1979). The existence of 'rentier economies' (Luciani 1990; Brynen 1992) and the weak taxation system are other factors, as is the fluid class structure and interdependence between the enlarged intermediate strata in the form of state bureaucracy and the regimes (Ayubi 1995). Lastly, conflicts and wars have paved the way for militarized states to legitimize themselves through 'missions', such as the struggle against imperialism, for Arab unity, and for the liberation of Palestine, rather than through rule by the people. A historical and structural approach would look, rather, at the processes and patterns of state formation since independence as well as the role of classes. From the outset then, the Middle East does not seem to have many prerequisites for true democratization.

In spite of these assertions, in recent years Jordan, Algeria, Tunisia, Morocco, Egypt, Yemen, Lebanon and the Palestinian self-ruling areas have entered into different experiments with electoral practices, thus paving the way for discussions about the potential for the democratization of Arab political systems. The end of the Cold War, the Gulf War and the decline of the Arab-Israeli conflict have induced political change. This process is sometimes called 'formal democratization' (Ayubi 1995: 396), 'facade democracy' or instrumentalism accompanying structural adjustment programmes. In that sense, they provide some 
evidence for the argument that the trend towards political liberalization is merely a response to pressures from global capitalism. Whatever the causes, and however cosmetic, there is today obviously a need for Arab regimes to bring the concept of democracy into their political discourse. There is then also currently a need to look into the sphere of non-state actors in order to investigate prospects of further political liberalization. As is argued by many authors (for example, Norton 1995; Dryzek 1996), changes towards democratization are often initiated by actors in civil society: '[P]ressures for greater democracy almost always emanate from oppositional civil society, rarely or never from the state itself' (Dryzek 1996: 476).

Some analysts would claim that democratization by Islamists and Islamic civil society is not possible since Islam is inherently incompatible with democracy (cf. Sørensen 1993; Huntington 1993; Tibi 1998; Kramer 2001; Spencer 2005). For example, Spencer claims that in Islamic law, all non-Muslims have an inferior position vis-à-vis Muslims. Another argument put forward is that Islam constitutes a threat to the basic values of the West, including its democratic mode of governance. Others (Esposito and Voll 1996; Midlarsky 1998) claim that the democratic structures of Islamic organizations come from the grassroots level. Furthermore, and in contrast to their regimes, democratic popular political culture is strong all over the region (Goddard 2002; Tessler 2002; Inglehart 2004). Most studies relate to Islamist movements or parties outside the government (Norton 1995; Özdalga and Persson 1997); to cases outside the Arab world, such as Iran (Ansari 2000) or Turkey (Özdalga 1998; Liel 2003); or to the failed attempts in the Arab world (not least Algeria). It is rare to see connections in this kind of analysis, which would suggest that the political behaviour of Islamist parties/movements could be explained through an analysis of political culture (see Tessler 2002) and in relation to regional governance.

Finally, one should not underestimate the impact of external influences on both the state structures and the civil society sectors in the Middle East. The US takeover of Iraq in 2003, as a result of which democracy has been partly imposed, has also had an overall impact in the Middle East, in so far as debates occur regarding different strategies and ideas on how to democratize. Not surprisingly, particularly among Islamist groups that are critical of the US democracy strategy in the Middle East, a vivid debate on democracy is taking place. Islamists have their own debate on how Islam and democracy are linked, and how best practices can be developed.

\section{Middle Eastern regionalism and transnationalism}

Middle Eastern regionalism has been described at best as cooperation, and more often as competition rather than integration. Several experiments of a regional character have been tried out; however, a genuine regional project has not yet been realized. Many projects are sub-regional, such as the Gulf Cooperation Council (GCC) and the Arab Maghreb Union (AMU). The better-known regional 
organizations that include countries from the Middle East are the Arab League (excluding Iran, Israel and Turkey), the Organization of the Islamic Conference (including non-Middle East states), the Greater Arab Free Trade Area and the Mediterranean Arab Free Trade Agreement (the two latter excluding Iran, Israel and Turkey). Also, the oil-producing organizations such as the OPEC (including many non-Middle Eastern states such as Nigeria and Venezuela) and the OAPEC (excluding non-Arab members of the Middle East) can be seen as partly regional projects. In addition, inter-regional arrangements have been discussed and developed between the EU (in the framework of its neighbourhood strategy) and parts of the Arab world. These regional projects were launched in 1995 under the umbrella of the so-called Barcelona process. What is common to all these projects is that they are formal and deeply state-driven (and partly marketdriven) (see Lindholm Schulz and Schulz 1998; 2005).

In line with Lawson (2008), one has to differentiate between regionalist projects along four dimensions: the degree to which regional institutions have the authority to formulate and implement policy with regard to important issue areas, independently of the member states concerned; the rules that govern decision making in such regional institutions; the extent to which regional formations have the capacity to provide incentives to induce member states to comply with programmes that further the interest of the region as a whole; and the degree to which regional institutions and agencies provide a foundation for heightened economic interdependence among member states (Lawson 2008: 22). Middle East regional projects have scored low on all four dimensions. No real regional governance capacity exists in the contemporary regional formations. For instance, Saudi Arabia can block any decisions within the GCC decision-making institutions if they are not in its national interest. Further, the oil-producing countries in the Arab world have had difficulties in creating incentives for economic interdependence due to their highly globalized petrodollar industries. Competition rather than cooperation is the basis for their relations. Hence, although embryonic and weak, pressure for change comes from below, and inside the states themselves.

\section{Civil society in the Middle East}

Civil society in the Middle East is not as strong and vivid as in other parts of the world. Further, the strong internal security apparatus, the Mukhabarat, in the Arab states, often controls the activities of civil society, thereby severely limiting its capacity to act freely. In Egypt, for instance, all new non-governmental organizations (NGOs) have to register and receive the permission of the state to operate. Historically, one can identify four major trends in the development of civil society in the region. First, the period before the arrival of the European colonial powers when civil society mainly consisted of 'community based self help groups, guilds, and religiously oriented charity and educational institutions, these last funded by Islamic endowments known as waafs (plural awqaf)' (Hawthorne 2005: 84). The second period when civil society developed came with the arrival of the colonial powers. Professional organizations, trade unions, cultural 
clubs and Islamic organizations came into existence, not least the Muslim Brotherhood. Characteristic of these forms of civil society was that they both supported the idea of pan-Arabism but simultaneously had very particular national orientations. In the third phase, civil society came under Arab state control, since these regimes feared challenges from a free civil society. After years of repression civil society saw new ways to develop when the Arab states opened up, very much under the impact of globalization, liberalized their societies gradually, and gave way to a freer civil society (Hawthorne 2005). Civil society in Turkey and Iran followed much the same pattern as the Arab states. Israel's pattern is more similar to the Western world; for instance, the Israeli trade union Histadrut had a very influential position in national society, although it became gradually weaker from the 1980s following set-backs for leftist governments, and as a result of the liberalization of the Israeli economy.

The five sectors of Middle Eastern civil society are Islamist associations and organizations, non-governmental service organizations, professional organizations, companionship and solidarity NGOs, and pro-democracy associations. The prodemocracy sector is the youngest and smallest, while the Islamist associations and organizations comprise the biggest and most influential sector (Hawthorne 2005). These different sectors are unequally distributed in the region, and have very different options for action within their societies. In Syria, Libya and some of the Gulf states, civil society has very restricted space for manoeuvre, or is even regarded by the state as illegal. In Oman, Qatar, Saudi Arabia and the United Arab Emirates various forms of Islamic charity organizations have been able to gain a semi-accepted status. In Algeria, Bahrain, Egypt, Jordan, Kuwait, Tunisia and Yemen, civil society has been relatively vivid and part of the societal debate. In these states, there has been far less repression and fewer restrictions on civil society. In the 1950s and 1960s various professional organizations and trade unions had significant influence but the Islamist associations have become the most important part of today's civil society, and have taken over many important service sectors. These sectors are financed mainly by the Islamic zakat, or partly by donations from foreign governments. Besides Israeli civil society, Arab civil society in Lebanon, Morocco and the Palestinian territories has been the freest and most influential. In fact, before the Declaration of Principle between the Palestine Liberation Organization (PLO) and Israel in 1993, civil society institutions in the West Bank and the Gaza Strip were the only bodies able to provide services to the Palestinian people. Still, Palestinian civil society involves hardly more than 10 per cent of the population. (Hawthorne 2005; Schulz 2003). These various developments and different sectors of civil society in the region have contributed to transnational cooperation. The issues at stake are to what extent they have contributed to form a regional governance capacity, and in what areas.

\section{Civil society in regional governance in the Middle East}

Can we talk about civil society when Middle East regional governance can hardly be claimed to exist? It is important to underline the fact that the civil 
society activities and networking that are taking place across the countries in the region constitute de facto an informal regionalization project from below. As has been explained elsewhere, regionalization can take place in various forms, from above and/or from below, and by different state, market and civil society actors (see Schulz et al. 2001).

NGOs that deal with issues that are similar for the entire region have indirectly contributed to 'regionalizing' issues that still mainly receive national attention. For instance, issues such as severe human rights violations in the authoritarian states, HIV/AIDS issues that have been defined as taboos in many Arab states, or gender and development issues have all been addressed and brought to the regional agenda by civil societies networking. Civil society also works to lobby organizations such as the Arab League and the Islamic Conference. In addition, with the creation of new TV stations such as al-Jazeera, a regional news consciousness is being developed by the media in the Arabspeaking Middle East.

\section{Civil society as agenda setter of regional issues}

Historically, and apart from general pan-Arab ideologies, the Palestine question has been the one issue that has helped to unite the Arab world. But it has also helped to split the region, since it naturally excluded Israel from the Arab world. However, Arab nationalism also came to exclude Iran and Turkey. Although pan-Arabism lost its attraction among Arab leaders, particularly after the failed Arab union between Egypt and Syria (1958-62) and Iraq-Jordan union (in 1958), the masses of many Arab states still have a sense of belonging to an Arab 'imagined community' (Anderson 1991). Hence, civil society organization is also identified with Arab identity, as well as with the Palestinian issue.

The Palestinian issue has been on the formal regional agenda since the Arab League was founded in 1945. The Arab League was in fact formed as a reaction against Western colonialism, as well as against the Zionist movement's attempt to create a Jewish state in Palestine. Support for Palestinian statehood has also been addressed in strong terms by various civil society organizations in the Middle East. In more recent times we can see how civil society has protested against Israeli military actions in the self-rule areas, as well as against Palestinian positions in other parts of the Middle East. For instance, when Hezbollah and Israel had their war of summer 2006, a war that severely hit Lebanon, civil society was deeply involved in various ways (organizing psychological help for those who had suffered traumas, helping those in need of food, shelter and so on). However, one could argue that these issues of pan-Arabism and the Palestine question are linked to what used to be labelled 'old regionalism', excluding non-Arab actors in the regional awareness of the Middle East. During the heyday of the Oslo peace process between Israel and the PLO (1991/93-2000), many NGOs contributed to redefining the future Middle Eastern map. All of a sudden Israel was a potential partner in the region. The multilateral tracks of the so-called Madrid conferences that started in 1991 led to participation by the 
business and investor worlds as well as by NGOs, and a regional awareness took form. In these multilateral talks, issues like refugees, environmental problems, weapons of mass destruction, water and refugees were on the agenda. The Israel-Palestine Peace NGO Forum and Alliance for Middle East Peace, for example, are umbrella organizations that are setting new agendas outside Israel and the Palestinian areas in the search for potential new peace ideas and alternatives.

In the last decade, however, new issues such as climate change, water and HIV/AIDS have been identified as problems transcending the boundaries of the traditional nation-state. Civil society in the Middle East has not only taken part in agenda setting but has even been its key driving force. For instance, the Arab Climate Network formed in 2005, and the Arab Climate Alliance formed in 2008, are attempts by the NGO sector to unite and bring climate issues onto regional agendas such as the Arab League's. The League immediately subscribed to the Kyoto agreement and called on Arab states to take part in that agreement. Hence, civil society contributes to setting the agenda, and influences leaders in the region to take the view that regional issues need common regional agreements and policies. The organization Arab Integrated Water Resources Management Network (AWARENET) comprises research institutes, NGOs and government experts within a regional frame. It helps the public by providing them with water resources. It exists in 18 different Arab countries. States such as Iraq, Syria and Turkey have always seen water as a national security issue, but, AWARENET focuses on water as a regional concern, and emphasizes the need to look at the problem from grassroots perspectives and create a participatory bottom-up process. It also works closely with different United Nations (UN) organs.

Further, HIV/AIDS has always been a taboo issue in the Middle East. Governments have had an attitude of avoidance, often downplaying the problem by underestimating the real figures, even though these are lower than in other regions. Iran, Israel and Turkey have a relatively well- developed system of registering HIV/AIDS cases, but any such system is still underdeveloped in the Arab world. NGOs like the Red Crescent and prison organizations work with UN branches to develop increased awareness, as well as to push regional organizations to develop a common plan. The Arab League has been forced to act on the issue. Hence, despite the fact that HIV/AIDS is still downplayed in the Arab world, civil society has contributed to debates to launch a new health system, and fundamentally to increase awareness of the illness itself, and thereby break taboos.

\section{Civil society as regional social security provider}

Civil society organizations have for a long time taken care of social issues, such as education, health care and sports activities, for the weakest sectors of society. However, the tremendous development problems due to poverty and educational needs in societies undergoing rapid demographic change create huge challenges. 
These have come increasingly to be regarded as common to many Middle Eastern societies. Civil society has become a social security provider for many societies in the region. The state and public institutions are generally less trusted and less able to deliver the social welfare that is needed. Hence, civil society and NGOs constitute the real support system, apart from traditional clan and family systems that provide social security for individuals.

More recently regional networks and NGOs have been formed with the aim of tackling development issues. For instance, the Arab NGOs Network for Development (ANND) that was formed in 1996 has a mission to strengthen the role of civil society. It works in 12 different countries, and aims to enable the NGO sector to work more freely and with less government control, and to provide the social welfare that the state cannot handle. It operates through networking, campaigning, research, lobbying, media and communication, capacity building and active participation in global, regional and national meetings and conferences. ANND works with three overarching themes linked to development, democracy and trade. Hence, coordination among NGOs across the Arab states increases pressure from below on the states' leaders as well as regional organizations. Typical of these regional umbrella networks is that they work closely with international non-governmental organizations (INGOs), as well as with global institutions and donors (the UN, the World Health Organization, the World Bank, and so on). Thus, they are also influenced to a significant extent by issues that are important in the West, not least concerning democracy and human rights. In the context of the 'war on terror' after 11 September 2001, many civil society organizations in the Middle East began to form advocacy organizations for democracy. Several regional NGOs such as the Arab Centre for the Independence of the Judiciary and the Legal Profession, the Arab Commission for Human Rights and the Arab Organization for Human Rights are examples of regional NGOs working on human rights for individuals and freedoms in the Arab states. Some have a more focused target, such as the Centre for Media Freedom which mainly works on press and media freedom, or Habitat International Coalition - Housing and Land Rights Network which works with land and justice issues in the Palestinian context but also with minorities and tribes in different Arab states. NGOs, such as the Gay and Lesbian Arab Society, also work on sexual minority issues that are taboo in most of the Middle East. Most NGOs have a national focus, but constantly search for similar organizations in the region in order to strengthen their advocacy capacity, and to raise key issues in regional and international arenas.

This category of regional NGO networks is characterized as being highly globalized, and often secular, or with a non-religious approach. They usually have close connections and relations with INGOs, in the sense that they collaborate, and apply jointly for funds from mainly Western and Japanese donors. They are often accused of being donor- driven, following a too Western approach, with little relevance to the regional needs of the Middle East. Although justifiable criticisms have been made (see Ritchmond 2005; Duffield 2001), it is also the case that some of the critiques have come from authoritarian regimes, or from 
Islamist associations that perceive many of these NGOs as being corrupted by Western ideas and money, imposing non-religious, non-Islamic, thoughts on the public. At the same time, analysts have often seen them as the drivers of democracy in the Middle East (Norton 1995). As mentioned above, it is also the case that many of these national and regional NGOs have been important advocates for promoting democracy. However, there are still relatively few of these types of NGOs and they often have little strength. Paradoxically, the most critical sectors of Middle Eastern societies against secular NGOs come from within Islamic civil society.

Islamic civil society movements and organizations are keen to work with Islamic religious representatives on social and developmental issues. Analysts have made the mistake of underestimating their role in the democratization of Arab states. Kramer (2001) would even go as far as to say that analysts have put forward too romantic a view of civil societies' capacity, and that describing Islamist associations as democratic underestimates the violent and terrorist activities of some of these groups. However, the Islamist associations have very different approaches to the social issues they deal with, not least democracy. For example, all decisions take in the Iranian Islamic Republic (by the President, parliament and so on) have first to be approved by the Shiia clerics. This is in fundamental contrast to how Hamas perceives that democracy should be run. Hamas underlines the fact that concentration of power is not their preference; on the contrary, a division of powers is necessary for a healthy and democratic society. The executive, juridical and legislative powers are tools for implementing the rule of law, democracy and reforms that can serve the people. Hamas strongly dismisses the Iranian system of Sharia rule (Gunning 2008; Schulz 2009).

Despite these differences, Islamic civil society contributes to resistance against the authoritarian and often secular regimes in the Middle East (Crooke 2009). Hence, links between them contribute to raising development issues, the lack of democracy, abuses of human rights, and religious issues at the regional level. Further, in contrast to many secular NGOs, these Islamic organizations and movements have strong popular support. The legitimacy they derive from the public therefore constitutes strong opposition to the repressive states in the Middle East. The form of social infrastructure and networking established by Islamist organizations might themselves serve as a catalyst for increased participatory politics. Islamic institution-building and networking in the form of schools, mosques, health clinics, kindergartens and so on represent a form of mobilization from below, although there are also instrumentalist political reasons behind this. Hence, Islamist NGOs and movements can contribute to placing regional issues on the agenda and also to creating a new regional dynamic to challenge traditional state structures. These movements may be Hezbollah in Lebanon, the Muslim Brotherhood in Egypt and Jordan, Islamist groups in Iraq, or Hamas in the Palestinian areas, and many more. Although very different in their settings, they all represent regional resistance and challenge the deficits in democracy and the development problems in the existing state structures. The challenge for Middle East states, as well as the West, is to create a dialogue and 
ensure that they stay on the road to pragmatism and reform instead of violent resistance and terror.

\section{Conclusion}

Civil society in the Middle East is weak in comparison with many other parts of the world. At the same time, despite its relative size, analysts have high hopes that it can be a driving force in various areas, such as democratization, development and, not least, regionalization, bringing positive change to the otherwise Westphalian Middle East system. This chapter has shown that civil society has been active in several key areas related to social welfare, development, peace and security, democracy and human rights, as well as resources and climate change. Many studies have shown that it has been an initiator, agenda setter and advocate for these issues, and hence has put pressure on those weak states that have failed to meet the needs of their populations. This chapter has attempted to show some of the important activities that are taking place across the state system of the Middle East. Regional integration in the Middle East is at best embryonic in comparison with other parts of the world. There is no determinism in claiming that Middle East civil society, with all its various different sectors, is de facto transcending the state system and becoming regionalized. However, it is clear that its contribution must be further analysed, since it contributes de facto to challenging the many authoritarian states in the region. Thus, it contributes to a transnational identification process, and thereby creates an awareness of issues such as democracy, development and human rights in the region. In turn, this fosters new networks and cooperation at the regional level. Hence, civil society organizations frame issues as regional governance needs, but also build cooperation across state borders, strengthen civil society and advance the issues they advocate vis-à-vis the many authoritarian regimes in the region. Pressure for change, such as democratization, cannot be completely ignored within one state, since the increasing number of transnational civil society organizations and their networks can continue to advocate and lobby for change.

This chapter concludes that civil society is an initiator, agenda setter and advocate of regional governance, and is lobbying from below. Regionalization in the Middle East is embryonic and a social project still coming into being. It is an empirical question for the future to decide whether civil society, besides initiating a regional debate, can also constitute the first building blocks for continued regionalization. In such a process, current embryonic tendencies will be strengthened and have a direct impact on democratization in the region, but will also influence other areas such as development, education and health. In addition, is the civil society networking that is criss-crossing the entire region a social power, questioning rigid state realism from below, and thereby implicitly creating a common imagined regional identification? The answer lies in the future and partly in the strength Middle East regional organizations develop. One crucial future research task therefore is to assess the strength of civil society if it continues to push for regional governance capacities in the Middle East. 


\section{References}

Alavi, H. (1979) 'The State in Post-Colonial Societies: Pakistan and Bangladesh', in H. Goldbourne (ed.) Politics and the Third World, London: Macmillan, pp. 38-69.

Anderson, B. (1991) Imagined Communities, London: Verso.

Ansari, A. M. (2000) Iran, Islam and Democracy. The Politics of Managing Change, London: Chatham House.

Ayubi, N. N. (1995) Overstating the Arab State, I. B. Tauris.

Brynen, R. (1992) 'Post-Rentier Democratization in the Arab World: The Case of Jordan', Canadian Journal of Political Science, 25(1): 69-97.

Cohen, J. L. and Arato, A. (1997) Civil Society and Political Theory, Cambridge, Mass., and London: The MIT Press.

Crooke, A. (2009) Resistance. The Essence of the Islamist Revolution, London: Pluto Press.

Deegan, H. (1993) The Middle East and Problems of Democracy, Buckingham and Philadelphia, Pa.: Open University Press.

Diamond, L. and Plattner, M. F. (eds) (1993) The Global Resurgence of Democracy, Baltimore, Md., and London: The Johns Hopkins University Press.

Diamond, L, Linz, J. J. and Lipset, S. M. (1989) Politics in Developing Countries. Comparing Experiences with Democracy, Boulder, Colo., and London: Lynne Rienner.

Dryzek, J. S. (1996) 'Political Inclusion and the Dynamics of Democratization', American Political Science Review, 90(3): 475-497.

Duffield, M. (2001) Global Governance and the New Wars. The Merging of Development and Security, London and New York: Zed Books.

Esposito, J. and Voll, J. (1996) Islam and Democracy, Oxford: Oxford University Press.

Goddard, H. (2002) 'Islam and Democracy', Political Studies Quarterly, 73(1): 3-9.

Gunning, J. (2008) Hamas in Politics. Democracy, Religion, Violence, London: Hurst.

Harders, C. and Legrenzi, M. (eds) (2008) Beyond Regionalism? Regional Cooperation, Regionalism and Regionalization in the Middle East, Aldershot and Burlington, Vt.: Ashgate.

Hawthorne, A. (2005) 'Is Civil Society the Answer?', in T. Carothers and M. Ottaway (eds) Uncharted Journey. Promoting Democracy in the Middle East, Washington, DC: Carnegie Endowment for International Peace, pp. 57-80.

Huntington, S. P. (1991) The Third Way. Democratization in the Late Twentieth Century, Norman: University of Oklahoma Press.

(1993) 'Clashes of Civilizations', Foreign Affairs, 72(3): 22-50.

Ibrahim, S. E. (1995) 'Civil Society and Prospects of Democratization in the Arab World', in R. A. Norton (ed.) Civil Society in the Middle East, Volume I, Leiden, New York and Cologne: E. J. Brill, pp. 27-54.

Inglehart, R. (2004) Islam, Gender, Culture and Democracy: Findings from the Values Surveys, Willowdale, Ont.: de Sitter Publications.

Karam, A. M. (1997) Women, Islamisms and the State: Contemporary Feminisms in Egypt, London: Palgrave Macmillan.

Kedourie, E. (1992) Democracy and Arab Political Culture, Washington, DC: The Washington Institute for Near East Policy.

Kramer, M. (2001) Ivory Towers on Sand. The Failure of Middle Eastern Studies in America, Washington, DC: The Washington Institute for Near East Policy.

Lawson, F. H. (2008) 'Comparing Regionalist Projects in the Middle East and Elsewhere: 
One Step Back, Two Steps Forward', in C. Harders and M. Legrenzi (eds) Beyond Regionalism? Regional Cooperation, Regionalism and Regionalization in the Middle East, Aldershot and Burlington, Vt.: Ashgate, pp. 13-32.

Liel, A. (2003) Demo - Islam, Jerusalem: Rubin Mass.

Lindholm Schulz, H. and Schulz, M. (1998) 'The Middle East as an Exception or Embryonic Regionalism?', Politeia, 3: 95-111.

Lindholm Schulz, H. and Schulz, M. (2005) 'The Middle East: Regional Instability and Fragmentation', in M. Farell, B. Hettne and L. Van Langenhove (eds) Global Politics of Regionalism. Theory and Practice, London and Ann Arbor, Mich.: Pluto Press, pp. 187-201.

Luciani, G. (ed.) (1990) The Arab State, London: Routledge.

Midlarsky, M. I. (1998) 'Democracy and Islam: Implications for Civilizational Conflict and the Democratic Peace', International Studies Quarterly, 42: 458-511.

Moussali, A. S. (1995) 'Modern Islamic Fundamentalist Discourses on Civil Society, Pluralism and Democracy', in R. A. Norton (ed.) Civil Society in the Middle East, Volume I, Leiden, New York and Cologne: E. J. Brill, pp. 55-62.

Norton, A. R. (ed.) (1995) Civil Society in the Middle East, Volumes 1 and 2, Leiden, New York and Cologne: E. J. Brill.

Özdalga, E. (1998) The Veiling Issue: Official Secularism and Popular Islam in Modern Turkey, Richmond, Surrey: Curzon.

Özdalga, E. and Persson, S. (eds) (1997) Civil Society Democracy and the Muslim World, London: Curzon Press.

Ritchmond, O. P. (2005) The Transformation of Peace, New York: Palgrave Macmillan.

Rothstein, B. (2000) 'Trust, Social Dilemmas and Collective Memories', Journal of Theoretical Politics, 12(4): 477-501.

- (2001) 'Social Capital in the Social Democratic Welfare State', Politics and Society, 29(2): 206-240.

Saikal, A. and Schnabel, A. (2003) Democratization in the Middle East. Experiences, Struggles, Challenges, Tokyo, New York and Paris: United Nations University Press.

Salamé, G. (ed.) (1994) Democracy Without Democrats? The Renewal of Politics in the Muslim World, London and New York: I. B. Tauris.

Sariologhalam, M. (1997) 'Prospects for Civil Society in the Middle East: An Analysis of Cultural Impediments', in E. Özdalga and S. Persson (eds) Civil Society Democracy and the Muslim World, London: Curzon Press, pp. 55-62.

Schulz, M. (ed.) (2003; 2nd edn 2006) Democratization and Civil Society in the Middle East: Case Studies of Palestinian Self-Rule Areas and Iraqi Kurdistan, Stockholm: Sida and Göteborg University: Centre for Middle East Studies.

- (2009) 'The Role of Hamas in Building Democracy in the Midst of Violence', in A. Swain, R. Amer and J. Öjendal (eds) The Democratization Process: Opportunities and Challenges, London: Anthem Press, pp. 113-133.

Schulz, M., Söderbaum, F. and Öjendal, J. (eds) (2001) Regionalization in the Post-Cold Era, London: Zed Books.

Sørensen, G. (1993) Democracy and Democratization, Boulder, Colo.: Westview Press.

Spencer, R. (2005) The Myth of Islamic Tolerance. How Islamic Tolerance Treats NonMuslims, Amherst, Mass., and New York: Prometheus Books.

Tessler, M. (2002) 'Islam and Democracy in the Middle East: The Impact of Religious 


\section{M. Schulz}

Orientations on Attitudes toward Democracy in Four Arab Countries', Journal of Comparative Politics, 34 (April): 337-354.

Tibi, B. (1998) The Challenge of Fundamentalism: Political Islam and the New World Disorder, Berkeley, Calif.: University of California Press.

Vanhanen, T. (1990) The Process of Democratization. A Comparative Study of 147 States, 1980-1988, New York: Taylor \& Francis. 


\title{
10 Transnational labour mobilization in the Americas
}

\author{
Marcelo Saguier
}

\section{Introduction $^{1}$}

Processes of globalization and regionalization are transforming the dynamics of mobilization and rights-demanding practices of the labour movement. The transnational organization of production and capital mobility pose great challenges to the international labour movement. The rising pressure of competition between national and regional economies is driving labour conditions and wages down, introducing regulatory competition between weakening national labour regimes and threatening the bargaining power of the labour movement (Eder 2002; van Liemt 1999: 113). While competition with cheap labour has been a key concern of workers in the industrialized North, it has also become a crucial feature of South-South relations since the rise of China and India as emerging economies in receipt of foreign direct investment (FDI) (Ross and Chan 2002). Other changes in the labour market include increased informality, flexibility, outsourcing, the deterioration of the quality of work, and legal and illegal migration. All this undermines the capacity of trade unions to represent the rights of workers.

Trade policy in particular becomes a key site of engagement for the labour movement in the context of a globalizing/regionalizing political economy. The opportunities for trade unions to participate in trade processes are significantly affected by the 'forum shift' tactics used by powerful states and corporations. Forum shifting means moving between decision arenas in order to secure the desired outcomes in the places where this is expected to be more likely. When multilateral (World Trade Organization, WTO) and regional (Free Trade Area of the Americas, FTAA) trade negotiations break down, the liberalization agenda is often pursued bilaterally - as in the Free Trade Agreements (FTAs) promoted by the US government and the Economic Partnership Agreements (EPAs) sponsored by the EU. This compromises the trade unions' efforts to influence the processes of trade policy making.

Forum shifting demands that trade unions mobilize across various institutional and geographical sites. Forum shifting in trade negotiations renders obsolete those labour tactics centred exclusively on the nation-state (Appelbaum 2005: 371; Harrod and O'Brien 2002; Mazur 2000). It then becomes crucial to combine national and transnational scales of action (Herod 2002: 83; Stevis 
2002: 130). In the twenty-first century trade unionism 'has to be local, national and international at one and the same time' (Hyman 2004: 27). Some unions are beginning to adopt new dynamics of mobilization by creating flexible multisectoral networks and transborder alliances to take part in global campaigns and lobbying practices in international governance institutions (Harrod and O'Brien 2002; O'Brien et al. 2000; Waterman 2001). More than ever, the renewal of a critical labour movement is tied to its ability to mobilize at multiple decisionmaking levels, articulating transnational strategies directed at the institutional, material and ideational power structures of neoliberal globalization.

This chapter examines the dynamics of mobilization and rights-demanding practices of the labour movement in the Western Hemisphere, as evidenced in its coordinated response to the FTAA process. In many ways the labour responses to this trade project reveal the opportunities and challenges faced by the international labour movement in its efforts to reinvent itself in a context of transnational production and increased corporate power.

The project to create an FTAA was originally announced in 1994 by 34 states in the Western Hemisphere. Negotiations began in 1998, but they were never completed, due to a lack of governmental consensus over the agenda, as well as the hard opposition mobilized continentally by many social movements, which denounced the undemocratic and socially regressive implications of this trade project. The FTAA proposed to introduce a form of 'new constitutionalism' (Gill 2002), a system of regional economic governance to lock in liberalization reforms undertaken during the 1990s, and to extend property rights in areas previously excluded from liberalization and rule-bound commitments (services, investment rules, intellectual property rights, government procurements and competition policy). This trade agenda has serious implications for sustainable development and democracy (Anderson and Arruda 2002; Barenberg and Evans 2004; Estay and Sánchez 2005; Hillebrand 2003; Icaza et al. 2010; Sangmeister and Taalouch 2003). It prompted a response from many labour organizations throughout the region, which first sought to include a labour agenda in the trade agreement, and later decided to try to halt it altogether once it became evident that the FTAA was incompatible with sustainable development. In 2005 the FTAA process reached a final standstill after years of stagnated negotiations.

It is argued that the dynamics of labour mobilization around the FTAA process manifests new trajectories in the renewal of the hemispheric labour movement. While some of these dynamics can be attributed to labour strategies that predate the FTAA process, others are the result of specific struggles to prevent the deepening of a neoliberal approach to integration captured in the FTAA project. In this regard, labour's engagement with the FTAA process can be understood as a path-dependent process contributing to the exploration of new opportunities for mobilization. This chapter identifies four distinct labour practices that demonstrate a transformation in the movement's dynamics of mobilization.

The first section concentrates on the practices of engagement of a group of leading trade union organizations in the formal FTAA negotiations. It discusses 
the extent to which trade unions were able to open the negotiations to include a social perspective in the agenda-setting process of the FTAA. The second section deals with the initiatives taken to unite politically and organizationally the various factions of trade union organizations into a single hemispheric movement. Some of the North-South tensions of alliance building across national and regional scales are addressed. Moreover, the third section covers the practices of coalition building between labour organizations and social movements. It explores the extent to which such multi-sectoral coalitions redefine the basis of 'representation' of the labour movement, by incorporating a broader range of social demands that were not traditionally covered by a labour movement centred on urban/industrial employment issues. Finally, the fourth section deals with the participation of the labour movement in the creation of informal political spaces at the grassroots levels to mobilize popular support against the exclusionary impacts of the FTAA.

\section{Engagement in trade negotiation processes}

The FTAA process has been criticized for its 'democratic deficit' by many social movements in the region that pursued different initiatives to democratize this and other trade processes implemented since the 1990s (Icaza Garza et al. 2009). The labour movement in particular played a leading role in the efforts to open up the decision-making structures of the FTAA negotiations and to influence the definition of the trade agreement's agenda.

To increase their influence in the negotiations, trade unions affiliated to the Inter-American Regional Labour Organization (ORIT) - the Western Hemispheric branch of the International Confederation of Free Trade Unions (ICFTU) - pressed for the formal incorporation of a Labour Forum as a consultative body into the FTAA negotiation governance structure (ORIT/ICFTU 1997). The Labour Forum process started in 1995 when ORIT began to organize parallel conferences to FTAA ministerial meetings and other summits. ${ }^{2}$ The lack of official recognition of the Labour Forum contrasted with the formal recognition of a Business Forum. This forum was set up by the largest companies in the region to identify its demands and issue recommendations to trade ministers in the definition of the agreement's agenda. ORIT's attempt to obtain official status for the Labour Forum was nonetheless never successful.

Simultaneous with the efforts to open up the decision-making structures of the FTAA negotiations, trade union organizations in the region also sought to democratize the trade process by participating in a series of official consultations set up as part of the formal negotiation structure of the FTAA. In particular, some unions participated in a series of consultations launched by the FTAA Committee of Government Representatives on the Participation of Civil Society (CGR) in 1998 and 2000.

The CGR nonetheless proved to be an inadequate vehicle for the inclusion of labour demands in the official negotiation process. Its function was merely to 'transmit' the views of civil society organizations to the FTAA trade ministers, 
rather than to create an adequate space for political deliberation about the agenda of the eventual trade agreement. The limited scope of the CGR reflected the reticence of some Latin American governments with regard to establishing any kind of supranational initiative that could eventually complicate the executive branches' control of the negotiation process (Botto and Tussie 2003: 43). Policy recommendations were submitted by trade unions and other social organizations via the Internet, to be incorporated as terms of reference in the negotiations. This input was not followed by any kind of feedback from government officials that could be sent to the trade unions and other organizations that formulated recommendations. This prevented a two-way political dialogue from taking place between trade ministers and trade unionists (ART 2003: 2).

Trade ministers also retained the discretionary power to filter out any submissions from civil society organizations that they considered 'inappropriate'. Anything that could politicize, and hence potentially obstruct or delay, the goal of market liberalization would count as an inappropriate submission. Governments specified that the CGR would accept only 'trade-related matters' presented in a 'constructive' manner. Issues such as human rights, gender, poverty and others, which are commonly treated by some officials as 'non-trade issues', were not brought into the trade discussions (Shamsie 2003: 16).

This led trade union organizations and other social organizations to reject this mechanism of participation as useless for influencing the negotiation process. It was claimed that the real function of the CGR was 'to keep up the appearance of dialogue' (ART 2003). Moreover, it became increasingly clear to the trade unions that the proposed form of participation for civil society was intended to furnish an exclusionary FTAA process with a veneer of democratic legitimacy.

In 2001 trade union organizations in the Americas stopped participating in official initiatives for the inclusion of civil society organizations. Instead, the unions affiliated to ORIT joined forces with other social organizations from the continent in an attempt to derail the FTAA process, as there now appeared to be no chance to 'reform' it in order to accommodate a developmental agenda. The outcomes of past labour mobilizations leading to the establishment of NAFTA's North American Agreement on Labour Cooperation (NAALC) and MERCOSUR's Socio-Labour Declaration demonstrated that the labour movement could not settle for institutional arrangements that effectively meant the cooptation of labour demands by installing weak institutional arrangements deprived of any enforcement power.

\section{Unification of the labour movement in the Americas}

A second practice adopted by the labour movement in the Americas in response to the FTAA process has been the closing of ranks between trade union organizations in the region. Important steps were taken in this respect with the creation of the Labour's Platform for the Americas (LPA) and with the Trade Union Confederation of the Americas (TUCA). Although the regional unification of the labour movement had begun to take place prior to the launch of the FTAA 
process, labour opposition to this trade integration project contributed significantly to the acceleration of labour convergence.

The main drive behind the unification process was undertaken in the framework of ORIT with the leadership of the Brazilian United Workers' Federation (CUT), the AFL-CIO from the US and the Canadian Labour Congress (CLC). A number of independent unions like the PIT-CNT from Uruguay, the Central of Argentine Workers (CTA), the CTC from Cuba and the CGT of Peru and Chile were also instrumental in mobilizing efforts towards union convergence around the FTAA project. The Labour Fora that were set up from 1995 as a venue to debate labour concerns regarding the FTAA project provided a space to develop a common position that could represent all of the participating trade unions in a united front. Efforts to unite trade unions under a common position rested on earlier initiatives of transnational labour solidarity, which provided a background of shared experiences and working links between unions. One important case was the solidarity between trade unions in the US, Canada, Mexico and some Central American and Caribbean countries as part of the anti-sweatshop movement that emerged in the 1980s (Armbruster-Sandoval 2005; Coronado and Staudt 2002; Quinteros 2000). Labour alliances prompted by the NAFTA process (Carr 1999; Compa 2001), MERCOSUR in the Southern Cone Union Coordination (CCSC), the Andean Labour Consultative Council (CCLA) of the Andean Community of Nations, the Central American and Caribbean Union Coordination (CCSCAC) and the Caribbean Congress on Labour (CCL) (ORIT/CIOSL 2006) were also part of this background.

Efforts to build a united labour strategy in the Americas had to overcome the North-South tensions that often characterize the international labour movement (Anner 2006). The current economic governance system gives capital the advantage of moving freely across borders, creating a system in which labour movements become subsumed in a logic of inter-state and/or inter-regional competition to attract investments. This situation undermines the potential for greater international labour solidarity. Furthermore, it exacerbates nationalism, xenophobia and cultural chauvinism. The breakdown of class compromise that followed the post-World War II era led to more rights for workers and better living conditions in Northern industrial countries. This resulted in Northern unions becoming increasingly defensive and centred on issues of wage and job security (Anner 2006). Workers on the other side of the globe, predominantly in Southern, less industrialized countries, have not achieved the same development and their unions focus instead on bread and butter issues while also seeking broader alliances with other social actors (Eder 2002: 167).

North-South divisions surfaced in debates about the inclusion of a 'social clause' in the WTO in relation to the creation of a system to enforce international labour standards. Regardless of the relative merits of this instrument, this labour agenda has been criticized as representing the priorities and demands of Northern unions exclusively (Anner 2006; Harrod and O'Brien 2002; Jakobsen 2001; Waterman 2001; van Roozendaal 2002).

Some of the tensions that characterize the international labour movement were also present in the unification process of the labour movement in the 
Americas. They are mainly reflected in the different approaches between unions in the North and the South to defining the challenges and responses of workers to the FTAA project. Northern unions sought to improve working conditions throughout the continent by prioritizing the inclusion of a 'social clause' at the core of the FTAA agreement. This would have affected the trade rights that signatory countries are given, by linking an FTAA with respect for a set of basic internationally recognized workers' rights in line with the 1998 ILO Declaration on Fundamental Principles and Rights at Work.

Latin American unions had a different understanding of the challenges posed by the FTAA project to workers. On the one hand, they tend to be sceptical about the potential (mis)use of 'social clauses' for protectionist reasons; namely, to defend job security in light of competition from Southern economies with cheaper labour costs. Such reluctance to include 'social clauses' in trade agreements is also shared by most governments in Latin America, which fear that they might be manipulated to restrict exports. As Elliott claims, 'the experience with American antidumping and countervailing duty policies certainly gives developing countries ample reason to be suspicious of potential new avenues for "contingent protection"' (2004: 648).

On the other hand, Latin American unions believe that an FTAA 'social clause' to safeguard basic labour rights was too narrow an approach to be able to address the deep developmental implications raised by the FTAA. Labour and social rights cannot be realized if the FTAA project has a negative impact on the availability and quality of employment (FLA 2005; ORIT/CIOSL 2006: 11). Social clauses in trade agreements cannot be separated from the broader struggles to modernize economic systems and the active participation of the state as a promoter of development (Godio 2003: 38). As Jakobsen from the Brazilian CUT puts it:

When it comes to the effects of globalization in the form of 'free trade', the restructuring of production, or the liberalization of investments, it is not sufficient to demand that the basic rights of workers are safeguarded. What is the good of guaranteeing the right to freely organize and bargain collectively, for example, after the jobs have been destroyed? For the workers of the South, it is fundamentally important that the international trade union agenda also includes unambiguous opposition to the neoliberal experiment and the discussion of alternatives that allow sustainable development with the generation of employment and income and the preservation of basic human and trade union rights.

(2001: 370)

This debate added to the increasing unity of the labour movement. Underlying existing political differences, the labour movement shared a commitment to preventing the FTAA from institutionalizing a trade governance model that made low wages and poor working conditions the main competitive advantages for attracting investment. In this respect, even if the 'social clause' was not a 
panacea for solving the problems of employment, wages and working conditions, it served as a meeting point around which diverse labour unions from the continent could begin to articulate a more elaborate labour perspective on a regional integration alternative to the FTAA model.

A historical breakthrough in hemispheric labour unity was reached in 2005 with the creation of 'Labour's Platform for the Americas' (CSA 2005). The LPA contains a proposal for alternative development for the Americas based on 'Decent Work for Sustainable Development'. It is the result of a 'democratic process of reflection, debate and consultation bringing together regional labour perspectives, researchers and representatives of other social sectors' (CSA 2005: 1). The LPA was publicly launched in the context of the Summit of the Americas of Mar del Plata in which employment was the central theme. At this meeting a coalition of governments led by the US tried to rescue the FTAA process from the terminal stagnation into which it had languished since 2003.

ORIT played the leading role in mobilizing unions into agreeing a common programmatic document like the LPA. Additionally, the document was supported by independent trade unions that were not affiliated to ORIT, as well as by the other main international labour organization in the region: the Latin American Confederation of Workers (CLAT) - the regional branch of the World Confederation of Labour (WCL). One of the greatest merits of the LPA is that its process of discussions incorporated unions with different ideological traditions. This factor contributed to the unity of the labour movement (Godio 2007: 103). The LPA represents an unprecedented accomplishment in efforts to reach political convergence between the main trade union organizations in the Americas. However, the LPA still remains an instrument of labour unity that is shared almost exclusively at the level of top representatives of trade unions.

Finally, important organizational changes were led by ORIT in its efforts to create a single international organization at the hemispheric level. Steps taken towards the unification of labour unions in the Americas are inscribed in a broader process of the international labour movement oriented to overcoming the divisions inherited from the Cold War years (Chaloult and Fernández 2001; Dagenais 2005: 3; Mazur 2000; Munck 2002; Waterman 2001). Such efforts to unite the international labour movement resulted in the establishment of the International Trade Union Confederation (ITUC) in November 2006 with the merging of some national trade unions and mainly the ICFTU/GU (Global Union) and WCL as the two major international trade union centres.

The political convergence mobilized by the LPA process, and the debate about the future of the labour movement of the Americas, were triggered by the creation of ITUC in a favourable context of left-of-centre governments coming to power in many Latin American countries (Wachendorfer 2007). This led to the creation of the Trade Union Confederation of the Americas (TUCA) in March 2008. As the regional branch of the ITUC, TUCA became the single labour organization in the Western Hemisphere representing 65 national organizations in 29 countries, affiliating more than 50 million workers. Its creation was made possible by the convergence of ORIT, CLAT and a series of independent 
unions that historically have refrained from any affiliation to international organizations (ORIT/ICFTU 1997).

Opposition to the corporate agenda contained in the FTAA project opened a political opportunity to accelerate ongoing unification processes, facilitating political and organizational convergence. The need to influence the FTAA process with a labour perspective and later the rejection of the FTAA altogether demanded cohesion and concerted action between the unions. Most importantly, opposition to the FTAA created conditions for the renewal of the labour movement with the struggle for 'sustainable development', a view which goes beyond the traditional demands of the labour union centred on wage and work conditions. The fact that it incorporated demands from other social movements and labour perspectives also creates a new context for the renewal of the labour movement. The connection of the trade unions to various social movements is addressed in the next section.

\section{Coalition building with other social organizations and movements}

The labour movement of the Americas has also engaged in a strategy of coalition building with a wide range of allied social organizations and movements in the hemisphere. In the short term, the value of this strategy rested on its potential to increase labour leverage vis-à-vis the trade negotiation processes by mobilizing a broad front with social movements to oppose the advancement of neoliberal trade integration initiatives in the region. However, in the long run the forging of enduring coalitions with different social forces allows the labour movement in the Americas (or at least parts of it) to begin renewing itself by expanding its superseded bases of representation of workers in light of ongoing transformations in the labour market.

Neoliberal globalization and regionalization have radically transformed the structure of the labour market in the Americas. The rise of informal work undermines the basis of representation of trade unions, since informal workers cannot enjoy basic rights such as freedom of association and collective bargaining. Informality also considerably weakens the power of unions to mobilize and organize workers at the grassroots levels, as well as contributing to fragmentation. There is also the challenge of organizing and representing workers in a growing tertiary service sector where they have fewer rights and little experience of unionization. All these factors pose the challenge of redefining the ways in which the labour movement represents workers (ORIT/CIOSL 2006: 9-10).

Post-Fordism has ended the traditional image of the working class as being made up of white, male blue-collar workers, but it has shifted social relations of production (Eder 2002: 167). Unions are slowly moving away from such a simple representation of existing members, altering their traditional image of the representation of workers, and displaying more readiness to include new forms of work (Harrod and O'Brien 2002; Waterman 2001). In so doing, they have begun to address wider social issues, such as development, gender and human rights (Muro and Themudo 2003: 57). 
As Muro and Themudo (2003: 57) claim, 'fighting for social justice objectives [trade unions] are forging new relations with "the poor" and those who defend their interests'. There is renewed energy to protest against current forms of globalization and it is widely acknowledged that trade union internationalism is central to that struggle. What else is central, however, is the seeking of alliances with civil society actors (Harrod and O'Brien 2002; Waterman and Willis 2001; Mazur 2000). The formation of coalitions with civil society is heralded by all authors as crucial for labour taking up new challenges and for reaching a wider audience (Waterman 2001; Lambert 2002). This has been reflected in the establishment of coalitions between trade unions and the so-called 'anti and/or alter-globalization' movements (ICFTU 2004).

The labour response to the advance of neoliberal trade projects in the Americas provided a political opportunity to forge such ties with other social forces. Some of these developments were discussed in the previous section. Yet the political representation of work does not take place exclusively at the level of inter-labour dialogue. As this section discusses, it is also manifested in the efforts of unions to establish close links with various other social organizations that represent a wide array of demands. Such demands include the need to recognize the gender perspective on work relations; and an environmental approach to production which transcends the logic of a development rooted in assumptions of industrialization and rationalism resulting from the particularly Western experience of modernity.

As with the other aspects of labour mobilization, the politics of coalition building with other social actors has also been largely facilitated by widespread social opposition to the trade integration initiatives being pursued during the 1990s. The NAFTA process led to unprecedented forms of transnational collaboration between trade unions of the US, Mexico and Canada, and gave rise to the Mexican Action Network on Free Trade (RMALC) in 1991. This coalition of trade unions, peasant and indigenous organizations, environmental groups, NGOs and researchers was united by a mission to analyse, contest and influence economic policy in general, and particularly trade policy in Mexico. The Alliance for Responsible Trade (ART) emerged in the US and Common Frontiers and the Réseau Québécois sur l'Intégration Continentale (RQIC) were set up in Canada.

Resistance to the FTAA process led to the hemispheric extension of such labour coalitions with other social forces under the umbrella of the Hemispheric Social Alliance (HSA). The main regional NGO networks working in the Americas on environment, human rights, gender, rural and indigenous issues were invited to participate in the Labour Forum hosted by the Brazilian CUT at Belo Horizonte in 1997. This meeting marked the beginning of a process of alignment of labour movements with a vast number of social organizations on the continent. This becomes explicit in the final declaration of this meeting where it gives its goal as working towards 'effective complementarity between the perspectives and action strategies of the trade union movement and those of other social movements' (Foro Nuestra América 1997). The HSA has emerged as a hemispheric 
transnational advocacy network linking trade unions and more than 50 large organizations and networks from throughout the Western Hemisphere, with the objective of generating a continental social agenda alternative to the 'free trade' agenda proposed in the FTAA project.

The creation of this multi-sectoral coalition fostered the formation of other nationwide multi-sectoral coalitions that became integrated in the HSA as national chapters of the alliance: the Brazilian Network for the People's Integration (REBRIP) in 1998; the Autoconvocatoria No al ALCA (later renamed the Movimiento Si de los Pueblos - MOSIP) in Argentina in which the CTA plays a pivotal role; the Colombian Network Against Free Trade (RECALCA); and less formally organized coalitions in Central America, Paraguay, Uruguay, Chile, Peru and (to a lesser extent) Bolivia. All these national coalitions are interconnected hemispherically as national nodes of the HSA, which has an executive secretariat located at RECALCA (previously it was hosted by RMALC and later by the Brazilian CUT and ORIT).

The space of intersectoral dialogue facilitated by the HSA produced a series of policy documents, 'Alternatives for the Americas'. These documents contain the basis of consensus reached between the many organizations and networks that participated in a continental debate about how regional integration should be approached in the Americas, as an alternative model to the neoliberal FTAA project. This social agenda of integration would later be taken by the Venezuelan government as the basis for the proposed Alternative for the Americas (ALBA) project and the Bolivian People's Trade Agreement (TCP) launched by Evo Morales in April 2006 (Saguier 2007).

In spite of the widespread optimism about alliance seeking and its positive potential for the labour movement, it remains questionable how successful unions really are in opening up to such alliances and what role they can play in a coalition of civil society actors (Waterman and Willis 2001: 306). It remains to be seen how far the involvement of unions in multi-sectoral coalitions like the HSA will go beyond its tactical value of increasing labour's influence in trade (or other) processes by building support among other social constituencies. The challenge of expanding traditional notions of work representation remains real, considering the existence of informal work and other unrepresented/invisible forms of labour.

\section{Spaces of participation at the grassroots level}

The labour movement in the Americas has also participated in and supported the creation of alternative democratic spaces to formulate and articulate its demands in relation to the FTAA process. Trade unions participated (along with the HSA) in the creation of the People's Summits process, the World Social Forum (WSF) and a Continental Campaign against the FTAA. These informal spaces became points of leverage that strengthened labour positions in denouncing the socially and democratically regressive FTAA project.

People's Summits, where the FTAA project featured as a key area of labour mobilization, were held in the context of the Summit of the Americas (Santiago 
in 1998, Quebec in 2001 and Mar del Plata in 2005) and FTAA trade ministerial meetings. The People's Summits provided a space where all trade union representatives and other social organizations could meet and exchange information, reach common positions and coordinate hemispheric-wide actions. A final declaration and plan of action were issued at the end of each summit with the conclusions of the event and workshops. The mobilizations that took place at the Buenos Aires People's Summit of 2001 (parallel to the FTAA Ministerial Meeting) pressured governments into the public release of the FTAA draft document which took place later that year.

Another important space for the participation of the labour movement from 2000 is the WSF. Since the first WSF in Porto Alegre, Brazil, there have been myriad versions of this forum, including regional versions in the Americas, Africa, Europe, Asia and North America, national fora and theme-based fora. The Americas Social Forum, held in Ecuador in 2003, was particularly important for mobilizing opposition to the FTAA at a time when it became clear that the trade negotiations had stagnated. Unlike the People's Summits, the WSF issues no final declaration aimed at representing the views and demands of all participants.

The choice of the spaces for labour participation at the grassroots level has also depended on changes in the political context in the region, as well as in the FTAA process. Since the start of FTAA negotiations in 1998, the engagement of trade unions with this process has prioritized efforts to influence negotiations and reform the trade agenda with a commitment to a labour clause. This strategy was abandoned in the aftermath of the Quebec Summit of the Americas in 2001. The shortcomings of earlier engagements with this process were evident from the reduced capacity of the labour movement to influence the terms of the negotiations. Growing opposition to neoliberal globalization in public opinion, as illustrated by the Quebec demonstrations, also contributed to a shift in the labour movement's approach to the FTAA process. The new strategy would aim to derail the FTAA process altogether.

In this context, the labour movement was accompanied by an initiative of the HSA and other social forces in Latin America critical of neoliberal policies to launch a Continental Campaign against the FTAA. Established and active social movement networks such as Jubilee South, Cry of the Excluded, Convergence of Movements of the Peoples of the Americas and others joined the campaign to oppose the FTAA. The main strategy of the Campaign was the organization and transnational coordination of a continent-wide popular consultation on the FTAA. This aimed at providing information on the consequences of the FTAA, in terms of fostering public debate on the links between trade policies and development. The popular consultations also sought to mobilize support behind governments to hold official plebiscites on the FTAA in every country as a precondition for eventual adherence to the agreement. The idea behind this was that if such official plebiscites were to take place, governments would not be able to rely on sufficient support to join the FTAA.

The national coordinating bodies of the Campaign organized a series of popular consultation initiatives between September 2002 and March 2003. The 
most successful of these experiences was conducted in Brazil between 1 and 7 September 2002, where more than 10 million people in 3,894 municipalities from across the country voted in a popular plebiscite on the FTAA. The results of this consultation showed that 98 per cent of the people that participated were opposed to the signing of the FTAA, and only 1 per cent supported it ('Dez milhões' 2002).

Another important initiative took place in Argentina, where between 20 and 26 November 2003 the Autoconvocatoria No al ALCA network organized a popular consultation on the FTAA, foreign debt and militarization. On this occasion, 2,252,358 people voted in 5,700 voting boxes placed in every province of the country (Berrón and Freire 2004: 301). The results of this consultation showed that 96 per cent of the people expressed their opposition to the FTAA. A second consultation was launched in July 2004 to pressure the government to hold an official referendum on the FTAA, although this did not succeed.

The experience of Paraguay was also relatively successful. With the leading role held by the Social Pastoral section of the Episcopal Conference of the Catholic Church, rural movements and organizations, and NGOs working mostly on human rights and the environment, a popular consultation was organized during 2003 in 17 districts around the country. Surpassing organizers' expectations, 162,676 people participated in this consultation. The Paraguayan campaign managed to introduce the FTAA as an issue of discussion in the press and in national debate. This is considered to be one of the most important achievements of the movement against the FTAA (Berrón and Freire 2004: 304).

In Mexico, a permanent consultation process was used from 12 October to 18 March 2003, in which two million people participated. However, 900,000 voted in favour of the FTAA. A consultation was launched in Ecuador by the Permanent Committee of Struggle against the FTAA on 9 October 2003, and the Uruguayan chapter of the HSA coordinated a consultation on 21 August 2003. Other initiatives were held with less significant repercussions in the US through an online consultation, a collection of signatures in Costa Rica, El Salvador and Honduras, and a public opinion survey in Peru and Canada.

The initiatives of grassroots participation discussed in this section, in which the labour movement was actively engaged, contributed to politicizing the FTAA process and agenda from 'outside' the formal institutional process. Advocacy efforts to open up the tightly controlled decision-making space of the FTAA negotiations were buttressed by grassroots opposition and an information campaign which successfully managed to give public visibility to this trade process. Likewise, it opened up the debate about the possible social and environmental implications of this trade agreement. In this respect, the contribution of the labour movement to the construction of grassroots spaces of participation is a means of building power 'from below'. This can be seen as a counter forum, shifting strategy in which trade unions increase their influence in trade policy process by investing in non-formal spaces. 


\section{Conclusion}

The labour movement in the Americas combined participation in formal spaces of participation in the negotiations, as well as informal grassroots spaces trying to gain leverage in relation to the negotiation process. It directed its advocacy efforts at attempts to open up trade decision-making spaces, in order to increase the representation of labour demands as part of emerging governance structures. The extent to which increasing participation in such formal trade processes leads to greater democratization of decision making depends on the capacity of the labour movement to resist being coopted. Engagement in trade policy processes is only desirable if the movement has a firm enough standing to be able to interpellate corporate power and also contribute to policy debates. Labour autonomy is also linked to having increased technical skills on trade issues, combined with strategic thinking to guide its interventions.

Labour unity is central to mobilizing responses in multiple institutional spaces with a common agenda. In this respect, cohesion is key to ensuring leverage in trade processes and offsetting the tensions between unions and sectors that can easily exacerbate divisions in the movement. In this regard, the steps taken to unite the labour movement in the Americas with the LPA and TUCA are important landmarks in efforts to build a united regional labour movement.

Nevertheless, convergence at the inter-union level is not sufficient to drive a deeper process of renewal of the labour movement. Autonomy of the labour movement also rests on the legitimacy of trade unions to act as organizations that represent workers' rights and demands. The rise of unemployed workers, illegal migration, tertiarization and non-unionized productive activities, among other features of the labour market, press trade unions to adapt its traditional representation of 'workers' - industrial/urban workers. Some of the coalitions established between trade unions and various social movements to mobilize against the FTAA project suggest a closer involvement of trade unions with other forms of work.

Opposition to the FTAA project created conditions for the viability of multisectoral coalitions as tactical responses for increasing leverage against this neoliberal trade initiative through mass mobilization and resistance. The challenge is to move forward in the political articulation of trade unions and other social forces beyond the requirements of changing conjunctures. The chances of expanding the social bases of representation of the labour movement rest on its increasing democratization in the light of greater plurality of workers and social demands. The construction of political alternatives to neoliberal integration schemes can only take place with the participation of a range of social forces that are critical of the exclusionary and environmentally destructive logic of modern industrial notions of 'development'. In this respect, the renewal of the labour movement depends on its incorporation of struggles for land distribution and environmental sustainability led by peasant movements and environmental groups, the acknowledgement of existing dynamics of inclusion/exclusion based on gender and ethnic origin, the ancestral plight of the indigenous movement for the control of natural resources, and political representation and cultural 
survival, among others. The renewal of the labour movement cannot disregard such emerging forces.

In so far as the labour movement increases its capacity to engage in trade policy processes, and mobilize as a united front with social bases of support beyond direct union affiliates, unions can make the most of the many sites of social and political articulation that have emerged in recent years on the 'outside' of formal political institutions. Combining strategies of mobilization in formal processes and in grassroots spaces like social summits, fora, people's tribunals, campaigns and so on, the labour movement opens a new landscape of political opportunities to influence and contest trade policy. Just as powerful governments and TNCs adopt 'forum-shifting' tactics, trade unions are beginning to mobilize at the multiple levels of trade governance involved in trade policy decisions. Alliances with other social groups that may have better access to policy processes become strategically important. Political cohesion and coordination between unions is needed, as well as strong links with skilled and resourceendowed NGOs and popular movements. They can all add to their specific form of influence, which includes: transferring resources and skills in trade matters, securing access to institutional spaces, sharing advocacy experience and contacts, and mobilizing mass-based street demonstrations, public events and popular education initiatives. These practices create new opportunities for gaining leverage in political processes for the labour movement.

The labour practices that were presented in this chapter as responses to the FTAA process are only points of departure in the much longer aim of reformulating a type of labour movement capable of addressing the challenges of workers' representation raised by an increasingly decentralized and concentrated productive system. The current global economic and financial crisis incorporates greater pressure on national economies to protect employment. In the past this has led to the rise of nationalistic and xenophobic tendencies among the labour movements. More than ever, the need to reinforce international solidarity is of central importance. This is necessary, not only to avoid the fragmentation of the labour movement, but most of all to continue with the construction of a global labour force capable of having leverage in the creation of future economic governance arrangements that invariably affect the nature and conditions of work.

The intensity and depth of the experience of neoliberal trade projects undertaken in the Americas region provide a case study for many of the dynamics that drive neoliberal globalization. In particular, the labour practices adopted in this continent to resist (but also to facilitate) 'free trade' projects illuminate some of the challenges and avenues that the labour movement will have to take in order to realize its aspiration of seeing the workers of the world unite.

\section{Notes}

1 The 'Global-Local' Research Programme at the Institute of Development Studies (IDS), University of Sussex, provided financial support for this research. I would like to thank particularly John Gaventa and Rajesh Tandon. 
2 The first of these Labour Summits was held in Denver (1995), followed by Cartagena (1996), Belo Horizonte (1997) and the MERCOSUR presidential summit (1996).

\section{References}

Anderson, S. and Arruda, M. (2002) 'Another Integration Is Possible: Sovereignty Yes, FTAA No', Washington, DC, and Rio de Janeiro: Institute for Policy Studies/Institute of Policy Alternatives for the Southern Cone of Latin America. Online. Available www.tni.org/article/another-integration-possible-sovereignty-yes-ftaa-no (accessed 4 March 2010).

Anner, M. (2006) 'Paradox of Labour Transnationalism: Trade Union Campaigns for Labour Standards in International Institutions', in C. Phelan (ed.) The Future of Organised Labour: Global Perspectives, Bern, Switzerland: Peter Lang AG: 63-90.

Appelbaum, R. P. (2005) 'Fighting Sweatshops: Problems of Enforcing Global Labor Standards', in R. P. Appelbaum and W. Robinson (eds) Critical Globalization Studies, Milton Park: Routledge: 369-378.

Armbruster-Sandoval, R. (2005) Globalization and Cross-border Labor Solidarity in the Americas: The Anti-sweatshop Movement and the Struggle for Social Justice, Abingdon: Routledge.

ART (2003) 'Back to Miami: A History of Citizens' Events Parallel to the Official FTAA Meetings'. Online. Available www.nisgua.org/themes_campaigns/trade_development/ ftaa/back_miami.pdf (accessed 4 March 2010).

Barenberg, M. and Evans, P. (2004) 'The FTAA's Impact on Democratic Governance', in A. Estevadeordal, D. Rodrik, A. M. Taylor and A. Velasco (eds) Integrating the Americas: FTAA and Beyond, Harvard, Mass.: Harvard University Press: 755-789.

Berrón, G. and Freire, R. (2004) 'Los movimientos sociales del Cono Sur contra el mal llamado "libre comercio", Revista OSAL - Observatorio Social de América Latina, 5(13): 296-306.

Botto, M. (ed.) (2007) Saber y política en América Latina: el uso del conocimiento en las negociaciones comerciales internacionales, Buenos Aires: Prometeo Libros.

Botto, M. and Tussie, D. (2003) 'La internacionalización de la agenda de participación en el debate regional', in D. Tussie and M. Botto (eds) El ALCA y las cumbres de las Américas: una nueva relación público-privada?, Buenos Aires: Editorial Biblos: $27-46$.

Carr, B. (1999) 'Globalization from Below: Labour Internationalism under NAFTA', International Journal of Social Science, 51(159): 41-59.

Chaloult, Y. and Fernández, W. (2001) 'A Alca e as novas alianças sindicais Norte-Sul', Revista Brasileira de Politica Internacional, 44(2): 168-185.

Compa, L. (2001) 'NAFTA's Labor Side Agreement and International Labor Solidarity', Antipode, 451-467.

Coronado, I. and Staudt, K. (2002) Fronteras No Mas. Toward Social Justice at the USMexico Border, London: Palgrave.

CSA (2005) 'Labour's Platform for the Americas', Confederación Sindical de Trabajadores y Trabajadoras de las Americas documents. Online. Available HTTP: www. csa-csi.org/component/option,com_docman/task,doc_download/gid,21/Itemid,181/ (accessed 4 March 2010).

Dagenais, V. (2005) 'Les retombées de la création d'une nouvelle organisation syndicale internationale sur le mouvement syndical dans les Amériques', Series La Chronique des Amériques No. 08, Université du Québec à Montréal, Montreal, Canada. Online. 
Available www.ieim.uqam.ca/IMG/pdf/Chro_0508_CISL.pdf (accessed 4 March 2010).

'Dez milhões contra a ALCA', Jornal do Brasil (18 September 2002).

Eder, M. (2002) 'The Constraints on Labour Internationalism: Contradictions and Prospects', in J. Harrod and R. O'Brien (eds) Global Unions? Theory and Strategies of Organized Labour in the Global Political Economy, New York: Routledge: 167-184.

Elliott, K. A. (2004) 'Labor Standards and the FTAA', in A. Estevadeordal, D. Rodrik, A. M. Taylor and A. Velasco (eds) Integrating the Americas: FTAA and Beyond, Cambridge, Mass.: Harvard University Press: 641-672.

Estay, J. and Sánchez, G. (eds) (2005) El ALCA y sus peligros para América Latina, Buenos Aires: Consejo Latinoamericano de Ciencias Sociales.

FLA (2005) El futuro del movimiento sindical, Caracas: Fundación Luis Anderson.

Foro Nuestra América (1997) 'Construyendo la Alianza Social Continental frente al Libre Comercio'. Online. Available www.developmentgap.org/americas/Construyendo_la Alianza_Social_Continental_frente_al_libre_comercio.htm (accessed 4 March 2010).

Gill, S. (2002) 'Constitutionalizing Inequality and the Clash of Globalizations', International Studies Association, 4(3): 47-65.

Godio, J. (2003) 'Sindicalismo sociopolítico. Bases y estrategias para la unidad y renovación Sindical', Oficina Internacional del Trabajo, ILO, Santiago, Chile: 1-43. Online. Available www.oitchile.cl/pdf/publicaciones/ser/ser005.pdf (accessed 4 March 2010).

(2007) 'La importancia estratégica de la Plataforma Laboral de las Américas', Nueva Sociedad, 211: 98-108.

Harrod, J. and O'Brien, R. (2002) Global Unions? Theory and Strategies of Organized Labour in the Global Political Economy, New York: Routledge.

Herod, A. (2002) 'Organising Globally, Organising Locally: Union Spatial Strategy in a Global Economy', in J. Harrod and R. O'Brien (eds) Global Unions? Theory and Strategies of Organized Labour in the Global Political Economy, New York: Routledge: 83-99.

Hillebrand, B. (2003) 'Más allá del comercio: los problemas de fondo del ALCA', Estudios sobre el ALCA, No. 17, Santiago: Friedrich Ebert Stiftung. Online. Available http://library.fes.de/pdf-files/bueros/chile/01900.pdf (accessed 4 March 2010).

Hyman, R. (2004) 'The Future of Trade Unions', in A. Verma and T. A. Kochan (eds) Unions in the 21st Century, Basingstoke: Palgrave Macmillan: 17-29.

Icaza Garza, R., Newell, P. and Saguier, M. I. (2010) 'Citizenship and Trade Governance in the Americas', in J. Gaventa, and R. Tandon (eds) Citizen Engagements in a Globalising World, London: Zed Books.

ICFTU (2004) 'Globalising Solidarity - Building a Global Union Movement for the Future', International Confederations of Free Trade Unions XVIII World Congress, 5-10 December. Online. Available www.icftu.org/www/pdf/Globalising\%20Solidarity. pdf (accessed 4 March 2010).

Jakobsen, K. A. (2001) 'Rethinking the International Confederation of Free Trade Unions and its Inter-American Regional Organisation', Antipode, 33(3): 363-383.

Lambert, R. (2002) 'Labour Movement Renewal in the Era of Globalization: Union Responses in the South', in J. Harrod and R. O'Brien (eds) Global Unions? Theory and Strategies of Organized Labour in the Global Political Economy, New York: Routledge: 185-203.

Mazur, J. (2000) 'Labour’s New Internationalism', Foreign Affairs, 79(1): 79-93.

Munck, R. (2002) Globalisation and Labour, London: Zed Books.

Muro, D. and Themudo, N. (2003) 'Trade Unions in a Changing World: Challenges and 
Opportunities of Transnationalization', J. D. Clark (ed.) Globalizing Civil Engagement, London: Earthscan Publications: 45-65.

O'Brien, R., Goetz, A. M., Scholte, J. A. and Williams, M. (eds) (2000) Contesting Global Governance: Multilateral Institutions and Global Social Movements, Cambridge and New York: Cambridge University Press.

ORIT/CIOSL (2006) 'Integración, libre comercio y la acción sindical en América Latina y el Caribe', Libres Sao Paulo, Brasil: Organización Regional Interamericana de Trabajadores de la Confederación Internacional de las Organizaciones Sindicales: 1-100. Online. Available http:/gurn.info/en/topics/bilateral-and-regional-trade-agreements/ bilateral-and-regional-trade-agreements-1/trade-union-comments/icftu-oritintegracion-libre-comercio-y-la-accion-sindical-en-america-latina-y-caribe-feb-06 (accessed 4 March 2010).

ORIT/ICFTU (1997) 'Declaration of the Workers of the Americas', III Trade Union Summit, Belo Horizonte, Brazil, 16 May. Online. Available www.cioslorit.org (accessed 31 March 2008).

Quinteros, C. (2000) 'Acciones y actores no sindicales, para causas sindicales', Nueva Sociedad, 169: 162-176.

Ross, R. and Chan, A. (2002) 'From North-South to South-South: The True Face of Global Competition', Foreign Affairs, 81(5): 8-13.

Saguier, M. I. (2007) 'The Hemispheric Social Alliance and the Free Trade Area of the Americas Process: The Challenges and Opportunities of Transnational Coalitions against Neo-liberalism', Globalizations, 4(2): 251-265.

Sangmeister, H. and Taalouch, K. (2003) ‘¿Quiénes pueden beneficiarse del ALCA?', Estudios sobre el ALCA No. 18, Santiago: Friedrich Ebert Stiftung. Online. Available http://library.fes.de/pdf-files/bueros/chile/01901.pdf (accessed 4 March 2010).

Shamsie, Y. (2003) 'Mutual Misgivings: Civil Society Inclusion in the Americas', Publication of North-South Institute, Ottawa, Canada. Online. Available www.un-ngls.org/ orf/cso/mutual_misgivings.pdf (accessed 4 March 2010).

Stevis, D. (2002) 'Unions, Capitals and States: Competing (Inter-)Nationalisms in North American and European Integration', in J. Harrod and R. O'Brien (eds) Global Unions? Theory and Strategies of Organized Labour in the Global Political Economy, New York: Routledge: 130-150.

Van Liemt, G. (1999) 'International Trade and Workers' Rights: More than a Conditional Link?', in B. Hocking and S. McGuire (eds) Trade Politics: International, Domestic and Regional Perspectives, Abingdon: Routledge: 238-248.

Van Roozendaal, G. (2002) Trade Unions and Global Governance: The Debate on a Social Clause, Abingdon: Routledge.

Wachendorfer, A. (2007) ‘Hacia una nueva arquitectura sindical en América Latina?’, Nueva Sociedad, 211: 32-49.

Waterman, P. (2001) 'Trade Union Internationalism in the Age of Seattle', Antipode, 33(3): 312-336.

Waterman, P. and Willis, J. (2001) 'Space, Place and New Labour Internationalisms: Beyond the Fragments?', Antipode, 33(3): 305-311. 


\section{Index}

Page numbers in italic refer to tables. Page numbers in bold refer to figures.

accountability: and advocacy 5, 129, 130, 131, 133; and CSOs 23, 26, 159; and international governance 3; and third sector 63

accountability politics 133,143

activists 5, 6, 7, 62, 67, 99

adaptation, to Europeanization 74,82 , $84-5,87$

advocacy domain and public sector 58 , $59-62$

advocacy groups: in Africa 153, 154, 156,

157; in the Americas 190; in East Asia

129-30, 137, 139-41, 142; in the EU

55, 56; in the Middle East 175; as NSAs 74

Advocates' Coalition for Development and Environment (ACODE) 154

AEK (Alfabetatze Euskalduntze

Koordinakundea) 118, 119

affiliation potential, NSAs and EU institutions 81-2

Africa: regional governance 148-62; regional identity 33,44

African Network of AIDS Service

Organizations (SANSO) 155-6

aggregation of preferences 53-4

Alliance for Middle East Peace 174

Alliance for Responsible Trade (ART) 189

alter-globalism 16, 189

Alternative Chamber of Agriculture (EHLG) 120-1

Americas, transnational labour mobilization 181-94

ANGOC (Asian NGO Coalition for

Agrarian Reform and Rural

Development) 137-41, 142, 143

anti-discrimination 52, 101, 102 anti-globalization movement 157, 189

anti-nationalism 103

Anti-Privatization Forum (APF) 157, 158

Aquitaine-Euskadi Common Fund 113, 118,120

Arab civil society 172

Arab Integrated Water Resources

Management Network (AWARENET) 174

Arab League 171, 173, 174

Arab NGOs Network for Development (ANND) 175

Arab state system 167, 172

ARIPTIC project 120

Arizmendi Koop 120

Asia-Europe Meeting (ASEM) 138

Asia-Europe People's Forum (AEPF) 138

Asia Pacific Human Rights Network 138, 141

Asia Pacific Women, Law and

Development (APWLD) 137, 138, 141

Asia Pacific Women's Watch 138

Asian Development Bank (ADB) 140

Asian Development Forum (ADF) 140

Association of South-East Asian Nations

(ASEAN) 130, 135

associative networks 112, 118

authoritarian states, Middle East 167, 168, 173,177

Barcelona process 171

Basque Country 107-22

Basque identity 117-22

Basque language 109, 111, 112, 117-19

Basque nationalists 80, 109, 113, 114-15, 116, 117

Bayonne-San Sebastián Eurocity 113

Beck, U. 23 
Beijing Platform for Action (BPFA) 138, 154

boomerang effect 134, 143

border-transcending relationships 108, 122

borders, and identity 40,42

Bosnia and Herzegovina (B\&H): collective identity 102; and European integration 100; and international funding 97-8; non-governmental organizations 92-103; obstacles to development of civil society 101-2; social movements 96

Brazilian United Workers' Federation (CUT) 185, 186, 189

briefcase NGOs 152, 159, 160

bürgerlichegesellschaft 17, 18

Catholic Church, Basque Country 110 citizen groups 58, 59, 61-2, 95

citizen participation $31,82,156$

citizenship 18, 92, 94, 95

civic collective action 61

civil services $49,51,56$

civil society: and citizenship 18; coalitions 58, 59, 61, 62, 64-5; definition 4-5, 16, 149-50, 166-7; democratization of global public space 15-28; in East Asia 129, 134-6; and economic development 129, 134; in the European Union 26-7, 49-67; and globalization 25, 129 , 168-9, 172; and governance 5-6, 22, 52 ; legitimating regional governance 151, 156-7, 161; manipulating regional governance 151, 159-60; as market 3, 18,19 ; in the Middle East 166-77; mobilizations 109-11; obstacles to development of 101-2; as partner in regional governance $151,152-6,161$; and policy making 50-4, 66, 154; and politics 24, 28, 31, 57, 58, 73, 87; and public sector 52-4, 57-9, 65-6; and regional governance 148-62, 166-77; resisting regional governance 151 , 157-9; role of 26-7, 43-4; and the state 19-20, 150, 152; and trade unions, Americas 188-90; in a transitional country 94-5; as Western concept 129 , 134

civil society groups $49-67$

civil society organizations (CSOs) 149-50; and profit/political gain 159-60; and regional governance 151-2, 153, 158, 161-2; and social issues 174-5; and trade negotiation 183-4 civilizations 38,39

coalitions: in the Americas 188-90, 193; in East Asia 129-44; in the EU 58, 59, 61,

62, 64-5; NSAs and EU institutions 81 coercion $22,23,25$

collective action $24,61,80,81,111,132$, 133

collective actors $34,36,38,43$

collective identity $31-45$; in Basque

Country 117; in Bosnia and Herzegovina

102; vs social identity $34-8$

Committee of Government Representatives on the Participation of Civil Society (CGR) 183-4

Common Frontiers 189

Common Market for Eastern and Southern Africa (COMESA) 148, 153

communication, and identity 35-6

communism, in Europe 94-5

communitarian socializations $37,38-40$

community, belonging to $37,39,42$

competitive regionalism 85

compliance: and accountability 3,130 ; voluntary 23

consciousness vs rationality $36-8$

cooperative federalism 85

cooperatives $112,119,120$

corporations $17-18$

cosmopolitan democracy 21, 22

cosmopolitan identity 38

counter-elites 9,92

crisis of the state 22,25

cross-border cooperation, Basque Country 107-22

CSOs see civil society organizations

degree of fit, adaptation to EU 85

democratic deficit 26, 73, 84, 87, 152

democratic legitimacy 5, 6, 17, 18, 19, 21

democratic transition 95

democratization: civil society as locus of 95, 102, 103; global 169; of global public space 15-28; in the Middle East $166,167,168-70,176$

demos 32, 92, 101-3

donor funds, Africa 161

East African Communities' Organization for Management of Lake Victoria Resources (ECOVIC) 153, 154, 161

East African Community (EAC) 148, 153, 154, 156

East African Legislative Assembly (EALA) 153 
East African Sustainability Watch Network (EASWN) 156

East Asia 129-44

East Asian Summit 130

Eastern Africa 148-62

Eastern African Sub-regional Initiative for the Advancement of Women (EASSI) 154

eco-localism 110

economic actors $23,24,50$

economic development: and civil society 129,134

economic globalization 64, 149

Economic Partnership Agreements (EPAs) 181

EHNE (Euskal Herriko Nekezarien Elkartasuna) 121

ELB Union (Euskal Herriko Laborarien Sindikata) 111, 121

electoral practices, Middle East 169

elites: NGO 7, 80, 158; NSA 81, 82, 87; political 92, 158, 159, 160; state 166, 168

Elkarri 110

emerging economies 181

empowerment of civil society $95,97,98$, 102

enforcement, and accountability 3, 130

entrepreneurship in EU institutions 100

entry requirements, to groups 39,40

environmental issues: Basque Country

110; East Asia 136, 137-8; Eastern and

Southern Africa 153, 154, 156; Middle East 174

ETA (Euskadi eta Askatasuna, Basque

Homeland and Freedom) 109, 110

ethnic and cultural identities 32-3, 38

ethnicity 93-4

ethnicization 94

ethno-nationalism 94, 101, 102, 107

ethnos 32, 92, 101-3

EU Framework Programme (FP) 79

Euro-enthusiasts 114, 115

Euro-pragmatists 114, 115

Euro-sceptics 114

Eurogroups 77

European Commission 31, 49-67, 79, 81, 103

European Economic and Social Committee (EESC) 43, 44, 74

European identity 42, 44, 45, 100, 101

European integration: and Basque Country 107-22; and Bosnia and Herzegovina 100; and Europeanization 75, 86
European learning 82-3

European Neighbourhood Policy 27

European NGO Confederation for Relief and Development (CONCORD) 83

European standard 101

European Union: and the Balkans 92-103; and Basque nationalists 114-15; constitutionalization process 32,84 ; decision making, access to 78-9; governance and NSAs 78, 80; governance system 31-2, 77, 86; membership 78, 92, 101

European values 100, 101

Europeanization: adaptation to 74,82 , 84-5, 87; and cross-border cooperation, Basque Country 107-22; definition 75-6; and globalization 75; and localization 92-103; of non-state actors 73-87; through socialization $82-3$ euskera 118, 119

expertise, and NSAs 79

external interventionism 98

farmers: mobilization, Basque Country 111, 119, 120-1; rights, Eastern Africa 154

federalism 85

foreign direct investment (FDI) 181

Forum-Asia 136-41, 142, 143

forum shifting 181-2

Foucault, M. 18, 27, 28

free civil society, Arab 172

free trade agenda 186, 190, 191, 194

Free Trade Agreements (FTAs) 181

Free Trade Area of the Americas (FTAA) 181-94

functional interest groups 74

gatekeepers $77,78,81,84$

gender issues 51, 56, 154, 173, 189

Gesto por la paz 110

global citizenship 23

global civil society $16,22,129$

global democratic institutions 22

global democratization 169

global economic crisis 130, 194

global governance 3, 22-3

global identity 37

global public space 15-28

globalization: and civil society 25,129 , 168-9, 172; and Europeanization 75; and free trade 186, 189; and governance 2,3 ; and the state 4,5 governance: and civil society $5-6,22,52$; 
contexts 2-3; in East Asia 129-44; effectiveness of 3; failure in 1; global 3, 22-3; and government 1-2, 22, 151; legitimacy of 3-4

government: definition of 1 ; and governance 1-2, 22, 151; and NGOs, East Asia 135

grassroots action networks, East Asia 140 grassroots participation, Americas 190-2, 194

Greater Arab Free Trade Area 171 group identity 81,82

Habermas, J. 19, 32

Hamas 176

hard conditionality 100

Hegel, G. 16-17

hemispheric labour unity 182, 183, 187

Hemispheric Social Alliance (HSA) 189-90, 191

Hezbollah 176

Hezkuntek association 120

HIV/AIDS organizations 155-6, 157, 173, 174

horizontal dynamics, and identity 33,36 , $38,39,42,45$

human rights: Africa 158, 160, 168; East Asia 135, 136, 138, 140-1, 143;

European Union 94, 101, 115; Middle

East 168, 173, 175, 176, 177

hybrid NGOs 97

identity $31-45$; definition $34-6$

identity construction: and civil society 43 , 44; ideal types of 39-40, 41; at macroregional level 40-4; regional identity 33 , 35 ; and social identity 37 ; vertical and horizontal dynamics of 36,38

ikastola 118, 119

inclusive identity 45

individual rights and freedoms 92, 103

informal work 188

information: and advocacy networks 133 , 142; and NSAs 79; and policy making $50-1,56,58,67$

Institut Supérieur de Formation Permanente (INSUP) 120

institutional asymmetry, and cross-border relations $115-17$

institutional change $82,84-6$

institutional design, and cross-border collaboration 113-14

institutionalization: of civil society 54,66 ; and French Basque Country 111,
116-17, 118-19; of social movements $60-1,64$

Inter-American Regional Labour

Organization (ORIT) 183, 184, 187

inter-network tension 142

interest groups see non-state actors

interest mediation 85

International Forum on Capacity Building (IFCB) 140

international funding, Bosnia and Herzegovina 97-8

international governance 2-3

international identity 34

international labour movement 181, 182, $185-6,187$

international non-governmental organizations (INGOs) 97, 99, 175

international organizations 138, 139, 142, 143

International Trade Union Confederation (ITUC) 187

internet, role of $2,61,135,185$

INTERREG programmes 113, 120

intra-civil society rivalry $161-2$

Islamic civil society 166, 170, 172, 176

isomorphism 84-5

Israeli civil society 172

Israel-Palestine Peace NGO Forum 174

jihadists 166

justification, and accountability 130

knowledge, and NSAs 79

Labour Forum 183, 189

labour market, the Americas 188

labour movement: the Americas 181-94; and social movements 188-90; unification of in the Americas 184-8, 193-4

labour rights 186, 193

Labour's Platform for the Americas (LPA) 184, 187, 193

Lake Victoria Basin Commission (LVBC) 153,156

Lake Victoria Fisheries Organization (LVFO) 153-4

Latin America: governments and trade negotiations 184, 186; regional identity 33,44

Latin American Confederation of Workers (CLAT) 187

Leaken Conference (2001) 75

learning, and Europeanization 82-3 
leverage politics 133,143

Lisbon Treaty 75, 84

lobbying: Africa 153, 154, 155, 162; East

Asia 132-3, 139, 143; European Union

26, 27, 78, 79; Middle East 173, 175, 177

local NGOs 97, 99

localization and Europeanization 92-103

Locke, J. 4, 16

low associative density 95

marginalized groups, East Asia 134, 135

market liberalization 184

Marx, K. 18

media, as socializing agent $42-3$

Mediterranean Arab Free Trade Agreement 171

MERCOSUR's Socio-Labour Declaration 184

meta-power game of global governance 23

Mexican Action Network on Free Trade (RMALC) 189

Middle East, civil society $166-77$; history 171-2

minority nationalist parties 114

mobilization: of civil society 109-11; of

NSAs, and Europeanization 80-1, 82

models in Western political thought 16-20

moral authority 23

Mukhabarat 171

multipliers 103

Muslim Brotherhood 172, 176

Mwelekeo wa NGO (MWENGO) 157

My Own NGOs (MONGOs) 152, 160

narratives of Europe 100-3

nation-building, Basque Country 114

nation-states 151

National Association of Professional

Environmentalists (NAPE) 156

national-territorial states $20-5$

nationalism 92, 93, 114-15

nationalist movements 109

neo-institutionalism 77-8

neo-patrimonial regimes 159

neoliberal globalization 149, 182, 188,

189, 191, 194

neoliberal policies 64, 191

neoliberal trade projects $188,189,193$, 194

networks, transnational 129, 131-4, 136-44

New Public Management 66

New Regionalism Approach (NRA) 149
NGOs see non-governmental organizations non-economic NSAs 85

non-governmental organizations (NGOs)

5-7, 21, 26, 56, 58; in Africa 152; in

Bosnia and Herzegovina 92-103;

definition 96; in East Asia 129-44; as

employers 99, 102; and EU policy 79;

and local population 98-9; in the Middle

East 171, 174-5; as non-state actors

74-5; and the state 97

non-state actors (NSAs): access to EU

decision making 78-9; and control of

resources 78-81; definition 74-5; and

EU governance 78; and European policy

making 74-5; Europeanization of

73-87; experts 79; non-economic 85; and political liberalization 170; and the

state 133,151

non-state interest mediation 85

normative power: European Union 94, 101; and networks 133

North American Agreement on Labour

Cooperation (NAALC) 184

North American Free Trade Area

(NAFTA) 149, 184, 189

NSAs see non-state actors

Open Method of Coordination (OMC) 83

openness, of groups 40, 42

Organization of Arab Petroleum-Exporting Countries (OAPEC) 171

Organization of Petroleum-Exporting Countries (OPEC) 171

Organization for Security and Cooperation in Europe (OSCE) 96

organized civil society 49-67

Organization of the Islamic Conference 171

Osienala Friends of Lake Victoria 153, 161

output legitimacy 26,27

Palestine 168, 173-4

Palestine Liberation Organization (PLO) 172, 173

Palestinian civil society 172

pan-Arabism 172, 173

Pan-Pacific and South-East Asian

Women's Association (PPSEAWA)

137,141

parallel summitry 133,139

path dependency model 85

patrimonialism 159

peace movements 109-10

People's Summits 190-1 
peripheral Europeans 101

policy learning 50-1

policy making: and civil society $50-4,66$, 154

policy reform, and CSOs 152

political identity 34

political liberalization 170

political protest 59,60

political representation 49-67, 54-7

politicizers 131

politics, and civil society $24,28,31,57$, $58,73,87$

popular mobilization 152

post-national space in transition 20-6, 28

post-Westphalian regions 166

power, and civil society $23,24,25$

pragmatic workers 98-9

preference aggregation 53-4

problem-solving NGOs 152, 159

promotional groups, as NSAs 74

propaganda 159

protest actions 59, 60, 109

public interest groups (PIGs) 26, 27, 52,

$56,58,62$

public sector: and advocacy domain 58,

59-62; and representation 54-7

public will 24, 25

publizität 18

rational action theory 86

rational choice institutionalism 78

rationality $36-8$

regional activism 131, 143

regional governance $3,148-62,166-77$

regional identity $33,42,45$

regional integration $31,32,34-5,42,44$

regional networking $168,175-6,177$

regional NGOs 135-6

regional summitry 138

regionalism 85; and East Asia 130-1, 141, 143-4; and the Middle East 168, 170-1 regionalization $149,166,173,188$

rent-seeking NGOs 159, 160

representation 54-7, 67

representational civil society 57

Réseau Québécois sur l'Intégration

Continentale (RQIC) 189

resource circulation 82

resource dependencies 86

Resource-Dependency Approach (RDA) $78-81$

resource mobilization theories 109

rights-demanding practices, labour movement 182
Rosenau, J. 1-2

SADC Council of Non-Governmental

Organizations (SADC-CNGO) 155

second modernity 20,25

sectoral organizations 74

self-organization 92, 95

self-understanding 35,36

semi-governmental organizations (SGOs)

159

separatist movements $31-2$

service delivery sector 58, 63-4, 153, 159

sexual minority issues 175

Single European Act of 198774

social capital 53, 111, 112

social clauses in trade agreements 185,186

social contracts 19,24

social and economic justice, in Africa

152-60

social economy, Basque Country 111-12

social identity $31-45$; vs collective identity 34-6

social interaction 37,39

social movements: Basque Country

110-11, 119; Bosnia and Herzegovina

96; European Union 58, 59-61, 62, 64,

74; and trade unions, the Americas

188-90, 191, 193

social partners 74

social welfare, Middle East 174-5

socialization, and Europeanization 82-3

socializing agents $42-3,87,131$

sociedades laborales 112

societal identity 39

societal socializations $37,38-40$

sociological institutionalism 84

soft conditionality 100

solidarity 41

Southern Africa 148-62

Southern African Centre for Economic

Justice (SACEJ) 157

Southern African Development

Community (SADC) 148, 153, 154-6,

157, 158, 162

Southern African Peoples' Solidarity

Network (SAPSN) 157-8

Southern African Research and

Development Centre (SARDC) 155

Southern African Social Forum 162

Southern African Trade Unions

Co-ordinating Council (SATUCC)

156-7

South-South relations 181

spaces of participation 190-2 


\section{Index}

Spain, regionalism 85

spontaneous dynamics of interactions 42

state, the 19-20, 24, 25

state actors $21,50,151,152,154,156$

state intervention 97

states: formation of $31-2$; role of $133-4,143$

structural Europeanization 100

super-national political spaces 21,22

supra-national institutions 66

supra-national platforms of cooperation 77 , 81

supra-national societies 31-45

sustainable development, in Africa 152-60

symbolic politics $133,142-3$

symbolic resources 81,82

terrorism 109, 113, 115, 138, 175, 176

Thessaloniki European Council 92

thick learning 83

thin learning 83

third sector 63-4; associations 58; cross-

border relations and Basque identity

117-22; mobilizations, Basque Country

107-22; organizations 24,63

trade ministers 184

trade negotiation processes $183-4,191$

trade policy 181

Trade Union Confederation of the

Americas (TUCA) 184, 187, 193

trade union internationalism 189

trade unions 181, 182, 183, 184-8, 193

transitional countries: and civil society 94-5

transnational advocacy networks 129 , $131-4,137$

transnational collaboration between trade unions 189

transnational identity 107

transnational labour mobilization 181-94

transnational mobilizations 122

transnational movements 21, 133

transnational networks: East Asia 136-41;

Middle East 166 transnational relationships 107-8

transnationalism: Middle East 170-1, 177; through technology 129-30

transparency, and accountability 3, 63, 130

Treatment Action Campaign (TAC) 157

Treaty of Bayonne 114

UN Conference on Environment and Development (UNCED) 140

UN Economic and Social Council (ECOSOC) 139

unification of labour movement, the Americas 184-8, 193-4

universalism 95, 97, 103

Vanhanen's index on democracy 169

venue shopping 53, 60

vertical dynamics, and identity $33,36,38$, 39

violence, political 109-10

voluntary sector 64

volunteerism 99

welfare providers 131,142

welfare state 64

Western modernity 15, 16, 20

Western political thought, models in 16-20, 150

Westphalian system 21, 59, 177

Wildlife and Environment Society of South Africa (WESSA) 154

women's movements 112, 132, 137, 138, 142,154

workers' cooperatives $112,119,120$

workers' rights 186, 193

World Bank 140

World Social Forum (WSF) 190, 191

World Trade Organization (WTO) 181, 185

zakat 172

Zimbabwe Coalition on Debt and Development (ZIMCODD) 158 